INTER NATIONAL MONETARY FUND
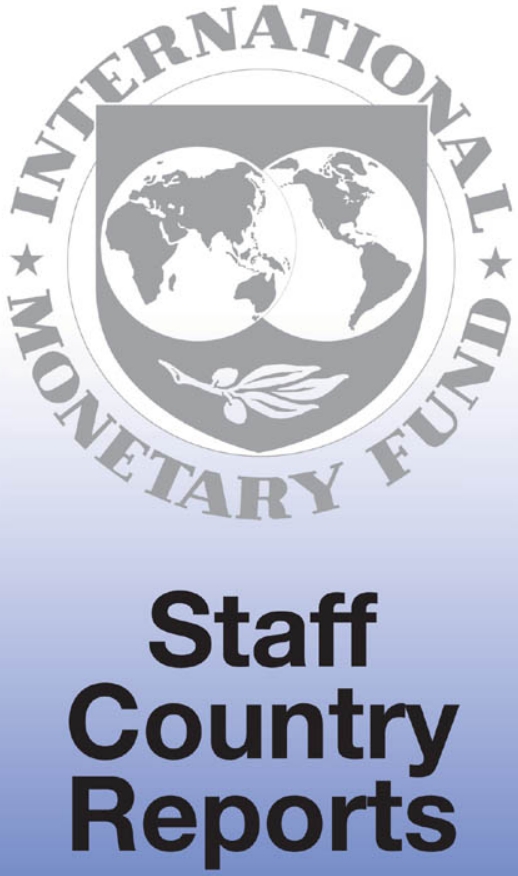


\section{Ghana: Selected Issues}

This Selected Issues report on Ghana was prepared by a staff team of the International Monetary Fund as background documentation for the periodic consultation with this member country. As such, the views expressed in this document are those of the staff team and do not necessarily reflect the views of the Government of Ghana or the Executive Board of the IMF.

Copies of this report are available to the public from

International Monetary Fund - Publication Services

700 19th Street, N.W. • Washington, D.C. 20431

Telephone: (202) 623-7430 - Telefax: (202) 623-7201

Telex (RCA): 248331 IMF UR

E-mail: publications@imf.org

Internet: http://www.imf.org

Price: $\$ 15.00$ a copy

\section{International Monetary Fund \\ Washington, D.C.}




\section{INTERNATIONAL MONETARY FUND}

GHANA

\section{Selected Issues}

Prepared by a staff team consisting of Sérgio Pereira Leite (head), S. Fabrizio, J. Harnack, A. Pellechio, L. Zanforlin (all AFR), and T. Kanai (PDR)

Approved by the African Department

November 17, 1998

Contents

Basic Data . . . . . . . . . . . . . . . . . . . . . . . . . . 5

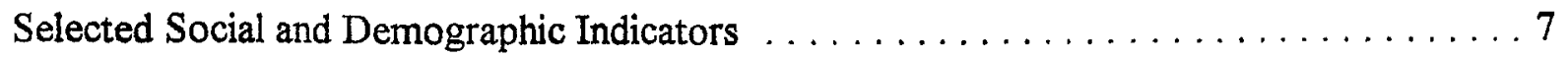

I. Public Service Reform . . . . . . . . . . . . . . . . . . . . . . 9

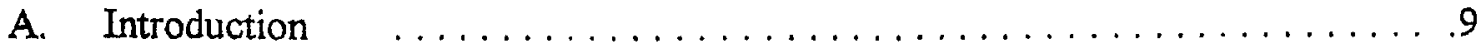

B. Overview of Public Service Reform $\ldots \ldots \ldots \ldots \ldots \ldots$.

C. The Public Sector Reinvention and Modernization Strategy (PUSERMOS) . . 14

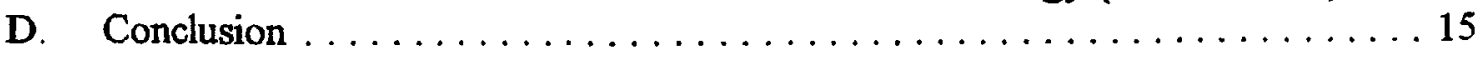

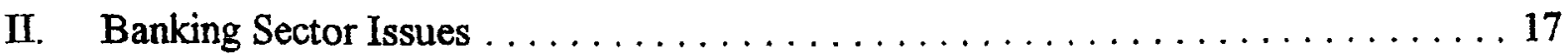

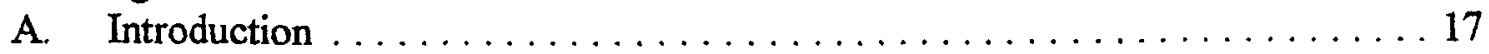

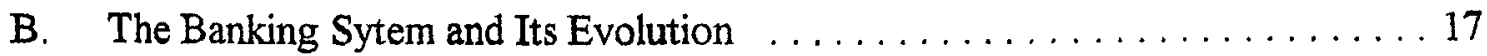

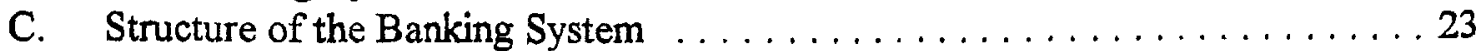

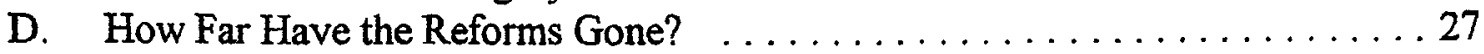

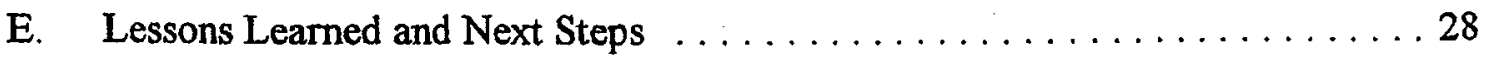

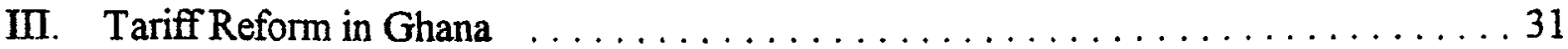

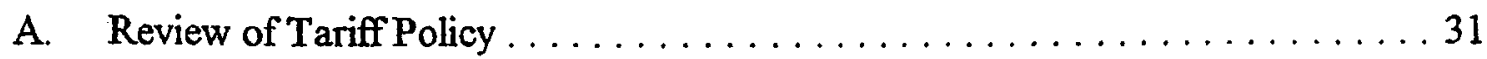

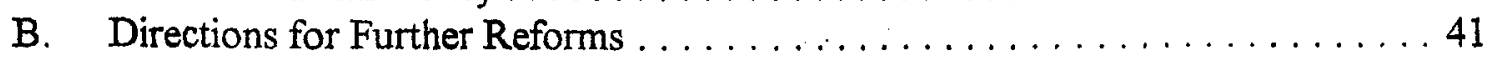

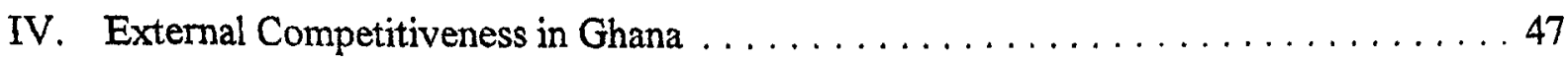

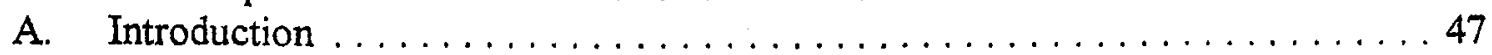

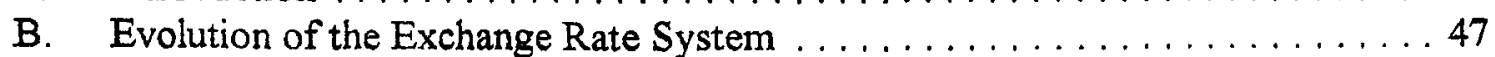

C. Traditional Competitiveness Indicators $\ldots \ldots \ldots \ldots \ldots \ldots \ldots \ldots \ldots$

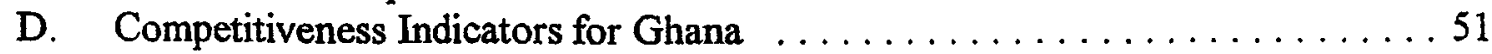

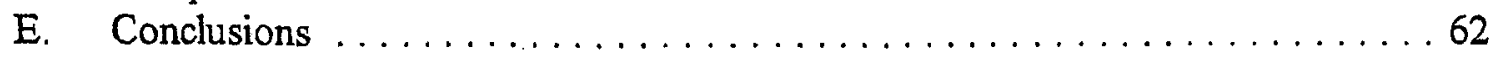


V. Trends in Cocoa World Markets and Options to Strengthen Ghana's

Competitive Position . . . . . . . . . . . . . . . . . . . . . 64

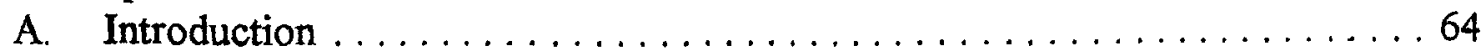

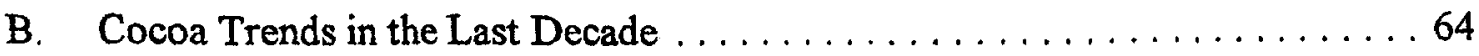

$\underline{\text { Text Figures }}$

1. Financial Deepening Indicators, $1980-96 \ldots \ldots \ldots \ldots \ldots \ldots \ldots$

2. Effective Rate of Tariff and Sales Tax on Imports, 1989-96 . . . . . . . . . . . 33

3. Share of Trade Taxes and Customs Duties in Total Tax Revenue, 1986-96 . . . . . 33

4. Selected African Countries: Statutory and Import-Weighted Averages of

Tariff Rates . . . . . . . . . . . . . . . . . . . . . . . . . . 33

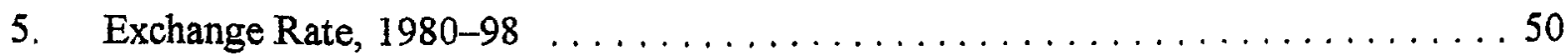

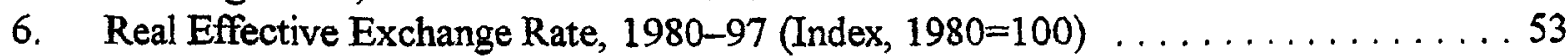

7. Real Effective Exchange Rate, $1980-98$ (Index, 1990=100) . . . . . . . . . . . 54

8. Real Effective Exchange Rate, 1980-97 (Index 1980=100, Based on

Import/Export Deflators) $\ldots \ldots \ldots \ldots \ldots \ldots \ldots \ldots \ldots$

9. Real Effective Exchange Rates, $1980-97$, (Index 1990=100) . . . . . . . . . . . 57

10. Real Effective Exchange Rate Based on Unit Labor Cost Index, 1981-97 . . . . . . 58

11. Competitiveness with Neighboring Countries, $1980-1990 \ldots \ldots \ldots \ldots$. . . . . . 6 60

12. Competitiveness with Neighboring Countries, $1990-1998 \ldots \ldots \ldots \ldots$. . . . . . . . . .61

13. World Cocoa Trends, $1987-97 \ldots \ldots \ldots \ldots \ldots \ldots \ldots$

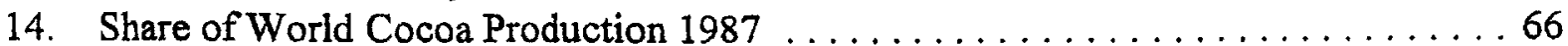

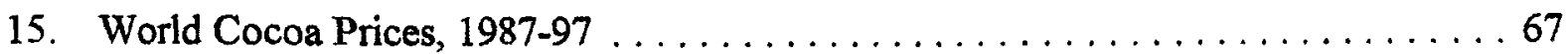

16. Côte d'Ivoire and Ghana: Production Trends, $1987-98 \ldots \ldots \ldots \ldots \ldots \ldots$

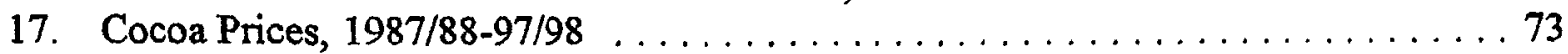

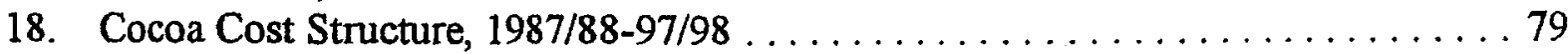

Text Boxes

1. Exchange Rate Arrangements, $1983-87 \ldots \ldots \ldots \ldots \ldots \ldots \ldots \ldots$

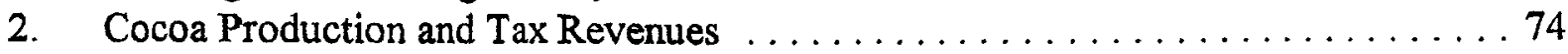

Text Tables

1. Ghana Overview of the Public Sector $\ldots \ldots \ldots \ldots \ldots \ldots \ldots \ldots \ldots$

2. Comparative Civil Service Ratios $\ldots \ldots \ldots \ldots \ldots \ldots \ldots \ldots \ldots \ldots \ldots \ldots$

3. Chronology of the Evolution of the Banking System $\ldots \ldots \ldots \ldots \ldots \ldots \ldots$

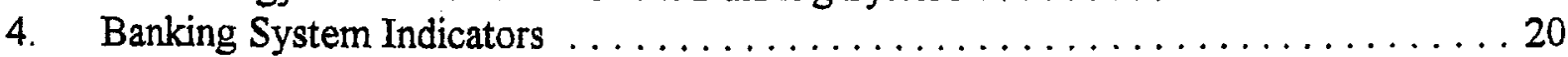

5 . Selected Banking System Indicators as of June $1998 \ldots \ldots \ldots \ldots \ldots \ldots \ldots$

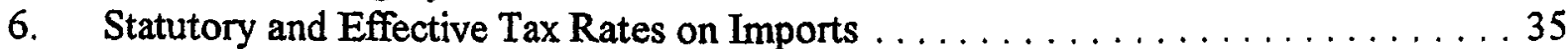

7. Share of Imports by Main Exemption Regime and Associated Revenue Loss . . . . . 36

8. Distribution of Main Immports by Exemption Regime and Associated

Revenue Loss 
9. Ranking of Main Two-Digit Fcommodity Code Imports by Import Share and Associated Revenue Loss Owing to Exemptions . . . . . . . . . . . . . 40

10. Sector Classification of Imports by Revenue Loss Owing to the Exemptions

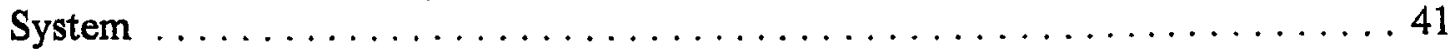

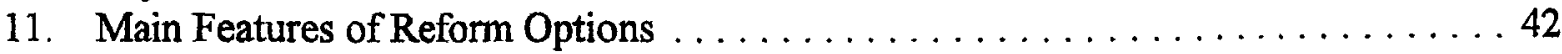

12. Simple and Import-Weighted Averages of Effective Tariff Rates Under the

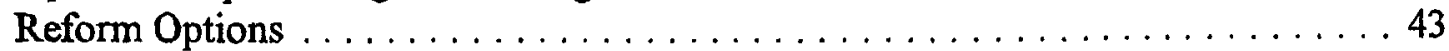

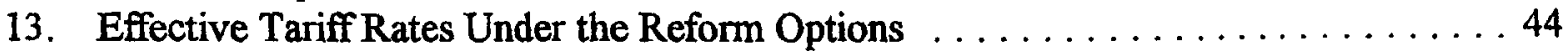

14. Effects of Reform Options on Revenue and Loss Owing to the Exemptions

System . . . . . . . . . . . . . . . . . . . . . . . . 45

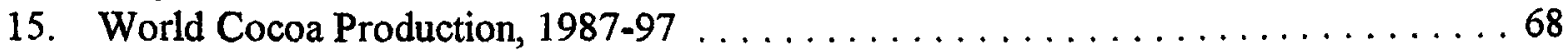

16. Distribution of Cocoa Export Proceeds, $1995 \ldots \ldots \ldots \ldots \ldots \ldots \ldots$

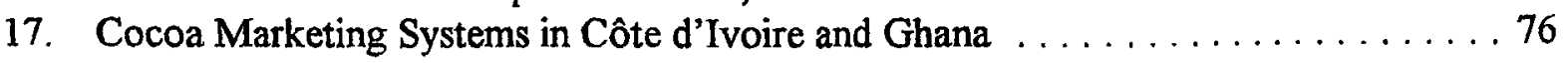

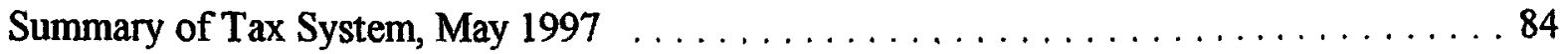

$\underline{\text { Statistical Appendix Tables }}$

18. Gross Domestic Product by Sector, 1993-97 . . . . . . . . . . . . . . . . . . . . 97

19. Gross Domestic Product by Expenditure Category, 1993-97 . . . . . . . . . . . 98

20. Composition and Growth of Gross Domestic Product by Sector,

1993-97

21. Composition and Growth of Gross Domestic Product by Expenditure

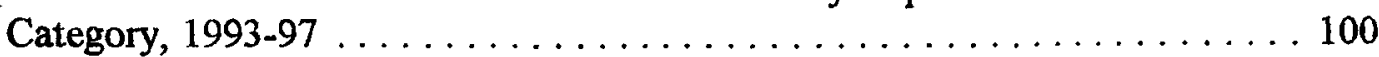

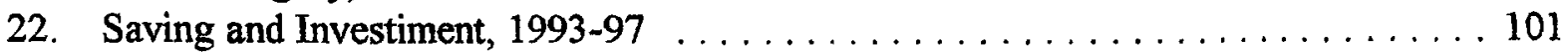

23. Cocoa Bean Production, Consumption, Prices, Payments to Farmers, and Export Receipts, 1985/86-1997/98 . . . . . . . . . . . . . . . 102

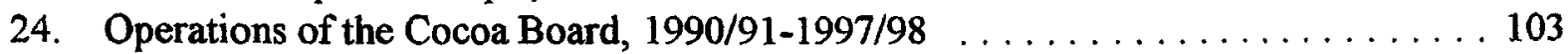

25. Production,m Acreage, and Yield of Principal Food Crops, 1991-97 . . . . . . . . 104

26. Production and Exports of Logs, Sawn Timber, Veneer, and Plywood, $1991-97$. . . . . . . . . . . . . . . . . . . . . . . . . . . . . . . . . . 105

27. Domestic Fish Catch and Imports, $1991-96 \ldots \ldots \ldots \ldots \ldots \ldots \ldots$

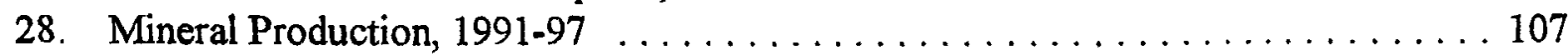

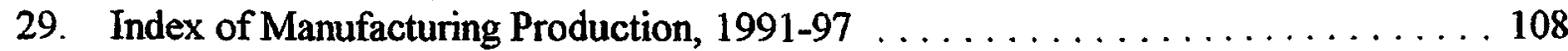

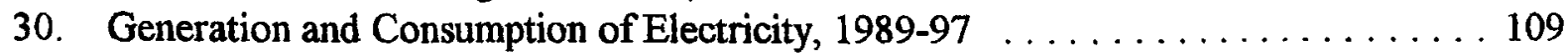

31. Average Monthly Earnings per Employee, $1980-97 \ldots \ldots \ldots \ldots$. . . . . . . . . 110

32. National Consumer Index, $1985-97 \ldots \ldots \ldots \ldots \ldots \ldots \ldots \ldots \ldots \ldots \ldots 11$

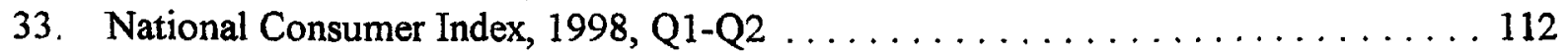

34. National Consumer Price Index, $1987-97 \ldots \ldots \ldots \ldots \ldots \ldots \ldots \ldots \ldots$

35. Average Wholesale Prices of Selected Agricultural Commodities, 1989-97 . . . . 114

36. Retail Prices of Major Petroleum Products, December 1979-Febnuary 1998 . . . . 115

37. Central Government Operations and Financing, $1990-97 \ldots \ldots \ldots \ldots \ldots 116$

38. Central Government Revenue and Grants, $1990-97 \ldots \ldots \ldots \ldots \ldots 117$ 
39. Economic Classification of Central Government Expenditure and Net

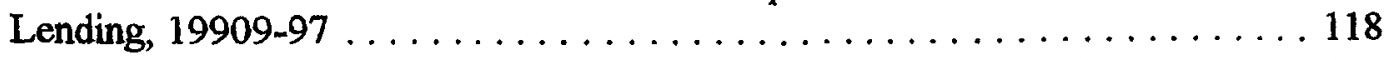

40. Functional Classification of Central Government Expenditure, 1990-95 . . . . 119

41. Distribution of Outstanding Central Government Domestic Debt, 1990-97 . . . . 120

42. Operations of the Social Security and National Investment Trust, 1990-96 . . . . . 121

43. Summary of Financial Operations of Major State-Owned Enterprises,

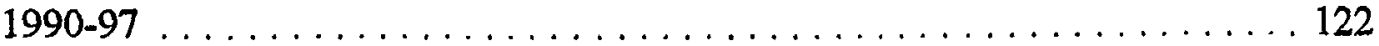

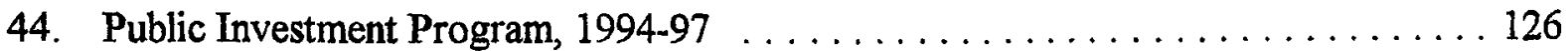

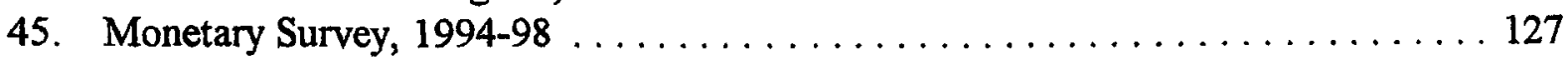

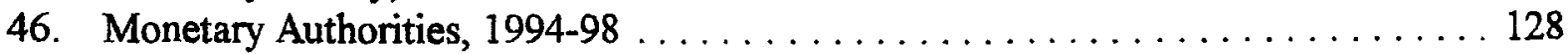

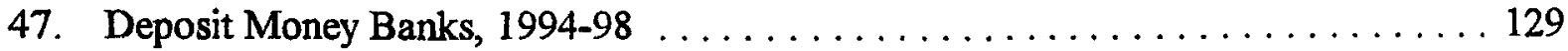

48. Distribution of Bank Loans and Advances to Public Institutions and the

Private Sector, $1991-97$. . . . . . . . . . . . . . . . . . . . . . . 130

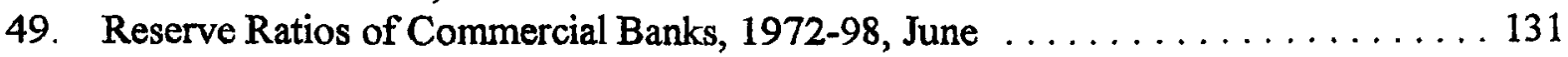

50. Interest Rate Structure of Banks, September 1995-June $1998 \ldots \ldots \ldots \ldots \ldots \ldots 132$

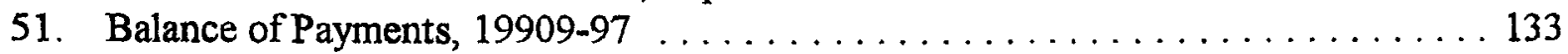

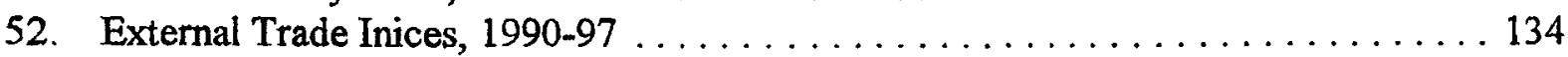

53. Value, Volume, and Unit Price of Exports, $19909-97 \ldots \ldots \ldots \ldots \ldots \ldots \ldots 135$

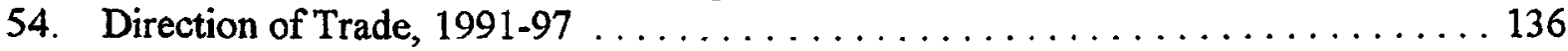

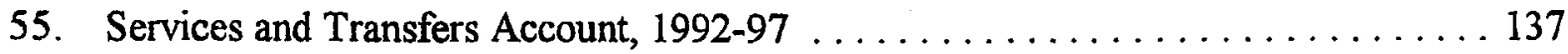

56. Clearing Accounts Under Bilateral Payments Agreements, June 1992-

December 1997 . . . . . . . . . . . . . . . . . . . . . . . . 138

57. External Public Debt and Debt Services, $1991-97 \ldots \ldots \ldots \ldots \ldots \ldots \ldots \ldots 139$

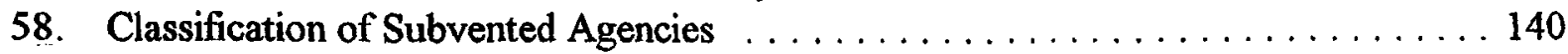


Ghana: Basic Data

I. Social and Demographic Indicators

Area:

Population:

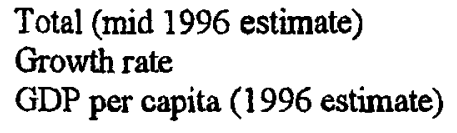

238,540 square kilometers

17.5 million

2.7 percent

SDR 260

II. Economic Indicators, 1993-97

\begin{tabular}{|c|c|c|c|c|c|}
\hline & 1993 & 1994 & 1995 & 1996 & 1997 \\
\hline & \multicolumn{5}{|c|}{ (In billions of cedis) } \\
\hline \multirow[t]{2}{*}{$\begin{array}{l}\text { Gross domestic product } \\
\text { (at current prices) }\end{array}$} & 3,873 & 5,205 & 7,752 & 11,339 & 14,113 \\
\hline & \multicolumn{5}{|c|}{ (In percent of real GDP) } \\
\hline Agriculture & 36.9 & 37.8 & 38.8 & 39.0 & 35.8 \\
\hline Industry & 24.8 & 24.9 & 24.3 & 23.6 & 25.7 \\
\hline \multirow[t]{2}{*}{ Services } & 27.5 & 27.3 & 27.8 & 26.3 & 27.9 \\
\hline & \multicolumn{5}{|c|}{ (Annual percentage change) } \\
\hline Nominal GDP & 31.1 & 41.6 & 48.9 & 46.3 & 24.5 \\
\hline Real GDP & 5.0 & 3.3 & 4.0 & 4.6 & 4.2 \\
\hline Exports (volume) & 21.7 & 2.6 & 0.3 & 12.5 & -0.6 \\
\hline Imports (volume) & 17.1 & -12.4 & -0.5 & 13.8 & 13.7 \\
\hline \multicolumn{6}{|l|}{ Prices } \\
\hline GDP deflator & 24.9 & 30.1 & 43.2 & 39.8 & 19.5 \\
\hline National consumer price index (period average) & 25.0 & 24.9 & 59.5 & 46.6 & 27.9 \\
\hline Export prices & -11.5 & 10.2 & 4.7 & -2.4 & -4.4 \\
\hline Import prices & -0.6 & 10.7 & 3.5 & 0.6 & -3.1 \\
\hline Terms of trade & -10.9 & 3.1 & 7.3 & -3.0 & -1.4 \\
\hline & \multicolumn{5}{|c|}{ (In billions of cedis) } \\
\hline Central government finance & & & & & \\
\hline Revenue and grants & 743 & 1,160 & 1,865 & 2,289 & 2,709 \\
\hline Expenditure and net lending & 1,124 & 1,622 & 2,359 & 3,370 & 4,002 \\
\hline Of which : current expenditure & 694 & 930 & 1,271 & 1,861 & 2,364 \\
\hline Surplus or deficit $(-)$ & .382 & -462 & -495 & $-1,082$ & $-1,293$ \\
\hline (In percent of GDP) & -10.4 & -9.3 & -6.7 & -9.5 & -9.2 \\
\hline Foreign financing (net) & 241 & 236 & 336 & 418 & 509 \\
\hline Domestic financing (net) & 45 & -39 & -28 & 531 & 762 \\
\hline \multirow[t]{2}{*}{ Of which : banking system } & -22 & -44 & -67 & 226 & 528 \\
\hline & \multicolumn{5}{|c|}{ (Annual percentage change) } \\
\hline \multicolumn{6}{|l|}{ Money and credit (end-of-period) $1 /$} \\
\hline Net domestic assets $2 / 3 /$ & 2.6 & 20.5 & 15.8 & 32.3 & 33.5 \\
\hline Net claims on the government $2 / 3$ / & -3.9 & -5.9 & 6.6 & 12.8 & 22.0 \\
\hline Credit to rest of the economy $3 / 4 /$ & 11.3 & 23.1 & 15.0 & 15.7 & 20.9 \\
\hline Broad money $5 /$ & 11.3 & 23.1 & 40.8 & 39.7 & 40.8 \\
\hline Velocity (ratio GDP/M2) & 5.6 & 5.5 & 5.6 & 5.6 & 4.9 \\
\hline
\end{tabular}

I:Idoclwrighalm98-2lredlghadbrdt.xls 
Ghana: Basic Data (concluded)

\begin{tabular}{|c|c|c|c|c|c|}
\hline & 1993 & 1994 & 1995 & 1996 & 1997 \\
\hline & \multicolumn{5}{|c|}{ (In millions of U.S. dollars) } \\
\hline \multicolumn{6}{|l|}{ Balance of payments } \\
\hline $\begin{array}{l}\text { Exports, f.o.b. } \\
\text { Of which: }\end{array}$ & 1,064 & 1,227 & 1,431 & 1,571 & 1,492 \\
\hline Cocoa beans and products & 286 & 320 & 390 & 552 & 470 \\
\hline Noncocoa products & 778 & 907 & 1,042 & 1,045 & 1,020 \\
\hline Imports, f.o.b. & $-1,728$ & $-1,580$ & $-1,687$ & $-1,931$ & $-2,128$ \\
\hline Of which: Oil & -154 & -171 & -191 & -253 & -234 \\
\hline Trade balance & -664 & -353 & -256 & -361 & -638 \\
\hline Services and transfers (net) & 105 & 88 & 114 & 40 & 42 \\
\hline Current account balance & -559 & -265 & -142 & -321 & .594 \\
\hline Capital account net & 630 & 479 & 432 & 279 & 540 \\
\hline \multicolumn{6}{|l|}{ Of which } \\
\hline Official capital (net) & 370 & 295 & 170 & 358 & 499 \\
\hline Errors and omissions & -30 & -50 & -6 & 28 & 79 \\
\hline Overall balance & 41 & 164 & 284 & -14 & 25 \\
\hline \multicolumn{6}{|l|}{ Current account balance } \\
\hline (in percent of GDP) & -9.4 & -4.9 & -2.2 & -4.6 & -8.6 \\
\hline \multicolumn{6}{|l|}{ Gross official international reserves } \\
\hline End-of-period & 420 & 593 & 710 & 605 & 508 \\
\hline In months of imports, c.i.f. & 2.7 & 4.1 & 3.4 & 2.6 & 2.6 \\
\hline \multicolumn{6}{|l|}{ External public debt } \\
\hline \multicolumn{6}{|l|}{ Disbursed and outstanding } \\
\hline (end-of-period; including the Fund) 61 & 5,444 & 5,703 & 5,875 & 6,174 & 6,549 \\
\hline \multicolumn{6}{|c|}{$\begin{array}{l}\text { Debt service } \\
\text { (in percent of exports of goods and non factor services) }\end{array}$} \\
\hline Including the Fund & 35.7 & 27.4 & 35.8 & 27.4 & 32.3 \\
\hline Excluding the Fund & 29.1 & 20.5 & 28.3 & 19.5 & 21.9 \\
\hline \multicolumn{6}{|l|}{ Exchange rates } \\
\hline End-of-period & 822 & 1,051 & 1,446 & 1,740 & 2,250 \\
\hline Period average & 649 & 957 & 1,200 & 1,637 & 2,050 \\
\hline
\end{tabular}

Source: Ghanaian authorities.

1/ As of December 1996, the coverage was increase from 11 to 17 banks.

2/ Figures for 1993 include takeover of the accumulated revaluation losses of the Bank of Ghana

by the government.

3/ Percentage change in relation to beginning money stock (M2).

4/ Includes cocoa financing.

5/ Broad money includes all foreign currency deposits held in commercial banks.

5/ Public and publically guaranteed medium- and long-term debt.

r:ldoclwrlghalm98-2 \redlghadbrdt.xls 
Ghana: Selected Social and Demographic Indicators

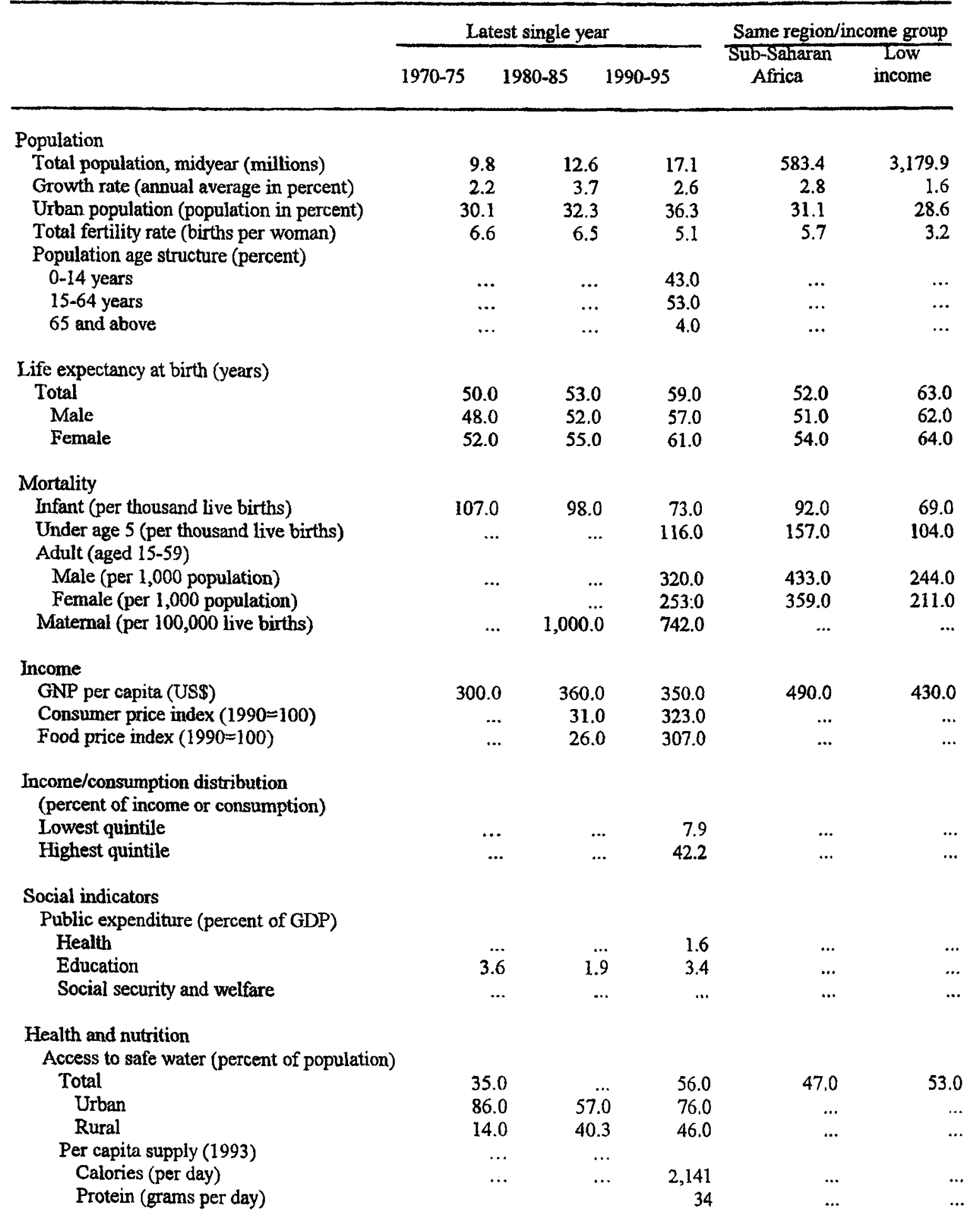


Ghana: Selected Social and Demographic Indicators

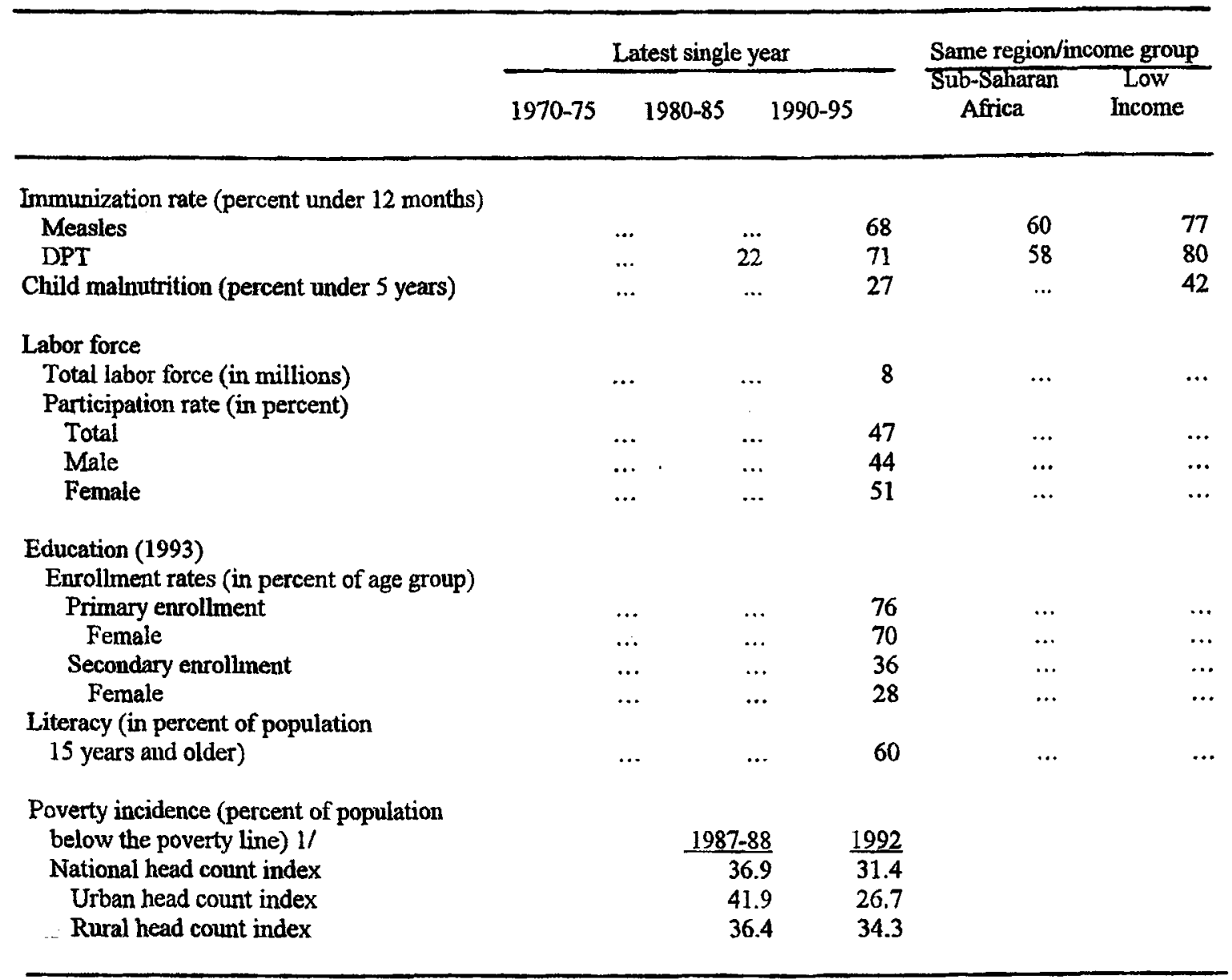

Sources: Ghana Statistical Service, Quarterly Digest of Statistics; MMF, International Financial Statistics; and the World Bank.

1/ Poverty line estimated at Cedi 132,230 per year as at mid-1992. Based on the living standards surveys conducted by the Ghana Statistical Service in collaboration with the World Bank during 1987/88,1988/98, and 1991/92.

r:Idoclwrlghal98-2ไredlghasnr. vle

CInternational Monetary Fund. Not for Redistribution 


\section{Ghana: Public Service Reform ${ }^{1}$}

\section{A. Introduction}

1. A range of public service reform initiatives have been undertaken in Ghana since the early 1980s. However, they were introduced and implemented in an ad hoc manner, and have fallen short of intended outcomes. In order to make the public sector more cost effective and supportive of the private sector, the government launched the National Institutional Reform Program (NIRP) in late 1994. The NIRP intends to achieve these objectives through better coordination of the government's reform programs, particularly those aimed at (a) making the public sector more compact and efficient; (b) enhancing the compensation structure to enhance motivation, skills, and good governance; and (c) establishing monitorable indicators of progress and a timetable to complete the reforms.

2. The National Oversight Committee (NOC), a 20-member executive board with private sector participation, was established to oversee the work of the NIRP secretariat. Its authority was substantially enhanced in mid-1997 with the appointment of the Vice President of Ghana as Chairman.

\section{B. Overview of Public Service Reform}

3. The public service in Ghana is composed of centrally managed agencies, ministries, subvented agencies, district assemblies, and state enterprises (Table 1). The civil service, which covers the centrally managed agencies, ministries, and local government, accounts for onily about twenty percent of total public sector employment as a result of the spin-off in the 1980 s of the internal revenue, customs, education, and health services as subvented agencies.

4. During the period 1987-1994, public service reforms were introduced on a piecemeal basis. A lack of control over hirings and wages levels, notably at subvented agencies and state enterprises, resulted in an increasing government wage bill and wide disparity in wages among the various services. Nonetheless, job inspections and management reviews resulted in the reduction of the number of civil servants in central government from about 140,000 in 1987 to 90,000 in 1994; approximately 7,000 layoffs were due to the removal of "ghost" workers. Laid-off personnel received a redeployment package that was partly financed by the World Bank. In 1997, Ghana's wage bill was 5.4 percent of GDP, close to the unweighted average for 18 selected African countries, with the number of civil servants at about 84,000 in central government and almost 123,000 including local government. The ratio of the number of employees in the civil service and subvented agencies to total population was the second highest in the sample (Table 2).

\footnotetext{
${ }^{1}$ Prepared by Joachim Harnack and Anthony Pellechio.
} 
Table 1. Ghana: Overview of the Public Service

(As of end-1997)

\begin{tabular}{|c|c|c|c|c|c|}
\hline & $\begin{array}{c}\text { Centrally Managed } \\
\text { Agencies }\end{array}$ & Ministries & Local Government & $\begin{array}{l}\text { Subvented } \\
\text { Agencies }\end{array}$ & $\begin{array}{c}\text { State-Owned } \\
\text { Enterprises }\end{array}$ \\
\hline Number of units & 6 & $\begin{array}{l}21, \text { with } 50 \\
\text { departments }\end{array}$ & $\begin{array}{l}10 \text { Regional } \\
\text { Coordinating Councils; } \\
110 \text { District Assemblies }\end{array}$ & 176 & 300 \\
\hline Main functions & $\begin{array}{l}\text { Provide human, } \\
\text { financial, and } \\
\text { policy/legal services } \\
\text { to entire public } \\
\text { service }\end{array}$ & $\begin{array}{l}\text { Policy formulation } \\
\text { and monitoring by } \\
\text { ministries, and } \\
\text { implementation by } \\
\text { departments }\end{array}$ & $\begin{array}{l}\text { Policy formulation and } \\
\text { implementation of } \\
\text { development plans }\end{array}$ & $\begin{array}{l}\text { Implementation } \\
\text { of policies }\end{array}$ & $\begin{array}{l}\text { Promote } \\
\text { industrial } \\
\text { development }\end{array}$ \\
\hline Staff & 7,363 & 77,009 & 38,494 & $416,0001 /$ & 43,166 \\
\hline Cumulative total & 7,363 & 84,372 & 122,866 & 538,866 & 582,043 \\
\hline $\begin{array}{l}\text { Wages in percent of } \\
\text { central government } \\
\text { personnel outlays }\end{array}$ & 4.1 & 46.7 & 1.4 & 47.8 & $\ldots 2 /$ \\
\hline
\end{tabular}

Source: National Institutional Renewal Program, Public Sector Reinvention and Modernisation Strategy, December 1997.

1/ Of which teachers: 180,000 .

2/ Not part of the central government budget.

R:WOCIWRIGHALM98-2LREDIPUBSERV.TB1 November 16, 1998 (6:46pm) 
Table 2. Comparative Civil Service Ratios

\begin{tabular}{|c|c|c|c|c|c|c|}
\hline & \multicolumn{2}{|c|}{ Civil service } & \multicolumn{4}{|c|}{ Wages } \\
\hline & \multicolumn{2}{|c|}{$\begin{array}{cc}\text { As ratio } \\
\text { to population }\end{array}$} & \multicolumn{3}{|c|}{ In percent of GDP } & \multirow{2}{*}{$\begin{array}{c}\text { Ranking 1 } \\
1997 \\
\end{array}$} \\
\hline & 199 & & 1995 & 1996 & 1997 & \\
\hline Benin & 0.6 & 14 & 5.9 & 5.6 & 5.0 & 10 \\
\hline Botswana & 4.5 & 1 & 8.8 & 8.4 & 9.6 & 1 \\
\hline Burkina Faso & 0.4 & 17 & 5.3 & 5.0 & 4.8 & 12 \\
\hline Cameroon & 1.2 & 4 & 4.7 & 4.1 & 4.3 & 13 \\
\hline Côte d'Ivoire & 0.8 & 9 & 6.9 & 7.1 & 6.8 & 3 \\
\hline Gambia, The & 0.9 & 7 & 6.0 & 5.9 & 6.4 & 6 \\
\hline Ghana & 3.2 & 2 & 5.8 & 5.4 & 5.3 & 9 \\
\hline Guinea & 0.8 & 9 & 4.3 & 4.4 & 4.2 & 15 \\
\hline Kenya & 0.9 & 7 & 9.8 & 8.8 & 9.0 & 2 \\
\hline Malawi & 1.2 & 4 & 7.0 & 5.0 & 5.9 & 7 \\
\hline Mali & 0.4 & 17 & 3.9 & 3.7 & 3.8 & 16 \\
\hline Mozambique & 0.5 & 15 & 2.9 & 2.7 & 3.0 & 18 \\
\hline Niger & 0.5 & 15 & 5.3 & 3.3 & 4.3 & 13 \\
\hline Senegal & 0.8 & 9 & 6.5 & 6.9 & 5.7 & 8 \\
\hline Tanzania & 1.0 & 6 & 4.2 & 4.6 & 4.9 & 11 \\
\hline Togo & 0.8 & 9 & 8.1 & 7.1 & 6.6 & 4 \\
\hline Uganda & 0.7 & 13 & 2.5 & 2.7 & 3.3 & 17 \\
\hline Zambia & 1.3 & 3 & 6.3 & 5.4 & 6.5 & 5 \\
\hline
\end{tabular}

Sources: IMF, African Department, "Civil Service Data by Country"; and IMF, African Department, "World Economic Trends in Africa."

$1 / 1=$ highest. 
5. The initiatives under the scope of the NIRP can be summarized as follows:

6. Civil Service Performance Improvement Program (CSPIP). This program was launched by the Office of the Head of Civil Service in March 1995, covering 190 organizations with about 81,000 staff. $^{2}$ It addresses issues of motivation and performance, focussing on divisional and individual performance improvement plans, consolidation of the computerization process, and manpower ceilings. Feedback from managers resulted in the identification of 16 common problem areas in the civil service, and discussion groups have been set up to help solve these issues. The program is scheduled to run until 2006; as of mid1998, 125 agencies had passed the problem identification stage.

7. Public seryice wage reform. In 1996, the Public Services Commission, with assistance from Price Waterhouse, began a review of the salary structure of the public service with the aim of resolving the long-standing issue of wage disparities. The review has three main objectives: eliminating ad hoc approaches to income administration in the short-term; establishing a remuneration policy implementation plan in the medium term, mainly based on a comprehensive exercise of job classification; and developing a sustainable structure for the long term in line with Ghana's Vision 2020 report on the Coordinated Program of Economic and Social Development Policies.

8. Because the government felt that wage structure and job classification issues transcended the public sector, it opted to work in the context of a Tripartite Commission, which includes trade unions and employers. Following several meetings, the government issued a confidential report-the "Price Waterhouse Report"-in mid-1998 outlining its proposed strategies from 1999 onward. The stated guiding principle of the report was to put into place a uniform salary structure based on tasks instead of positions. This implies a salary alignment in the short term and a salary adjustment in the medium term. The government is aware that the salary structure must be consistent with its macroeconomic targets, notably as regards prices. The social partners will give their reactions by end-1998. In the meantime, the government has granted an across-the-board 20 percent salary increase as a relief allowance for price increases, instead of the standard annual adjustment of the salary structure.

9. Decentralization reform. The local government law of 1988 created the District Assemblies as a first step toward decentralization. The Constitution of 1992 introduced the District Assembly Common Fund (DACF) for development programs, which receives at least 5 percent of central government domestic tax revenue. The Village Infrastructure Project of the World Bank is to be channeled through the DACF. It was seen early on, however, that district administrations were weak, and efforts were begun to strengthen their expenditure

\footnotetext{
${ }^{2}$ These organizations encompass 22 ministries, including the Office of the President, 48 departments and agencies, 10 regional coordinating councils, and 110 district assemblies. Subvented agencies and state-owned enterprises (SOEs) were not covered under CSPIP.
} 
allocation and project implementation capabilities. However, progress was slow, and in 1995 the long-standing practice of funding half of local government staff salaries through the central government budget was abandoned in favor of full central funding. This was done in order to obtain better control over hiring policies of the district assemblies. A Local Government Act is being presented to parliament, which will create the administrative and accounting framework for the 110 district authorities.

10. As the government withdraws from the direct provision of services-both through privatization and removal of entry barriers-it is redefining its role as principally regulation of these activities. In this context, the government has established the independent Public Utilities Regulatory Commission (PURC) to review pricing and standards in the electricity and water sectors; the Energy Commission to monitor pricing in the petroleum sector and issue licenses to independent power producers; and the National Communications Agency to oversee the telecommunications sector.

11. State-owned enterprise (SOE) reform. The state enterprise sector is supervised by the State Enterprise Commission (SEC). As such, it is responsible for implementing the SOE reform program, whose objectives are developing the capacity of the SEC to monitor and evaluate the performance of the SOEs, including by improving the data base; strengthening the operation of the SEC's performance contract system; building capacity within the Ministry of Finance and the SEC to coordinate the implementation of the program and to manage the government's portfolio of equity investments, loans, and guarantees; and preparing selected SOEs for divestiture as well as building capacity within the Divestiture Implementation Committee (DIC) to accelerate the divestiture program.

12. The institutional framework for the sector is centered on the performance contract system, started in 1989, which introduced the concept of corporate planning to managers. It was initially set up for 12 enterprises; by 1995 this had increased to 47. In 1997 the SEC decided that all SOEs had to adopt performance contracts. This has helped improve the financial performance of the sector, further supported by the Statutory Corporation Act of 1993 aimed at standardizing regulations for SOEs and developing diagnostic action plans. As a result, government subsidies have virtually ceased, and privatization has accelerated.

13. The corporate planning process covers 3-5 years on a rolling basis with annual targets. The achievements under the plan are reviewed by the SEC and the Ministry of Finance at the end of the year, and grades and incentive bonuses (if called for) are determined. In 1997, 15 percent of enterprises had received a top grade, 40 percent a middle grade, and the remainder an unsatisfactory grade-mainly because of shortfalls in profitability and governance. The process will be further tightened in 1999-including through a more rigorous application of sanctions such as dismissal of managers.

14. While important progress has been achieved, the reforms are now entering a new phase both in terms of significance of the enterprises to be tackled and the need to increase the transparency of the reform process. In May 1998, the government added economically 
significant state owned corporations to their divestiture list; including Ghana Airways, the Ghana Water and Sewerage Corporation, and all remaining state-owned banks. The list, which is posted on the DIC website, includes a provisional timetable. The government is committed to keeping the public informed, and will provide the number of bidders selected, the value of the transaction, as well as the DIC's audited accounts.

15. Public Expenditure Reform. In 1997, the government embarked on a comprehensive improvement of its procedures for budgetary planning, implementation, and monitoring under the Public Financial Management Reform Program (PUFMARP). The program is supported by the World Bank and other donors. As a first step, the government designed a new budget and public expenditure management system (BPEMS), which is expected to be fully operational in 2000 . It will improve budget preparation and implementation, streamline cash management, and strengthen accounting procedures.

16. Accompanying the BPEMS is the medium-term expenditure framework (MTEF), designed to merge sectoral policy decisions with budget constraints. The sectoral policies are calibrated on a rolling 3-year macroeconomic and budgetary framework. Activities, such as primary education for one child or rehabilitating a mile of feeder road, are costed to determine what policy targets can be achieved within a ministry's overall budget ceiling. The government's aim is to have the MTEF fully operational for 2000. In preparation, the government has issued guidelines for the 1999 budget that include a macroeconomic framework consistent with the Policy Framework Paper (PFP) and budget guidelines for each entity over the next three years consistent with available resources.

\section{The Public Sector Reinvention and Modernization Strategy (PUSERMOS)}

17. When the NIRP was created, information was collected on the various public sector agencies based on a common review instrument, the Self-Appraisal Instrument (SAI). By the end of 1996, 250 institutions had been analyzed, and the information was used for a national workshop organized in May 1997. The workshop focused on coordination of reforms and development of human resources and was chaired by the Vice President, who had recently been appointed Chairman of the NOC. It developed a strategy for the next ten years covering the broad spectrum of public sector reforms, entitled the Public Sector Reinvention and Modernization Strategy (PUSERMOS). This strategy was approved by the Cabinet on December 18, 1997, and the NIRP was instructed to begin a pilot phase that would be completed no later than end-1999.

18. PUSERMOS seeks to clearly delineate functions of all components of the public sector, achieve efficient management and execution of these functions, attain effective delivery of services, and instill good governance. In addition to redefining and clarifying the national policy process through a Policy Management Group at the Office of the President, the PUSERMOS stresses reforms in two public service sectors: subvented and central management agencies. These reforms are to be implemented over the next ten years and would allow a significant decentralization of the government's activities. At the end of the 
period, the civil service is to comprise no more than 2,500 staff, down from 84,000 presently. The restructured subvented agencies and local government institutions will absorb most of the staff moving from the civil service. Thus, the main focus of the strategy is not downsizing but reallocating functions within the public service. Nonetheless, severance costs are expected and the government will consider these in drafting each year's budget. The World Bank is supporting this reform effort through financial and technical assistance, guided by the conditions established under the Economic Reform Support Operation (ERSO). It encompasses assistance for the pilot project and preparation of a fully costed three-year reform program.

19. Subvented agencies employ over 70 percent of the civilian public service and include the education and health services, Highways Authority, universities, and a myriad of smaller agencies. They have been classified into four categories, viz., those that will be: (1) wholly subvented; (2) partially subvented; (3) wholly commercialized; and (4) closed down (Table 58). The NIRP's pilot phase covers at least 7 agencies in the first two categories, 5 in the third category, and 5 in the fourth category. Environmental studies, the legal framework, and procedures for closing down or commercializing subvented agencies are to be completed by end-1998. At that time, the Cabinet is expected to approve the specific subvented agencies for this phase.

20. The central management agencies (CMAs) will be reformed in a two-phase approach. ${ }^{3}$ The first phase will target the Ministry of Finance and Public Service Commission, that is, the very bodies carrying out the reforms. Putting a more coherent and transparent regulatory environment in place for them is therefore a prerequisite for launching the reforms. The initial activities will include a functional analysis of personnel management, budget and financial planning and implementation, and policy development; developing recommendations for streamlining functions among the CMAs; consensus building through focus group discussions; and costing and planning the reforms. This is complemented by work already underway to reform budget planning and management (PUFMARP), and improve Cabinet decision making.

\section{Conclusion}

21. Successful implementation of the PUSERMOS will be crucial to attaining the financial targets under the ESAF and World Bank programs. Ghana's government machinery will greatly benefit from modernization, both by making it more efficient and giving it the desired transparency. Specifically, without the reforms aimed at containing public expenditure, Ghana will be hard pressed to achieve the domestic primary surpluses that will allow it to "crowd in" the private sector and thus, through increased private sector activity, accelerate growth.

Similarly, streamlining the subvented agencies will be crucial to instilling a sense of managerial

\footnotetext{
${ }^{3}$ The 14 CMAs include the Office of the President; the Cabinet; the National Development and Planning Commission (NDPC); the Office of the Head of the Civil Service; the Ministry of Finance; and the Public Service Commission.
} 
responsibility in government operations. Thus, the size of the public sector and the time frame for the reforms need to be kept under constant review for the government to be able to actively support Ghana's development. 


\section{Ghana: Banking SECTOR Issues 4}

\section{A. Introduction}

22. From 1989 to 1991 , Ghana implemented a financial sector reform program aimed at rehabilitating its financial system, which suffered from inefficiency, lack of competition, and a large portfolio of nonperforming loans. Measures were taken to liberalize interest rates, revamp financial sector legislation, and strengthen bank supervision. These banking sector reforms were costly. Nonperforming loans were swapped for interest-bearing bonds and banks were recapitalized, at a cost estimated at about 6 percent of GDP. ${ }^{5}$ This chapter analyzes the strategy used to restructure the Ghanaian banking system and draws some lessons. The chapter is organized as follows. Section B reviews the development of the financial system in Ghana; the early reforms of 1989-91; and the second wave of reforms, characterized by the divestiture process that began in 1992 and is still ongoing. Section $C$ describes the status of the banking sector at present, and compares it with the situation in other countries. Sections D and $E$ summarize the main findings and point out issues that remain to be addressed.

\section{B. The Banking System and Its Evolution}

\section{Historical Background}

23. The first commercial banks set up in Ghana at the beginning of the twentieth century still operate today as Standard Chartered Ghana (SCB) and Barclays Bank Ghana (BBG) (see Table 3). Under colonial rule, their main business was trade finance, and they mainly served the expatriate community. In 1953, the first indigenous commercial bank, now Ghana Commercial Bank (GCB), opened to provide credit services to the local population. Following independence in 1957, the Bank of Ghana (BoG) was established, to serve as a central bank for the economy and to take over some of the functions that had been previously undertaken by the West African Currency Board. Throughout the period 1957 to 1983, the government followed a policy of intervention in economic activity and held a controlling interest in all commercial banks. Three state-owned development banks were established during this period: the National Investment Bank (NIB), the Agricultural Development Bank (ADB) and the Bank for Housing and Construction (BHC). In 1983, after the launching of the Economic Recovery Program, financial sector reforms were initiated, and private commercial banks were allowed to operate.

\footnotetext{
${ }^{4}$ Prepared by Luisa Zanforlin. This chapter benefited from data collected by an MAE mission consisting of Mr. Ugolini (head), Mr. McConnell, and Ms. Schumacher (consultants).
}

${ }^{5}$ See C. Dziobek and C. Pazarbašioğlu (1997). 
Table 3. Ghana: Chronology of the Evolution of the Banking System

1888

1896

1912

1917

1953

1957

1964

1965

1972

1972

1977

1981

1988

1987

1989

1990
Government Savings Bank is set up

(British Bank of West Africa) Standard Chartered Bank of Ghana begins operations

West African Currency Board is set up together with Gambia, Nigeria and Sierra Leone

(Colonial Bank) Barclays Bank of Ghana begins operations

(Bank of the Gold Coast) Ghana Commercial Bank begins operations

Bank of Ghana is set up

National Investment Bank is created

Agricultural Development Bank is created

Bank for Housing and Construction is created

Repudiation of loans contracted by previous governments

Social Security Bank is set up, wholly owned by SSNIT

Freeze of deposits of 50,000 cedis or more

Private banks are authorized to operate

September

Liberalization of commercial bank interest rates

Bank restructuring plan adopted by government

August New banking law strengthening the regulatory environment and the supervisory authority of the Bank of Ghana adopted

January Appointment of new management and boards of directors for all financially distressed banks

April Implementation of restructuring plans for three financially distressed banks begins

May Nonperforming loans of state enterprises in three financially distressed banks are replaced by BoG FINSAP bonds

November
Abolition of requirement to lend to agriculture and decontrol of all bank charges and fees 
Table 3. Ghana: Chronology of the Evolution of the Banking System

November Implementation of restructuring plans for three additional financially distressed banks begins

December Nonperforming loans of the private sector in financially distressed banks are replaced, primarily with BoG bonds

December First compliance test based on new capital adequacy requirements

1991 March Restructuring plan for a seventh financially distressed bank is finalized

March Nonperforming loans of the private sector in four sound banks are replaced by BoG FINSAP bonds

1992 February Government announces strategy to divest its bank shares

October New BoG law is enacted providing for stronger supervisory and regulatory powers

1993 May New Financial Institutions (Non-Banking) Law and Home Mortgage Law are enacted

1995 March Public offer of 30 percent of government shares in Social Security Bank (SSB) after merger with National Savings and Credit Bank: 21 percent only is subscribed

October Placement of 60 percent of the capital of the SSB through the Ghana Stock Exchange (GSE)

1996 February Placement of 30 percent of government shares in GCB through the GSE; after oversubscription the public offer is raised to 42 percent

A major check fraud, the A-Life affair, causes large losses to three state-owned banks

1998 June Government divests $3 / 4$ of the remaining 40 percent shares it held in Barclays Bank

Sources: Kapur, I, and al., 1997; and information provided by the Ghanaian authorities. 
Table 4. Ghana: Banking System Indicators

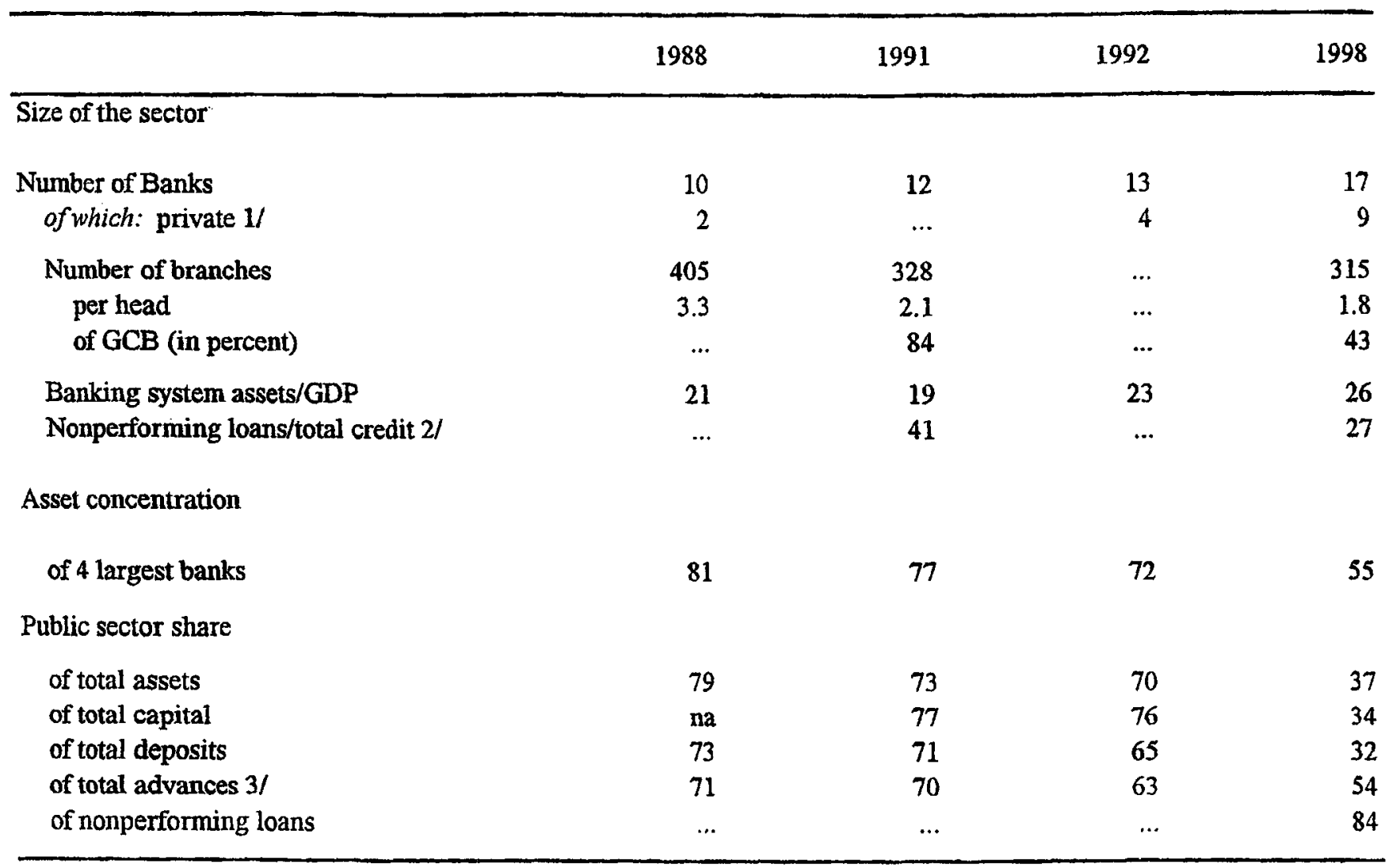

Source: Ghanaian authorities, World Bank and IMF staff estimates.

1/ With more than 60 percent private capital (Barclays Bank, Local Branch of BCCI and Continental Acceptance Ltd. are here considered mixed ownership).

2/ June 1998 estimate.

3/ Total credit to the private sector. 
Table 5. Ghana: Selected Banking System Indicators as of June 1998

\begin{tabular}{lcccc}
\hline Ownership Type & $\begin{array}{c}\text { Nonperforming } \\
\text { Loans 1/ }\end{array}$ & $\begin{array}{c}\text { Total } \\
\text { Provisions 2/ }\end{array}$ & $\begin{array}{c}\text { Net Open } \\
\text { Position 3/4/ }\end{array}$ & $\begin{array}{c}\text { Return on } \\
\text { Assets 5/ }\end{array}$ \\
\hline State & 50.8 & 69.4 & 78.7 & -26.2 \\
Private & 7.0 & 68.2 & 31.9 & 6.7 \\
Mixed & 47.7 & 40.0 & 46.9 & 3.0 \\
& & & 48.3 & -4.2 \\
System & 27.0 & 63.0 & & \\
\hline
\end{tabular}

$1 /$ In percent of total loans.

$2 /$ In percent of total non performing loans.

$3 /$ In percent of total shareholders funds.

4/ As of August 1998.

5/ Estimated.

r:ldoclwrighałm98-2〉tedigha8bnk3.xls

CInternational Monetary Fund. Not for Redistribution 


\section{The First Wave of Banking Reforms: 1989-91}

24. In the early eighties, after decades of state management, Ghana's banking system was in distress. Banks suffered from undue political influence, weak management, inadequate capital, outdated information and accounting systems, and poor internal controls. Moreover, they had large portfolios of nonperforming loans, insufficient provisions, and were often overexposed to a few clients, particularly state-owned enterprises. At the end of 1989, the banking system was close to a crisis, as nonperforming loans reached 41 percent of total credit. Faced with this situation, the government adopted a reform program with the objective of restructuring the banking system, while enhancing its competitiveness and efficiency. A new banking law was enacted in 1989, which laid out the basic regulatory framework for the banking system: minimum capital requirements, capital adequacy ratios, prudential lending ratios, exposure limits, accounting and auditing regulations. Supervisory activities of the BoG were also strengthened and the banks were required to submit accounts for off-site monitoring. Annual on-site inspections, as well as off-site surveillance, were to be conducted to verify banks' compliance with regulations.

25. During 1990 and 1991, most nonperforming loans in the balance sheets of banks were swapped with government-guaranteed interest-bearing bonds issued by the BoG, or were offset against liabilities to the government or the $\mathrm{BoG}^{6} \mathrm{~A}$ total of $\mathrm{C} 62$ billion nonperforming

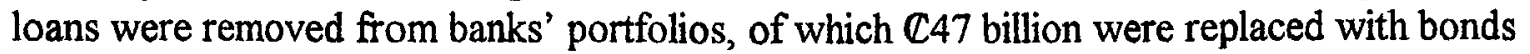
with 7,9, and 15 percent interest with a 2 to 5 year maturity, which have been since rolled over. A recovery trust for nonperforming assets was formed in 1990 (NPART). The performance of the NPART as evaluated in 1995 seemed impressive: $\mathbb{C} 13$ billion were recovered out of a total $\mathbb{C} 18$ billion outstanding in non-performing loans. However, following years of high inflation, the amounts eventually paid represented much smaller values in real terms.

\section{Divestiture and the Second Wave of Reforms: 1992-Present}

26. In February 1992, the government announced a strategy to divest its shares of commercial banks. The divestiture was intended to increase competition and efficiency in the system. The program made early progress, but quickly stalled. The Social Security Bank (SSB) and the National Savings and Credit Bank, were restructured and merged: 21 percent of shares were divested through a public offer in March 1995, while 40 percent were sold to a strategic investor. In October 1995, 60 percent of its shares were listed on the Ghana Stock Exchange. In February 1996, 30 percent of the shares of GCB, the largest bank targeted for divestiture, were floated. After the initial offer was oversubscribed, the government decided to

\footnotetext{
${ }^{6}$ As part of the bank restructuring initiative, the Bank of Ghana acquired shares in commercial banks, an operation conceived as a temporary step, but which has remained to this day. This has given rise to a potential conflict of interest. However, the BoG expects to sell all its shares in commercial banks shortly, as part of the financial sector divestiture program.
} 
increase the public offer to 42 percent of shares while looking for a strategic investor for the remaining 40 percent. Substantial delays were experienced in the negotiations with the strategic investor, partly because in 1997 the U.K. supervisory authorities objected to the proposed ownership transfer of the London Branch of GCB. Instead, the London branch was converted into an independent bank, Ghana International Bank. ${ }^{7}$ The discussions with a strategic partner GCB were still ongoing in the last quarter of 1998.

27. Four other banks had been set for divestiture: NIB, ADB, BHC and COOP.

Discussions had began in 1995 with a strategic investor for NIB but failed to come to a conclusion. After two further calls for bids, the latest of which took place in August 1998, discussions are still ongoing. The program also envisaged the merger, prior to divestiture, of ADB, the largest development bank, with COOP. This process stalled in early 1997 after the A-Life check fraud caused significant losses to COOP. The authorities are now discussing whether a merger would still be appropriate in terms of the market value of both banks and their financial position. No progress was made with the plans to divest $\mathrm{BHC}$, as its financial situation was also severely affected by the A-Life check fraud to the extent that some restructuring appears to be necessary before the government could proceed with the divestiture. In June 1998, the government divested $3 / 4$ of the remaining 40 percent of its shares in Barclays Bank.

\section{Structure of the Banking System}

28. The banking system in Ghana comprises 17 banks: 9 commercial banks, 4 development banks, and 4 merchant banks (Table 4). All together these banks account for about 90 percent of total deposits in the system. The financial sector also includes 130 rural banks, and several non-bank institutions, among which 4 brokerage companies, 2 discount houses, 7 savings and loans companies, the social security national insurance trust (SSNIT) ${ }^{8}$ and other minor financial institutions.

29. The banking penetration ratio for Ghana is relatively high. On average, Ghana has a bank branch every 54 thousand inhabitants, with the lowest branch per capita ratio in the Greater Accra region (one branch per 15 thousand) and the highest in the Northern parts of the country (one branch every 85 thousand inhabitants). About half of the banks have branches in the interior of the country, but GCB alone owns about 50 percent of all local branches, in each region of the country.

\footnotetext{
${ }^{7}$ The ownership shares in GIB are as follows: Bank of Ghana, 51 percent; the social security national insurance trust (SSNIT), 15 percent; Ghana Commercial Bank, 20 percent; ADB, 9 percent; and State Insurance Corporation (SIC), 5 percent.

${ }^{8}$ This is a partially funded, defined benefit scheme and is the largest financial institution in the country.
} 
30. Although the number of financial sector institutions is high and diverse, and has grown considerably since the early nineties, financial intermediation in the economy remains relatively modest. In 1997, the M2/GDP was 19 percent ${ }^{9}$, not too different from other countries in subSaharan Africa but roughly $1 / 3$ of industrialized countries levels. This ratio has increased by just one percentage point between 1980 and 1997 showing little progress towards financial deepening. Holdings of currency are high, about 7 percent of GDP, only slightly above the average for the 1980-86 period. Credit to the private sector as a share of GDP has showed sluggish growth, increasing by only 3 percentage points since the beginning of the financial sector reform program in 1989; it reached 8 percent of GDP in end-1997, well below the average for sub-Săharan African countries (Figure 1). The M1/M2 ratio has shown a moderate decline in the last decade, which is noteworthy in the presence of persistent high inflation. In summary, Ghana seems to be moving toward increasing the depth of its financial system, albeit at a slow pace. ${ }^{10}$

31. Financial activity continues to be concentrated in a small number of core banks, though the changes with respect to the late eighties are more visible in this area. The potential for competition is well above the average of sub-Saharan Africa as none of the five top banks is excessively dominant. The Herfindahl concentration index for the top five banks in Ghana is 0.23 , well below the average for sub-Saharan Africa (0.38 in 1996). Nevertheless, in August 1998, the two top banks alone held about 44 percent of deposits and 41 percent of assets of the banking system. The top five banks accounted for 76 percent of assets and 78 percent of deposits of the banking system. Public sector banks, which in 1992 accounted for 70 percent of the assets of the banking system, have lost their dominance but still account for 37 percent of assets and 32 percent of deposits (Table 3). ${ }^{11}$

32. As in many other developing countries, the average share of nonperforming loans in the banking system is very high ( 27 percent of total credit to the private sector). However, if three small banks are excluded from the calculation, the average drops considerably (14 percent). Most of the nonperforming loans are held by state-owned banks (about 84 percent of the total), representing about 50 percent of total credit to the public of these banks. The average share of nonperforming loans in mixed ownership banks is similar to that of the state owned banks, while in private sector banks it drops to about 7 percent (Table 5).

${ }^{9}$ Excluding foreign currency deposits. The ratio including foreign currency deposits was 23.5 percent in 1997, but a comparable figure is not available for 1980 .

${ }^{10}$ The apparently slow progress toward financial deepening has to be assessed in light of the economic dislocations of the 1970s and 1980s in Ghana. Also, the financial deepening indicators discussed in this charpter do not necessarily capture all facets of financial sector development.

${ }^{11}$ Fifty-two percent of deposits and assets, if one includes banks in which the government has minority shareholding. 
Figure 1. Ghana: Financial Deepening Indicators, 1980-96 1/
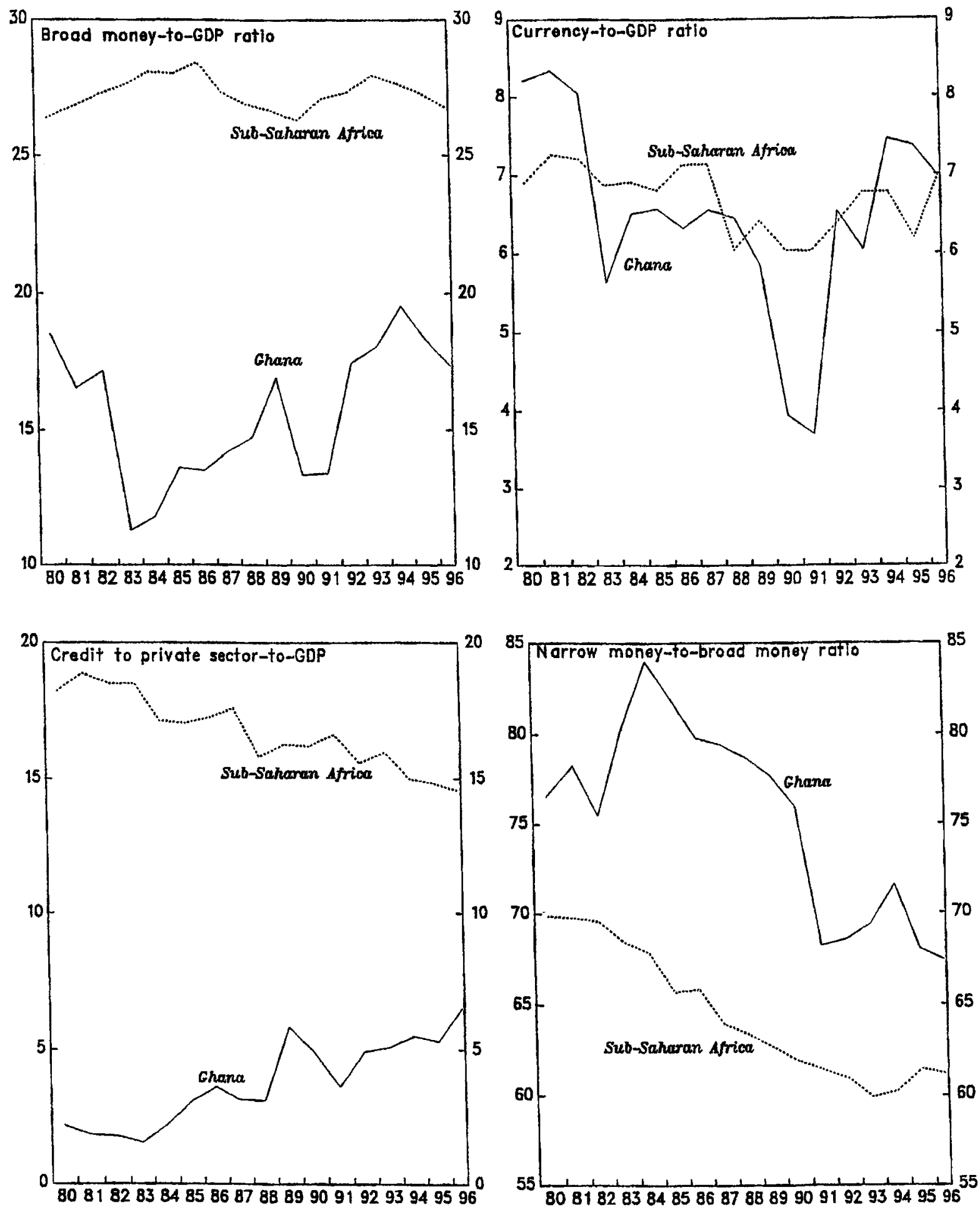

Sources: Data provided by the Ghanalan authoritles; and st off estimetes.

1/ Data for 5ub-Sahara Africo ore unweighted overages. 
33. Interest rates have not been very responsive to changes in the macroeconomic environment. In 1995, the average inflation rate was about 50 percent, while lending rates were about 40 percent and saving rates barely reached 30 percent-both negative in real terms. In 1998, inflation more than halved but lending rates have remained around 30-40 percent. The fact that state owned banks with high shares of nonperforming loans still represent a significant segment of the financial market, may be one of the explanations for the behavior of interest rates. ${ }^{12}$ Moreover, state-owned banks have high operational costs and a large portfolio of nonperforming loans, which increase the share of fixed costs. Demand deposits, which represent 33 percent of total deposits, yield no or little interest, implying that a downward adjustment in the interest rate paid on deposits would only marginally decrease banks' cost of funds. This cost structure suggests that a decline in interest rates is likely to reduce bank spreads, possibly to levels that will make them unprofitable. Therefore, these banks would be expected to resist as much as possible a decline in interest rates.

34. Another feature of the banking system in Ghana is its high dollarization: 32 percent of total assets and 27 percent of deposits were denominated in foreign currency in June 1998. For borrowers, the main attraction of foreign currency credits is the interest rate, which is much lower than in domestic currency loans; in July 1998, the interest rates on foreign currency loans were 27-36 percentage points lower than those on domestic currency loans, with the spread exceeding any reasonable expectation of devaluation. Lenders also have an incentive to lend in foreign currency as they need to maximize the rate of return on the resources obtained from foreign exchange deposits. Depositors still maintain a high share of their deposits in foreign currency both because of positive real interest rates ${ }^{13}$ and because of a continued lack of confidence in the sustainability of appropriate economic policies.

35. The dollarization of the banking system in Ghana has led the supervisory authorities to monitor closely the foreign exchange exposure of individual banks to ensure that they are not taking excessive risk. Available information seems to indicate that the net open positions of many of the Ghanaian banks are high. ${ }^{14}$ A rough estimate for the consolidated banking system showed the net open position to be around 50 percent of shareholders' funds, though for the public sector banks as a whole it averages about twice as much as the average for mixed and private ownership. The private sector banks as a whole have only a slightly more comfortable open foreign currency position of about 30 percent of shareholders' funds. Therefore, the banking system in Ghana is very vulnerable to exchange rate movements that could result in

\footnotetext{
${ }^{12}$ Another reason is that the government is still placing significant amounts of government securities to finance its deficit.

${ }^{13}$ Interest rates on foreign currency deposits range around 2-3 percent.

${ }^{14} \mathrm{Calculated}$ as the ratio of the difference between assets and liabilities denominated in foreign currency to shareholders' funds.
} 
large losses in relation to shareholders' funds. The authorities are considering amending and reissuing foreign exposure regulations before the end of 1998.

\section{How Far Have the Reforms Gone?}

36. The current structure of the banking system suggests that some progress has been achieved since the first wave of reforms; nevertheless, much remains to be done. Banks seem to rely excessively on income from government securities, with loans to the private sector still representing a relatively small portion of their assets. At an early stage in the banking reforms the supervisory authorities eliminated nonperforming loans from the balance sheet of the banking system at great cost; yet, by mid-1998, the supervisory authorities were again confronted with a banking system with an unacceptably large share of nonperforming loans.

37. In mid-1998, the average share of nonperforming loans in total credits in the banking system was still around 27 percent, only 14 percentage points below the levels early in the first wave of banking reforms (see Table 4) ${ }^{15}$ It is true, however, that if one abstracts from three small banks with serious problems, the share of nonperforming loans declines to about 14 percent for the whole sector, a more manageable ratio, particularly since the supervisory authorities have kept the pressure on banks to maintain adequate provisions against default risks. In addition, the bulk of nonperforming assets currently in the system does not relate to credit to state-owned enterprises, a widespread problem in the first wave of reforms.

38. The fact that state-owned banks have a significantly higher share of nonperforming loans than private banks suggests that the slow pace of the divestiture program may have endangered the success of the reforms and may now reduce significantly, or even eliminate, government proceeds from the divestiture. In particular, the situation of some state-owned banks is such that a liquidation may prove to be a simpler and more economical way to restore the banking system to full health.

39. On the positive side, the restructuring program has tended to increase the average capitalization of banks; in particular, the swap of bad loans and the enforcement of new regulations in the early nineties has been successful in improving the capital adequacy ratios in the system. Except for three banks that are experiencing problems, all other banks meet or exceed the minimum capital requirements, which is 6 percent of assets. ${ }^{16}$

\footnotetext{
${ }^{15}$ The nonperforming loans removed at the time of the restructuring represented about 41 percent of total credit extended to state owned enterprises and private firms. See World Bank (1994).

${ }^{16}$ The calculation of the minimum capital requirement does not follow the Basle Committee recommendations, although in practice it has resulted in levels of minimum capital in excess of the Basle Committee's 8 percent risk-weighted assets-to-capital ratio.
} 
40. The regulatory framework developed in 1989 , while for the greater part in line with the Basle Committee core principles, needs to be implemented with greater consistency and vigor. Penalties for noncompliance were stated in nominal terms and are now negligible after years of high inflation. In particular, the 1989 law does not provide for prudential regulations regarding foreign currency exposure, which, as mentioned above, have become a serious concern. In addition, the enforcement of the banking law regulations by the supervisory authorities has not been as strict as it could have been: penalties for noncompliance have at times been suspended on an ad hoc basis. For example, several banks are presently in noncompliance with single customer exposure limits. Moreover, improvements in the payment system have been slow, leaving the system open to fraud as shown in the 1997 A-Life incident. However, the authorities have recently renewed their efforts to modernize the payment systems by standardizing checks and using magnetic ink to permit the automation of most clearing procedures.

41. Finally, the revision of the legal framework has not succeeded in increasing significantly the speed with which commercial banks can recover losses associated with bad credit through the judicial system, thus placing an important obstacle to the development of the banking business.

\section{E. Lessons Learned and Next Steps}

42. The early banking reforms of Ghana were considered one of the more successful in Africa. ${ }^{17}$ Yet, the banking system is still not as healthy and competitive as one would expect six years after these reforms were completed. The main problem with the reforms was that the divestiture program, which was seen as the second phase of the reforms, has progressed very slowly. Therefore, most state-owned banks returned to the same practices that had been at the root of the problems faced by the banking system in the eighties: excessive political influence, weak management, backward information and accounting systems, inadequate credit approval procedures, and poor internal controls. As a result, nonperforming loans increased once again, further slowing down the divestiture process by reducing the attractiveness of these banks to potential investors.

43. To prevent the perpetuation of the existing problems with the banking system, a number of measures could be taken. First and foremost, the divestiture process needs to be accelerated and completed. This process should include the privatization, merger or liquidation of all state-owned banks and the complete divestiture of the shares of both the government and the central bank in all commercial banks. The government should also ensure that the shares held by SSNIT remain a minority (passive) investment.

\footnotetext{
${ }^{17}$ World Bank (1994).
} 
44. Second, banks not meeting the minimum capital requirement, even if government owned, should be liquidated, if the shareholders are unable to recapitalize the bank. This may require the adoption of a more formal exit policy for financial institutions.

45. Third, bank profits for well-managed banks are high, so competition should be encouraged by allowing new, professionally managed banks to enter the market.

46. Fourth, prudential regulations should be updated and their enforcement strengthened. In particular, the implementation of an adequate foreign exchange exposure limits is urgent. Regulations on single creditor risk needs also to be enforced. Onsite and offsite supervision needs to be reinforced through close monitoring of banking procedures. The use of external auditors, as a complement to supervision by the central bank, may also be considered. Penalties for noncompliance with prudential regulations need to be made more meaningful and fully enforced.

47. Finally, the government needs to improve the environment for banking business. In addition to ensuring a stable macroeconomic environment, the government will need to strengthen the legal framework and the judicial system to facilitate recovery of nonperforming loans, while protecting borrowers from unfair practices. The payment system will also need to be modernized to prevent fraud and facilitate financial transactions. 


\section{References}

Dziobek, C. and C. Pazarbašioğlu, 1997, "Lessons from Systemic Bank Restructuring: A Survey of 24 Countries," IMF Working Paper No. 161 (Washington: International Monetary Fund).

Kapur, I., M. Hadjimichael, P. Hilbers, J. Schiff, and P. Szymczac, 1991, "Ghana: Adjustment and Growth," 1983-91, IMF Occasional Paper No. 81 (Washington: International Monetary Fund).

Kwaku Sowa Nii, 1997, "Central Banking and Monetary Management in Ghana," CEPA Research/Working Paper No. 9.

World Bank, 1994, "Ghana: Financial Sector Review: Bringing Savers and Investors Together," Report No. 13423 - GH (Washington: World Bank). 


\section{TARIFF REFORM IN GHANA ${ }^{18}$}

\section{A. Review of Tariff Policy}

48. The trade and tariff system in Ghana has undergone substantial change since the launching of the Economic Recovery Program (ERP) in 1983 and the implementation of several liberalization programs through the mid-1990s. The index of aggregate trade competitiveness for Ghana is currently in the moderate range. ${ }^{19}$ (International Monetary Fund, 1997). After briefly reviewing past developments, this chapter presents the current tariff system in detail and examines the implications of reducing zero rating and exemptions, and lowering the top rate.

\section{Recent Developments in Tariff Policy}

49. The launching of the ERP initiated a significant break from the protectionist trade policies that had prevailed for many years. An important objective was to replace an economic development plan based on import substitution with a growth strategy based on export expansion. By liberalizing trade and submitting the economy to external competition, industry was expected to develop in sectors in which Ghana had a comparative advantage and, therefore, good prospects for growth through exports in the world market. In order to allow competition to work, the government needed to remove restrictions and distortions impeding trade and permit the private sector to respond to market incentives.

50. By 1983, constraints on trade were considerable as Ghana had become one of the most protectionist countries in the world (Edwards, 1990). During the ERP period, Ghana's trade and tariff system was simplified by the steady implementation of measures to remove quantitative restrictions on imports, abolish import licensing, remove limitations on the availability of foreign exchange, move away from a fixed exchange rate, and eliminate price controls. In 1983, the existing tariff system was replaced by a predominantly uniform tariff structure with a rate of 30 percent. Although the uniform tariff rate was replaced by a four-tiered cascading structure in 1986, rates in each tier were steadily lowered over the course of the ERP.

51. The performance of the manufacturing sector improved markedly with the trade and tariff reforms under the ERP. Prior to the ERP, during the peak period of the import substitution program in 1978-83, value added of the manufacturing sector declined at an annual average rate of 12 percent. Over the $1984-93$ period, real value added in manufacturing grew at an average rate of about 8 percent annually. A disaggregated study of

\footnotetext{
${ }^{18}$ Prepared by Roman Arjona-Gracia, Anthony Pellechio, and Allan Crego (World Bank).

${ }^{19}$ International Monetary Fund, 1997. Ghana's restrictiveness index was 4 on a scale of 0-10.
} 
the impact of trade liberalization found that its objectives were achieved (Biggs and Shah, 1997). Specifically, exporting firms grew substantially, benefiting from higher prices of their output and lower costs of inputs. Firms producing nontradable goods increased production, while those competing with imports, especially in textiles, contracted.

52. Decreases in tariff rates over the ERP period substantially reduced Ghana's effective tariff rate (Figure 2). In the period 1978-84, before trade liberalization began under the ERP, the effective import tariff rate was 17 percent (Farhadian-Lorie and Katz, 1988). The trade liberalization program came into effect in 1986 , and, by 1988 , the effective tariff rate had fallen to 7.4 percent. Through 1992, the effective import tariff rate continued to decline, largely from the lowering of statutory rates. Between 1992 and 1996, the effective rate fluctuated. In 1993, an unusually strong demand for imported consumer goods in the last quarter raised the average effective tariff rate for the year. In 1994, the effective rate returned to its average level in 1990-92. In 1995, it rose when import tariffs were collected along with the new value-added tax (VAT) on imports and the tax base was broadened by limiting exemptions. However, after the VAT was rescinded and the list of exempted imports was expanded again in 1996, the effective tariff rate declined to about 5 percent, its lowest level so far.

53. The government's 1994 budget simplified the tariff structure, enacting three ad valorem rates of 0,10 , and 25 percent of the c.i.f. value of imports. However, specific duties were applied to over 100 commodities at the eight-digit code level in the harmonized system, as well as to many textiles and garments. These specific duties were set up as alternatives to the domestic sales tax, with the higher of the two being applied. In addition, sales tax rates on imported goods were set at 0,15 , and 35 percent.

54. Taxes on international trade and, more specifically, import tariffs, have been and continue to be a major source of government revenue in Ghana (Figure 3). In 1986, the share of trade taxes in total revenue declined following the replacement of the prevailing uniform tariff rate of 30 percent by a cascading structure with lower rates. From 1989, the average share has fluctuated in the 25-30 percent range. The share of import tariffs in total tax revenue has followed a similar pattern, fluctuating in the 15-20 percent range since 1989.

55. Simple and import-weighted averages of statutory tariff rates for Ghana and a sample of other African countries are presented in Figure $4 .^{20}$ Ghana's average tariff rates are below those in the other countries, with the import-weighted average significantly lower than the rest of the sample. As shown in the next section, this difference follows primarily from the extensive zero rating and the erosion of the tariff base by exemptions in Ghana.

\footnotetext{
${ }^{20}$ The simple and import-weighted averages are calculated using the formula $\sum_{i} w_{i} t_{i} / W$ and $w=\sum_{i} w_{i}$ where $i$ indexes the statutory tariff rates and $w_{i}$ equals the number of lines in the tariff schedule at rate $t_{i}$ for the simple averages, and the c.i.f. value of imports at rate $t_{i}$ for the import-weighted averages.
} 
Figure 2. Ghana: Effective Rate of Tariff and Sales Tax on Imports , 1988-96

(In percent)

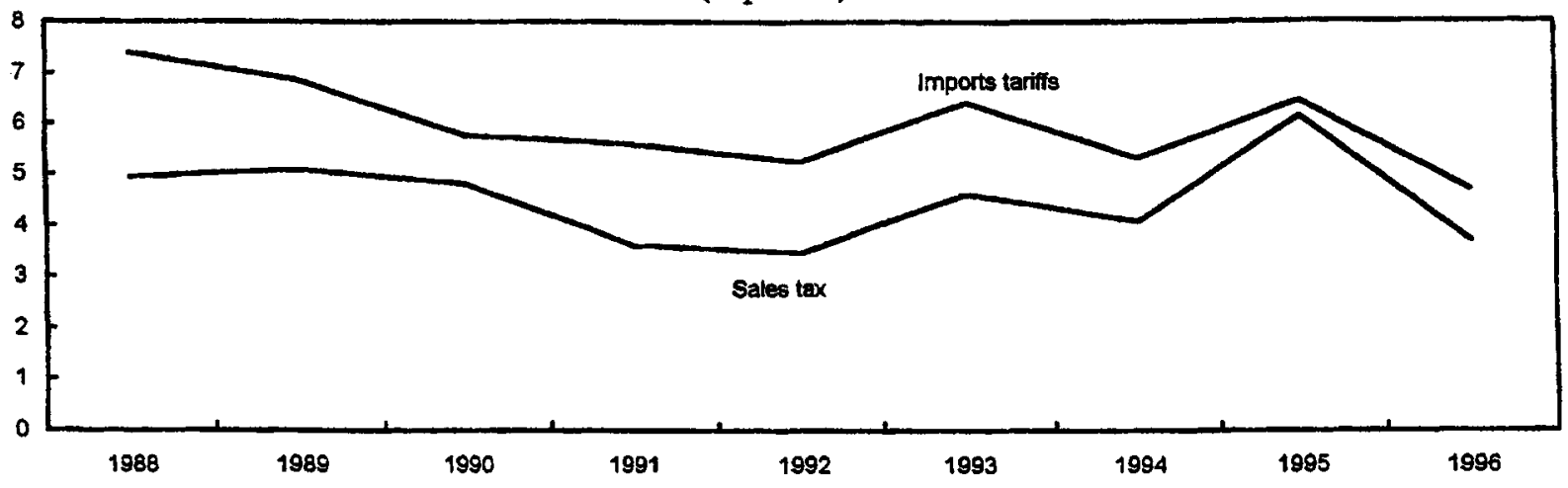

Figure 3. Ghana: Share of Trade Taxes and Imports Tariffs in Total Tax Revenue (In percent), 1986-96

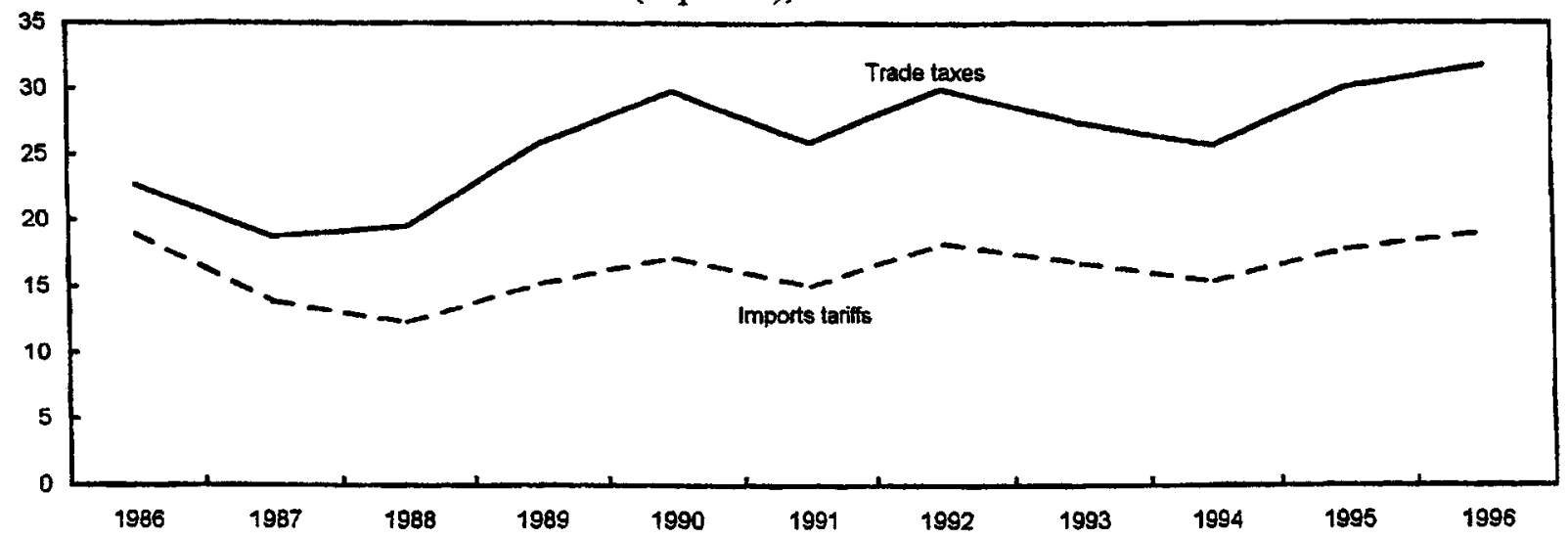

Figure 4. Selected African Countries: Statutory and Import-Weighted Averages of Tariff Rates

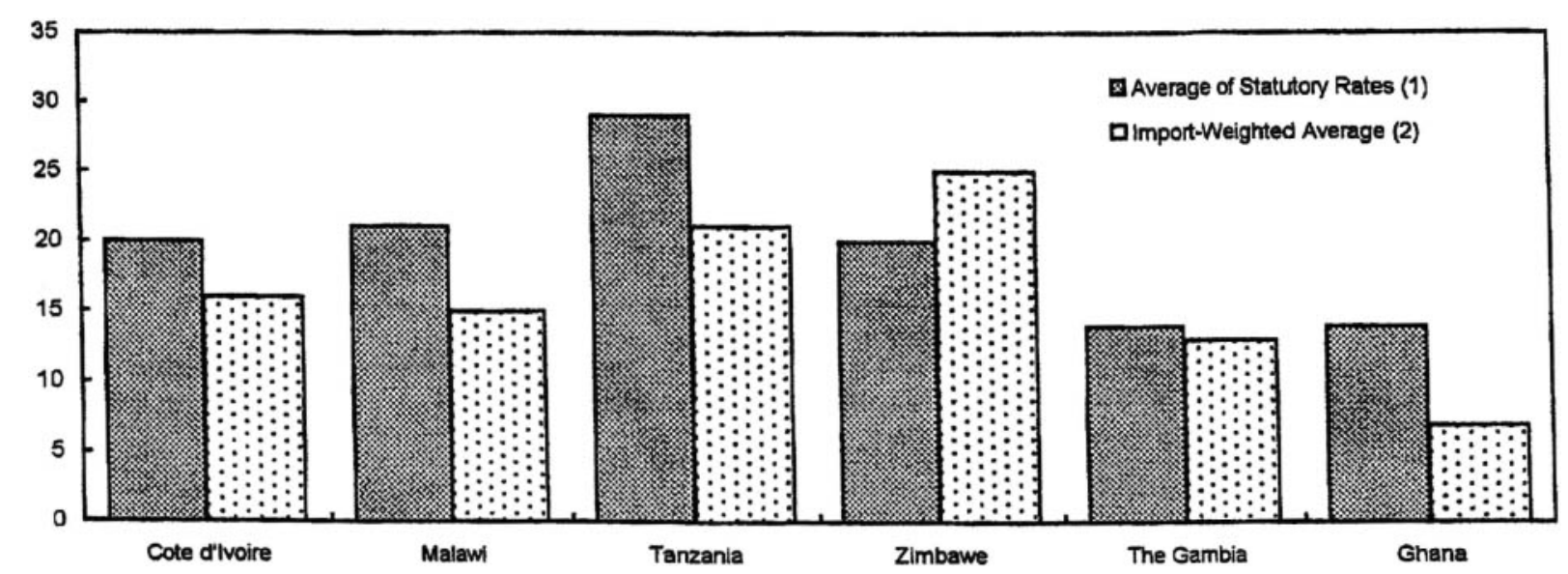

1/ Data for 1994, from Kirmani (1994)

2/ Data for 1997, from Aksoy (1998), and IMF staff calculations for Ghana and the Gambia 


\section{Key Features of the Current Tariff System}

56. Ghana's current tariff structure is relatively simple, with four rates and no quantitative restrictions. The system was introduced in 1994 with three rates of 0,10 , and 25 percent, with the objective of enhancing uniformity and reducing dispersion. A 5 percent rate was added in 1998 to facilitate shifting zero-rated goods to a positive rate. The current system also incorporates a 15 percent sales tax. In addition, the tariff system has a significant number of exemptions. The problems created by extensive use of zero rating and exemptions have given rise to calls for further reform of the tariff system.

\section{Statutory and effective tariff rates}

57. Table 6 summarizes Ghana's tariff system by applying its rate structure and exemptions to import data for $1997 .^{21,} 22$ It presents for each rate the number of lines in the tariff schedule, the number of lines with actual imports, the share in total c.i.f. import value, and the statutory and effective rates for the import tariff and sales, and other taxes on imported goods.

58. Zero-rated goods comprise a large share, nearly 47 percent, of import value. The share of goods imported at the 10 percent rate is almost 38 percent. Goods imported at the 5 percent and 25 percent rates together account for only about 15 percent of imports.

${ }^{21}$ The analysis in the remainder of this study is based on the Automated System for Customs Data Management (ASYCUDA) data set provided by the Ghana Statistical Service. This data set consists of all transactions in 1997 at the three main ports in Ghana (Tema, Kotoka International Airport, and Takoradi) and covers more than 95 percent of the total imports. Aggregate figures derived from this data set differ in value from similar figures reported by the customs administration. These differences are under review by Fund and Bank staff in collaboration with Ghanaian authorities. The outcome of this review is not expected to alter the main empirical results and conclusions of this study as it relies on statistics calculated as ratios or shares whose values are unlikely to change significantly.

\footnotetext{
${ }^{22}$ The analysis excludes petroleum products which are subject to special excises and fees, but not to either specific or ad valorem import tariffs. All petroleum product imports take place at the Tema Oil Refinery, the state oil refinery that has a monopoly in the importation of petroleum products.
} 


\begin{tabular}{|c|c|c|c|c|c|c|c|c|c|}
\hline \multicolumn{10}{|c|}{ Table 6. Ghana: Statutory and Effective Tax Rates on Imports } \\
\hline \multicolumn{5}{|c|}{ Features } & \multicolumn{5}{|c|}{ Rates (in percent) } \\
\hline $\begin{array}{l}\text { Rates } \\
\text { (in } \\
\text { percent) }\end{array}$ & & $\begin{array}{l}\text { Number of } \\
\text { lines in } \\
\text { schedule }\end{array}$ & $\begin{array}{l}\text { Number } \\
\text { of lines } \\
\text { with } \\
\text { actual } \\
\text { imports }\end{array}$ & $\begin{array}{c}\text { Import } \\
\text { share } \\
\text { (in } \\
\text { percent) }\end{array}$ & Import & $\underset{\operatorname{tax}}{\text { Sales }}$ & $\begin{array}{l}\text { Other } \\
\text { taxes }\end{array}$ & $\begin{array}{l}\text { Total } \\
\text { taxes }\end{array}$ & $\begin{array}{c}\text { Difference } \\
\text { between } \\
\text { statutory } \\
\text { and } \\
\text { effective } \\
\text { rates }\end{array}$ \\
\hline \multirow[t]{2}{*}{0} & Statutory & 785 & 673 & 46.8 & 0.0 & 0.0 & 0.7 & 0.8 & \\
\hline & Effective & & & & 0.0 & 0.0 & 0.7 & 0.7 & 0.0 \\
\hline \multirow[t]{2}{*}{5} & Statutory & 106 & 73 & 3.3 & 5.0 & 0.0 & 0.0 & 5.0 & \\
\hline & Effective & & & & 0.7 & 0.0 & 0.0 & 0.7 & 4.3 \\
\hline \multirow[t]{2}{*}{10} & Statutory & 2,605 & 1,884 & 37.9 & 10.0 & 12.2 & 1.3 & 24.9 & \\
\hline & Effective & & & & 5.5 & 4.5 & 1.2 & 11.5 & 13.4 \\
\hline \multirow[t]{2}{*}{25} & Statutory & 2,447 & 1,813 & 12.0 & 25.0 & 15.0 & 3.9 & 48.7 & \\
\hline & Effective & & & & 13.6 & 7.9 & 1.3 & 24.1 & 24.6 \\
\hline \multirow[t]{2}{*}{ Total } & Statutory & 5,973 & 4,443 & 100.0 & 6.9 & 6.9 & 1.4 & 15.8 & \\
\hline & Effective & & & & 3.7 & 2.8 & 1.0 & 7.6 & 8.2 \\
\hline
\end{tabular}

59. The effective tariff rate corresponding to each positive statutory rate is much lower because of exemptions-specifically, 0.7 percent at the 5 percent statutory rate, 5.5 percent at the 10 percent rate, and 13.6 percent at the 25 percent rate. The effective sales tax rate is also considerably lower than the simple average of the statutory sales tax rates applied at the 10 and 25 percent tariff rates (the sales tax is not applied at the 5 percent tariff rate). In particular, the effective sales tax rate is 4.5 percent for an average statutory sales tax rate of 12.2 percent at the 10 percent tariff rate and 7.9 percent for an average statutory sales tax rate of 15 percent at the 25 percent tariff rate.

60. Taxes on imports other than tariffs and sales taxes show little or no variation between the statutory and effective rates at each tariff rate, with one exception. At the 25 percent tariff rate, other taxes have a 3.9 percent statutory rate but an effective rate of 1.3 percent, indicating that exemptions have a significant impact on other taxes at the top tariff rate.

\section{The system of exemptions}

61. A comparison of the revenue collected by the customs administration and the potential revenue that could have been collected if there were no exemptions reveals the following:

- The total tax revenue foregone to exemptions amounts to approximately 52 percent of potential revenue, or 8.2 percent of the total c.i.f. value of imports. 
- Elimination of exemptions would more than double total revenue collection at the 10 and 25 percent rates. At the 5 percent rate, elimination of exemptions would increase revenue collection from 0.7 percent of total revenue to 5 percent.

62. Certain exemptions are required by regional and international agreements, such as the ECOWAS Protocol, Geneva Convention, and donor-funded contracts. They cannot be altered unilaterally by the government and are not subject to domestic tariff policy considerations alone.

63. Fifteen different programs of exemption from import tariffs are currently available. The share of the total c.i.f. value of imports for the seven main exemption regimes, as well as their share of the total revenue loss generated by all exemptions, is presented in Table 7.

\begin{tabular}{|lcc|}
\hline \multicolumn{3}{|c|}{$\begin{array}{c}\text { Table 7. Ghana: Share of Imports by Main Exemption Regimes } \\
\text { and Associated Revenue Loss }\end{array}$} \\
\hline Regime & Import Share & $\begin{array}{c}\text { Share of Total } \\
\text { Revenue Loss }\end{array}$ \\
\hline Ministry of Finance & 12.8 & 36.7 \\
Mining and Minerals & 7.2 & 16.7 \\
Commission & 3.2 & 10.5 \\
Volta Aluminum Company & 2.1 & 9.0 \\
Diplomatic privileges & 4.4 & 8.5 \\
Ghana Investment Centre & 9.5 & 7.3 \\
Registered manufacturers & 1.4 & 4.8 \\
National Revenue Secretariat & 40.5 & 93.4 \\
\hline Total & & \\
\hline
\end{tabular}


64. The exemption system has the following features:

- The seven main regimes produce 93.4 percent of the total revenue loss from exemptions. The exemptions listed under the Ministry of Finance account for over 36 percent of the total loss, over twice the loss from the next largest regime. ${ }^{23}$

- A large share of the total loss is not necessarily associated with a large import share. Specifically, the regimes for the Mining and Minerals Commission and the Volta Aluminum Company (VALCO) generate 16.7 percent and 10.5 percent of the total revenue loss but have relatively small import shares of 7.2 percent and 3.2 percent, respectively. ${ }^{24}$

65. The composition of imports in the main exemption regimes, as shown in Table 8 , reveals the following:

- Exemptions do not appear to be based on the economic use of the commodities under each regime.

- For most regimes, a few commodities have relatively large shares of the revenue loss under a particular regime; the rest of the commodities have small shares, under 1 percent of total revenue loss for most items. For example, imports of aluminum oxide account for 37.5 percent of the total revenue loss under the VALCO regime; transmission and reception equipment, 18.3 percent of the loss of the National Revenue Secretariat (NRS) regime; and instruments for physical or chemical analysis, 12.3 percent of the loss under the Ghana Investment Centre.

\footnotetext{
${ }^{23} \mathrm{It}$ is important to note that the Ministry of Finance has no discretionary powers to grant exemptions. Exemptions classified under Ministry of Finance cover exemptions from all other ministries, departments, and agencies under various contractual agreements. They also cover nongovernmental organizations, as well as exemptions granted by parliament. Only parliament has the power to grant exemptions under the Constitution of Ghana.

${ }^{24}$ With regard to VALCO, the Government of Ghana is bound by the Master Agreement that was signed in 1964.
} 
Table 8. Ghana: Distribution of Main Imports by Exemption Regimes and Associated Revenue Loss Due to the Exemptions System

\begin{tabular}{|c|c|c|c|c|}
\hline Regime & $\begin{array}{l}\text { Hammonized } \\
\text { System } \\
\text { Code }\end{array}$ & Commodity & $\begin{array}{l}\text { Regime } \\
\text { Loss }^{1}\end{array}$ & $\begin{array}{l}\text { Total } \\
\text { Loss }^{2}\end{array}$ \\
\hline \multirow[t]{9}{*}{ 1. Ministry of } & 852520 & Transmission and reception apparatus & 7.6 & 3.0 \\
\hline & 380810 & Insecticides, rodenticides, herbicides, etc. . & 4.9 & 1.9 \\
\hline & 902780 & Instruments for physical or chemical anaiysis & 3.7 & 1.5 \\
\hline & 854420 & Coaxial cables & 3.3 & 1.3 \\
\hline & 852790 & Radio-telephonic apparatus & 2.8 & 1.1 \\
\hline & 630510 & Sacks and bags for packing & 2.6 & 1.0 \\
\hline & 100190 & Wheat and meslin & 2.4 & 0.9 \\
\hline & 730719 & Tube or pipe fittings of iron and steel & 2.3 & 0.9 \\
\hline & 930330 & Sporting, hunting, or target-shooting rifles & 2.3 & 0.9 \\
\hline \multirow[t]{5}{*}{$\begin{array}{l}\text { 2. Mining and } \\
\text { Minerals } \\
\text { Commision }\end{array}$} & 732611 & Grinding balls and similar articles for mills & 9.3 & 1.7 \\
\hline & 730890 & Structures of iron and steel & 8.2 & 1.5 \\
\hline & 283711 & Cyanides and cyanide oxides of sodium & 6.3 & 1.1 \\
\hline & 841391 & Pumps for liquids & 4.3 & 0.8 \\
\hline & 722880 & Other bars and rods of other alloy steel & 4.2 & 0.7 \\
\hline \multirow[t]{5}{*}{$\begin{array}{l}\text { 3. Volta } \\
\text { Aluminum } \\
\text { Company }\end{array}$} & 281820 & Aluminum oxide & 37.5 & 4.2 \\
\hline & 271312 & Petroleum coke, bitumen, and residues of oils & 14.3 & 1.6 \\
\hline & 281310 & Sulfides of nonmetals & 6.9 & 0.8 \\
\hline & 281810 & Artificial corundum & 6.7 & 0.7 \\
\hline & 282612 & Fluorides and complex fluorine saits & 4.4 & 0.5 \\
\hline \multirow[t]{5}{*}{$\begin{array}{l}\text { 4. Diplomatic } \\
\text { Privileges }\end{array}$} & 151519 & Other vegetable fats and oils & 30.5 & 3.0 \\
\hline & 220890 & Undenaturated ethyl alcohol & 19.1 & 1.8 \\
\hline & 220300 & Beer made from malt & 12.9 & 1.3 \\
\hline & 220421 & Wine of fresh grapes & 12.7 & 1.2 \\
\hline & 100110 & Durum wheat & 2.9 & 0.3 \\
\hline \multirow[t]{5}{*}{$\begin{array}{l}\text { 5. Ghana } \\
\text { Investment } \\
\text { Center }\end{array}$} & 902780 & Instruments for physical or chemical analysis & 12.3 & 1.1 \\
\hline & 852731 & Reception apparatus for radio telephony & 5.1 & 0.5 \\
\hline & 851730 & Telephonic or telegraphic switching apparatus & 4.6 & 0.4 \\
\hline & 852520 & Transmission and reception apparatus & 4.2 & 0.4 \\
\hline & 847330 & Parts and accessories for HS $84.69-84.72$ & 3.7 & 0.3 \\
\hline
\end{tabular}


Table 8. Ghana: Distribution of Main Imports by Exemption Regimes and Associated Revenue Loss Due to the Exemptions System

\begin{tabular}{|c|c|c|c|c|}
\hline Regime & $\begin{array}{l}\text { Harmonized } \\
\text { System } \\
\text { Code }\end{array}$ & Commodity & $\begin{array}{l}\text { Regime } \\
\text { Loss }{ }^{1}\end{array}$ & $\begin{array}{l}\text { Total } \\
\text { Loss }^{2}\end{array}$ \\
\hline \multirow[t]{5}{*}{$\begin{array}{l}\text { 6. Registered } \\
\text { manufacturers }\end{array}$} & 281810 & Artificial corundum & 6.0 & 0.5 \\
\hline & 330210 & Mixtures of odoriferous substances & 4.3 & 0.3 \\
\hline & 390210 & Polyethylene & 4.2 & 0.3 \\
\hline & 390110 & Polyethylene & 4.2 & 0.3 \\
\hline & 110710 & Malt & 4.0 & 0.3 \\
\hline \multirow[t]{5}{*}{$\begin{array}{l}\text { 7. National } \\
\text { Revenue } \\
\text { Secretariat }\end{array}$} & 852520 & Transmission and reception apparatus & 18.3 & 0.9 \\
\hline & 630510 & Sacks and bags for packing & 8.2 & 0.4 \\
\hline & 320890 & Paints and varnishes & 7.6 & 0.4 \\
\hline & 100190 & Durum wheat & 4.6 & 0.2 \\
\hline & 721690 & Angles, shapes, and sections of iron and steel & 4.4 & 0.2 \\
\hline
\end{tabular}


66. Table 9 examines the revenue loss from exemptions by broad categories of imports. Nuclear reactors, mineral fuels, and vehicles comprise nearly half of the total import value. However, some of the main sources of revenue losses-electrical machinery, articles of iron and steel, and inorganic chemicals-do not have large import shares.

\begin{tabular}{|c|c|c|c|}
\hline \multicolumn{4}{|c|}{$\begin{array}{l}\text { Table 9. Ghana: Ranking of Main Two-Digit Commodity Code Imports } \\
\text { by Import Share and Associated Revenue Loss Owing to Exemptions } \\
\text { (In percent) }\end{array}$} \\
\hline $\begin{array}{l}\text { HS-2 } \\
\text { Code }\end{array}$ & Commodities & Import Share & $\begin{array}{l}\text { Share of Total } \\
\text { Revenue Loss }\end{array}$ \\
\hline 84 & Nuclear reactors, boilers and parts thereof & 18.2 & 6.2 \\
\hline 87 & Vehicles other than railway or tramway & 15.9 & 2.8 \\
\hline 27 & Mineral fuels, mineral oils and byproducts & 8.9 & 2.0 \\
\hline 85 & $\begin{array}{l}\text { Electrical machinery and equipment and parts } \\
\text { thereof }\end{array}$ & 8.1 & 20.9 \\
\hline 98 & Special classification provisions & 6.4 & 0.1 \\
\hline 94 & $\begin{array}{l}\text { Furniture; furnishings; various signs; } \\
\text { prefabricated buildings; etc. }\end{array}$ & 4.5 & 0.9 \\
\hline 28 & Inorganic chemicals & 3.3 & 9.2 \\
\hline 73 & Articles of iron and steel & 3.2 & 9.1 \\
\hline 90 & Optical apparatus & 2.6 & 5.5 \\
\hline
\end{tabular}

67. Table 10 presents imports and revenue loss distributed by main uses of imports. The largest losses arise from exemptions on capital goods and intermediate goods, which account for approximately 32 percent and 44 percent of total loss, respectively. The loss from exemptions for consumer goods is almost 18 percent. 


\begin{tabular}{|c|c|c|}
\hline \multicolumn{3}{|c|}{$\begin{array}{l}\text { Table 10. Ghana: Sector Classification of Imports by Revenue Loss } \\
\text { Owing to the Exemptions System } \\
\text { (In percent) }\end{array}$} \\
\hline Sectors & Import Share & $\begin{array}{l}\text { Share of Total } \\
\text { Revenue Loss }\end{array}$ \\
\hline Agriculture & 4.5 & 5.3 \\
\hline Capital Goods & 41.2 & 31.6 \\
\hline Consumer Goods & 17.7 & 17.9 \\
\hline Intermediate Goods & 19.7 & 44.4 \\
\hline Mining & 6.1 & 0.2 \\
\hline Unclassified & 10.8 & 0.7 \\
\hline
\end{tabular}

\section{B. Directions for Further Reforms}

68. As Ghana continues its efforts to achieve sustainable growth, the government will need to carry out tariff reforms to prevent misallocation of resources and loss of efficiency owing to distortionary effects of the tariff structure. However, trade tariffs still represent a significant source of revenue, and, therefore, any change in the tariff system needs to take into account its effects on revenue. The analysis of the present tariff structure in Ghana highlights three important points: (a) the widespread use of zero rates, in many cases without economic justification; (b) the generous use of exemptions, which reduces transparency and creates discriminatory treatment of users; and (c) the relatively high top rate of 25 percent, which may need to be reduced for Ghana to be in line with the tariff structure recommended for countries in the West Africa Economic and Monetary Union and, therefore, in a competitive position for foreign investment. This section examines several reform packages proposed with these points in mind to gauge their impact on effective tariff rates and revenue.

\section{Options for Tariff Reforms}

69. Reform packages can take many forms, and it would be impossible to cover all of them. The purpose of the analysis in this section is not to advocate a specific package of tariff reforms, but to explore the implications of a limited number of reform options on the effective tariff rate and tariff revenues. In particular, we examine the likely effects of various combinations of three elements:

- a reduction in the top tariff rate from 25 percent to 20 percent;

- a reduction in the value of tariff exemptions to one-half of their current level, with exemptions for sales tax and other taxes remaining at their current level; and 
- $\quad$ an increase in the tariff on zero-rated consumer goods to 5 percent.

70. These three elements will be combined into six different options in an effort to identify some trade-offs among revenue loss, removal of distortions, and reduction of tariff dispersion. In order to simplify the examination of their impact, the demand for imports is assumed to remain unaffected by changes in the tariff system. The six options, as shown in Table 11, are the following:

- Option 1, which reduces the value of tariff exemptions by one-half;

- Option 2, which reduces the value of tariff exemptions by one-half and the top tariff rate from 25 percent to 20 percent;

- Option 3, which moves consumer goods from the zero-rated category to the 5 percent rate;

- Option 4, which applies the 5 percent rate to zero-rated consumer goods and reduces the top tariff rate from 25 percent to 20 percent;

- Option 5, which lowers the value of tariff exemptions by one-half and applies the 5 percent rate to zero-rated consumer goods; and

- Option 6, which reduces the value of tariff exemptions by one-half, applies the 5 percent rate to zero-rated consumer goods, and lowers the top tariff rate from 25 percent to 20 percent.

\begin{tabular}{|llll|}
\hline \multicolumn{3}{c}{ Table 11. Ghana: Main Features of Reform Options } \\
\hline Option & Zero-Rating & Tariff Exemptions & $\begin{array}{c}\text { Top } \\
\text { Rate } \\
\text { (in percent) }\end{array}$ \\
\hline Current & Unchanged & Current & 25 \\
Option 1 & Unchanged & Reduced by one-half & 25 \\
Option 2 & Unchanged & Reduced by one-half & 20 \\
Option 3 & Consumer goods & Current & 25 \\
Option 4 & Consumer goods & Current & 20 \\
Option 5 & Consumer goods & Reduced by one-half & 25 \\
Option 6 & Consumer goods & Reduced by one-half & 20 \\
\hline
\end{tabular}




\section{Impact of Tariff Reform Options}

71. This section analyzes the implications of the different tariff reform options listed above on average and effective tariff rates and revenue collection. Table 12 presents the simple and import-weighted averages of import tariff rates under each of the options. Table 13 describes the impact of the tariff reform options on effective tariff rates. Finally, Table 14 describes the effects on revenue.

72. As can be seen from Table 12, the effect of any one of the options being considered is less than 1.5 percentage points in the case of simple average nominal tariffs, and at most about 0.6 of a percentage point in the case of the import-weighted average nominal tariffs. Options 2,4 , and 6 lower both tariff averages: by 1.3-1.5 percentage points for the simple averages, and by $0.4-0.6$ percentage points for the import-weighted averages. Options 3 and 5 increase them marginally. Option 1 leaves the averages unchanged, as it modifies only the existing exemption system.

\begin{tabular}{lrr}
$\begin{array}{c}\text { Table 12. Ghana: Simple and Import-Weighted Averages } \\
\text { of Effective Tariff Rates Under the Reform Options } \\
\text { (In percent) }\end{array}$ \\
\hline System & Simple Average & $\begin{array}{c}\text { Import-Weighted } \\
\text { Average }\end{array}$ \\
\hline Current & 11.15 & 6.94 \\
Option 1 & 11.15 & 6.94 \\
Option 2 & 9.67 & 6.35 \\
Option 3 & 11.33 & 7.09 \\
Option 4 & 9.85 & 6.50 \\
Option 5 & 11.33 & 7.09 \\
Option 6 & 9.85 & 6.50 \\
\hline
\end{tabular}

73. Effective tariff rates are much lower than average statutory tariff rates because of the widespread use of exemptions. As one would expect, the halving of tariff exemptions would significantly increase the effective tariff rates and the reclassification of lines has a more modest impact based on the change in the benefit associated with the reclassified items. The effective tariff rates under each option are presented in Table 13 below. As can be observed, for options that involve halving of the exemptions (options $1,2,5$, and 6), the effect is much 
larger than in those that involve only a reclassification of lines (options 3 and 4). The largest effect occurs in option 5, which not only eliminates half of the exemptions but also reclassifies zero-rated consumer goods, while maintaining the top tariff rate at 25 percent. Option 4 actually results in a small reduction of the average effective tariff rate as the effect of the reduction in the top rate dominates the switching of zero-rated consumer goods to the 5 percent tariff group.

Table 13. Ghana: Effective Tariff Rates Under the Reform Options (In percent)

\begin{tabular}{lccccccc}
\hline \multicolumn{1}{c}{ Rates } & Current & Option 1 & Option 2 & Option 3 & Option 4 & Option 5 & Option 6 \\
\hline O percent & 0.0 & 0.0 & 0.0 & 0.0 & 0.0 & 0.0 & 0.0 \\
5 percent & 0.7 & 2.9 & 2.9 & 1.9 & 1.9 & 3.5 & 3.5 \\
10 percent & 5.5 & 7.7 & 7.7 & 5.5 & 5.5 & 7.7 & 7.7 \\
20 percent & -- & -- & 15.4 & -- & 10.9 & -- & 15.4 \\
25 percent & 13.6 & 19.3 & -- & 13.6 & -- & 19.3 & - \\
Total & 3.7 & 5.3 & 4.9 & 3.8 & 3.5 & 5.5 & 5.0 \\
\hline
\end{tabular}

74. Table 14 below summarizes the impact of the different reform options on revenue and on the losses owing to the exemption system. The main effect of the reform options on tariff revenue comes from the reduction of exemptions. The adoption of any of the options that assume a reduction of exemptions (options $1,2,5$, and 6) generates a gain in revenue ranging from 16 percent to 23 percent of current tariff revenue. Moreover, option 3, which assumes the application of a 5 percent tariff to zero-rated consumer goods, but changes neither the exemptions nor the top rate, shows a 1 percent increase in tariff revenue. The only case that results in a modest reduction (4 percent) in tariff revenue is option 4, which, in addition to the reforms of option 3 , also assumes a decline in the top rate from 25 percent to 20 percent. This latter element has a stronger negative effect on tariff revenue than the effect arising from the reclassification of zero-rated consumer goods to the 5 percent tariff group. 


\begin{tabular}{|lcc|}
\hline \multicolumn{3}{|c|}{$\begin{array}{c}\text { Table 14. Ghana: Effects of Reform Options on Revenue } \\
\text { and Loss Owing to the Exemptions System }\end{array}$} \\
\hline System & $\begin{array}{c}\text { Percent of Current } \\
\text { Revenue }\end{array}$ & $\begin{array}{c}\text { Percent of Current } \\
\text { Loss Due to } \\
\text { Exemptions }\end{array}$ \\
\hline Current & 100 & 100 \\
Option 1 & 121 & 80 \\
Option 2 & 114 & 78 \\
Option 3 & 101 & 101 \\
Option 4 & 96 & 97 \\
Option 5 & 123 & 81 \\
Option 6 & 116 & 78 \\
\hline
\end{tabular}

\footnotetext{
'Aggregate import tariff revenue computed from the data set used in this study is about 25 percent higher than import tariff revenue reported for 1997 in the budget (see footnote 3). Possible reasons for these differences include problems with collection procedures, reporting, and data, and potential discrepancies between tariff calculations in this study and actual calculations. Calculations in this study reflect the application to 1997 data of the tariff structure in 1998, which incorporates changes implemented in March 1998. However, these changes are unlikely to explain the higher revenue computed from the data set.
}

\section{Conclusion}

75. This study highlights the trade-offs between reductions in tariff dispersion, average tariff rates, and tariff revenue. Option 5 brings the maximum positive effect in terms of increasing revenue, and it reduces somewhat tariff dispersion by raising the tariff applicable on zero-rated consumer goods to 5 percent. However, it also results in the largest increase in the average tariff rates, both simple and import-weighted averages. Options 4 and 6 minimize the tariff dispersion while reducing modestly average tariff rates. Option 4 , however, results in the sharpest decline in tariff revenue of all the options examined; option 6 , meanwhile, increases tariff revenue by 16 percent and seems to represent the most balanced reform package among those studied in this chapter.

76. Further reform of the tariff structure needs to be considered in the context of integration with the value-added tax (VAT) being introduced at the end of 1998. Imports will be exempt from the VAT only if they are exempted under the VAT law. Reductions in zerorating and exemptions under the tariff system should be pursued in part to bring the taxation of imports in line with the taxation of consumption embodied in the VAT. 


\section{References}

Aksoy, Ataman, "Preliminary Results from Africa Regional Trade Study," paper presented at the World Bank-International Monetary Fund Workshop (Washington: April 28, 1998).

Biggs, Tyler and Manju Shah, "Trade Reforms, Incentives on Ground and Firm Performance in Ghana," World Bank (Washington: World Bank, July 1997).

Edwards, Sebastian, "On Uniform Import Tariff in Developing Countries," NBER Working Paper No. 3447 (Cambridge, MA, May 1990).

Farhadian-Lorie, Ziba and Menachem Katz, "Fiscal Dimensions of Trade Policy," International Monetary Fund Working Paper No. WP/88/43 (Washington: International Monetary Fund, May 1988).

International Monetary Fund, "Trade Liberalization in Fund-Supported Programs," EBS/97/163 (Washington: International Monetary Fund, August 27, 1997).

Kirmani, Naheed, "International Trade Policies: The Uruguay Round and Beyond, Volume II, Background Papers," World Economic and Financial Surveys (Washington: International Monetary Fund, 1994). 


\section{EXTERNAL COMPETTTIVENESS IN GHANA ${ }^{25}$}

\section{A. Introduction}

77. At the time of its independence in 1957, Ghana was the world's largest producer of cocoa, and its external reserves were equivalent to three years of imports. Ghana was basically an export-driven economy, and its per-capita income was second only to South Africa in subSaharan Africa. After independence, Ghana's leadership changed the economic strategy to emphasize industrialization and import substitution to be achieved through increased government intervention in the economy. By 1982, Ghana's economy had virtually collapsed. The country had depleted its foreign exchange reserves and incurred large external payments arrears. Inflation was running at more than 100 percent, the parallel exchange rate was over 20 times the official rate, and cocoa production had declined to less than one third of its peak. Ghana's external competitiveness was declining precipitously.

78. In 1983, Ghana launched an economic recovery program (ERP) aimed at restoring growth and stabilizing prices. During the period 1983-91, relative prices were realigned to encourage domestic production and exports, a floating exchange rate regime was adopted, and the exchange and trade system was gradually liberalized. Moreover, through 1991, considerable progress was made in reducing macroeconomic imbalances, although inflation remained high and variable. However, in the wake of the 1992 elections, the government granted a large increase in civil service wages, rekindling inflationary pressures despite its subsequent efforts to regain control of the fiscal situation. Since a floating exchange rate regime was in place, the expectation was that any loss of competitiveness from domestic price inflation would be offset by exchange rate movements. The question that this chapter addresses is whether the floating exchange rate system, as well as other policies used by the authorities since 1983, were able to avoid an erosion of Ghana's external competitiveness.

\section{B. Evolution of the Exchange Rate System ${ }^{26}$}

79. Following independence the cedi was pegged to the pound sterling until 1971, when the peg was changed to the U.S. dollar (Box 1). ${ }^{27}$ The collapse of cocoa prices during the sixties forced the government to devalue in December 1971 to moderate the domestic effects of the deterioration in the terms of trade. The government was toppled soon after the devaluation and the cedi was appreciated in steps and then pegged at $\mathbb{C} 1.15$ per US dollar in March 1973. During the remainder of the seventies the authorities were generally unwilling to

\footnotetext{
${ }^{25}$ Prepared by Stefania Fabrizio, with the collaboration of Andrew Bvumbe.

${ }^{26}$ See Kapur, I. and others (1991) for details.

${ }^{27}$ In the period from independence to 1971 , the cedi was devalued only once in mid-1967.
} 


\section{Box 1. Ghana: Exchange Rate Arrangements, 1983-1997}

Initial conditions

- Official exchange rate pegged; the intervention currency was the pound sterling until December 1971; thereafter, the U.S. dollar.

- An active parallel market with rates that differed significantly from the official rate.

- Widespread restrictions on trade and payments.

- Direct allocation of foreign exchange through licenses and import programs.

- Import deposit requirements.

- Bilateral payments arrangement with various countries

Measures after 1983

- Adoption of a real exchange rate rule, in which exchange rate movements were linked to the inflation differential between Ghana and its major trading partners. Also a system of bonuses on foreign exchange receipts and surcharges on payments was introduced (April 1983).

- $\quad$ The system of bonuses and surcharges was abolished (October 1983)

- Authorized foreign exchange dealers permitted to open foreign accounts for residents and non-residents (June 1985)

- A dual exchange rate system with two windows was introduced, one of the windows being an auction. Bank of Ghana (BoG) sold foreign exchange to end users only (September 1986)

- $\quad$ Foreign exchange bureaus were established resulting in two spot foreign exchange markets (February 1988)

- A wholesale foreign exchange auction system was introduced and the retail one was discontinued (April 1990)

- Weekly wholesale foreign exchange auction coordinated by BoG was replaced by an interbank market (March 1992)

- Ghana accepted the obligations of Article VIII, Sections 2, 3, and 4, of the Funds Articles of Agreement (February 1994).

devalue the cedi and, faced with balance of payments problems, tended to resort to ad hoc restrictions on trade and exchange rate payments. The cedi parity was maintained until June 1978, when the cedi was devalued to $\mathbb{C} 2.75$ per US dollar, and then kept unchanged until April 1983, when it was again devalued in the context of the ERP.

80. From April 1983 to September 1986, the authorities adopted a real exchange rate rule with periodic adjustments in the cedi rate in accordance with the inflation differential between 
Ghana and its major trading partners (see Figure 5). ${ }^{28}$ During the seventies and most of the eighties, administrative controls still played an important role in the allocation of foreign exchange, giving rise to a very active parallel foreign exchange market. In 1982, the parallel market exchange rate reached as high as 2,100 percent of the official rate, but after the adoption of the real exchange rate rule it fell to twice the official exchange rate in early 1986. In September 1986, a dual exchange rate market was introduced, in which the exchange rate in one of the windows was determined by auction. ${ }^{29}$ In February 1987, the dual exchange rate system was eliminated, and all operations began to be conducted at the auction rate. In order to curb the parallel market for foreign exchange, foreign exchange bureaus were allowed to operate beginning February 1988. This initiative led to the absorption of the parallel market in the redefined legal structure. The result was, however, an exchange system with two spot foreign exchange markets: the bureau rate and the auction rate. This system remained in place until April 1990.

81. By April 1990, the spread between the bureau rate and the auction rate had narrowed to around 8 percent, and the Bank of Ghana was able to unify these two rates. It also introduced, at the same time, a system of weekly wholesale foreign exchange auctions, which remained in place until an interbank market in foreign exchange was set up in March 1992.

82. With foreign exchange being allocated by market mechanisms, the need for exchange restrictions gradually declined. From October 1986, the reforms of the exchange rate system were accompanied by the removal of import licencing, rationalization of import tariffs and the removal of all restrictions on payments and transfers for current international transactions. By February 1994, Ghana was able to accept the obligations of Article VIII, Sections 2, 3 and 4 of the IMF Articles of Agreement.

\section{Traditional Competitiveness Indicators}

83. A useful measure of competitiveness is the real exchange rate, whose movements are associated with changes in a country's balance of trade in goods and nonfactor services. The real exchange rate is usually constructed by deflating the nominal exchange rate, using price

\footnotetext{
${ }^{28}$ In April 1983, the government also introduced a system of bonuses for foreign exchange receipts and surcharges for payments. This cumbersome system was abolished in October 1983.

${ }^{29}$ Foreign exchange for debt service payments for debt contracted before January 1,1986 , petroleum imports, and essential drugs were provided at a pegged rate (C90 per US dollar) through the first window. All other transactions were conducted through the second window. Foreign exchange earnings from cocoa and residual oil products were surrendered at the first window exchange rate.
} 
Figure 5. Ghana: Exchange Rate, 1980-98

(In cedis per U.S. dollar, end-of-period)

$1980-89$

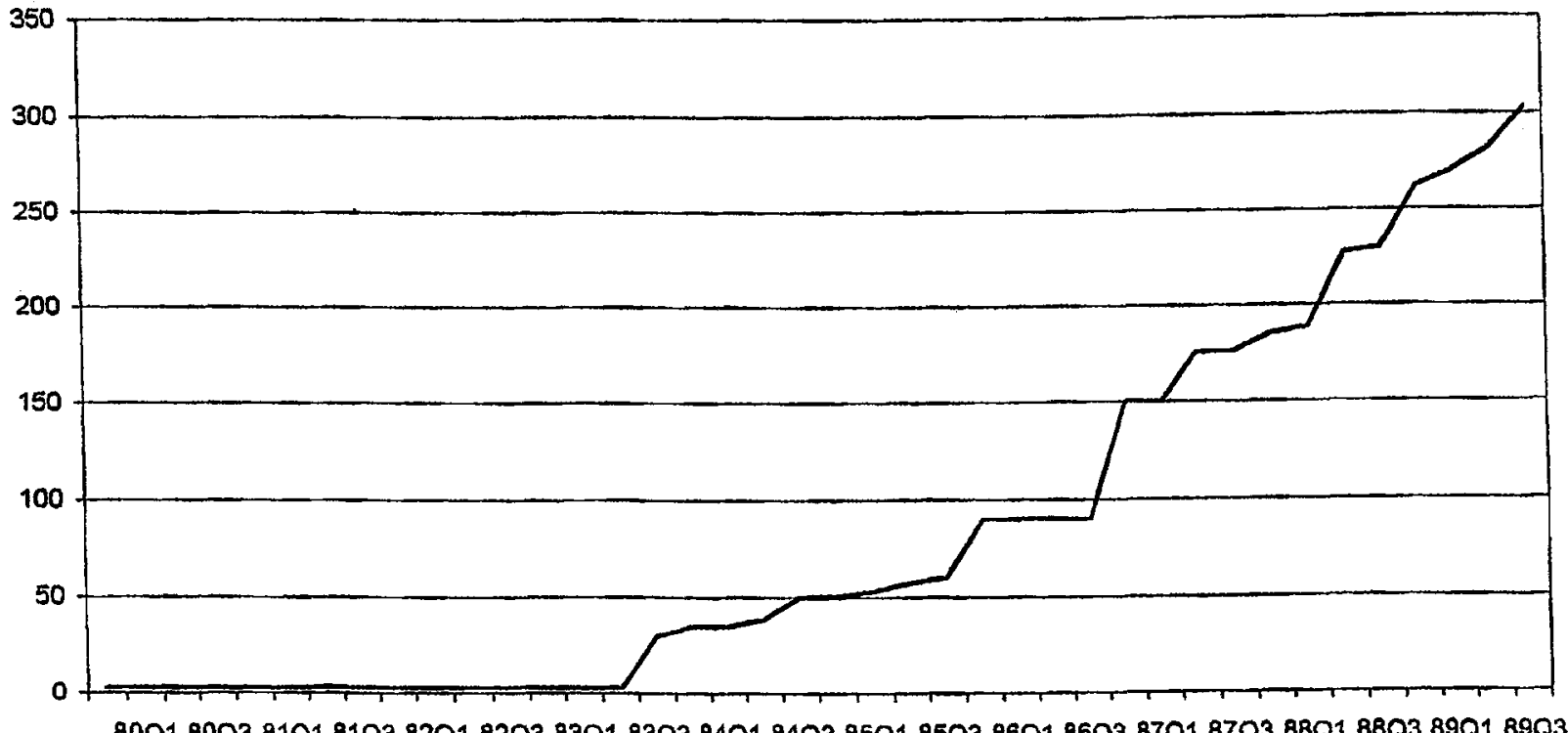

$80 Q 1$ B0Q3 81Q1 81Q3 82Q1 B2Q3 83Q1 83Q3 84Q1 84Q3 85Q1 85Q3 86Q1 86Q3 87Q1 87Q3 8BQ1 B8Q3 89Q1 B9Q3

$1990-98$

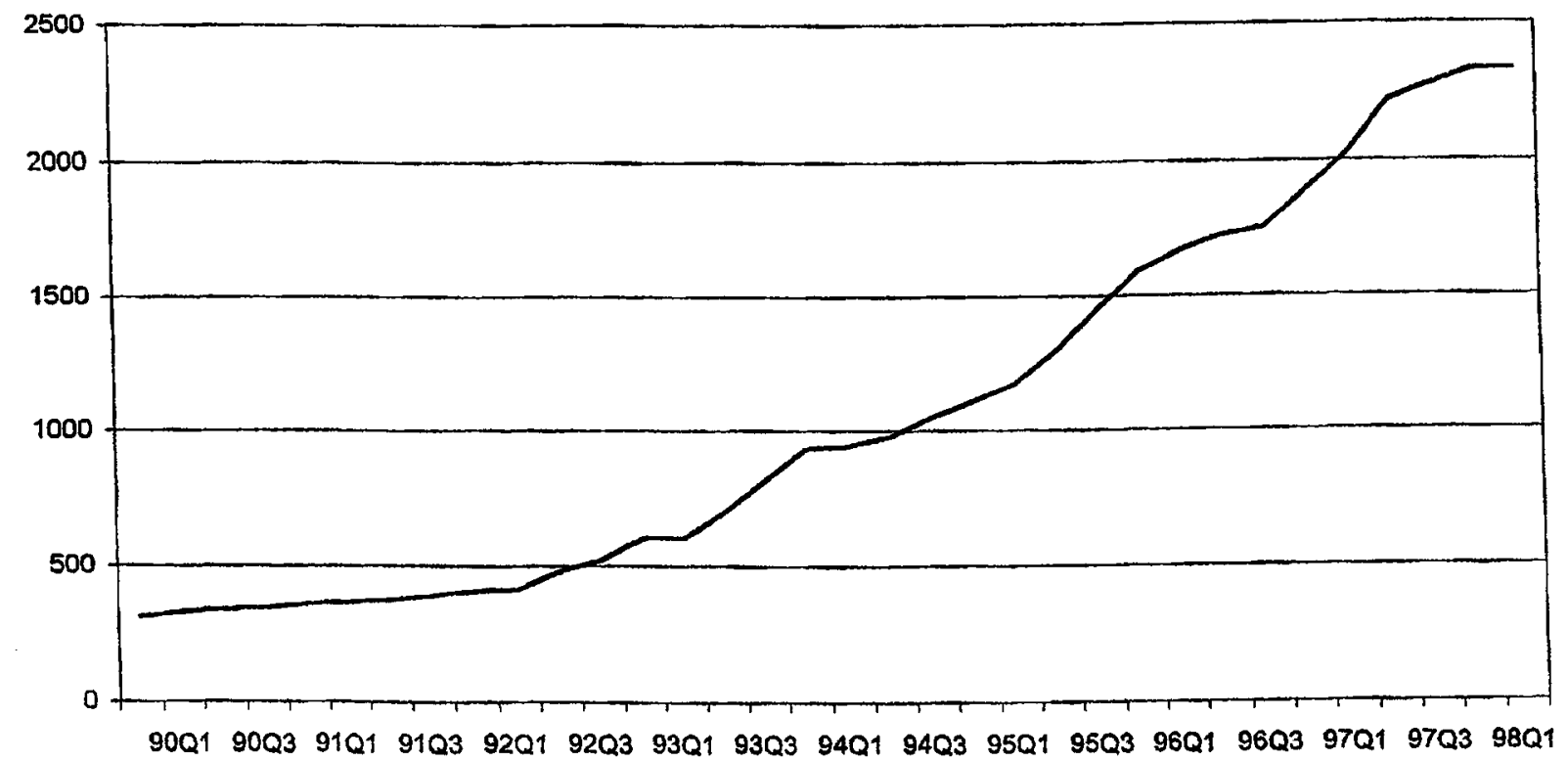

Sources: IMF, International Financial Statistics.

CInternational Monetary Fund. Not for Redistribution 
indices, such as the consumer price index (CPI), GDP deflator, export deflator, import deflator, or cost indices, like unit labor costs.

84. No single indicator provides an unambiguous assessment of competitiveness, with each indicator having pros and cons. Therefore, each indicator needs to be carefully considered. Regarding the price indices, CPI-based real exchange rates are easily available and cover a large range of products that are fairly comparable across countries (Turner and Van't dack (1993)). In addition, because wages are often influenced by CPI developments, CPIbased real exchange rates could be a good proxy for developments in a country's cost competitiveness. However, CPI-based real exchange rates also reflect taxes and other institutional distortions, include the prices of services, many of which are nontradable, and do not take directly into account the prices of many tradable goods, like intermediate goods. Real exchange rates based on GDP deflators incorporate the ratio of the relative prices of nontradable to tradable goods at home and abroad, and accordingly, movements in important determinants of trade flows; however, these data are less frequently available and less accurately constructed. Real exchange rates based on export and import deflators provide useful information on a country's export and import performance, respectively, and consequently on its trade balance. However, as each indicator does not contain information relevant for assessing both import and export performance, they may not incorporate all the information on competitiveness needed to explain movements in the trade balance (Marsh and Tokarick, 1994). Furthermore, these indicators cover country-specific range of products, that are often difficult to compare across countries.

85. Indicators based on unit labor costs provide information about underlying costs of production and are defined similarly across countries. However, they are essentially focused on the manufacturing sector and cannot detect changes in the costs of other components of production, such as capital and intermediate inputs, and they are subject to large measurement errors (Lipschitz and McDonald (1991)).

\section{Competitiveness Indicators for Ghana}

86. In this section, Ghana's competitiveness is assessed using indicators based on prices and unit labor costs. In particular, real effective exchange rates are calculated considering the consumer price index, GDP, export, and import deflators, and unit labor costs. The choice of competitiveness indicators is limited by the availability and accuracy of data. The results are analyzed taking into consideration these limitations, as well as advantages and disadvantages of each indicator.

\section{Price-based indicators using CPI, GDP, export, and import deflators}

87. Ghana's CPI-based real effective exchange rate (REER) vis-à-vis its major trading partners (United Kingdom, Germany, United States, Japan, France, Netherlands, Italy, Canada, Belgium, Brazil, Korea, Australia, Switzerland, China, Spain, Sweden, the Taiwan 
Province of China, Malaysia, Austria, and India) ${ }^{30}$ was calculated for the period 1980-97 (Figure 6, top panel). The figure shows an appreciation of the REER of 180 percent over the period 1980-82, clearly indicating a deterioration of Ghana's competitiveness. However, in 1983 this tendency started to reverse, and Ghana's REER depreciated by 93 percent by 1987 in comparison with its peak in 1982. The gain in competitiveness continued, although at a lower pace, through 1994. The last three years, 1995-97, are instead characterized by a slight deterioration of Ghana's competitiveness, as shown by the CPI-based REER that in 1997 had already appreciated 35 percent with respect to its 1994 level (Figure 7, top panel).

88. Ghana's competitiveness as indicated by the CPI-based REER reflects the nominal appreciation of the cedi over the period 1980-82, followed by a series of devaluations, in particular, during the first stage of the reform of the exchange rate system that started in 1983. As seen above, the cedi was devalued in stages from $\mathbb{C} 2.75$ per U.S. dollar in April 1983, to C90 per U.S. dollar by January 1986 , which meant a devaluation of 3,172 percent in less than three years. As the reform of trade and the exchange rate continued through 1994, the cedi continued to depreciate, reaching a value of $\mathbb{C 1} 1,052$ per U.S. dollar at the end of 1994 . In 1995, the CPI-based REER started to appreciate, reflecting a surge in inflation from 35 percent at the end of 1994 to 70 percent in 1995 . The appreciation of the CPI-based REER continued in 1996-97, although at a lower pace.

89. The real effective exchange rate based on the GDP deflator presents a picture very similar to the one given by the CPI-based REER (Figure 6, bottom panel). From 1980 to 1982, Ghana's competitiveness deteriorated markedly, as indicated by the appreciation of 139 percent of the GDP-deflator-based REER. However, it improved noticeably after 1983, as the GDP-deflator-based REER depreciated by 75 percent and 91 percent in 1984 and 1987, respectively, with respect to its 1982 level. The gain in competitiveness continued until 1994, although at a lower pace. Afterward, the GDP-deflator-based REER shows a slight appreciation over the period 1995-97 (Figure 7, bottom panel).

90. The real effective exchange rate based on the export deflator (Figures 8 and 9, bottom panel) shows an overall gain in competitiveness over the entire period under consideration. Unlike the other two indicators, the export-deflator-based REER indicates a gain in competitiveness over the period 1995-97. This gain could be attributed to the fact that the export price grew less than consumer and GDP indices, which in turn could be explained by the fact that Ghana exports mainly commodities such as cocoa and gold, whose prices are determined in the world market. If the depreciation of the REER based on export deflator was mainly related to the fact that Ghana is a price taker, an assessment on competitiveness based on such an indicator could be misleading.

\footnotetext{
${ }^{30}$ The trading patterns and their relative weights for the calculation of the REER are those used by the IMF's Information Notice System.
} 
Figure 6. Ghana: Real Effective Exchange Rate, 1980-97

(Index, 1980=100)

Based on CPI
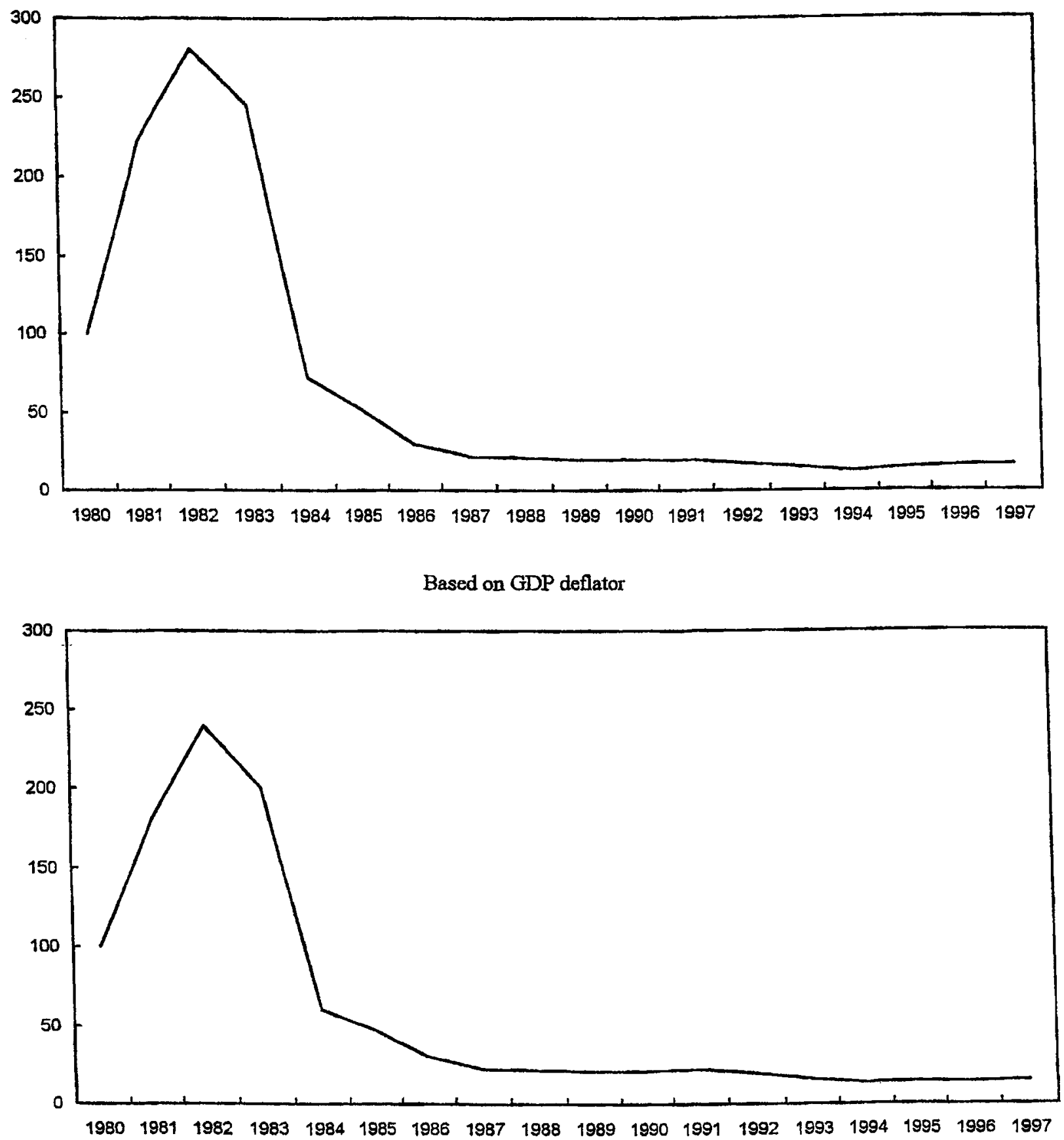

Sources: IMF, Information Notice System and WEO. 
Figure 7. Ghana: Real Effective Exchange Rate, 1990-97

(Index, 1990=100)

Based on CPI

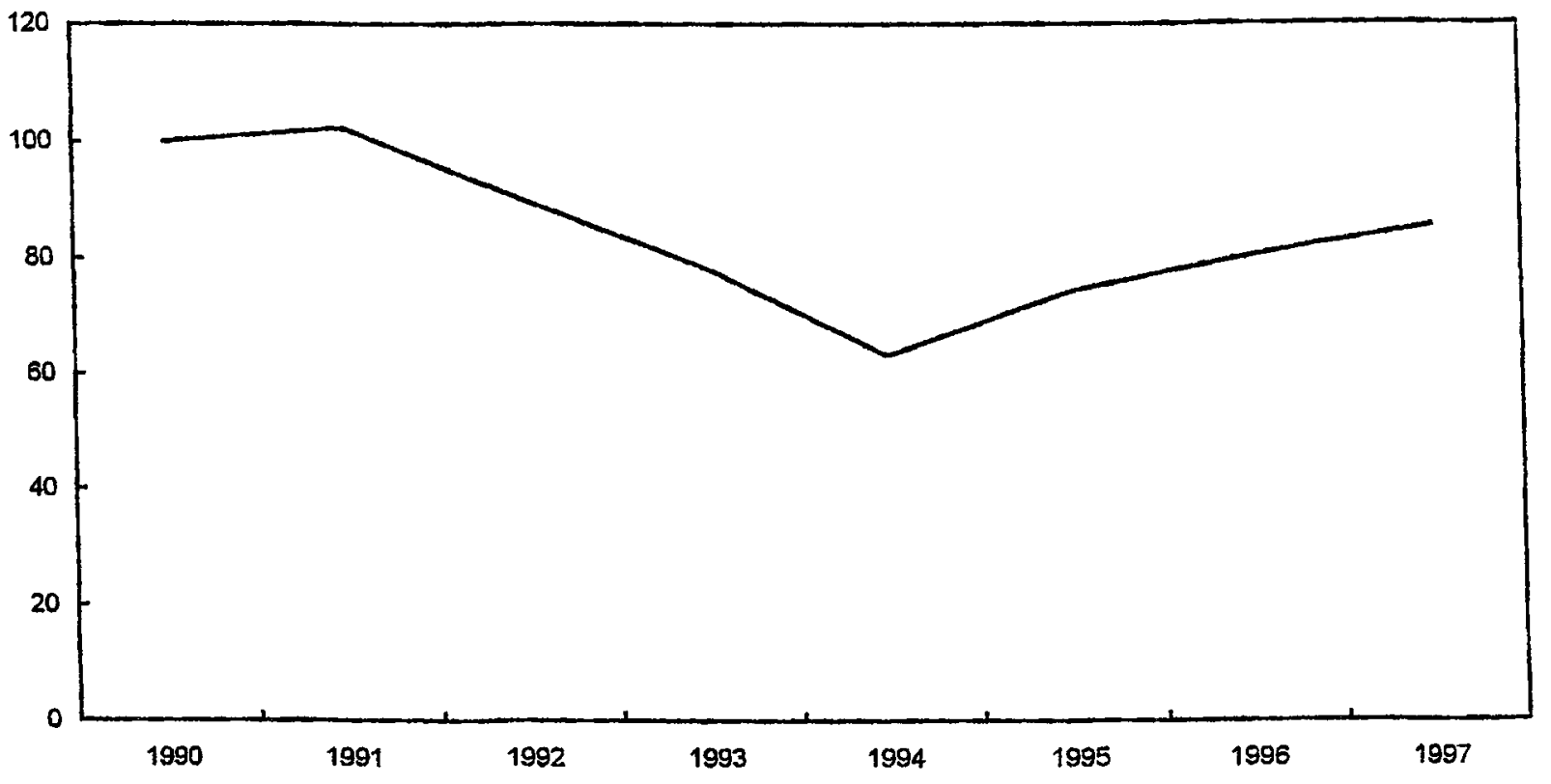

Based on GDP Deflator

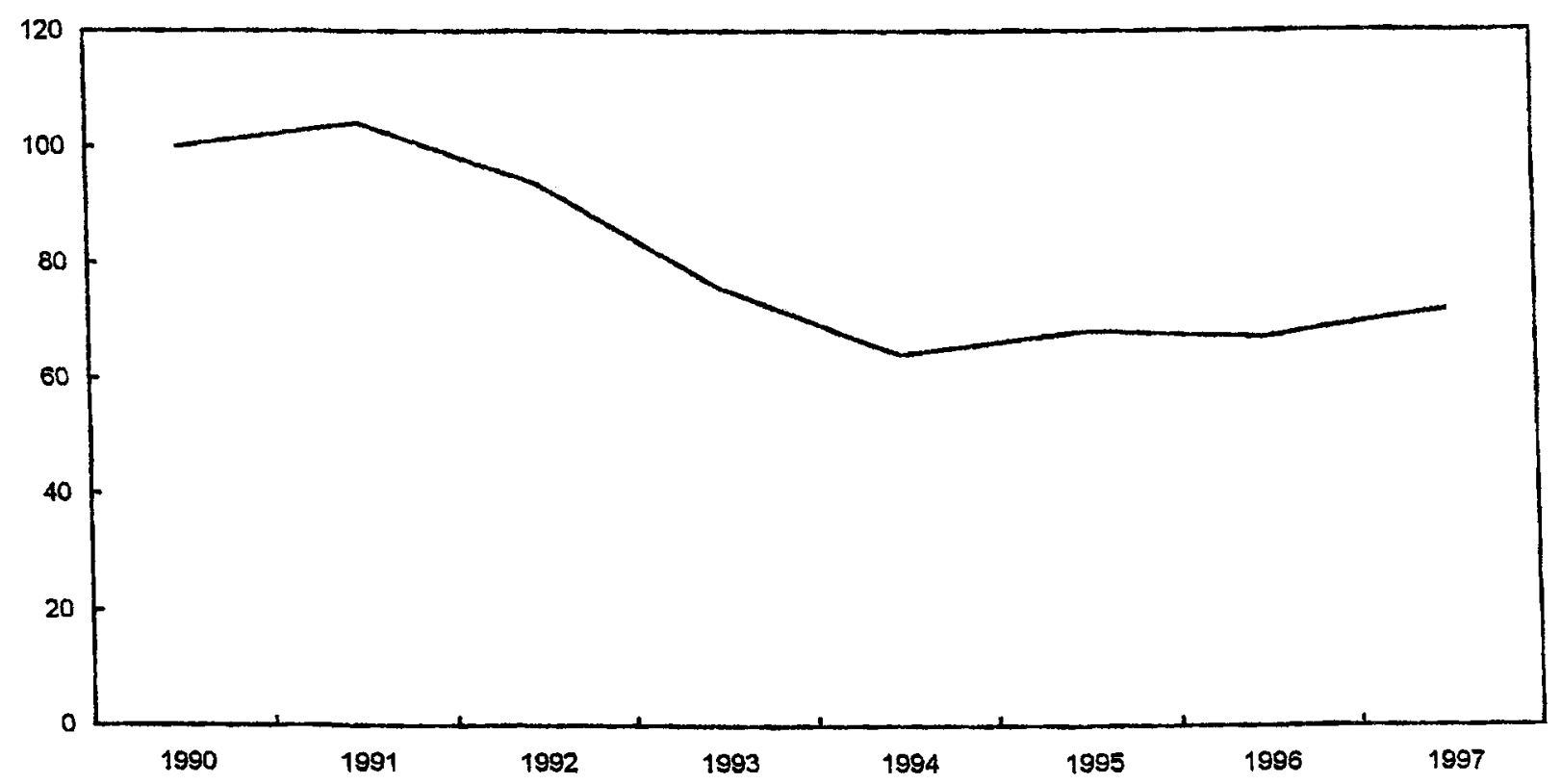

Sources: IMF, Information Notice System and WEO. 
91. Like the previous indicator, the real effective exchange rate based on import deflator (Figures 8 and 9, top panel) shows an overall gain in competitiveness over the period 19831997. This gain could reflect that the growth of import prices was slower than the growth of the prices of local products that are part of the basket of the CPI products. In 1997, this difference could be attributed to the sharp reduction in petroleum prices. However, to the extend that similar declines were observed by Ghana's competitors in international markets, it is not clear that the external competitiveness of Ghana was affected in a significant manner.

\section{Unit-Labor-Cost-Based Indicators}

92. The real effective exchange rate based on unit labor cost indices (ULCI) ${ }^{31}$ was calculated for the period 1981-97 (Figure 10) ${ }^{32}$ This indicator suggests that there was a strong deterioration of Ghana's competitiveness from 1981 to 1982 , followed by a remarkable gain thereafter. The ULCI-based REER appreciated by 49 percent from 1981 to 1982, and in the following five years it depreciated by 77 percent with respect to its 1982 level. After a slight appreciation in 1989, the ULCI-based REER continued to depreciate, reaching its lowest point in 1991. In 1992, Ghana's ULCI-based REER appreciated by 41 percent with respect to its 1991 level, and in the following two years it regained approximately the level reached in 1991. During the last two years under study, 1996-97, the ULCI-based REER shows a slight appreciation, suggesting that Ghana's competitiveness has recently shown a tendency to deteriorate.

93. Over the period 1981-90, the pattern of Ghana's competitiveness suggested by the ULCI-based REER was mainly driven by the behavior of the cedi before and during the ERP. In 1992, the ULCI-based REER appreciated remarkably, as a wage increase of 80 percent was granted to public employees. In the following years, Ghana's government made efforts to contain wage increases. These efforts are reflected in the slight gain in Ghana's competitiveness in 1993-94. However, despite the wage containment, over the last three years, 1995-97, the indicator suggests a slight tendency for Ghana's competitiveness to weaken.

${ }^{31}$ The ULCI is defined as the ratio of the index of monthly compensation per worker to the index of monthly production per worker in the manufacturing sector. The calculation of the ULCI for Ghana for the period 1992-97 is based on the assumption that the growth rate of the monthly compensation per worker and the number of workers in the manufacturing sector are equal to the growth rates of the average monthly salary of contributors to Ghana's social security system and the number of contributors to the system in the manufacturing sector, respectively.

${ }^{32}$ The trading partners for the calculation of the ULCI-based REER are those used by the IMF"s Information Notice System, excluding Brazil, China, Malaysia, and India. The selection of the trading partners was limited by the availability of data. 
Figure 8. Ghana: Real Effective Exchange Rate, 1980-97

(Index, 1980=100)

Based on Import Deflator
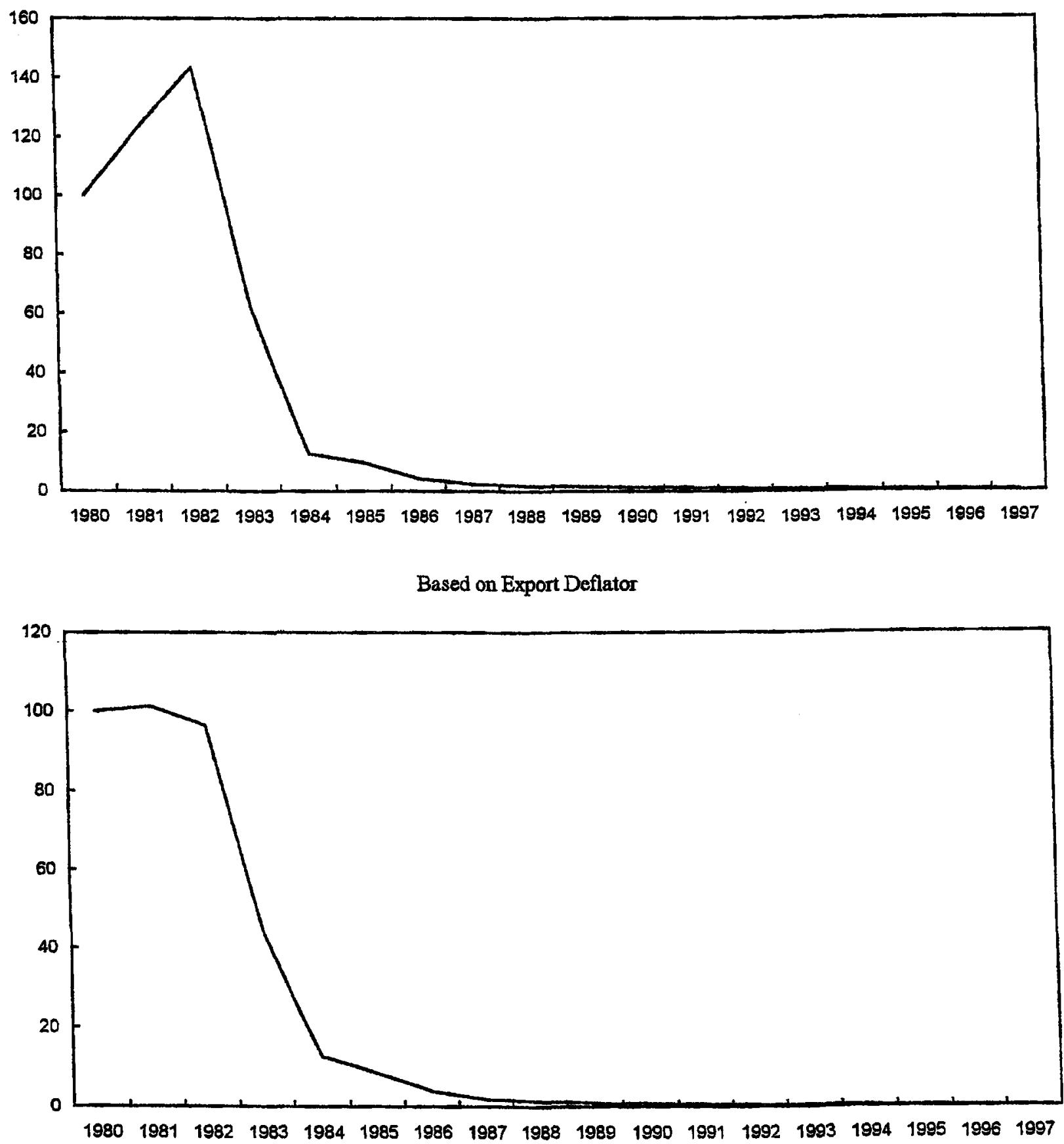

Sources: IMF, Information Notice System and WEO. 
Figure 9. Ghana: Real Effective Exchange Rate, 1990-97

(Index, 1990=100)

Based on Import Deflator

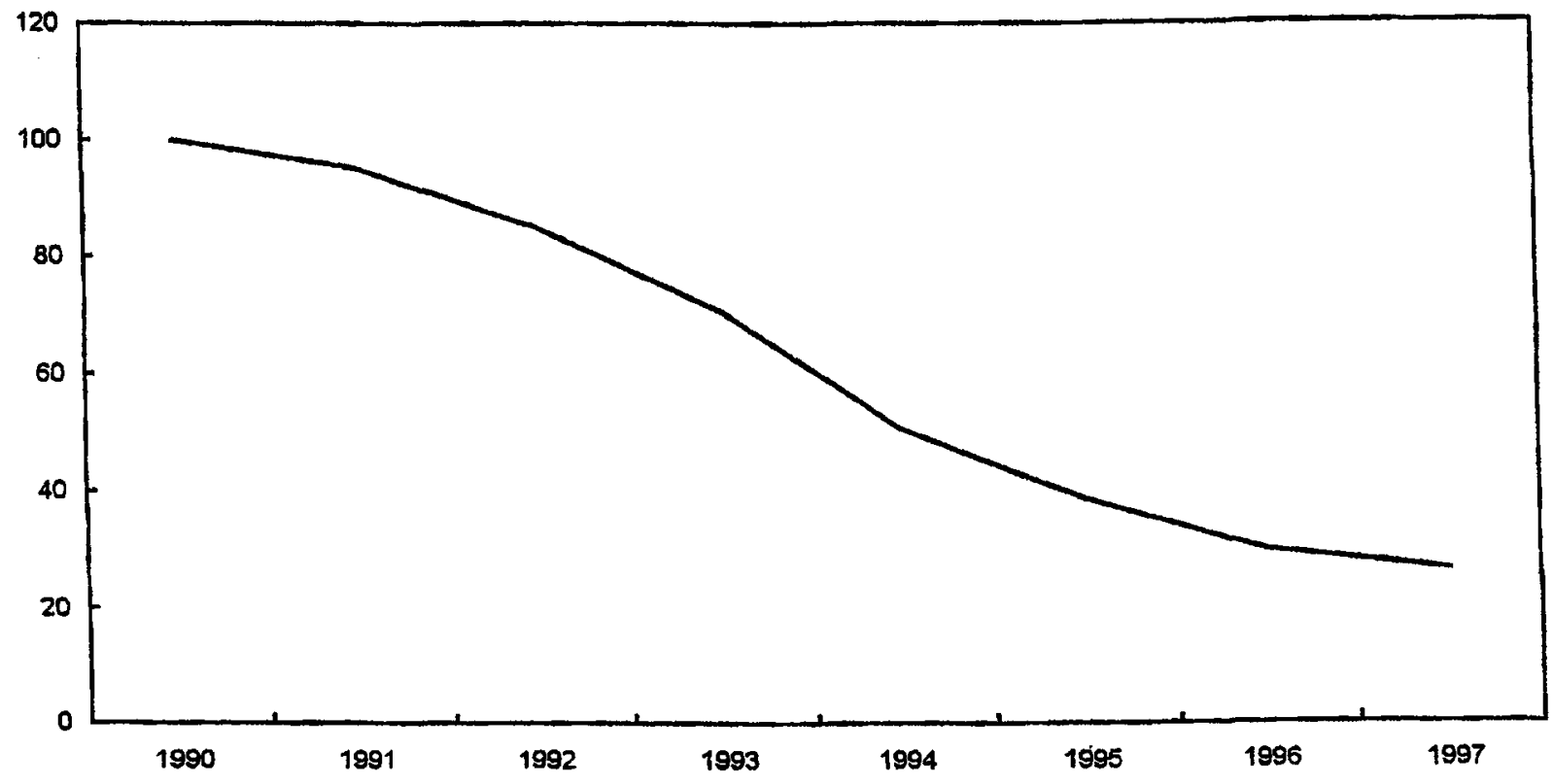

Based on Export Deflator

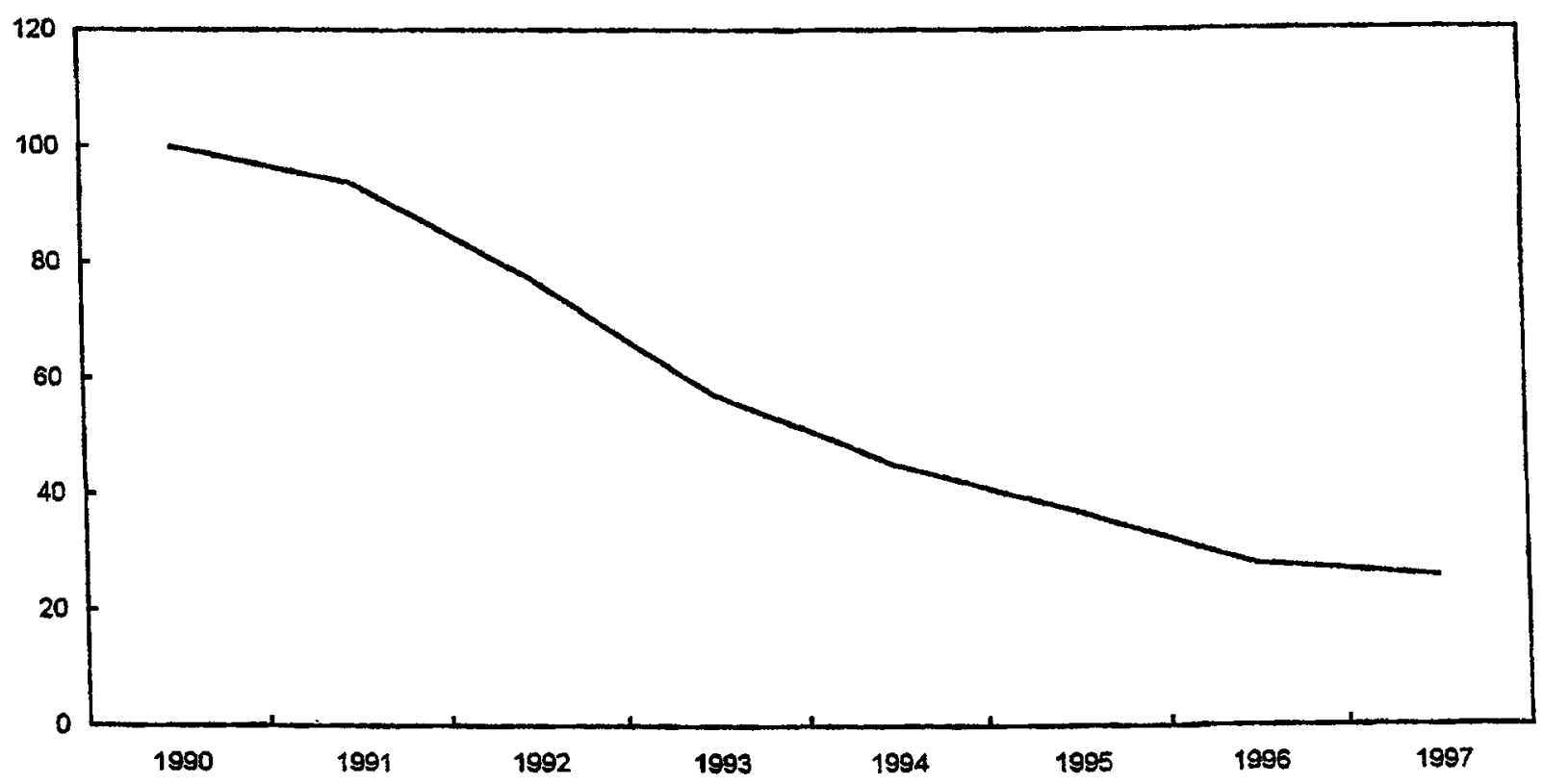

Sources: IMF, Information Notice System and WEO. 
Figure 10. Ghana: Real Effective Exchange Rate Based on Unit Labor Cost Index, 1981-97 $(1981=100)$

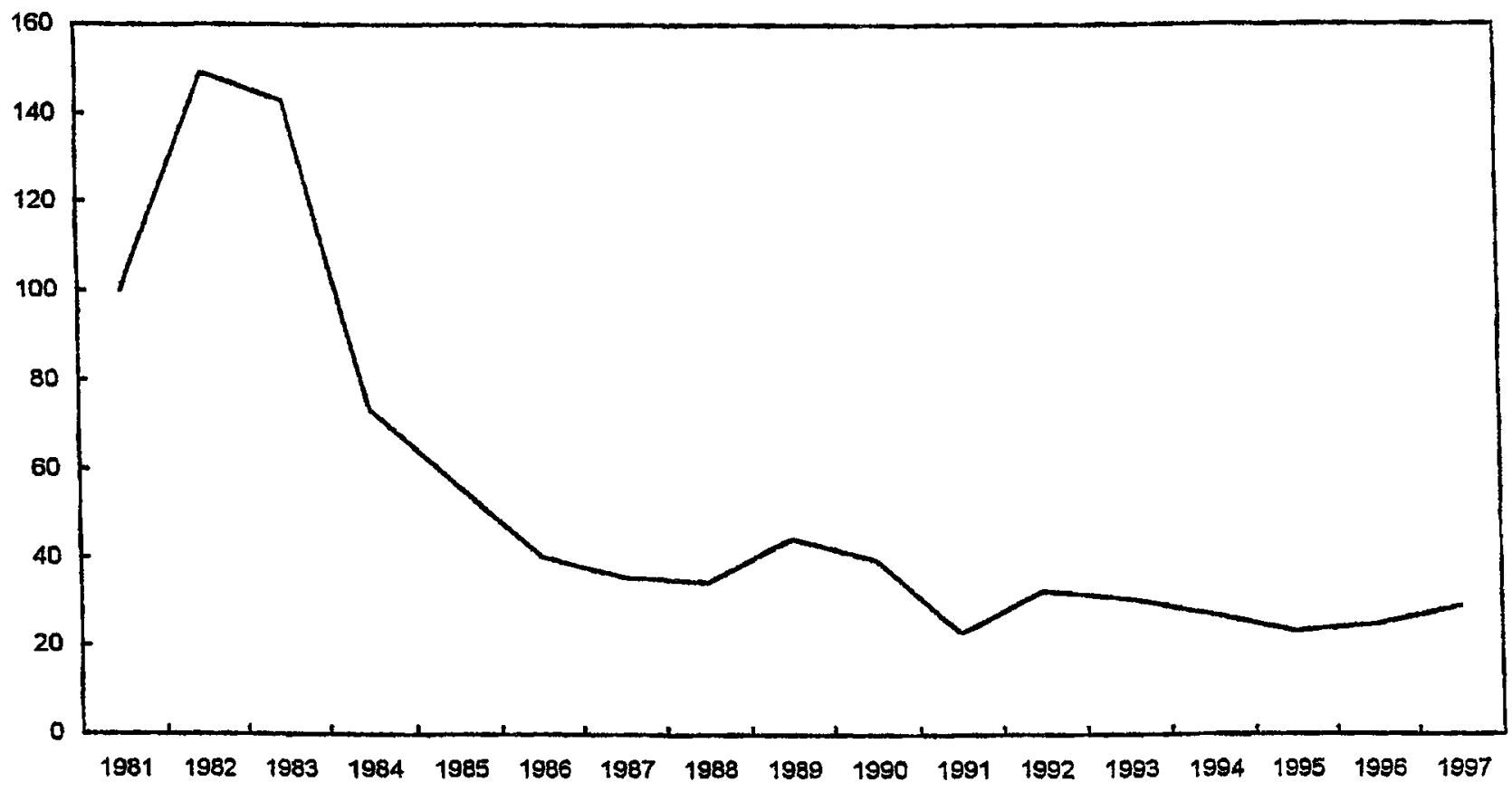

Sources: IMF, Information Notice System; SSNT; and staff estimates. 


\section{A comparison with some neighboring countries}

94. Ghana's competitiveness was compared with that of its neighboring countries, Burkina Faso, Côte d'Ivoire, Nigeria, and Togo, from the first quarter of 1980 to the second quarter of 1998. The comparison is built on the CPI-based REER, calculated considering three different groups of trading partners. The first group comprises all major trading partners of the country; the second one consists of the major trading partner; ${ }^{33}$ and the third one comprises all major trading partners, excluding the major partner. The analysis covers two periods, from the first quarter of 1980 to the second quarter of 1990 , and from the third quarter of 1990 to the second quarter of 1998 . The two periods highlight the performance of Ghana's competitiveness with respect to its neighboring countries before and after Ghana concluded its exchange system reform, which occurred in the second quarter of 1990.

95. Ghana's competitiveness vis-à-vis its major trading partners deteriorated markedly from the first quarter of 1980 to the first quarter of 1983, while the competitiveness of its neighboring countries remained relatively stable, with the exception of Nigeria. This tendency was reversed between the second quarter of 1983 (Figure 11, top panel) and the second quarter of 1985, when Ghana began to gain competitiveness with respect to all other countries, a trend that continued until the second quarter of 1990.

96. After the conclusion of the exchange system reform in 1990 , Ghana continued to gain in competitiveness with respect to all other countries, except Nigeria, until the first quarter of 1994, when the CFA devalued (Figure 12, top panel). Afterwards, Ghana's competitiveness followed a behavior close to that of the CFA countries considered in the study (Burkina Faso, Côte d'Ivoire, and Togo), while Nigeria's competitiveness deteriorated markedly. From the third quarter of 1990 to the second quarter of 1998, Ghana's real effective exchange rate followed closely the pattern of the real effective exchange rate of the CFA countries, although after the devaluation of the CFA it appreciated slightly faster.

97. Ghana's competitiveness against its major partner country, the United Kingdom, shows a similar pattern, over the period 1980-89 (Figure 11, middle panel). Overall, from the third quarter of 1990 to the second quarter of 1998, Ghana's competitiveness remained broadly unchanged, after a slight improvement through the first quarter of 1994, followed by a slight deterioration that continued until the first half of 1998 (Figure 12, middle panel). In the third quarter of 1992, Ghana's competitiveness experienced a slump, as the pound sterling devaluated and exited from the European Monetary System. Over the period under consideration, Ghana's bilateral real effective exchange rate roughly followed the bilateral real effective exchange rates of the CFA countries, Burkina Faso, Côte d'Ivoire, and Togo.

${ }^{33}$ The major trading partner of Ghana, is the United Kingdom, which accounts for almost a 17 percent weight in the effective exchange rate. The major trading partner of Burkina Faso, Côte d'Ivoire, and Togo is France; for Nigeria is the United Kingdom. 
Figure 11. Ghana: Competitiveness with Neighboring Countries, 1980Q1-1990Q2

$$
\text { (Index, 1980Q1=100) }
$$

\section{Competetitiveness vis-à-vis All Major Trading Partners}

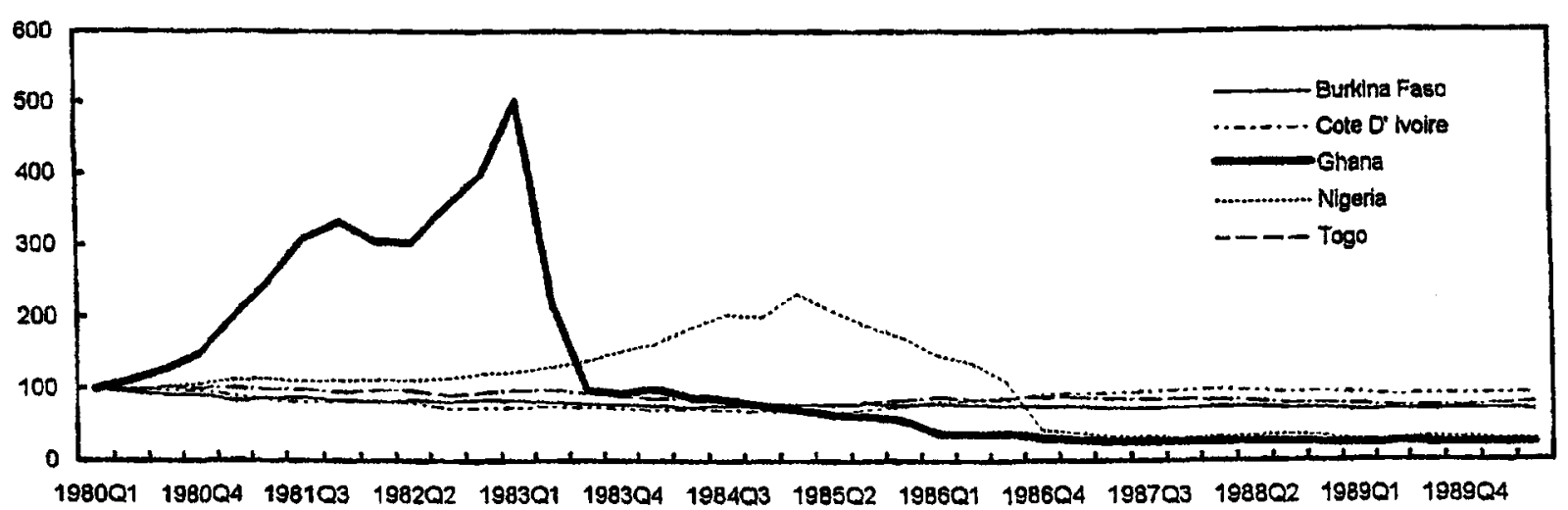

Competitiveness vis-à-vis the Major Trading Partner

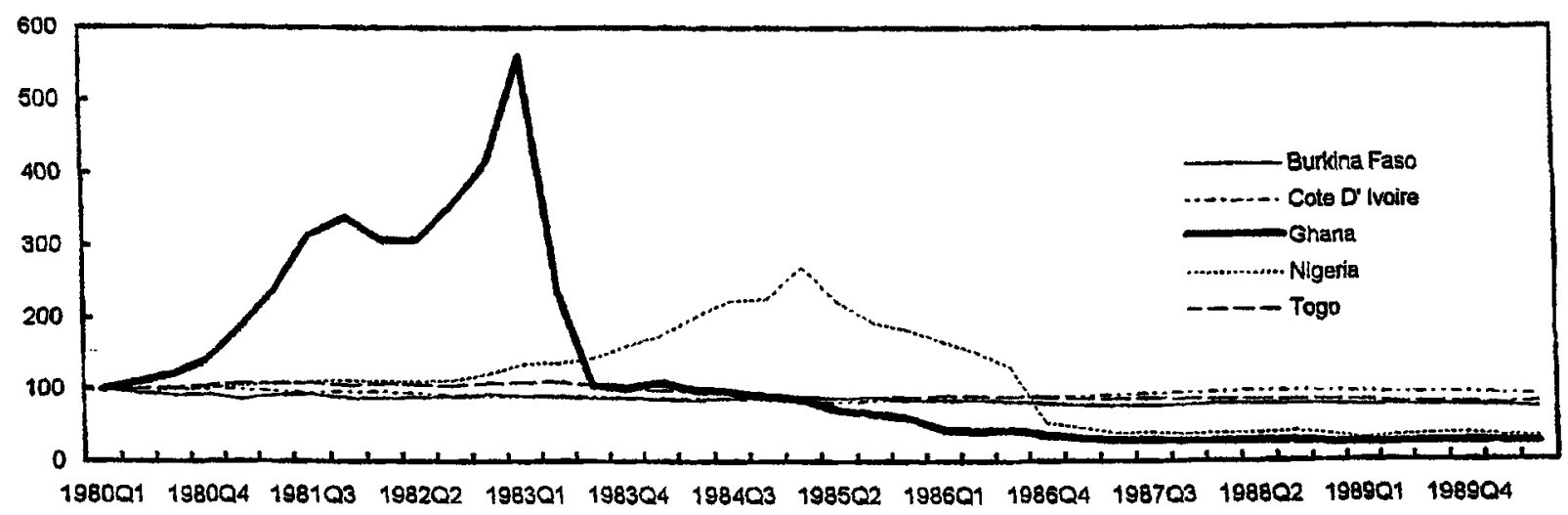

Competitiveness vis-à-vis All Major Trading Partners, Excluding the Major Partner

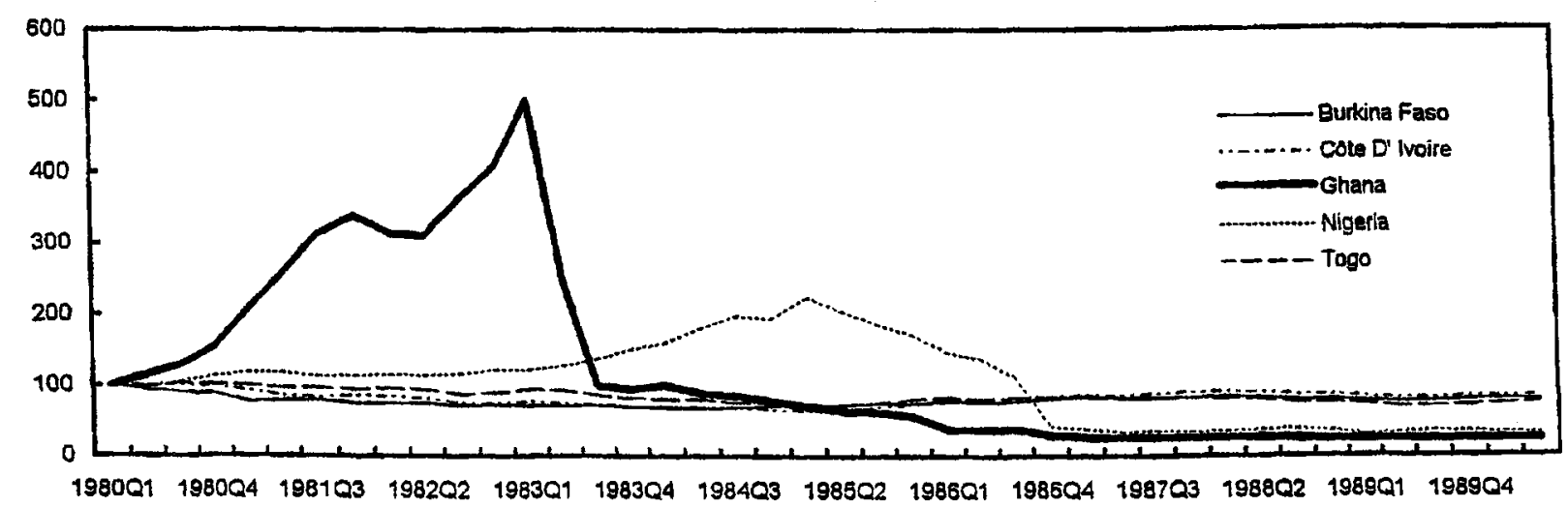

Source: IMF, Information Notice System. 
Figure 12. Ghana: Competitiveness with Neighboring Countries, 1990Q3-1998Q2

(Index, 1990Q3=100)

Competitiveness vis-à-vis All Major Trading Partners

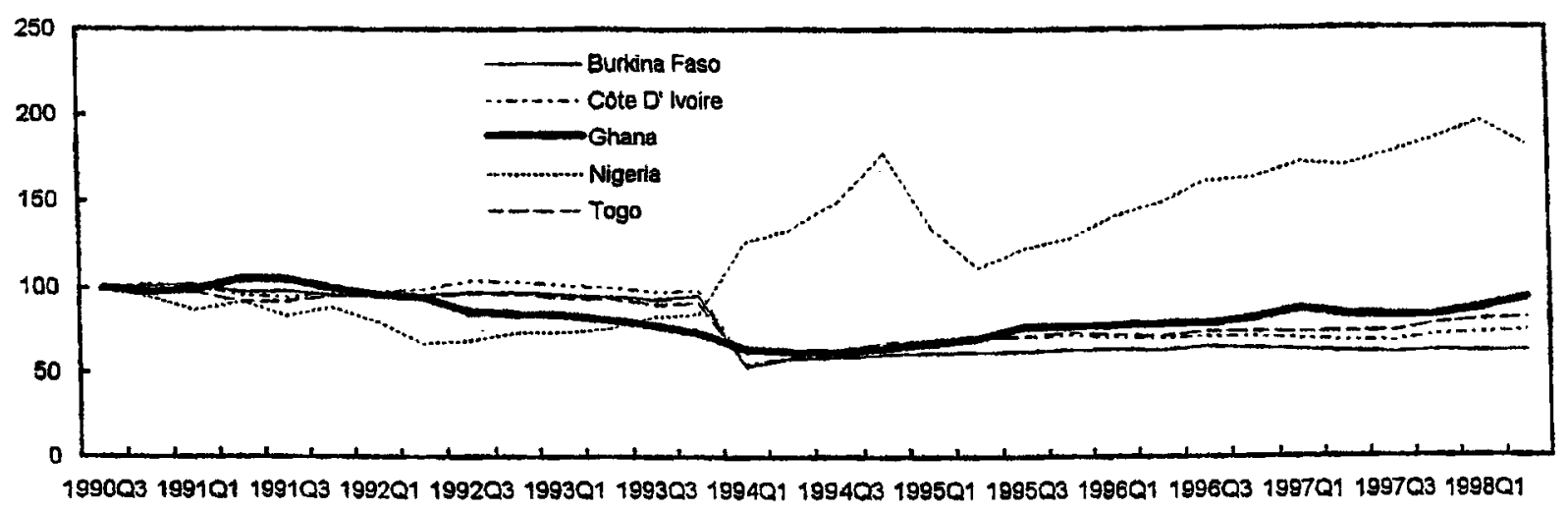

\section{Competitiveness vis-à-vis the Major Trading Partner}
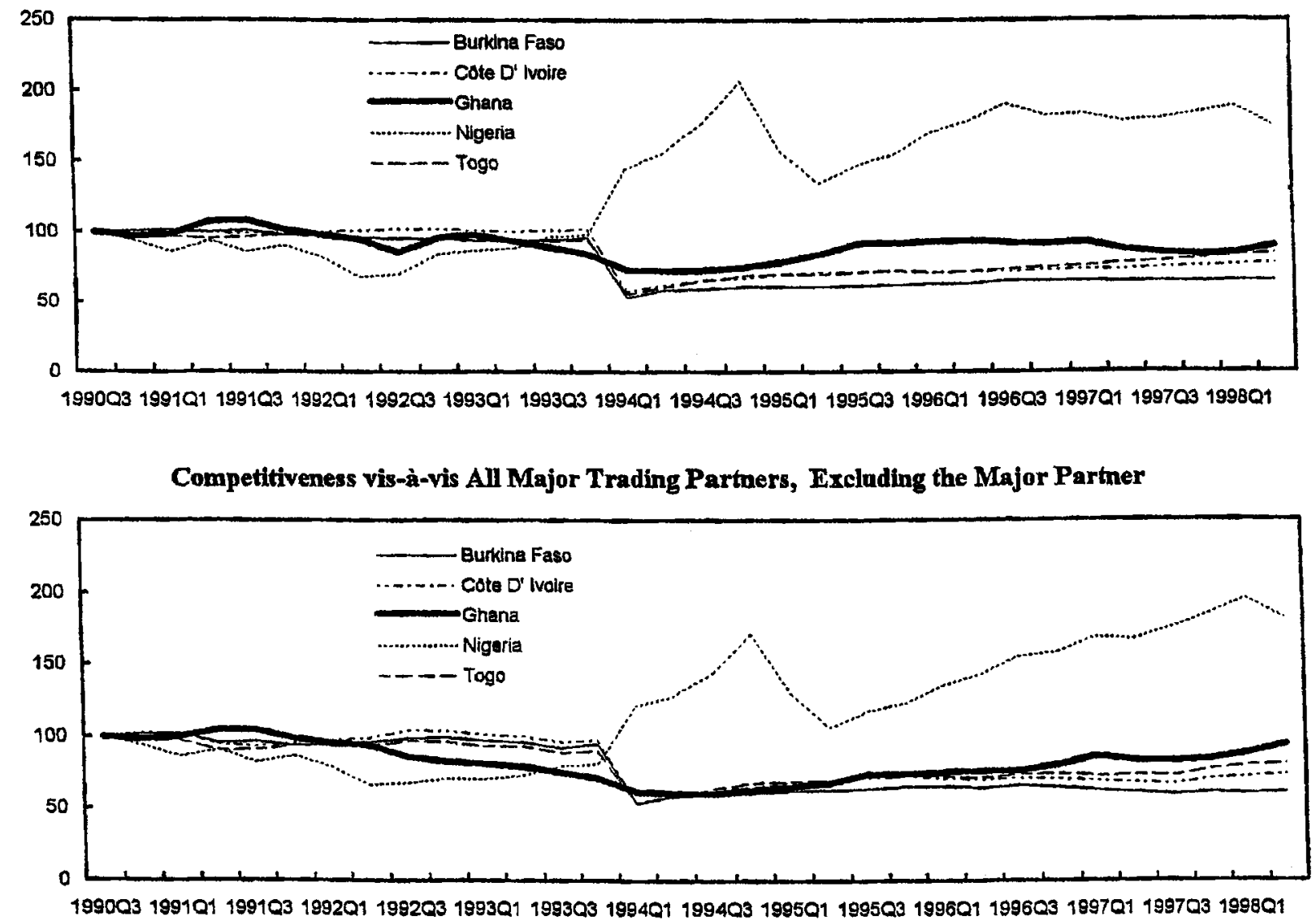

Source: IMF, Information Notice System. 
98. Ghana's competitiveness against its other major trading partners, mostly the European Union, the United States, and Japan, also showed a deterioration from 1980 to the end of 1983, followed by a markedly gain through the beginning of 1990 (Figure 11, bottom panel). From the third quarter of 1990 to the second quarter of 1998, Ghana's competitiveness followed smoothly the behavior of the CFA countries under consideration (Figure 12, bottom panel). Overall, Ghana's competitiveness remained quite stable from 1990 to the first half of 1998, with its level in the second quarter of 1998 very close to its 1990 level. However, while from 1990 to the first half of 1994, Ghana's competitiveness showed a tendency to improve, from the second half of 1994 to the first half of 1998, there seems to have been a slight but continuous deterioration of Ghana's competitiveness.

\section{E. Conclusions}

99. On the basis of a set of price (consumer, GDP, export, and import price indices) and unit labor cost indicators, Ghana's competitiveness deteriorated sharply from 1980 to 1982 , followed by an improvement through 1994. The evidence for the three year 1995-97 is mixed. The REERs based on the CPI and the GDP deflator, and on unit labor costs indicate an appreciation, while the REER based on export and import deflators shows a depreciation. Different factors, as reflected by the different indicators, can account for this mixed evidence, including the fact the Ghana's import and export deflators declined faster than the GDP deflator, the CPI, and ULCI. This faster decline, in the case of the export deflator, mainly reflects the fact that Ghana, whose main exports are commodities like cocoa and gold, is a price taker. In that case, the REER based on the export deflator could lead to misleading results. Compared with its neighboring countries, Ghana's competitiveness shows a similar, although smoother, pattern as the CFA countries Burkina Faso, Côte d'Ivoire, and Togo from the third quarter of 1990 to the second quarter of 1998, although after the devaluation of the CFA its tendency to appreciate was slightly steeper. Overall, Ghana's competitiveness remained quite stable from 1990 to the first half of 1998 , with its level in the second quarter of 1998 very close to its 1990 level. However, while from 1990 to the first half of 1994 , Ghana's competitiveness improved, from the second half of 1994 to the first half of 1998 most indicators point to a deterioration. 


\section{References}

Kapur, Ishan, and others, 1991, "Ghana: Adjustment and Growth, 1983-91," IMF Occasional Paper, No 86 (Washington: International Monetary Fund), September.

Lipschitz, Leslie, and Donogh McDonald, 1991,"Real Exchange Rates and Competitiveness: A Clarification of Concepts, and Some Measurements for Europe," IMF Working Paper 91/25, (Washington: International Monetary Fund).

Marsh, Ian W, and Stephen P. Tokarick, 1994, "Competitiveness Indicators: A Theoretical and Empirical Assessment," MMF Working Paper 94/29, (Washington: International Monetary Fund).

Turner, Phillip, and Jozef Van't dack, 1993, "Measuring International Price and Cost Competitiveness", BIS Economic Papers, No. 39, (Basle, Switzerland: Bank for International Settlements).

Wickham, Peter, 1993, “A Cautionary Note on the Use of Exchange Rate Indicators", IMF Paper on Policy Analysis and Assessment 93/5, (Washington: International Monetary Fund). 


\section{Trends in COCOA World Markets and Options to STRENGTHEN GHANA's COMPETITIVE POSTIION ${ }^{34}$}

\section{A. Introduction}

100. In the $1964 / 65$ crop season, Ghana's cocoa production reached its peak at 581,000 metric tons. At that time, Ghana was the largest world producer of cocoa accounting for 38 percent of world production. Since then, Ghana's cocoa production plummeted, bottoming in 1983/84 when production was only 160,000 metric tons and market share was 10 percent. From 1983/84 onwards, Ghana's production began to recover, although in 1997/98 it was still two-thirds of its 1964/65 peak. This chapter summarizes world cocoa trends in the last decade, as well as the reforms being implemented by Ghana to modernize its cocoa sector and avoid a further erosion of its market share. The chapter focuses in particular on the similarities and differences with Côte d'Ivoire, Ghana's neighbor and the largest world producer of cocoa. The paper concludes with a discussion of next steps and options, which the Ghana authorities will need to consider to ensure the long-run success of its cocoa industry.

\section{B. Cocoa Trends in the Last Decade ${ }^{35}$}

101. During the 1987-97 decade, world cocoa production had a generally upward trend increasing on average by about 4 percent a year (Figure 13). Ghana's production followed closely world trends, and therefore Ghana's share of world production remained unchanged at 13 percent. The same is not true, however, of Ghana's main competitors. Côte d'Ivoire, the world largest cocoa producer, saw its share of world production increase steadily from 21 percent in 1987 to 38 percent in 1997 (Figure 14 and Table 15). Indonesia, the fastest growing cocoa producer during the decade, expanded its production at an average annual rate of 21 percent, increasing its share of production from 2 percent in 1987 to 11 percent in 1997.

102. The rapid increase in the market shares of Côte d'Ivoire and Indonesia during 1987-97 is remarkable because international price developments were not particulariy favorable during the period. World cocoa prices tend to have ten-year cycles with recent troughs taking place in the second year of each decade. Therefore, the first half of the 1987-97 decade was one of declining prices, while the second half benefited from increasing prices (Figure 15). In spite of the upward price trends since 1992 , by 1997 world cocoa prices were still 15-19 percent below their levels in 1987. Clearly, factors other than world prices were playing an important role in sustaining the rapid expansion of the cocoa production in Côte d'Ivoire and Indonesia, while maintaining Ghana's growth barely in line with world production.

\footnotetext{
${ }^{34}$ Prepared by Tatsuya Kanai, Anthony Pellechio, and Sérgio Pereira Leite.

${ }^{35}$ For an overview of world trends in consumption, commercial production, and marketing, see Amoah (1996).
} 
Figure 13. World Cocoa Trends , 1987-97
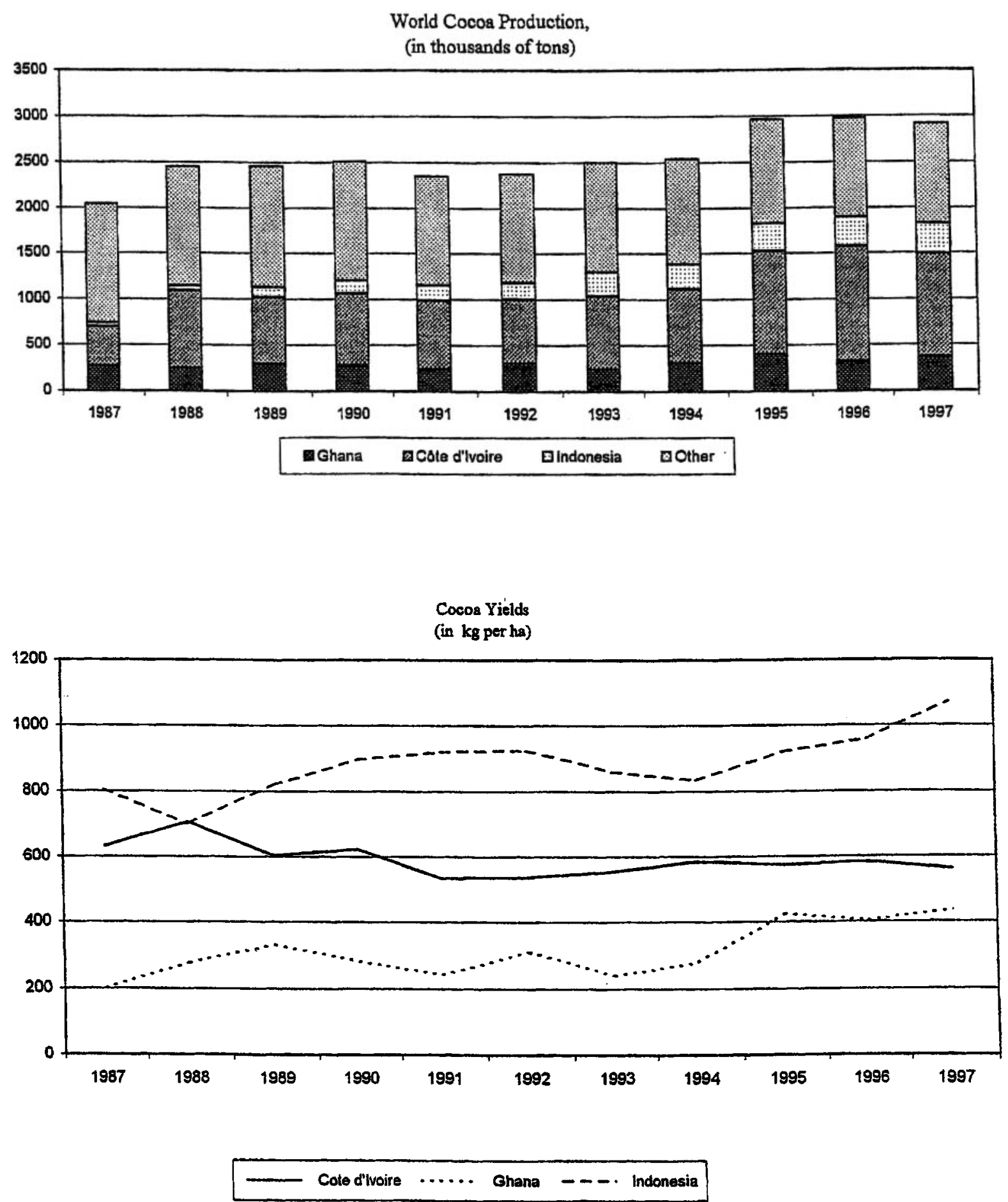

Source: FAO Yearbook.

CInternational Monetary Fund. Not for Redistribution 
Figure 14: Share of World Cocoa Production

1987

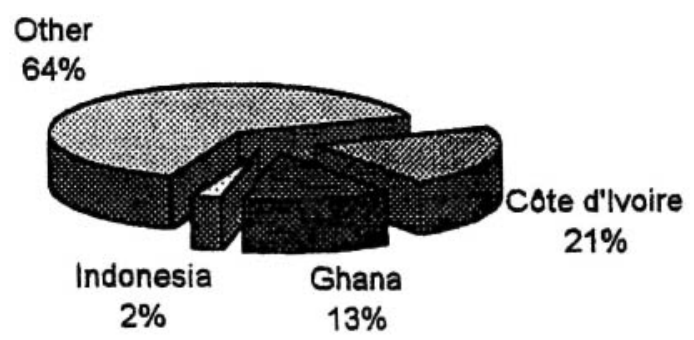

1992

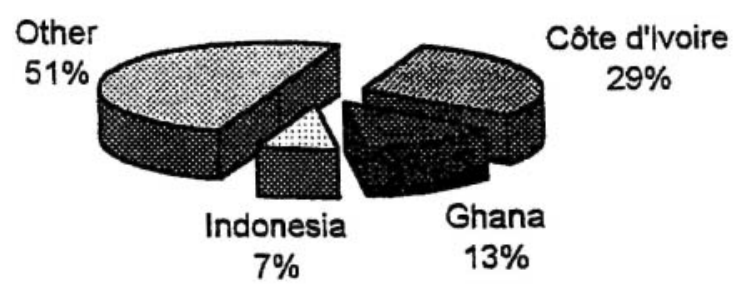

1997

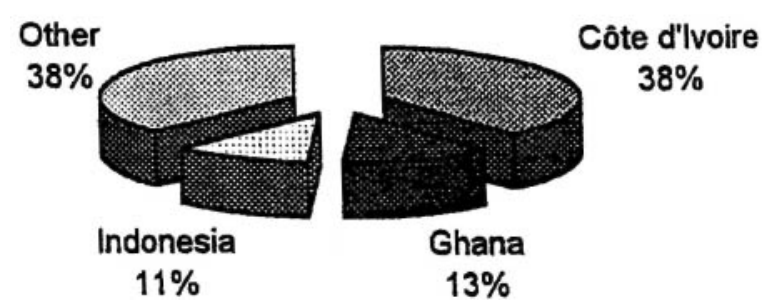

Source: FAO Yearbook

CInternational Monetary Fund. Not for Redistribution 
Figure 15. World Cocoa Prices, 1987-97

(In U.S. cents per pound )

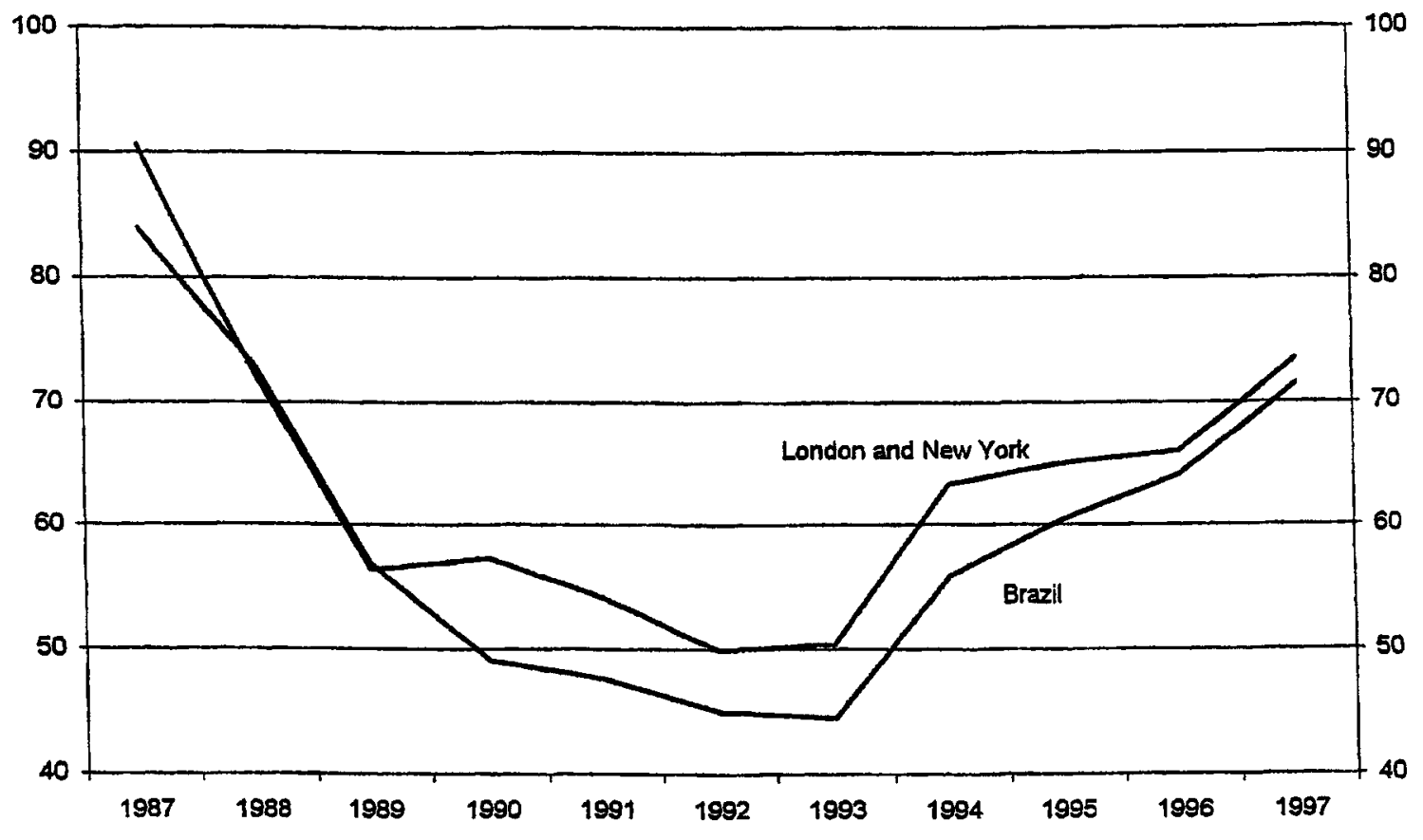

Source: MMF, International Financial Statistics 
Table 15. World Cocos Production, 1987-1997

\begin{tabular}{|c|c|c|c|c|c|c|c|c|c|c|c|}
\hline & 1987 & 1988 & 1989 & 1990 & 1991 & 1992 & 1993 & 1994 & 1993 & 1996 & 1997 \\
\hline & \multicolumn{11}{|c|}{ (in thousands of metric tons) } \\
\hline Production & 2,044 & 2,452 & 2,460 & 2,511 & 2,347 & 2,373 & 2,506 & 2,538 & 2,962 & 2,978 & 2,918 \\
\hline Cote dTwoire & 427 & 849 & 725 & 781 & 747 & 697 & 804 & 809 & 1,120 & 1,254 & 1,119 \\
\hline Ghama & 268 & 247 & 300 & 284 & 243 & 312 & 240 & 309 & 404 & 323 & 370 \\
\hline Indonesia & so & 49 & 111 & 142 & 169 & 175 & 258 & 270 & 305 & 318 & 333 \\
\hline Brazil & 329 & 392 & 393 & 356 & 321 & 329 & 341 & 330 & 296 & 257 & 293 \\
\hline \multirow[t]{2}{*}{ Malaysiz } & 190 & 227 & 225 & 247 & 230 & 220 & 220 & 177 & 131 & 120 & 120 \\
\hline & \multicolumn{11}{|c|}{ (In percent) } \\
\hline Share of world production & 100.00 & 100.00 & 100.00 & 100.00 & 100.00 & 100.00 & 100.00 & 100.00 & 100.00 & 100.00 & 100.00 \\
\hline Cóte d'livoire & 20.89 & 34.62 & 29.47 & 31.10 & 31.83 & 29.37 & 32.08 & 31.88 & 37.81 & 42.11 & 38.35 \\
\hline Ghoma & 13.11 & 10.07 & 12.20 & 11.31 & 10.35 & 13.15 & 9.58 & 12.17 & 13.64 & 10.85 & 12.68 \\
\hline Indonesia & 2.45 & 2.00 & 4.51 & 5.66 & 7.20 & 7.37 & 10.30 & 10.64 & 10.30 & 10.68 & 11.41 \\
\hline Bmzil & 16.10 & 15.99 & 15.98 & 14.18 & 13.68 & 13.86 & 13.61 & 13.00 & 9.99 & 8.63 & 10.04 \\
\hline \multirow[t]{2}{*}{ Malayaiz } & 9.30 & 9.26 & 9.15 & 9.84 & 9.80 & 9.27 & 8.78 & 6.97 & 4.42 & 4.03 & 4.11 \\
\hline & \multicolumn{11}{|c|}{ (In k8 per hectare) } \\
\hline World's average yield & 388 & 448 & 446 & 473 & 429 & 435 & 442 & 441 & 481 & 484 & 483 \\
\hline Cote divoire & 632 & 707 & 604 & 624 & $\$ 34$ & 536 & $\$ 54$ & 584 & 574 & 583 & 560 \\
\hline Ghana & 202 & 278 & 333 & 284 & 243 & 312 & 240 & 281 & 425 & 403 & 435 \\
\hline Indoneaia & 806 & 700 & 818 & 896 & 920 & 925 & 861 & 833 & 919 & 957 & 1,074 \\
\hline Branil & 507 & 559 & 595 & 536 & 481 & 449 & 464 & 473 & 402 & 376 & 404 \\
\hline \multirow[t]{2}{*}{ Malaysia } & 1,024 & 975 & 855 & 830 & 711 & 629 & 723 & 661 & 626 & 597 & 609 \\
\hline & \multicolumn{11}{|c|}{ (in U.S. cents per pound) } \\
\hline \multicolumn{12}{|l|}{ World prices } \\
\hline Brazil & 83.96 & 72.68 & 56.85 & 49.07 & 47.54 & 44.99 & 44.47 & $\$ 5.91$ & 60.46 & 64.07 & 71.40 \\
\hline \multirow[t]{2}{*}{ London and New York } & 90.62 & 71.84 & 56.34 & 57.32 & $\$ 4.1$ & 49.87 & 50.41 & 63.31 & 64.98 & 66.01 & 73.43 \\
\hline & \multicolumn{11}{|c|}{ (In U.S. dollar per motric ton) } \\
\hline \multicolumn{12}{|l|}{ Export price $1 /$} \\
\hline Cote divoire & 2,177 & 2,008 & 1,800 & 978 & 965 & 1,099 & 1,400 & 1,395 & 1,301 & $\$, 250$ & 1,387 \\
\hline \multirow[t]{2}{*}{ Ghana } & 2,102 & 1,490 & 1,309 & 1,290 & 1,237 & 1,000 & 950 & 1,238 & 1,522 & 1,374 & 1,473 \\
\hline & \multicolumn{11}{|c|}{ (In U.S. dollars per metric ton) } \\
\hline \multicolumn{12}{|l|}{ Producer price $1 /$} \\
\hline Cóte dTvoire & 1,339 & 1,282 & 1,308 & 717 & 740 & 722 & 430 & 609 & 631 & 572 & 763 \\
\hline \multirow[t]{2}{*}{ Ghana } & 699 & 634 & 584 & 625 & 542 & 432 & 317 & 561 & 739 & 668 & 799 \\
\hline & \multicolumn{11}{|c|}{ (In percent) } \\
\hline \multicolumn{12}{|c|}{ Distribution of fo.b. export rovenue $1 /$} \\
\hline Côte dTvoire & 100.00 & 100.00 & 100.00 & 100.00 & 100.00 & 100.00 & 100.00 & 100.00 & 100.00 & 100.00 & 100.00 \\
\hline Producers & 61.49 & 63.84 & 72.64 & 73.37 & 76.63 & 65.70 & 30.70 & 43.62 & 48.47 & 45.71 & 55.00 \\
\hline Marketing costs & 26.53 & 23.35 & 13.48 & 12.55 & 21.03 & 20.34 & 33.73 & 22.66 & 20.05 & 20.74 & 18.36 \\
\hline Taxes & 11.98 & 12.82 & 13.88 & 14.09 & 2.34 & 13.96 & 35.57 & 33.72 & 31.48 & 33.54 & 26.64 \\
\hline Ghana & 100.00 & 100.00 & 100.00 & 100.00 & 100.00 & 100.00 & 100.00 & 100.00 & 100.00 & 100.00 & 100.00 \\
\hline Producers & 33.25 & 42.56 & 44.62 & 48.49 & 43.79 & 43.23 & 33.36 & 45.32 & 48.56 & 48.62 & 54.26 \\
\hline Marketing costs & 43.57 & 27.65 & 28.31 & 27.87 & 41.67 & 33.40 & 19.36 & 20.71 & 16.26 & 19.50 & 19.58 \\
\hline Taxes & 23.18 & 29.79 & 27.07 & 23.64 & 14.55 & 23.36 & 47.28 & 33.97 & 35.18 & 31.89 & 26.16 \\
\hline
\end{tabular}

Source: FAO Yearbook; Intemational Financial Statistics; and data provided by the Ghanaian and Ivoirien authorities.

1/ The data is for the crop year beginning in the year reported at the top of each column.

$2 /$ Inchudes stabilization mangins. 
103. While cocoa production has given rise to many econometric studies, it is not easy to identify precisely the factors behind the relative expansion in cocoa production during the last decade. Price effects, for example tend to affect production with long delays because of the time it takes for a cocoa tree to begin production. Moreover, a cocoa tree once it reaches maturity it will continue to produce even when given only minimal care. Comparative advantage in production is likely to play a role in making cocoa production more profitable in a country than in another. Data on cocoa yield per hectare show that during 1987-97 Indonesia and Côte d'Ivoire had yields per hectare that were on average 2 to 3 times higher than those in Ghana (Figure 13). These differences are explained mostly by the use of high yield hybrid varieties, but also by better husbandry. ${ }^{36}$

104. However, higher yields are no guarantee of success in world cocoa markets and by themselves can not explain why the production in certain countries had grown faster than in others. Malaysia and Brazil have yields per hectare that are close to those in Indonesia and Côte d'Ivoire, respectively, but have lost significant market share during this decade (from 25 percent of world production in 1987 to 14 percent in 1997). The main problem in these countries seems to have been a profit squeeze resulting from declining cocoa prices and competition from alternative opportunities for the use of the factors of production, particularly labor, that had been employed in cocoa production. The outbreak of cocoa diseases also played a role in the decline of cocoa production in Brazil and Malaysia. Nevertheless, available evidence points to the importance of underlying economic incentives-such as production costs, domestic producer prices, and profitability of alternative crops-in determining production levels, albeit not necessarily in the short term.

105. Assuming that prices of cocoa are determined in world markets, and abstracting differences in quality, the nominal price paid to cocoa farmers depend mainly on marketing, extension services, financial costs, and taxes. ${ }^{37}$ Data for 1995 indicate that different countries chose to distribute cocoa proceeds in markedly different ways among producer payments, marketing costs, and taxes (Table 16). The producer share in cocoa revenue is much lower in Côte d'Ivoire and Ghana than in any of the other producers listed below, all of which have more liberal cocoa marketing systems. Moreover, both marketing costs and taxes were higher in these two countries than in any of the other five countries. The next section compares

\footnotetext{
${ }^{36}$ Part of the yield differences between neighboring countries, such as Ghana and Côte d'Ivoire, could be explained by smuggling of cocoa from one country to the other in response to differences in producer prices (which raise apparent yields in the importing country while reducing apparent yields in the exporting country).

${ }^{37}$ Other important factors are exchange rates and domestic prices, as they determine how much the cocoa farmer receives in terms of other goods he can purchase. For simplicity's sake, marketing costs will henceforth encompass marketing, extension services and financial costs.
} 
production incentives, marketing arrangements and other production characteristics between Côte d'Ivoire and Ghana in more detail.

\section{Comparisons with Côte d'Ivoire}

106. Côte d'Ivoire and Ghana are neighboring countries, but have different marketing systems, although in both countries the government still has a predominant role in managing the system.

\begin{tabular}{|lccc|}
\hline \multicolumn{4}{c|}{ Table 16. Distribution of Cocoa Export Proceeds, 1995 } \\
(in percent)
\end{tabular}

Source: Varangis and Schreiber (1996); and Fund staff estimates for Côte d'Ivoire and Ghana.

107. Côte d'Ivoire's cocoa production increased at an average annual rate of 10 percent during 1987-97; while Ghana's production increased at an average annual rate of only 3 percent only during the same period. As Figure 16 shows, marked changes in Côte d'Ivoire's production took place in 1988 and in 1995 and explain much of the performance for the decade. The increase in 1988 seems to have its origins earlier in the eighties, when higher producer prices and government incentives convinced Ivoirien farmers to use higher yielding hybrid varieties. Output tended to stagnate in the first half of the nineties, as an overvalued exchange rate and sharply lower farmgate prices eroded producer incentives. The CFA devaluation and rising world prices for cocoa reinvigorated production in the 1995/96 season.

108. Ghana's production fell dramatically in the seventies and the first half of the $1980 \mathrm{~s}$ owing to excessive taxation, and misguided economic policies. For example, in the 1983/84

\footnotetext{
${ }^{38}$ For additional information on Côte d'Ivoire's cocoa developments, see IMF (1998).
} 
Figure 16. Cote d'Ivoire and Ghana: Production Trends, 1987-98

(In thousands of metric tons)

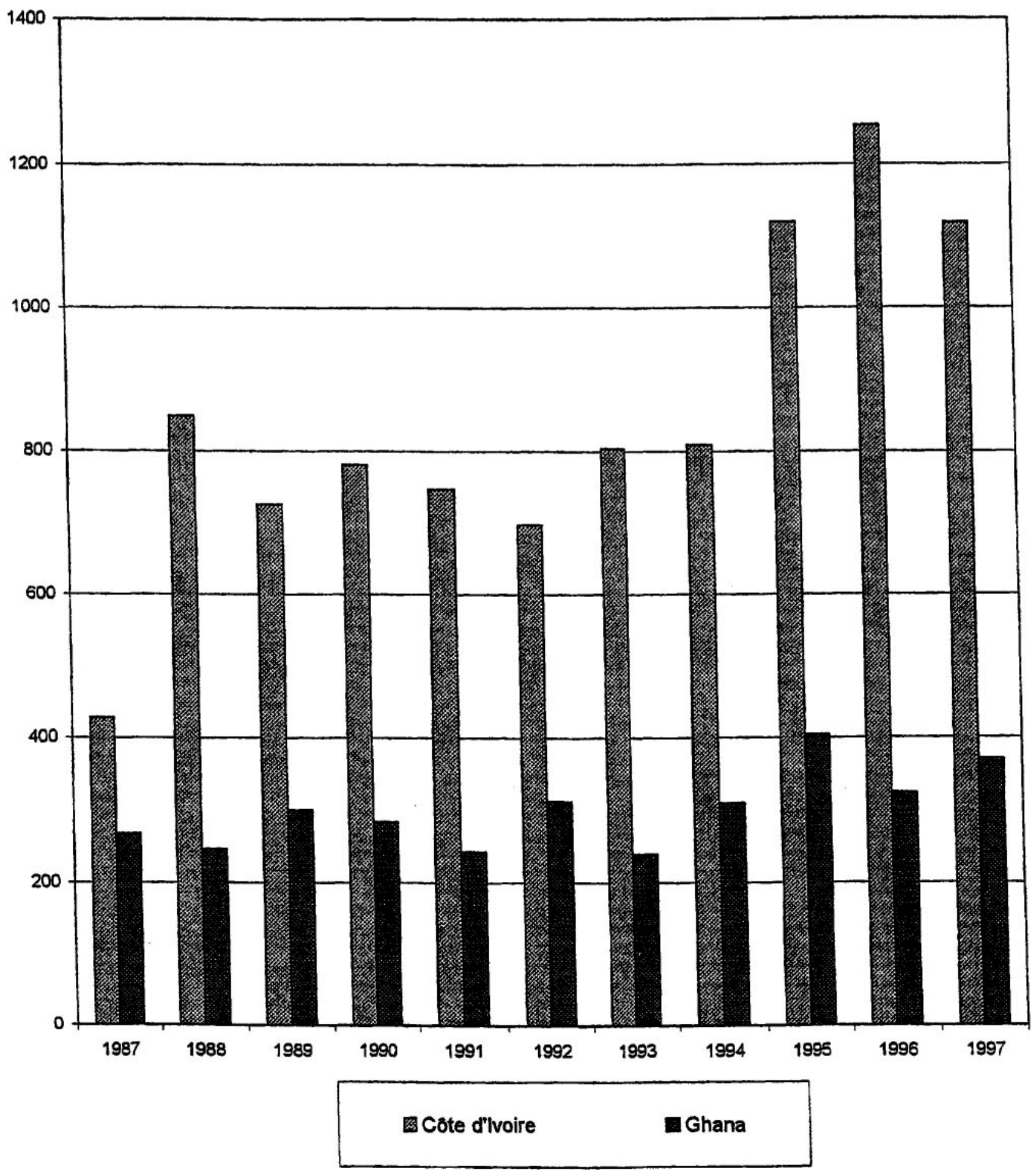

Sources: FAO Yearbook 
crop season, the share of taxes in cocoa export revenue was as high as 44 percent. From 1986 onward, however, Ghana's production has had a steady, if unspectacular growth, helped by policy reforms aimed at restoring macroeconomic stability and farmers' incentives (see Section $\mathrm{D}$ below).

109. Figure 17 compares export and producer prices between Côte d'Ivoire and Ghana during the period $1987 / 88-1997 / 98$. The comparison is subject to some uncertainty because Côte d'Ivoire's cocoa export proceeds were only available in CFA francs and their conversion to US dollars depends on the exchange rate used. For this study, it was assumed that $1 / 3$ of the crop was exported in a calendar year and $2 / 3$ in the next calendar year; the exchange rate used took this factor into consideration. Two main conclusions can be reached from these comparisons.

110. First, despite the premium that Ghana's cocoa is supposed to command in world markets, the average price obtained by Côte d'Ivoire was often higher than that of Ghana in the last decade. This result is surprising, but may be the result of better timing of cocoa sales, or better ability to negotiate high prices owing to Côte d'Ivoire's higher market share. It raises doubts about the cost-effectiveness of Ghana's stringent quality controls, and about Ghana's strategy to sell cocoa for delivery later in the crop season-assuming that this is done to fetch higher export prices.

111. Second, producer prices in Ghana have been consistently below those in Côte d'Ivoire during the 1987-95 period (Figure 17), despite the fact that Ghana's cocoa normally fetches a premium in world cocoa markets on account of its higher quality. ${ }^{39}$ Only since then has Ghana's producer prices exceeded those in Côte d'Ivoire. It is worth mentioning, however, that even in recent years it is not clear that the higher producer prices translate into higher incentives to produce cocoa in Ghana than in Côte d'Ivoire. Costs of production are likely to be higher in Ghana than in Côte d'Ivoire, because Cocobod's insistence on quality control forces farmers to invest more time in readying the crop for purchase. Further, Ghana may have been disadvantaged by the pattern of exporting cocoa in smaller batches later in the season with the result that higher storage costs have to be paid. Since yields are lower and quality controls stricter in Ghana, cocoa farmers there may still have lower profits per unit sold than in Côte d'Ivoire.

112. In a recent study, Aleš Bulir (1998) showed that the cocoa production trends in Ghana can be reasonably explained by price incentives: the real international price for cocoa, the real producer price, and the smuggling incentive, which is measured by the differential between the Ghanaian and Ivoirien producer prices in US dollar terms (see Box 2). These results suggest that an important part of the explanation for relative production trends may be found in

\footnotetext{
${ }^{39}$ This premium has, however, tended to decline in recent years as processors develop new techniques to compensate for quality differences in cocoa beans.
} 
Figure 17. Cocoa Prices, 1987/88-97/98

Export Price, f.o.b.

(U.S. dollar per metric ton)

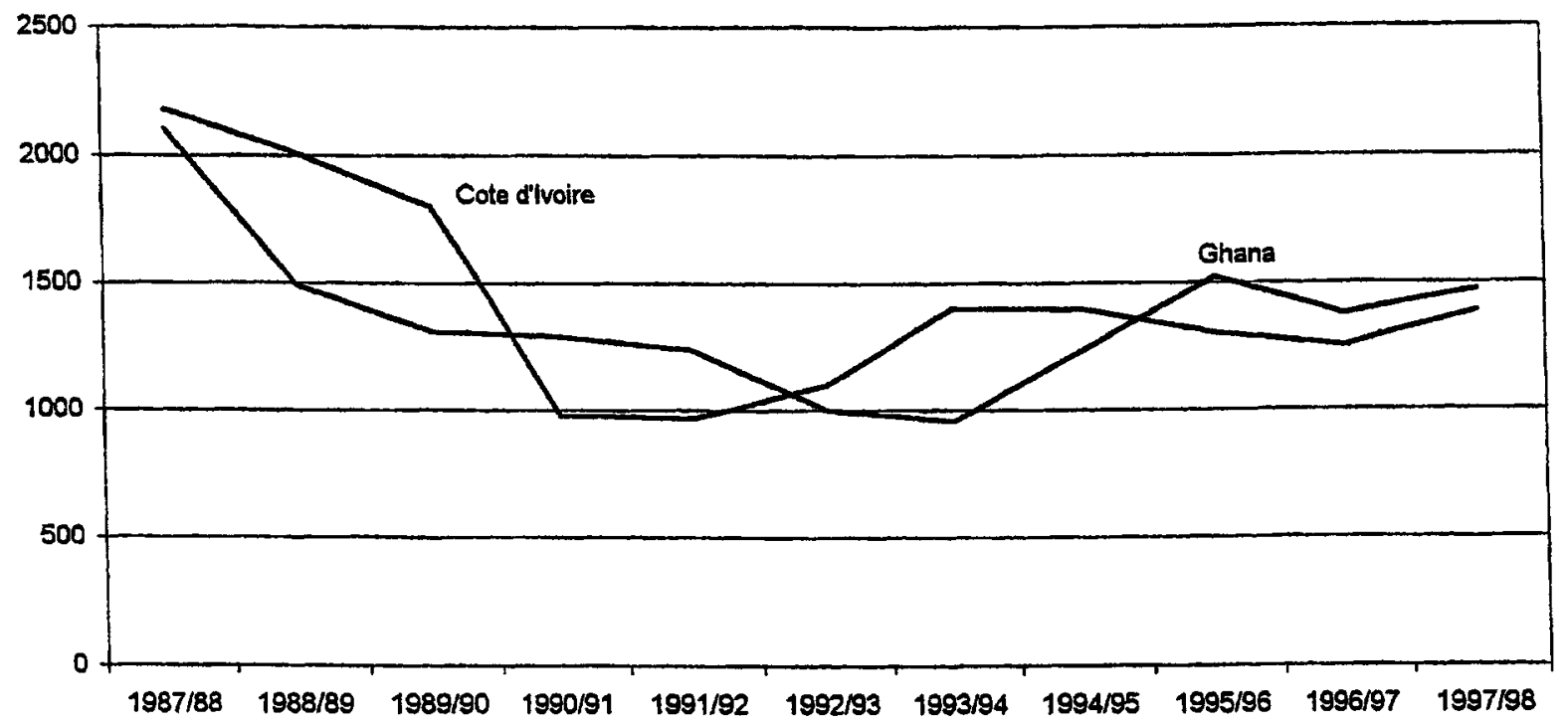

Producer Prices

(U.S. dollar per metric ton)

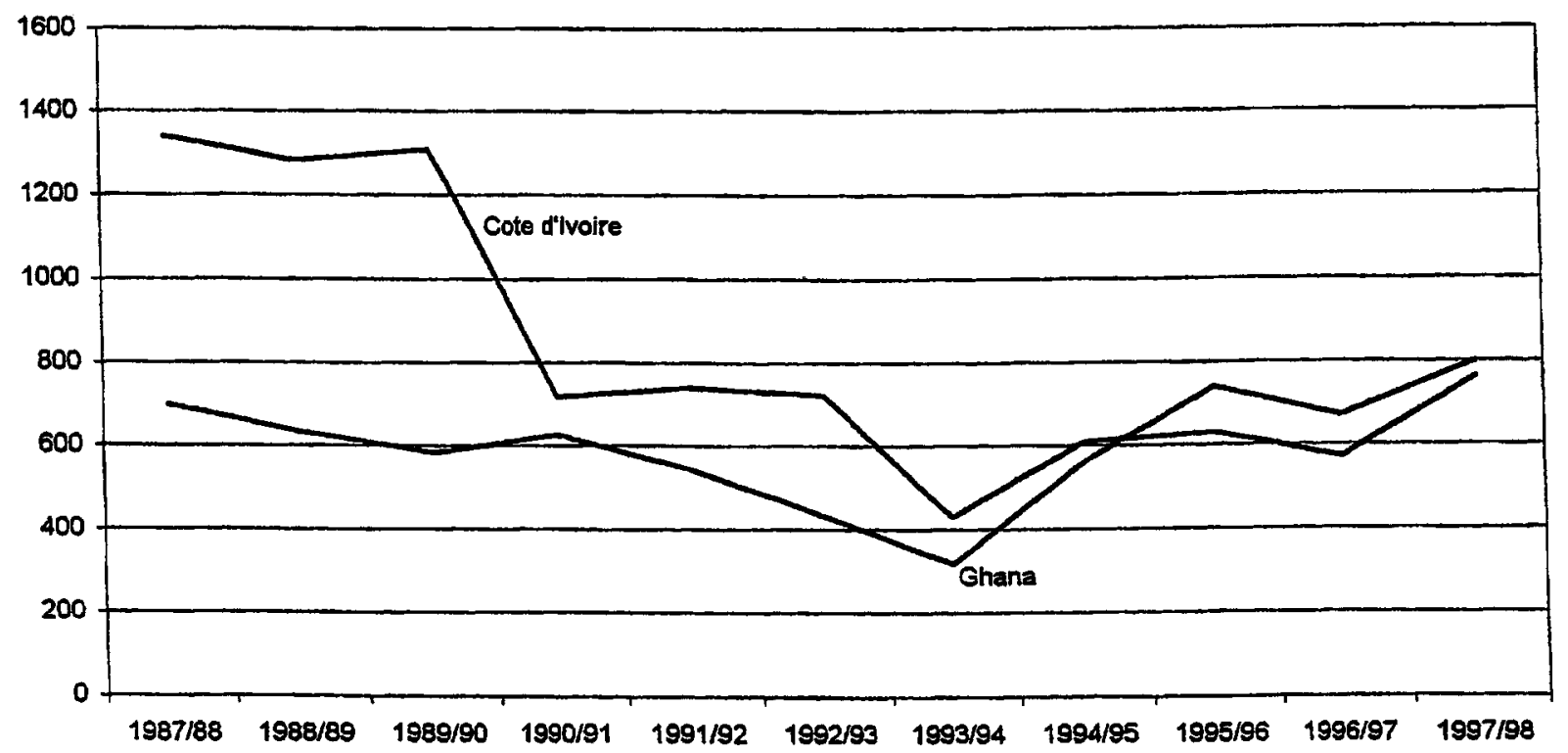

Sources: Data provided by the Ghanaian and the Ivoirien authorities and staff estimates 


\section{Box 2 . Cocoa Production and Tax Revenues}

From the early 1960 s to the early 1980 s, the officially recorded production of cocoa in Ghana declined by 60 percent. Ales Bulir (1998) tests whether price incentives could explain this trend. He uses three variables to measure price incentives: the real international price, the real producer price, and the differential between Ghanaian and Ivoirien producer prices in US dollar terms (the smuggling incentive). He concludes that, while there is little evidence of domestic short-term substitution between cocoa and other crops, the real international price and the smuggling incentive contribute significantly to explain cocoa production in Ghana.

Other points made in the paper:

- The taxation of cocoa producers in Ghana has been generally higher than in most other cocoa producing countries.

- The producer-international price ratio has been generally below the levels in other producer countries; producer prices in Brazil and Malaysia and, up to 1993, in Cameroon and C6́te d'Ivoire averaged 60-80 percent of international prices.

- Buliri concludes that lower producer prices will only temporarily boost government revenue. The revenue impact of lower producer prices dissipates completely after two years; after that, government revenue will decline from its initial level as supply continues to drop.

- If the farmers' share of international price stabilizes in 1996-2000 at 55 percent (compared with a baseline scenario in which the farmers' share stabilizes at 50 percent), and assuming the smuggling incentive is zero, then, ceteris paribus, the supply of cocoa would rise to 440,000 metric tons in 2000 from 320,000 in 1995. As a result government revenue would increase by about 15 percent between 1996 and 2000 . However, too high an increase in the producer price would not raise supply by much in the medium term and would be detrimental to government finances. For example, raising the farmers' share to 65 percent would increase the annual supply only to about 460,000 metric tons, and government revenue would decline by 30 percent when compared with the baseline scenario.

- The speed of adjustment to long-run price changes is high: more than one-third of the deviation from the long-term equilibrium in the previous year translates into the current supply decisions made by farmers.

Source: Buliř (1998).

differences in real producer prices and, in the case of neighboring countries such as Ghana and Côte d'Ivoire, in relative producer prices.

113. Since producer prices tend to be higher in Côte d'Ivoire than in Ghana, Ghanaian farmers have diverted some of their crop across the border to Côte d'Ivoire helping boost its neighbors' production statistics. Bulir (1998) estimated that smuggling may have reduced Ghana's officially recorded supply of cocoa by as much as $40,000-60,000$ metric tons, while similarly raising Côte d'Ivoire's supply. Ghana's reluctance to increase domestic producer prices is explained by its dependence on cocoa taxes for a significant share of fiscal revenue 
and the fact that the Cocobod would need to streamline its operations and shed personnel, if it were to reduce its marketing costs. Table 17 provides an overview of the key differences between the marketing arrangements used in Côte d'Ivoire and Ghana during 1987-97.

\section{Ghana Cocoa Reforms, 1987-97}

114. The government has pursued reforms since the mid-1980s to reverse the decline in cocoa production that reached its all-time low in 1983/84. To encourage recovery, cocoa producer prices were raised by about 185 percent between the 1983/84 and the 1990/91 crop years, while improvements were made in the availability of inputs and extension services. Real price increases were achieved through a steady rise in the share of the cocoa export price paid to producers, specifically, from 25 percent in the 1986/87 crop year to 56 percent in the $1998 / 99$ crop year. Moreover, the Ghanaian authorities seem to be following closely developments in cocoa marketing across the border in Côte d'Ivoire and making sure that smuggling incentives are minimized. In fact, since 1994/95 crop season, the distribution of cocoa export revenue among producers receipts, marketing costs, and taxes has been almost exactly the same as in Côte d'Ivoire (Figure 18).

115. In order to achieve the targeted increase in the farmers' share in cocoa revenue, the government had to take steps to upgrade the efficiency of the cocoa marketing and distribution system, including reductions in the operating costs of the Cocobod. In 1987, the staff of the Cocobod was reduced by nearly 12,000 , in part by limiting its role in road haulage and construction and maintenance of cocoa feeder roads. By 1990, the share of haulage provided by the Cocobod was reduced to no more than 10 percent, with the private sector and railways increasing their participation. Simultaneously, the Cocobod embarked on a program to further reduce its staff during 1992-94, resulting in a reduction of its labor force by about 5,000 . To further help reduce marketing costs-thereby allowing producers' share of cocoa revenue to rise-the government in March 1992 permitted private traders to compete with the Produce Buying Company (PBC) in the purchasing of cocoa. Nevertheless, the PBC still accounts for about 70 percent of domestic crop purchases. 
Table 17. Cocoe Marketing Systems in Côte d'Ivoire and Ghana

\begin{tabular}{ll}
\hline \multicolumn{1}{c}{ Feature } & \multicolumn{1}{c}{ Côte d'Ivoire } \\
\hline Key agency & Caisse de Stabilization (CAISTAB) \\
Type of marketing arrangement & Price stabilization fund \\
Harvest season & $\begin{array}{l}\text { Major crop is in October-January. } \\
\text { Most exports take place from } \\
\text { November through February }\end{array}$ \\
Domestic purchase & \\
& $\begin{array}{l}\text { Canried out by 700 licensed traders } \\
\text { within a cost and price structure } \\
\text { established by CAISTAB at the } \\
\text { beginning of each crop year } \\
\text { (including indicative producer } \\
\text { prices). }\end{array}$ \\
\hline
\end{tabular}

Domestic price determination

Taxation

Marketing costs and margins

Producer prices
Government, through CAISTAB; uses a price/margin structure for each stage of the marketing chain (bareme)

About 26.6 percent of cocoa revenue in $1997 / 98$ (including stabilization margins).

On average, 21.2 percent of cocoa revenue in 1987-97

On average 57.9 percent of cocoa revenue in 1987-97. For 1997/98, producer prices were 55 percent of cocoa revenue.
Marketing board

Major crop is in October-March. Most exports take place during January-September. Stocks are held for longer periods than in Côte d'Ivoire, increasing costs.

Cocobod, through its subsidiary, the Produce Buying Company (PBC); since March 1992, private traders were also allowed to purchase the crop from farmers, but have to sell it to the Cocobod at a pre-agreed price. $\mathrm{PBC}$ purchased about 70 percent of the crop in 1996/97.

Government, based on recommendation by the Producer Price Review Committee, which consists of representatives from Cocobod, government, licensed buying companies and members of the farmers' association.

About 26.2 percent of cocoa revenue in 1997/98

On average, 27.1 percent of cocoa revenue in 1987-97

On average 44.2 percent of cocoa revenue in 1987-97. For 1997/98, producer prices were 54.3 percent of cocoa revenue. 
Table 17. Cocoa Marketing Systems in Côte d'Ivoire and Ghana

\begin{tabular}{|c|c|c|}
\hline Feature & Côte d'Ivoire & Ghana \\
\hline Stabilization fund & $\begin{array}{l}\text { CAISTAB sets aside resources } \\
\text { resulting from better-than-expected } \\
\text { export revenue and use it to } \\
\text { moderate domestic price declines } \\
\text { in years of declining world prices. }\end{array}$ & $\begin{array}{l}\text { Some stabilization could be } \\
\text { achieved since the cocoa tax is the } \\
\text { residual between the export } \\
\text { revenue and all domestic costs. In } \\
\text { practice, the main concern has } \\
\text { been to stabilize fiscal revenue. }\end{array}$ \\
\hline Exports & $\begin{array}{l}\text { Five large and about } 35 \text { smaller } \\
\text { licensed exporters; CAISTAB } \\
\text { auctions off export rights daily } \\
\text { using a computer-aided system; } \\
\text { CAISTAB directly negotiates and } \\
\text { sells up to } 15 \text { percent of the crop. }\end{array}$ & $\begin{array}{l}\text { The Cocobod, through its } \\
\text { subsidiary the Cocoa Marketing } \\
\text { Company (CMC) negotiates and } \\
\text { sells all exports of cocoa. CMC } \\
\text { has modest operating costs and a } \\
\text { good reputation in world markets. } \\
\text { Cocoa exports are often sold } \\
\text { forward. }\end{array}$ \\
\hline Transport & $\begin{array}{l}\text { CAISTAB used to apply a system } \\
\text { of transport cost equalization under } \\
\text { which transporters were } \\
\text { reimbursed on a ton-kilometer } \\
\text { basis. However, since the } 1995 / 96 \\
\text { crop, CAISTAB no longer } \\
\text { administers transport costs, which } \\
\text { are paid by traders directly (the } \\
\text { transport costs, as reflected in the } \\
\text { barème, should on average cover } \\
\text { the actual costs) }\end{array}$ & Done by PBC. \\
\hline Quality control & $\begin{array}{l}\text { CAISTAB is responsible for bean } \\
\text { quality control at the export stage, } \\
\text { but standards are less strict than in } \\
\text { Ghana. Quality has tended to } \\
\text { decline, as traders mix high- and } \\
\text { low-quality beans so as to increase } \\
\text { shipment volumes and revenues }\end{array}$ & $\begin{array}{l}\text { Cocobod's Quality Control } \\
\text { Division is responsible for quality } \\
\text { inspection, grading and } \\
\text { fumigation both up-country and at } \\
\text { the ports. It operates a thorough } \\
\text { quality control and grading system } \\
\text { that has successfully safeguarded } \\
\text { the quality reputation of Ghana's } \\
\text { cocoa, albeit at a significant cost. }\end{array}$ \\
\hline Financing & $\begin{array}{l}\text { Traders are the main source of } \\
\text { input financing to farmers. Large } \\
\text { traders use their own funds, while } \\
\text { smaller traders obtain funds from } \\
\text { large exporters. Exporters rely on } \\
\text { commercial banks for pre-export } \\
\text { finance. }\end{array}$ & $\begin{array}{l}\text { Crop and export financing is } \\
\text { arranged through the Cocobod, } \\
\text { which uses syndicated foreign } \\
\text { loans. }\end{array}$ \\
\hline
\end{tabular}


Table 17. Cocoa Marketing Systems in Côte d'Ivoire and Ghana

\begin{tabular}{lll}
\hline Feature & \multicolumn{1}{c}{ Côte d'Ivoire } & \multicolumn{1}{c}{ Ghana } \\
\hline Domestic processing & There is considerable domestic & In recent years, CMC sales to \\
& grinding capacity, currently of the & domestic processing plants have \\
order of about 250,000 tons per & been around 70,000 tons per year, \\
year. Domestic processors receive & mostly from its mid-crop, but also \\
a subsidy of about CFAF $100 / \mathrm{kg}$ & from the main crop. These sales \\
on beans they process to & are made at a discount below the \\
& compensate for the use of low & fob price, which is supposed to be \\
& grade beans for domestic & the equivalent of CMC's savings \\
processing & when compared with exported \\
& beans costs.
\end{tabular}

Source: Varengis and Schreiber (1996), and IMF staff. 
Figure 18. Cocoa Cost Structure, 1987/88-97/98

(In percent of export revenue)

Ghana

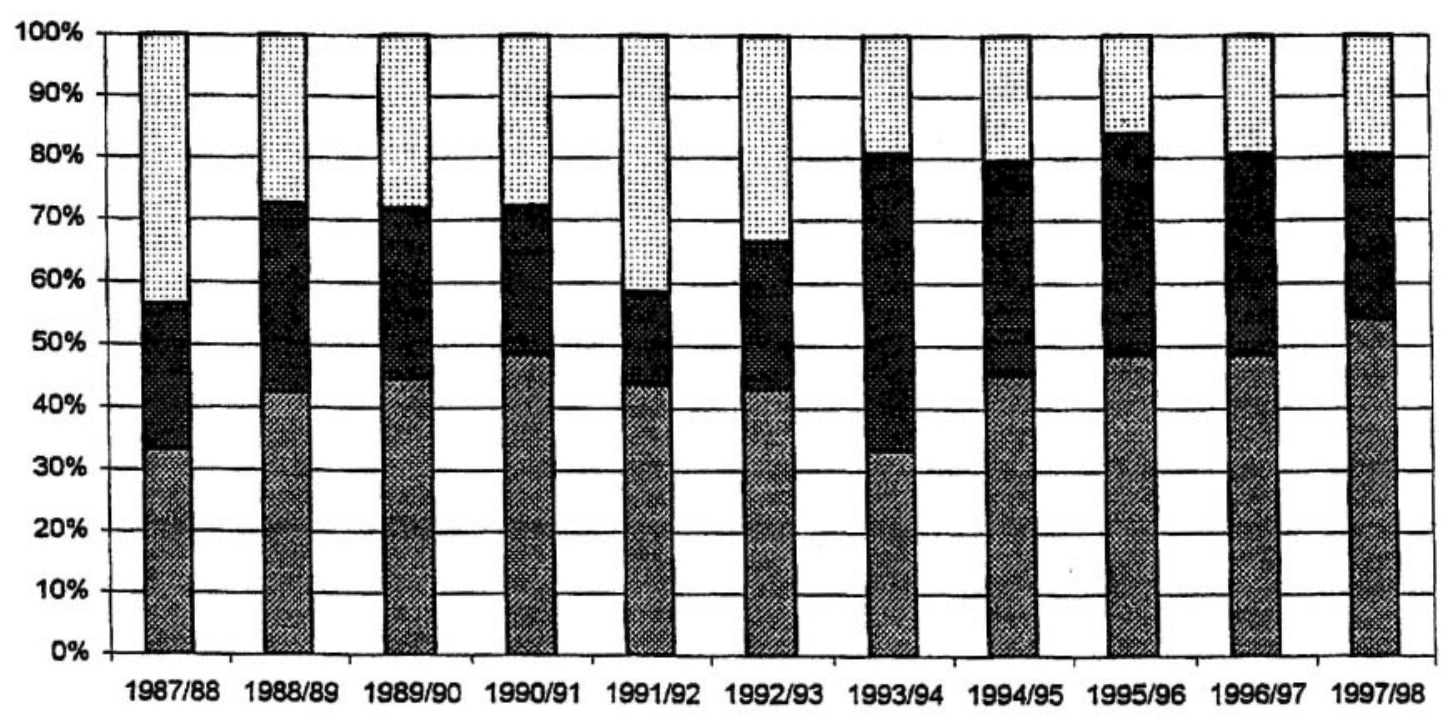

Cote d'Ivoire

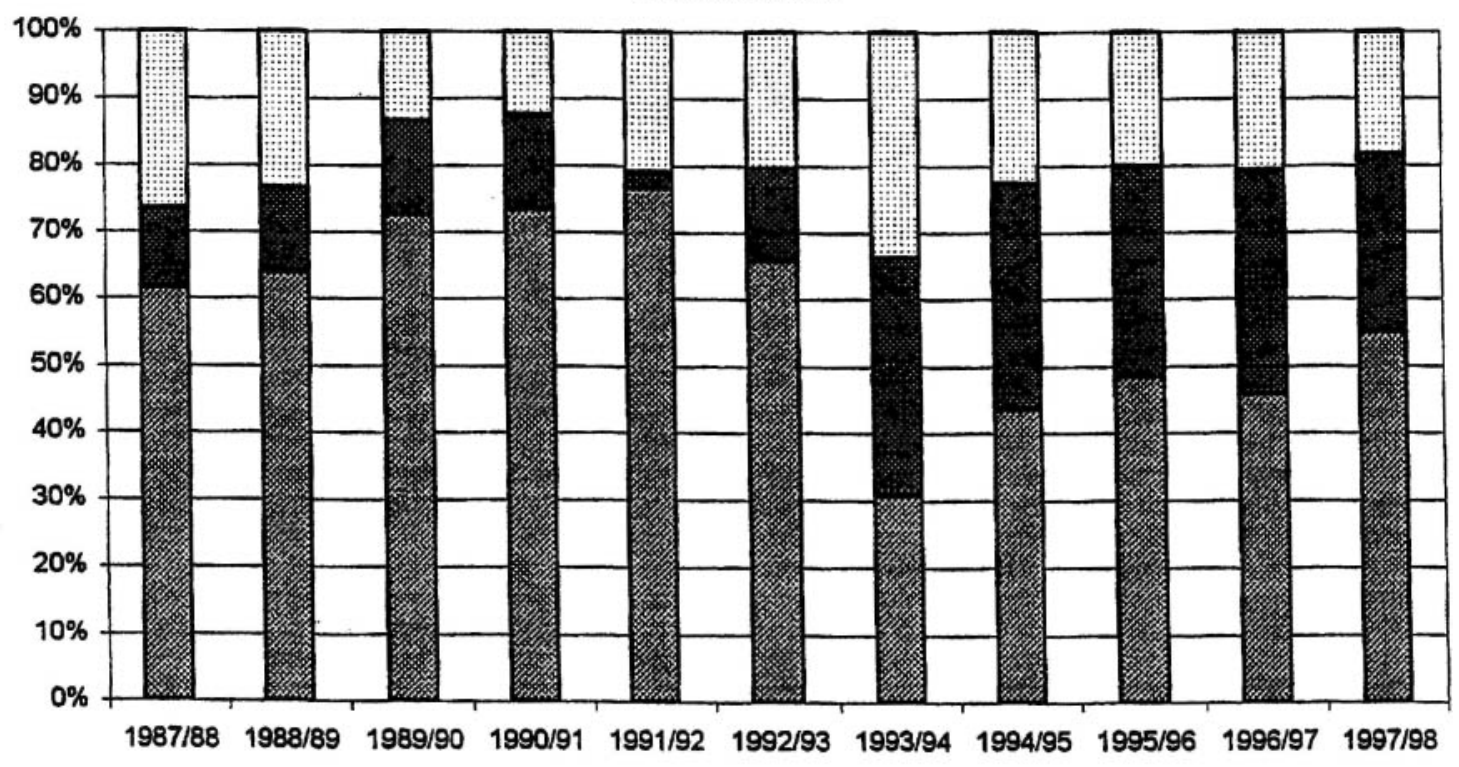

Producer

-

口Marketing

Sources: IMF staff estimates. 
116. In 1995, in its request for the current three-year ESAF arrangement, the government signaled its intention to remove the Cocobod's monopoly in cocoa exporting, while retaining its quality control function. A study was commissioned by the government and financed by the World Bank to examine the scope and pace of the cocoa sector reforms (LMC International (1996)). The study recommended a gradual approach to liberalization of cocoa marketing in Ghana. It proposed that the producers' share in export revenue be increased to about 65 percent in two years by withdrawing the Cocobod and its subsidiaries from the domestic purchases of cocoa beans, and by transferring extension services from the Cocobod to the Ministry of Agriculture (and the absorption of these services into the budget). The report claimed that any effort to increase the producers' share beyond 65 percent would require a reduction in cocoa taxes. ${ }^{40}$ It recommended that Cocobod's control of exports be maintained based on the perception that its removal might adversely affect quality control, reliability of deliveries, forward sales, and the predictability of export receipts and taxes.

117. The government has continued moving ahead cautiously toward greater liberalization of the cocoa sector while assessing its options to maintain the competitiveness of Ghana's cocoa. It has agreed to increase the farmers' share in the f.o.b. price of cocoa to 56 percent for the 1998/99 crop, to 58 percent for the 1999/2000 crop and to 60 percent for the 2000/01 crop. It has directed the Cocobod to prepare a two-year program of cost-cutting measures to support at least one half of the intended increase in the producers' share. The PBC will be offered for sale early in 1999 in a manner designed to foster competition in the domestic cocoa purchasing market. The Government is also unifying the extension services of the Cocobod and the Ministry of Agriculture, although costs associated with the reorganization of these services, including retrenchment, remain an obstacle that the government hopes to resolve with World Bank assistance.

\section{E. Next Steps and Conclusions}

118. Ghana's cocoa production is growing less than that of its close competitors.

Moreover, Ghana remains significantly more dependent on cocoa for foreign exchange earnings and tax revenue than its competitors and, therefore, more vulnerable to errors in its cocoa sector strategy. These factors call for the government to carefully assess its options, design a strategy, and implement it forcefully. The government has indicated that it plans, with World Bank assistance, to conduct a major workshop on cocoa sector reforms in January 1999 , with the objective of developing its strategy to deepen the cocoa sector reforms. The workshop will have work groups dealing with issues related to production, marketing, finance and infrastructure, and taxation and pricing.

\footnotetext{
${ }^{40}$ The report does not explicitly recommend tax reductions, although it states that the optimal tax (that is, the export tax that would maximize the exporting country revenue when faced with an inelastic demand for its exports) would be around 10-15 percent of export revenue. The report implies that any changes in cocoa taxes will need to be decided with an eye on their impact on the budget.
} 
119. Ghana's competitors are continuing their reforms, making it crucial for Ghana to accelerate its own reforms so as to strengthen its competitive position. Building on the reforms undertaken since the early 1990s, Côte d'Ivoire will further liberalize cocoa marketing beginning in October 1999, with the aim of strengthening the role of the private sector and increasing producers' income. The key elements of the reform schedule include the abolition of the indicative producer price, the elimination of the administrative price schedule (barème) and the stabilization system, and the liberalization of exports. These reforms are being supported by ongoing efforts to strengthen producer organizations and provide support to young farmers and women to ensure that these groups take full advantage of the liberalized system. The stabilization fund (CAISTAB) will be restructured and its mission will be limited to ensuring quality control, preparing statistics on production and exports, and monitoring marketing and stocks.

120. As LMC International Ltd (1996) states, "Given the weaknesses identified in Ghana's current marketing arrangements, no sustainable argument for maintenance of status quo can be made." There is therefore an urgent need for action in this area. Some tentative conclusions can already been drawn and could serve as a starting point for the deliberations at the forthcoming workshop on cocoa.

121. First, the experience of Ghana's competitors suggests that marketing costs can be reduced from their current level of 14-15 percent of the f.o.b. price to 10 percent. The first priority of the cocoa reforms should therefore be to lower marketing costs rapidly to not more than 10 percent of the f.o.b. price. Further reductions beyond this point would be more difficult to achieve.

122. Second, cocoa taxes are important for fiscal revenue in Ghana, and therefore reductions in cocoa taxes will need to be considered carefully. While initial tax reductions may not have a significant impact on fiscal revenue (see Bulii (1998)), further reductions certainly will. Thus, the timetable for reduction in cocoa export taxes would need to be closely coordinated with other revenue-enhancing tax reforms.

123. Third, quality control has resulted in a premium for Ghanaian cocoa in the world market. However, this premium is declining and is not clear that it would continue to be a net advantage in the future. Quality control is likely to decline with liberalization as it has happened in other countries. Increasingly, importers are carrying out their own tests on the commodities they buy irrespective of official certificates. Therefore, Ghana will need to ponder what changes in quality control procedures it should introduce to ensure that the benefits from quality control exceed its costs.

124. Fourth, Ghana normally ships cocoa later than Côte d'Ivoire. In doing so it incurs higher storage costs. Available evidence seems to indicate that ensuring shorter times between domestic purchases and shipments is likely to result in a net profit for Ghana. Also, there is no 
reason why cocoa storage operations should be undertaken by the Cocoa Board. Both these aspects of cocoa marketing need to be re-examined urgently.

125. Fifth, cocoa sales to domestic processors have tended to be below world prices representing an implicit subsidy. There seems to be no justification for this practice. The authorities could discontinue the subsidies and use the savings to increase producers' prices.

126. Sixth, the Cocobod has an arrangement with a large European cocoa processor to process cocoa beans into cocoa liquor, which is then delivered in liquid form to chocolate manufacturers in Europe. This aspect of Ghana's cocoa marketing has been criticized by traders, processors and manufacturers outside Ghana for its lack of transparency, and may need to be reconsidered. ${ }^{41}$

127. Seventh, a careful analysis of the advantages and disadvantages of forward sales needs to be made. It is true that it may initially be more difficult to sell cocoa forward in a situation of many exporters. CMC's good reputation as a counter-party is well deserved and it may take time for other Ghanaian cocoa exporters to establish similar reputations. The reduction in the share of the crop sold forward will increase uncertainty for producers, taxes and balance of payment forecasts. These difficulties need to be seen in perspective, however. Most commodity markets are not dominated by forward contracts, and still are able to function effectively.

128. Eighth, Ghana meets its financing needs for cocoa exports and domestic purchases through a syndicated loan in the international market. Liberalization of cocoa exports and marketing would mean that individual exporters and traders will need to find their own financing. Importers are likely to finance most of the exports, but domestic marketing will have to be done through the domestic banking sector. Since domestic banks may need to look for new loans anyway as the fiscal deficit declines, there is no reason to believe that this financing will not be forthcoming. It is true, however, that overall interest costs may be higher in the case of liberalization than under present conditions.

129. Ninth, as Varangis and Schreiber (1996) point out, the government should begin implementing a program to prepare the sector for further reforms. It could provide training of local operators to improve their knowledge of world cocoa markets; it could set up or strengthen professional associations dealing with cocoa trade, including farmers' associations and their management; and it could provide increased market information to all participants in the cocoa economy.

\footnotetext{
${ }^{41}$ Amoah (1998).
} 


\section{References}

Amoah, V. E. K., 1995, Development of Consumption, Commercial Production, and Marketing (Ghana, Accra: Jemre Enterprises). Entreprises). 1998, Marketing of Ghana Cocoa, 1885-1992 (Ghana, Accra: Jemre

Bulír, Aleš, 1998, "The Price Incentive to Smuggle and the Cocoa Supply in Ghana, 195096," IMF Working Paper, WP/98/88, June.

IMF, 1998, Côte d'Ivoire: Selected Issues and Statistical Appendix, IMF Staff Coutnry Report No. 98/446, May.

LMC International Ltd, 1996, The External Marketing of Ghana's Cocoa, June.

Varangis, P. N. and G. A. Schreiber, 1996, Cocoa Marketing and Pricing in West Africa, World Bank, May 31, 1996 
A. Central government

1. Taxes on income and profits

\subsection{Tax on companies}

1.11. Tax on company income Income Tax Decree, 1975 (S.M.C.D. 5); Income Tax (Amendment) Decree, 1977 (S.M.C.D. 129); Income Tax (Amendment Decree, 1978 (S.M.C.D. 195); Income Tax (Amendment) Act, 1980 (Act 398); Income Tax (Amendment) (No. 2) Act, 1980 (Act 419); Income Tax (Amendments) by Decree P.N.D.C.L. 39, 1982; 61, 1983; 127,$1985 ; 166,1986 ; 177,183$, and 192,$1987 ; 205,1988 ; 222$, $1989 ; 231,1990 ; 270,1991 ; 303$. 1992; and Income Tax Regulations L1252 and L1511.
Domestic and foreign companies operating in Ghana are taxed on taxable income accruing in, derived from, brought into, or received in the country. Taxable income includes net profits, interest, royalties, and rent income of companies formed exclusively for real estate development but excludes dividends from other companies. Prior to 1989, the assessment year ended June 30 and tax was payable annually. Following the 1983 budget, all income tax assessments are on a calendar year basis, payable quarterly in arrears. For tax purposes, net profit is assumed to be not less than 5 percent of turnover unless the company is within its first five years of assessment. However, this is waived with respect to companies engaged in mining or farming, and with 10 consecutive years of assessment, or companies that have maintained adequate books of accounts and submitted reliable records for 10 consecutive years of assessment to the satisfaction of the Commissioner. For domestic subsidiaries of nonresident companies, a further floor to net profits exists in that the subsidiary's share of the consolidated group profits should at least be equal to the subsidiary's share of group turnover.
Exemptions include the income from cocoa farming, income of other agricultural companies during the first five years of operation, and the income of some public enterprises (e.g., Bank of Ghana and COCOBOD). Deductions allowed include expenditures incurred in the production of income, including interest and rent. Losses incurred in farming are offset and carried forward for two years. Since 1995 a loss incurred can be carried forward for the next five years following the year in which the loss was incurred. This provision is effective for manufacturing, real estate, and all enterprises. Insurance companies have no time limit.
The basic tax rate is 35 percent.

Initial depreciation allowances:

$\begin{array}{lc}\text { Buildings } & \text { Percent) } \\ \begin{array}{l}\text { Agricultural } \\ \text { plantations }\end{array} & 10 \\ \begin{array}{l}\text { Mining (exploration and } \\ \text { capital expenditure) }\end{array} & 10 \\ \text { Plant expenditure } & 20 \\ & 20\end{array}$


Ghana: Summary of Tax System, May 1997

$\operatorname{Tax}$

1.11 Tax on company income (continued)
Nature of Tax

Exemptions and Deductions

Rates

Initial depreciation allowances

(continued):

A further investment allowance of

5 percent is available for capital

expenditure by industrial concerns.

Annual depreciation allowances:

Buildings

(Percent)

(mining and

timber companies)

(other)

Mining (exploration and

capital expenditure)

3

Plant expenditure

Investment allowance: Granted at 5

percent to industrial firms for capital capital expenditure on plant and

machinery (in the year of

investment)

A further depreciation allowance of 10 percent is available to companies maintaining a sinking fund for the replacement of plant and buildings in a separate bank account, provided that the accrued addition to the sinking fund exceeds the value of all capital allowances.

Companies engaging in non-

traditional exports (other than cocoa and coffee beans, timber logs,

electricity, unprocessed gold or any other mineral) are subject to a

concessionary tax rate of 8 percent. 
1.12 Casino tax

Casino Revenue Tax Decree, 1973

(N.R.C.D. 200); Gambling Machine

Decree, 1973 (N.R.C.D. 174);

Casino Revenue Tax (Amendment)

Decree, 1974 (N.R.C.D. 267);

Gambling Machines (Amendment)

Decree, 1974 (N.R.C.D. 276);

Casino Revenue Tax (Amendment)

Decree, 1976 (S.M.C.D. 45); and

Budget 1985.

1.2 Taxes on individuals

1.21 Income tax

Income Tax (Amendment) Decree, 1969 (N.L.C.D. 377); Taxation Act, 1970 (Act 330); Taxation (Amendment) (No.2) Act, 1970 (Act 344); Income Tax (Amendment) Act,

1971 (Act 388); Taxation (Amendment) Decree, 1972 (N.R.C.D. 97); (Standard Assessments) Instrument, 1968 (L.I. 590); Income Tax
Tax is levied as an annual license fee on each gambling table and slot machine. companies located outside Accra receive the following rebates: Accra-Tema: No rebate. All other regional capitals: 25 percent of tax liability All other places: 50 percent of tax liability.

None.

This tax is payable, subject to the deductions and exemptions noted, on income received by, or accruing to, persons in Ghana.

In addition to wages and salaries, income includes profits, nonbank interest receipts, dividends (which are taxed at the source at 10 percent, final tax), royalties, pensions, rental income and payments in kind (other than dental and medical costs).

\section{Exemptions include:}

(a) income derived from cocoa production;

(b) income derived from farming for

an initial period of 3-10 years;

(c) interest on savings accounts;

(d) retirement and sickness annuities;

(e) armed forces disability pensions;
The annual license fee is C 150,000 per casino table in Accra, $C 80,000$ per casino table elsewhere, and $\mathbb{C} 20,000$ per slot machine. 
Ghana: Summary of Tax System, May 1997

Tax

Nature of $\operatorname{Tax}$

Exemptions and Deductions

Rates

1.21 Income tax (continued)

(Standard Assessments) (Amendment) Instrument, 1977 (L.I. 1120); Income Tax (Amendment) (No. 2)

Act, 1981; Income Tax (Amendment) Act, 1983; and Income Tax (Amendment) Acts of 1984, 1985, $1986,1987,1988$, and 1989; and P.N.D.C.L. 96, 127,'166, 127, 116, 117 , and 183.
Standard assessments, now known as quarterly/monthly/daily advance tax payments, are applied on certain categories of small business owners and self-employed professionals in the course of determining their actual liabilities. (f) widows' and orphans' pensions. Additionally, the income of a wide variety of charitable, educational, religious, and research institutions is exempt.
Deductions include a married man's allowance of $\mathbb{C} 200,000$ (also for a married woman with a dependent husband and unmarried men and women with two or more dependent children), social security and provident fund contributions, and life insurance premiums (up to . (C 240,000 and not exceeding 10 percent of the sum assured). A deduction of $C 240,000$ per dependent child attending secondary school is provided. A disablement relief of 25 percent of income from self-employment is provided to disabled persons, while selfemployed persons above 60 years of age are granted relief amounting to C 300,000 of chargeable profits.

Other deductions include 30 percent of rental income as well as rates and mortgage interest relating to the property.
Taxable Income Nonconsolidated Tax rate

$$
\text { wages }
$$

First C 318,000

Next C 522,000

Next C $1,080,000$

Next $C 6,480,000$

Next C $7,600,000$

Over \& $16,000,000$

in percent 
$\operatorname{Tax}$

1.22 Capital gains taxes Capital Gains Tax Decree, 1975 (N.R.C.D. 347) as amended in 1976 (S.M.C.D. 46); Budget 1984 and P.N.D.C.L. 198, 232, and 267.

2. Social security contributions

Social Security Decree, 1973

(N.R.C.D. 127)

3. Payroll taxes (other than social security contributions)

3.1 Selective alien employment tax

Selective Alien Employment Decree, 1973 (N.R.C.D. 201); Selective Alien Employ ment Tax (Amendment) Decree, 1974

(N.R.C.D. 248); Selective Alien Employ ment Tax (Amendment) (No. 2) Decree, 1974 (N.R.C.D. 268); Budget 1985; P.N.D.C.L. 196.

\section{Nature of Tax}

This tax is levied on realized capital gains from the sale of buildings, businesses, and business assets including goodwill, land, stocks and shares, and other assets determined by the authorities.

Realized capital gains are computed as the price received from the asset less the purchase price and allowable deductions.
Exemptions and Deductions

Rates

In addition to deducting the original purchase price of the asset from the realized sum, deductions are allowed for the cost of improvements and alterations. Capital gains arising during a merger, amalgamation, or reorganization of companies are exempt. Capital gains arising out of the disposal of securities of companies listed on the Ghana Stock Exchange are exempt for the first 5 years of the life of the Ghana Stock Exchange.

All establishments with five or more employees are required to contribute to the social security and national insurance trust fund. Contributions are based upon each employee's eamings, with contributions from both employer and employee. Employees' contributions are withheld at source. Other employees and self-employed persons may enroll on a voluntary basis.

Enterprises with fewer than five employees are exempt.

Expatriate employees in the

This tax is levied on both Ghanaian and foreign firms employing expatriate personnel. The tax is not deductible for income tax purposes. Beginning in 1995, the tax is administered by the Ghana Investment Promotion Centre.

following fields are exemp

(a) logging and saw milling;

(b) fishing;

(c) mining;

(d) oil prospecting;

(e) government departments and statutory corporations;
Tax payable on the assessed capital gain is computed at a flat rate of 5 percent.

Any gain up to $C 50,000$ is exempt.

$\begin{array}{lc}\text { Contribution } & \begin{array}{c}\text { Percent of } \\ \text { employee's } \\ \text { basic pay: }\end{array} \\ \text { by: } & 12.5 \\ \text { Employer } & 5.0\end{array}$

Tax is levied at the annual rate of $C 500,000$ for each expatriate employee. 
$\operatorname{Tax}$

Nature of Tax
Exemptions and Deductions

Rates
Selective alien employment tax (continued)

\section{Taxes on property}

4.1 Death and gift taxes

\subsection{Gift tax}

Gitt Tax Decree, 1975 (N.R.C.D.

348); and Budget 1984 as amended

by P.N.D.C.L. 195 and 233.
This tax is levied on the recipient of gifts of land,

buildings, securities, or money according to a

graduated rate, which increases with the total open market value of gifts received within any 12 -month period.

(f) manufacturers who have operated

in Ghana for less than five years;

(g) farming operations;

(h) missionaries of religious bodies;

(i) employees of hospitals (including

clinics and dressing posts) other

than government hospitals.

Asset transfers under a will are exempt, as are gifts between spouses and gifts between a parent and child.

Gifts to religious bodies and for

charitable or educational purposes are also exempt. Allowable deductions include gifts received up to $C 50,000$ in value in any 12 -month period, provided that the total value of gifts received in the last five years does not exceed $\mathbb{C} 50,000$ in value. Where the five-year total exceeds C 50,000, tax is payable on the balance received in the latest year.
Tax is payable according to a scale which increases with the value of gifts received.

Value of Gifts Rate of Tax (In cedis) (Percent)

0 - $50,000 \quad \mathrm{Nil}$ $50,001-250,000 \quad 5.0$ $250,001-500,000 \quad 7.5$ $500,001-750,000 \quad 10.0$ $750,001-1,000,000 \quad 12.5$ $1,000,001$ or more $\quad 15.0$ 


\section{Tax}

Nature of Tax

Exemptions and Deductions

Rates

5. Taxes on goods and services

5.1 General sales tax

\subsection{Sales tax}

Sales tax Act, 1965 (No. 257) and

Sales Regulations, 1965 (LI 389), as

amended through Sales Tax

(Amendment) Decrè̉e, 1973

(NRCD 196); Sales Tax Exemp-

tions (Amendment) Regulations,

1975 (LI 1026); Sales Tax (fees)

(Amendment) Regulation, 1975

(LI 1023); Budget 1985-91.

Sales Tax Act has been consolidated into: Customs, Excise and

Preventive Service (Management)

Law, Part IVA and IVB; Customs and Excise (duty rates and other taxes) Law, 1991 (P.N.D.C.L. 262); Budget 1992-96.

\subsection{Excise taxes}

5.21 Tobacco

Customs and Excise Tariff, 1973; Cigarettes (Special Tax) Decree, 1976 (S.M.C.D. 40); Cigarettes Special Tax (Amendment) Decree, 1977 (S.M.C.D. 111); Cigarettes (Special Tax Law), 1983

(P.N.D.C.L. 73); Bưdget 1985-96.
A single-state sales tax is levied on a wide variety of locally produced and imported goods at the manufacturer's level.

Manufacturers who are registered with CEPS may have the Import Sales Tax on Raw Materials deferred.

Special duties are applied to tobacco products,

None. both local production and imports.
Exemptions from sales tax include:

(a) animals, livestock, and poultry produced in Ghana:

(b) animals, livestock, and poultry imported for breeding purposes;

(c) animal product in its raw state produced in Ghana;

(d) agricultural and aquatic food product in its raw state produced in Ghana;

(e) seeds, bulbs, rootings, and other forms of propagation;

(f) agricultural inputs;

(g) fishing equipment and fish caught

by Ghanaian-owned vessels;

(h) all goods imported or purchased

for Missions etc.

(i) printed matter (books and newspaper);

(j) laboratory equipment for educational purposes and library equipment;

(k) machinery;

(l) crude oil and hydrocarbon

products; and

(m) goods for the disabled.
The sales tax rate is generally 15 percent on concessionary, consumption, and luxury goods. The rates are applied equally on the f.o.b. price on domestically produced goods and on the c.if. plus duty value of imports. 
Ghana: Summary of Tax System, May 1997

$\operatorname{Tax}$

5.22 Spirits and beer

Customs and Excise Tariff, 1973.

Beer (Special Tax) Decree, 1975

(N.R.C.D. 342); Beer and Stout

(Special Tax) (Amendment) Decree,

1977 (S.M.C.D. 110); 1983

(P.N.D.C.L. 72); Budget 1985-96

5.23 Luxury goods

Budget 1995

5.24 Petroleum products

Budget 1987-95.

5.25 Other excises

\subsubsection{Local duty on cocoa}

Cocoa (Local Duty) Ordinance,

1952; Cocoa Duty Decree, 1973

(N.R.C.D. 168); Cocoa Duty

Decree, 1974 (N.R.C.D. 265);

and Cocoa Duty (Amendment)

Decree, 1977 (S.M.C.D. 112).

All laws on excise taxes have

been consolidated into the

Customs, Excise and Preventive

Service (Management) Law,

Parts IVA and IVB; and the

Customs and Excise (duty rates

and other taxes) Law, 1991

(P.N.D.C. 262); Budget 1992-

96.
Ad valorem excise is applied to domestically None.

manufactured and imported luxury goods.

Specific excises are applied to petroleum products. None.

This tax is the domestic counterpart to the cocoa export tax (see 6.21 below) and is levied on the

Cocoa Marketing Board's sales of cocoa within

Ghana.
Exemptions and Deductions None.

Ad valorem excises are applied to alcoholic

beverages.

The levy is 100 percent duty cocoa sales by the Cocoa

Marketing Board after allowing for the producer price of cocoa and costs of the Board. 
5.3 Selective tax on services

\subsection{Airport tax}

Airport Tax Act, 1963 (No. 209);

Airport Tax (Amendment) Decree,

1973 (N.R.C.D. 203); Airport Tax

(Amendment) Decree, 1977

(S.M.C.D. 119); and Budget

1985-96.

5.32 Service tax
This tax is levied on passengers departing from airports for both domestic and international destinations. The tax is ceded to the Civil Aviation Authority.

Admission tickets for a wide variety of entertainment are taxed on the basis of the admission price:

Accommodation. This tax is an ad valorem levy on accommodations and food by hotels and restaurants.

Advertisement through all media.

Betting. This tax is levied on all sums wagered in regular betting, on the sums paid for licenses in sweepstakes, or price money paid from football pools.
None.

The tax is levied at $\mathbb{C} 22,000$

for intemational flights and

e 500 for domestic flights.

None.

Exemptions include services less than $C 200$ in value. Foreign diplomatic staff are also exempt.

None.

None. accommodation and food.
Tickets are taxed at

15 percent of their value.

Tax is levied at the rate of 15 percent on the value of

Tax is levied at the rate of 15 percent on the cost of advertisement.

Tax is levied at the rate of 15 percent of:

(a) sums wagered at betting events;

(b) football pool prize money paid out;

(c) sums paid for sweepstake tickets. 


\section{Taxes on international trade}

6.1 Taxes on imports

\subsection{Customs duties}

Customs and Excise Decree, 1972

(N.R.C.D. 114); Customs and

Excise Tariff, 1973 (L.I. 838);

Customs and Excise Tariff

(Amendment) Regulations, 1976

(L.I. 1080); Customs and Excise

Tariff (Amendment) Regulations,

1977 (L.I. 1286); Customs and

Excise Tariff (Amendment) (No.2)

Regulations, 1983 (L.I. 1291);

Customs and Excise Tariff

(Amendment) Regulations 1984

(L.I. 1309); Budget 1985-96.
Duties are levied on most imported goods, generally as ad valorem taxes on the c.i.f. value, but for some goods the rates are specific.
Exemptions are granted for special purposes. Most imports of World Bank projects, the Volta Aluminum Company Ltd. (VALCO), Volta River Authority, diplomats, and certain welfare organizations are also exempt.

Items that are duty free are:

(a) agricultural machinery and tractors;

(b) bank notes and coins:

(c) crude oil;

(d) educational material;

(e) newsprint; and

(f) postage stamps.

Other exempted goods include:

(a) items imported for purpose of

exhibition at trade fairs;

(b) advertising materials;

(c) aircraft parts;

(d) passengers' baggage and effects.

not for resale;

(e) jute bags imported by

COCOBOD;

(f) agrochemicals; and

(g) foodstuff of West African origin.
Ghana maintains a column tariff, based on the Harmonized System. There are four ad valorem rates: 0 percent, 5 percent, 10 percent, and 25 percent. A special tax of 10 percent is applied to certain items such as textiles, alcoholic and nonalcoholic beverages, tobacco, etc. Motorcars including cross country cars of cylinder capacity in excess of 2,500 cc and vehicles designed for traveling on snow, golf carts, and similar vehicles attract a special tax of 17.5 percent.

\subsection{Export taxes}


Ghana: Summary of Tax System, May 1997

$\operatorname{Tax}$

6.21 Cocoa export duty

Customs and Excise Tariff, 1973

(L.I. 838); Excise Tariff

(Amendment) Regulations 1975

(L.I. 1024); and Customs and

Excise Tariff (Amendment)

Regulations, 1978

6.21 Cocoa export duty (continued)

(L.I. 1162). All laws under taxes on intemational trade have been consolidated into the Customs, Excise and Preventive Service (Management) Law, Part III; and Customs and Excise (duty rates and taxes) Law, 1991 (P.N.D.C. 262); Budget 1992-96.

7. Other taxes

\subsection{Stamp duties}

Stamp Act, 1965 (Act 3111); Stamp Act (Amendment) Decree, 1975 (N.R.C.D.

355); and Stamp Act 1980 (S.M.C.D. 424).

Ad valorem or specific rates of tax are levied on a range of legal documents and instruments, including bills of exchange, promissory notes, bills of lading, agreements, conveyances, extracts from registers, and mortgages.
Exemptions include instruments transferring ships, transactions where the Government would be liable for the stamp tax, and the transfer of company shares to a Ghanaian citizen.
Rates

The cocoa levy is a

100 percent duty on all proceeds received from cocoa exports after paying producers' costs and COCOBOD's marketing and other costs.

7.2 Other taxes, not elsewhere classified 
Ghana: Summary of Tax System, May 1997

Tax

Nature of $\operatorname{Tax}$

Exemptions and Deductions

Rates

7.21 Taxes on minerals and mining Minerals and Mining Law (P.N.D.C.L.

153); Selective Alien's Employment Tax Decree, 1973 (N.R.C.D. 201 248, and 268); Income Tax Decree, 1975 (S.M.C.D. 5); and Regulations 1986 (L.I. 1340)

7.21 Taxes on minerals and mining (continued)

7.22 Additional Profit Tax Law 1986 (P.N.D.C.L. 122).
The Minerals and Mining Law makes taxable any holder of a mining lease. Tax is also payable on the carry forward cash balance of an individual involved in mining operations. There are no tax holidays. Tax jurisdiction under S.M.C.D. 5 makes persons involved in the industry taxable on income accruing in, derived from, brought into, and received in Ghana for resident companies subject to deductions and exemptions noted.

An additional profit tax is chargeable on the carry forward cash balance of a year of assessment. The qualifying expenditure governing the determination of capital allowance under this law is deemed to have been incurred during January 1-

December 31, 1984 at a value to be determined by the Ministry of Finance and Economic Planning. The Secretary for Finance and Economic Planning has the responsibility for fixing the rate of return for the operation.
Exemptions include:

(a) exemption of staff from payment

of income tax relating to furnished accommodation at the mine site; (b) personal remittance quota for expatriate personnel free from any tax imposed by any enactment for the transfer of external currency out of Ghana; and

(c) exemption from the selective aliens employment tax under the Selective Alien Employment Tax Decree (N.R.C.D. 201).

None.

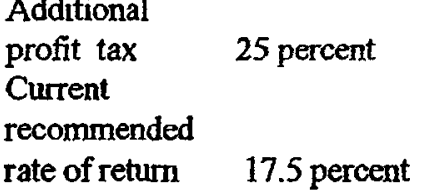
Rate of

royalty 3-12 percent; depending on profitability and certain operating costs.
Mining operations 35 percent 
Ghana: Summary of Tax System, May 1997

$\operatorname{Tax}$

7.23 Petroleum Income Tax Law 1987 (P.N.D.C.L. 188)
Nature of Tax

This law covers all persons carrying on petroleum operations, and is payable on income from the sale of petroleum less deductions.
Exemptions and Deductions

Deductions allowed:

(a) rent;

(b) interest paid on loans;

(c) repairs of premises used for the business;

(d) bad and doubtful debts;

(e) contributions to a pension find approved by the Commissionerwhere such contributions exceed 25 percent of the employees' remuneration, a 25 percent deduction is allowed; and

(f) losses incurred during a previous year of accounting, with the deduction being a sum equal to or less than the amount of such loss.
Rates

Petroleum companies:

35 percent unless a provision

is made in particular

petroleum agreement making alternative arrangements for paying the tax at a different rate, or another tax altogether.

\section{B. Local governments}

No details available.

Sources: International Bureau of Fiscal Documentation, African Tax Systems, and information provided by the Ghanaian authorities. 
Table 18. Ghana: Gross Domestic Product by Sector, 1993-97

\begin{tabular}{|c|c|c|c|c|c|}
\hline & 1993 & 1994 & 1995 & 1996 & 1997 \\
\hline & \multicolumn{5}{|c|}{ (In millions cedis at constant 1993 prices) } \\
\hline Agriculture & $1,430.0$ & $1,456.7$ & $1,511.2$ & $1,590.1$ & $1,658.4$ \\
\hline Agriculture and livestock & 994.0 & $1,003.0$ & $1,038.4$ & $1,103.5$ & $1,132.7$ \\
\hline Cocoa & 108.1 & 121.3 & 134.7 & 138.6 & 151.5 \\
\hline Forestry and logging & 107.7 & 109.6 & 111.8 & 114.8 & 139.5 \\
\hline Fishing & 220.2 & 222.8 & 226.3 & 233.2 & 234.7 \\
\hline Industrial & 961.1 & 994.5 & $1,035.3$ & $1,084.4$ & $1,153.3$ \\
\hline Mining and quarrying & 211.4 & 222.1 & 234.3 & 244.2 & 257.8 \\
\hline Manufacturing & 363.3 & 368.7 & 375.4 & 388.4 & 416.9 \\
\hline Electricity, water, and gas & 99.6 & 104.9 & 111.2 & 118.3 & 130.4 \\
\hline Construction & 286.8 & 298.8 & 314.4 & 333.5 & 348.2 \\
\hline Services & $1,065.8$ & $1,118.6$ & $1,170.8$ & $1,220.3$ & $1,300.2$ \\
\hline Transport, storage, and communications & 166.0 & 176.1 & 183.5 & 192.7 & 206.6 \\
\hline Wholesale and retail trade $1 /$ & 224.7 & 237.1 & 252.5 & 273.4 & 299.4 \\
\hline Finance, real estate, and business services & 158.8 & 165.2 & 170.1 & 177.3 & 189.2 \\
\hline Public administration defense and other services & 409.5 & 430.4 & 451.9 & 462.6 & 482.4 \\
\hline Community, social and personal services & 70.8 & 72.9 & 74.8 & 75.6 & 81.1 \\
\hline Producer of private non-profit services & 36.0 & 36.9 & 38.0 & 38.7 & 41.5 \\
\hline Net Indirect Taxes & 415.6 & 429.3 & 442.7 & 456.4 & 422.0 \\
\hline \multirow[t]{2}{*}{ Gross domestic product } & $3,872.5$ & $3,999,1$ & $4,160.0$ & $4,351.2$ & $4,533.9$ \\
\hline & \multicolumn{5}{|c|}{ (In billions of cedis at current market prices) } \\
\hline Agriculture & $1,430.0$ & $1,971.2$ & $3,006.0$ & $4,417.0$ & $5,050.1$ \\
\hline Agriculture and livestook & 994.0 & $1,307.0$ & $1,827.0$ & $2,750.0$ & $3,192.6$ \\
\hline Cocon & 108.1 & 235.2 & 524.0 & 690.0 & 656.1 \\
\hline Forestry and logging & 107.7 & 139.0 & 211.0 & 297.0 & 477.2 \\
\hline Fishing & 220.2 & 290.0 & 444.0 & 680.0 & 724.2 \\
\hline Industrial & 961.1 & $1,294.0$ & $1,882.0$ & $2,673.0$ & $3,622.6$ \\
\hline Mining and quarrying & 211.4 & 293.0 & 371.0 & 536.0 & 719.8 \\
\hline Manufacturing & 363.3 & 472.0 & 723.0 & 979.0 & $1,277.5$ \\
\hline Electricity, water, and gas & 99.6 & 139.0 & 206.0 & 302.0 & 425.7 \\
\hline Construction & 286.8 & 390.0 & 582.0 & 856.0 & $1,199.6$ \\
\hline Services & $1,065.8$ & $1,420.8$ & $2,152.6$ & $2,977.0$ & $3,935.8$ \\
\hline Transport, storage, and communications & 166.0 & 224.0 & 303.0 & 423.0 & 580.4 \\
\hline Wholesale and retail trade & 224.7 & 297.8 & 465.0 & 654.0 & 917.0 \\
\hline Finance, real estate, and business services & 158.8 & 209.0 & 302.6 & 430.0 & 586.6 \\
\hline Public administration defense and other services & 409.5 & 540.0 & 825.0 & $1,124.0$ & $1,377.0$ \\
\hline Community, social and personal services & 70.8 & 103.0 & 185.0 & 249.0 & 341.6 \\
\hline Producers of private non-profit services & 36.0 & 47.0 & 72.0 & 97.0 & 133.2 \\
\hline Net indirect taxes & 415.6 & $\$ 19.0$ & 712.0 & $1,272.0$ & $1,504.9$ \\
\hline \multirow[t]{2}{*}{ Gross domestic product } & $3,872.5$ & $5,205.0$ & $7,752.6$ & $11,339.0$ & $14,113.4$ \\
\hline & \multicolumn{5}{|c|}{ (Annual percentage of change) } \\
\hline \multicolumn{6}{|l|}{ Memorandum items : } \\
\hline GDP deflator & ... & 30.2 & 43.2 & 39.8 & 19.5 \\
\hline GDP at current market prices & $\ldots$ & 34.4 & 49.0 & 46.3 & 24.5 \\
\hline GDP at constant 1993 prices & $\ldots$ & 3.3 & 4.0 & 4.6 & 4.2 \\
\hline Per capita real GDP & $\ldots$ & 0.1 & 0.9 & 1.4 & 1.2 \\
\hline
\end{tabular}

Sources: Statistical Service; and staff estimates.

1/ Revised estimates.

2/ Estimates.

3/ Including restaurants and hotels. 
Table 19. Ghana: Gross Domestic Product by Expenditure Category, 1993-97

\begin{tabular}{|c|c|c|c|c|c|}
\hline & 1993 & 1994 & 1995 & 1996 & 1997 \\
\hline & \multicolumn{5}{|c|}{ (In million of cedis at constant 1993 prices) } \\
\hline Consumption & $3,616.9$ & $3,542.0$ & $3,686.2$ & $3,704.5$ & $4,082.2$ \\
\hline Government & 568.2 & 583.1 & 588.2 & 593.6 & 592.5 \\
\hline Private sector & $3,048.7$ & $2,958.9$ & $3,098.0$ & $3,110.9$ & $3,489.7$ \\
\hline Total investment & 860.6 & $1,027.1$ & 940.8 & $1,078.6$ & $1,115.3$ \\
\hline Gross fixed capital formation & 921.3 & 965.8 & $1,002.7$ & $1,016.1$ & $1,054.5$ \\
\hline Inventories & -60.7 & 61.3 & -61.9 & 62.5 & 60.8 \\
\hline Foreign balance & -604.7 & -570.0 & -467.0 & -431.9 & -663.6 \\
\hline Exports of goods and non factor services & 693.3 & 729.8 & 908.4 & $1,120.6$ & $1,115.7$ \\
\hline Imports of goods and non factor services & $-1,298.0$ & $-1,299.8$ & $-1,375.4$ & $-1,552.5$ & $-1,779.3$ \\
\hline Gross domestic expenditure & $5,775.5$ & $5,868.9$ & $6,002.4$ & $6,335.6$ & $6,976.8$ \\
\hline \multirow[t]{2}{*}{ Gross domestic product } & $3,872.8$ & $3,999.1$ & $4,160.0$ & $4,351.2$ & $4,533.9$ \\
\hline & \multicolumn{5}{|c|}{ (In billion of cedis at current market prices) } \\
\hline Consumption & $3,616.9$ & $4,548.8$ & $6,845.8$ & $9,994.6$ & $12,726.5$ \\
\hline Government & 568.2 & 714.3 & 935.9 & $1,365.6$ & $1,743.8$ \\
\hline Private sector & $3,048.7$ & $3,837.9$ & $5,909.9$ & $8,629.0$ & $10,982.7$ \\
\hline Total investment & 860.6 & $1,246.7$ & $1,552.1$ & $2,434.2$ & $3,405.5$ \\
\hline Gross fixed capital formation & 921.3 & $1,174.5$ & $1,638.0$ & $2,332.0$ & $3,278.2$ \\
\hline Inventories & -60.7 & 72.2 & -85.9 & 102.2 & 127.3 \\
\hline Foreign balance & -604.7 & -590.7 & -645.3 & $-1,089.6$ & $-2,018.6$ \\
\hline Exports of goods and non factor services & 693.3 & $1,171.5$ & $1,898.9$ & $2,827.3$ & $3,393.9$ \\
\hline Imports of goods and non factor services & $-1,298.0$ & $-1,762.2$ & $-2,544.2$ & $-3,916.9$ & $-5,412.5$ \\
\hline Gross domestic expenditure & $5,775.5$ & $5,868.9$ & $6,002.4$ & $6,335.6$ & $6,976.8$ \\
\hline Gross domestic product & $3,872.8$ & $5,204.8$ & $7,752.6$ & $11,339.2$ & $14,113.4$ \\
\hline
\end{tabular}

Sources: Ghana Statistical Service. 
Table 20. Ghana: Composition and Growth of Gross Domestic Product by Sector, 1993-97

\begin{tabular}{|c|c|c|c|c|c|}
\hline & 1993 & 1994 & 1995 & $\begin{array}{l}1996 \\
\text { Prov. }\end{array}$ & $\begin{array}{l}1997 \\
\text { Prov. }\end{array}$ \\
\hline & \multicolumn{5}{|c|}{ (In percent of nominal GDP) } \\
\hline Agriculture & 36.9 & 36.4 & 36.3 & 36.6 & 36.6 \\
\hline Agriculture and livestock & 25.7 & 25.1 & 25.0 & 25.4 & 25.0 \\
\hline Cocoa & 2.8 & 3.0 & 3.2 & 3.2 & 3.3 \\
\hline Forestry and logging & 2.7 & 2.7 & 2.7 & 2.6 & 3.1 \\
\hline Fishing & 5.7 & 5.6 & 5.4 & 5.4 & 5.2 \\
\hline Industrial & 24.9 & 24.9 & 24.9 & 24.9 & 25.5 \\
\hline Mining and quarrying & 5.5 & 5.6 & 5.6 & 5.6 & 5.7 \\
\hline Manufacturing & 9.4 & 9.2 & 9.0 & 8.9 & 9.2 \\
\hline Electricity, water, and gas & 2.6 & 2.6 & 2.7 & 2.7 & 2.9 \\
\hline Construction & 7.4 & 7.5 & 7.6 & 7.7 & 7.7 \\
\hline Services & 27.5 & 28.0 & 28.2 & 28.0 & 28.6 \\
\hline Transport, storage, and communication & 4.3 & 4.5 & 4.4 & 4.4 & 4.5 \\
\hline Wholesale and retail trade $1 /$ & 5.8 & 5.9 & 6.1 & 6.3 & 6.6 \\
\hline Finance, real estate, and business services & 4.1 & 4.1 & 4.1 & 4.1 & 4.2 \\
\hline Public administration defense and other services & 10.6 & 10.8 & 10.9 & 10.6 & 10.6 \\
\hline Community, social and personal services & 1.8 & 1.8 & 1.8 & 1.7 & 1.8 \\
\hline Producers of private non-profit services & 0.9 & 0.9 & 0.9 & 0.9 & 0.9 \\
\hline Net indirect taxes & 10.7 & 10.7 & 10.6 & 10.5 & 9.3 \\
\hline \multirow[t]{2}{*}{ Gross domestic product } & 100.0 & 100.0 & 100.0 & 100.0 & 100.0 \\
\hline & \multicolumn{5}{|c|}{ (Annual percentage changes in 1993 constant prices) } \\
\hline Agriculture & $\ldots$ & 16.1 & 18.1 & 14.9 & 34.0 \\
\hline Agriculture and livestock & $\ldots$ & 0.9 & 3.5 & 6.3 & 2.6 \\
\hline Cocoa & $\ldots$ & 12.2 & 11.0 & 2.9 & 9.3 \\
\hline Forestry and logging & $\ldots$ & 1.8 & 2.0 & 2.7 & 21.5 \\
\hline Fishing & $\ldots$ & 1.2 & 1.6 & 3.0 & 0.6 \\
\hline Industrial & $\ldots$ & 16.1 & 18.5 & 20.2 & 27.5 \\
\hline Mining and quarrying & $\ldots$ & 5.1 & 5.5 & 4.2 & 5.6 \\
\hline Manufacturing & $\ldots$ & 1.5 & 1.8 & 3.5 & 7.3 \\
\hline Electricity, water, and gas & $\ldots$ & 5.3 & 6.0 & 6.4 & 10.2 \\
\hline Construction & $\ldots$ & 4.2 & 5.2 & 6.1 & 4.4 \\
\hline Services & $\ldots$ & 26.2 & 24.3 & 22.8 & 42.2 \\
\hline Transport, storage, and communication & $\ldots$ & 6.1 & 4.2 & 5.0 & 7.2 \\
\hline Wholesale and retail trade $1 /$ & $\ldots$ & 5.5 & 6.5 & 8.3 & 9.5 \\
\hline Finance, real estate, and business services & $\ldots$ & 4.0 & 3.0 & 4.2 & 6.7 \\
\hline Public administration defense and other services & $\ldots$ & 5.1 & 5.0 & 2.4 & 4.3 \\
\hline Community, social and personal services & $\ldots$ & 3.0 & 2.6 & 1.1 & 7.3 \\
\hline Producers of private non-profit services & $\ldots$ & 2.5 & 3.0 & 1.8 & 7.2 \\
\hline Net indirect taxes & $\ldots$ & 3.3 & 3.1 & 3.1 & -7.5 \\
\hline Gross domestic product & $\ldots$ & 3.3 & 4.0 & 4.6 & 4.2 \\
\hline
\end{tabular}

Sources: Ghana Statistical Service.

1/ Including restaurants and hotels. 
Table 21. Ghana: Composition and Growth of Gross Domesitc Product by Expenditure Category, 1993-97

\begin{tabular}{|c|c|c|c|c|c|}
\hline & 1993 & 1994 & 1995 & 1996 & 1997 \\
\hline & \multicolumn{5}{|c|}{ (In percent of nominal GDP) } \\
\hline Consumption & 93.4 & 87.4 & 88.3 & 88.1 & 90.2 \\
\hline Government & 14.7 & 13.7 & 12.1 & 12.0 & 12.4 \\
\hline Private sector & 78.7 & 73.7 & 76.2 & 76.1 & 77.8 \\
\hline Total investment & 22.2 & 24.0 & 20.0 & 21.5 & 24.1 \\
\hline Gross fixed capaital formation & 23.8 & 22.6 & 21.1 & 20.6 & 23.2 \\
\hline Inventories & -1.6 & 1.4 & -1.1 & 0.9 & 0.9 \\
\hline Foreign balance & -15.6 & -11.4 & -8.3 & -9.6 & -14.3 \\
\hline Exports of goods and nonfactor services & 17.9 & 22.5 & 24.5 & 24.9 & 24.0 \\
\hline Imports of goods and nonfactor services & -33.5 & -33.9 & -32.8 & -34.5 & -38.3 \\
\hline Gross domestic expenditure & 149.1 & 145.2 & 141.1 & 144.2 & 152.7 \\
\hline \multirow[t]{2}{*}{ Gross domestic product } & 100.0 & 100.0 & 100.0 & 100.0 & 100.0 \\
\hline & \multicolumn{5}{|c|}{ (Annual percentage changes in constant 1993 prices) } \\
\hline Consumption & $\ldots$ & -2.1 & 4.1 & 0.5 & 10.2 \\
\hline Government & $\ldots$ & 2.6 & 0.9 & 0.9 & -0.2 \\
\hline Private sector & $\ldots$ & -2.9 & 4.7 & 0.4 & 12.2 \\
\hline Total investment & $\ldots$ & 19.3 & -8.4 & 14.6 & 3.4 \\
\hline Gross fixed capital formation & $\ldots$ & 4.8 & 3.8 & 1.3 & 3.8 \\
\hline Inventories & $\ldots$ & -201.0 & -201.0 & -201.0 & -2.7 \\
\hline Foreign balance & $\ldots$ & & & & \\
\hline Exports of goods and nonfactor services & $\ldots$ & 0.9 & 2.5 & 0.8 & -5.1 \\
\hline Imports of goods and nonfactor services & $\ldots$ & 5.9 & 12.3 & 24.1 & -1.3 \\
\hline Gross domestic expenditure & $\ldots$ & 3.3 & 4.0 & 4.6 & 4.2 \\
\hline Gross domestic prodúct & $\ldots$ & 3.3 & 4.0 & 4.6 & 4.2 \\
\hline
\end{tabular}

Sources: Statistical Service; and staff estimates.

1/ Total investment expenditure published by the GSS is smaller than the staff's estimate; it differs by the amount of government domestic investment expendiutre on commitment basis and by the estimate of foreign financed investment expenditure. 
Table 22. Ghana: Saving and Investment, 1993-1997

\begin{tabular}{|c|c|c|c|c|c|}
\hline & 1993 & 1994 & 1995 & 1996 & 1997 \\
\hline & \multicolumn{5}{|c|}{ (In billions of cedis at current market prices) } \\
\hline National income & $3,470.6$ & $4,688.0$ & $7,083.6$ & $10,318.4$ & $12,847.7$ \\
\hline Net transfer from abroad & 335.8 & 451.4 & 628.0 & 788.6 & $1,180.0$ \\
\hline National disposable income & $3,806.4$ & $5,139.4$ & $7,711.6$ & $11,107.0$ & $14,027.7$ \\
\hline Total consumption & $3,616.9$ & $4,548.8$ & $6,845.8$ & $9,994.6$ & $12,726.5$ \\
\hline Net saving & 189.5 & 587.2 & 865.8 & $1,112.4$ & $1,301.2$ \\
\hline Net capital formation & 531.6 & 835.5 & $1,037.8$ & $1,633.7$ & $2,408.8$ \\
\hline Consumption of fixed captial & 329.0 & 411.2 & 514.0 & 800.8 & 996.7 \\
\hline Gross capital formation & 860.6 & $1,246.7$ & $1,551.8$ & $2,434.5$ & $3,405.5$ \\
\hline Buildings & 461.3 & 563.3 & 832.1 & $1,092.0$ & $1,445.2$ \\
\hline Other construction work & 64.1 & 92.6 & 143.2 & 235.2 & 385.6 \\
\hline Land improvements and plantations & 0.7 & 1.3 & 1.6 & 2.2 & 3.5 \\
\hline Transport equipment & 168.4 & 210.8 & 271.5 & $401: 8$ & 602.2 \\
\hline Machinery and equipment & 226.8 & 306.5 & 389.3 & 601.1 & 868.7 \\
\hline Change in stocks & -60.7 & 72.2 & -85.9 & 102.2 & 127.3 \\
\hline External current account balance & 362.7 & -248.3 & 172.4 & 530.0 & $1,109.0$ \\
\hline \multirow[t]{2}{*}{ GDP } & $3,872.5$ & $5,204.8$ & $7,752.6$ & $11,339.2$ & $14,113.4$ \\
\hline & \multicolumn{5}{|c|}{ (In percent of nominal GDP) } \\
\hline National disposable income & 98.3 & 98.7 & 99.5 & 98.0 & 99.4 \\
\hline Total consumption & 93.4 & 87.5 & 88.3 & 88.1 & 90.2 \\
\hline Net saving & 4.9 & 11.3 & 11.2 & 9.8 & 9.2 \\
\hline Net capital formation & 13.7 & 16.1 & 13.4 & 14.4 & 17.1 \\
\hline Gross capital formation & 22.2 & 24.0 & 20.0 & 21.5 & 24.1 \\
\hline External current account balance & 9.4 & 4.7 & 2.2 & 4.7 & 7.9 \\
\hline
\end{tabular}

Sources: Ghana Statistical Service. 
Table 23. Ghana: Cocoa Bean Production, Consumption, Prices, Payments to Farmers, and Export Receipts, 1985/86-1997/98

\begin{tabular}{|c|c|c|c|c|c|c|c|c|}
\hline \multirow[b]{2}{*}{ Oct. 1-Sept. 30} & \multicolumn{3}{|c|}{ Production } & \multicolumn{2}{|c|}{ Consumption } & \multirow{2}{*}{$\begin{array}{r}\text { Producer } \\
\text { Price 2l }\end{array}$} & \multirow{2}{*}{$\begin{array}{r}\text { Payments } \\
\text { to cocoa } \\
\text { farmers }\end{array}$} & \multirow{2}{*}{$\begin{array}{l}\text { Export } \\
\text { receipts } \\
\text { (beans) }\end{array}$} \\
\hline & Main Crop & Midcrop & Total & Domestic 1/ & Export & & & \\
\hline & \multicolumn{5}{|c|}{ (Thousands of metric tons) } & $\begin{array}{l}\text { (Cedis per } \\
\text { metric ton) }\end{array}$ & \multicolumn{2}{|c|}{ (In millions of cedis) } \\
\hline 1985/86 & 205 & 14 & 219 & 25 & 193 & $\begin{array}{l}56,6003 / \\
85,500 \quad 4 /\end{array}$ & 12,786 & 40,225 \\
\hline $1986 / 87$ & 218 & 9 & 227 & 22 & 205 & $\begin{array}{rl}85,500 & 3 / \\
150,000 & 4 /\end{array}$ & 21,590 & 52,869 \\
\hline $1987 / 88$ & 173 & 15 & 188 & 20 & 168 & $\begin{array}{ll}150,000 & 3 / \\
165,000 & 4 /\end{array}$ & 32,149 & 66,600 \\
\hline 1988/89 & 290 & 15 & 300 & 20 & 281 & $\begin{array}{ll}165,000 & 3 / \\
174,400 & 4 /\end{array}$ & 49,594 & 115,717 \\
\hline 1989/90 & 282 & 13 & 295 & 20 & 275 & $\begin{array}{ll}174,400 & 3 / \\
224,000 & 4 /\end{array}$ & 52,000 & 105,000 \\
\hline 1990/91 & 261 & 32 & 293 & 20 & 242 & $\begin{array}{ll}224,000 & 3 / \\
251,200 & 4 /\end{array}$ & 66,502 & 117,962 \\
\hline 1991/92 & 229 & 13 & 242 & 23 & 254 & $\begin{array}{ll}251,200 & 3 / \\
258,000 & 4 /\end{array}$ & 60,879 & 131,089 \\
\hline 1992/93 & 262 & 49 & 311 & 30 & 281 & $\begin{array}{ll}258,000 & 3 / \\
308,000 & 4 /\end{array}$ & 67,915 & 137,866 \\
\hline 1993/94 & 220 & 20 & 240 & 40 & 200 & $\begin{array}{l}308,000 \quad 3 / \\
700,000 \quad 4 /\end{array}$ & 86,784 & 243,805 \\
\hline $1994 / 95$ & 260 & 30 & 290 & 30 & 260 & $\begin{array}{r}700,000 \quad 3 / \\
\ldots \quad 4 l\end{array}$ & 205,500 & 381,360 \\
\hline $1995 / 96$ & 349 & 54 & 403 & 58 & 345 & $\begin{array}{r}840,000 \quad 3 / \\
1,200,000 \quad 4 /\end{array}$ & 372,666 & 693,605 \\
\hline 1996/97 & 295 & 25 & 320 & 60 & 260 & $\begin{array}{ll}1,200,000 & 3 / \\
1,800,000 & 4 /\end{array}$ & 399,963 & 709,200 \\
\hline $1997 / 98$ & 360 & 30 & 390 & 60 & 330 & $\begin{array}{l}1,800,0003 / \\
2,250,0004 /\end{array}$ & 711,000 & $1,109,434$ \\
\hline
\end{tabular}


Table 24. Ghana: Operations of the Cocoa Board, 1990/91-1997/98

\begin{tabular}{|c|c|c|c|c|c|c|c|c|}
\hline & $1990 / 91$ & $1991 / 92$ & $1992 / 93$ & $1993 / 94$ & $1994 / 95$ & $\frac{1995 / 96}{\text { Acrual }}$ & $\frac{1996 / 97}{\text { Actual }}$ & $\frac{1997 / 98}{\text { Budget }}$ \\
\hline & & \multicolumn{7}{|c|}{ (In millions of cedis) } \\
\hline Revenue & 134,560 & 141,983 & 168,302 & 267,240 & 460,432 & 793,990 & 873,325 & $1,396,265$ \\
\hline Exports & 119,522 & 126,450 & 137,866 & 243,805 & 381,360 & 693,605 & 709,200 & $1,109,734$ \\
\hline Local deliveries & 13,938 & 15,223 & 19,220 & 16,347 & 72,072 & 73,836 & 136,831 & 233,206 \\
\hline Miscellaneous & 206 & 310 & 11,216 & 7,088 & 7,000 & 26,549 & 27,294 & 53,325 \\
\hline Other & 894 & 0.0 & 0.0 & 0.0 & 0.0 & 0.0 & 0.0 & 0.0 \\
\hline Costs & 105,600 & 109,848 & 138,034 & 147,451 & 306,410 & 523,990 & 607,393 & $1,006,062$ \\
\hline Producer proceeds & 64,714 & 62,034 & 67,915 & 86,784 & 205,500 & 372,666 & 399,963 & 711,000 \\
\hline Licensed buying agents & 13,871 & 14,661 & -- & 15,116 & 32,580 & 86,475 & 88,400 & 125,463 \\
\hline Freight & 2,406 & 1,857 & -- & 16,862 & 31,238 & 16,984 & 28,896 & 36,660 \\
\hline Finance costs $2 /$ & 9,892 & 8,576 & 19,449 & 5,060 & 7,402 & 16,157 & 21,311 & 29,115 \\
\hline Administration $3 /$ & 3,800 & 11,406 & 4,661 & 4,108 & 3,523 & 13,138 & 6,457 & 7,104 \\
\hline Other $4 /$ & 10,917 & 11,314 & 46,009 & 19,521 & 26,167 & 18,570 & 62,366 & 96,720 \\
\hline \multicolumn{9}{|l|}{ Profits/Losses (-) } \\
\hline before taxes & 28,960 & 32,135 & 30,268 & 119,789 & 154,022 & 270,000 & 265,932 & 390,203 \\
\hline Duties paid & 31,552 & 20,610 & 36,703 & 122,999 & 154,022 & 270,000 & 265,932 & 390,203 \\
\hline \multicolumn{9}{|l|}{ Profits/Losses (-) } \\
\hline & \multicolumn{8}{|c|}{ (In thousands of metric tons) } \\
\hline Memorandum items: & & & & & & & & \\
\hline Purchases & 287.9 & 247.0 & 312.0 & 255.0 & 309.0 & 403.8 & 323.0 & 390.0 \\
\hline Shipments & 262.0 & 277.0 & 301.0 & 240.0 & 290.0 & 403.8 & 323.0 & 390.0 \\
\hline \multicolumn{9}{|l|}{ Of which: } \\
\hline Exports & 242.0 & 254.0 & $281.0^{-}$ & 200.0 & 260.0 & 345.4 & 260.0 & 330.0 \\
\hline \multirow[t]{2}{*}{ Local deliveries } & 20.0 & 23.0 & 20.0 & 40.0 & 30.0 & 58.4 & 60.0 & 60.0 \\
\hline & \multicolumn{8}{|c|}{ (In cedis per metric ton) } \\
\hline Value of exports & 493,893 & 497,835 & 490,626 & $1,219,025$ & $1,466,769$ & $2,008,121$ & $2,727,692$ & $3,362,830$ \\
\hline $\begin{array}{l}\text { Value of local } \\
\text { deliveries }\end{array}$ & 696,900 & 661,870 & 961,000 & 408,675 & $2,402,400$ & $1,264,315$ & $2,280,517$ & $3,886,767$ \\
\hline Average price received & 509,389 & 511,455 & 521,880 & $1,083,967$ & $1,563,559$ & $1,900,547$ & $2,619,291$ & $3,443,436$ \\
\hline Producer proceeds & 224,779 & 251,150 & 217,676 & 340,329 & 665,049 & 922,897 & $1,238,276$ & $1,823,077$ \\
\hline Total costs & 366,794 & 444,729 & 442,417 & 578,239 & 991,618 & $1,297,647$ & $1,880,474$ & $2,579,646$ \\
\hline Duties paid & 109,594 & 83,441 & 117,638 & 482,349 & 498,453 & 668,648 & 823,319 & $1,000,521$ \\
\hline
\end{tabular}

Source: Cocoa Board.

1/ Crop year ending September 30.

2/ Mainly discount charges on bills drawn to finance the purchases of cocoa, export duty, and operations of the Cocoa Board

3/ Includes provision for doubtful debts and depreciation. Includes all other Cocoa Board costs in 1992/93.

4/ Includes outlays for produce inspection, research, construction of feeder roads, and subsidies for insecticides and spraying. Includes a provision of 8.5 billion cedis for retrenchment in 1993/94. 
Table 25. Ghana: Production, Acreage, and Yield of Principal Food Crops, 1991-97

\begin{tabular}{|c|c|c|c|c|c|c|c|}
\hline & 1991 & 1992 & 1993 & 1994 & 1995 & 1996 & 1997 \\
\hline & \multicolumn{7}{|c|}{ (In thousands of metric tons) } \\
\hline \multicolumn{8}{|l|}{ Production } \\
\hline Cassava & 5,702 & 5,662 & 5,972 & 6,025 & 6,611 & 7,111 & 7,150 \\
\hline Plantain & 1,178 & 1,082 & 1,322 & 1,475 & 1,636 & 1,823 & 1,878 \\
\hline Cocoyams & 1,297 & 1,202 & 1,236 & 1,148 & 1,383 & 1,552 & 1,535 \\
\hline Yams & 2,632 & 2,331 & 2,720 & 1,700 & 2,126 & 2,275 & 2,417 \\
\hline Maize & 932 & 731 & 961 & 939 & 1,034 & 1,008 & 1,021 \\
\hline Guinea corn & 241 & 259 & 328 & 394 & 360 & 353 & 320 \\
\hline Millet & 112 & 133 & 198 & 168 & 209 & 193 & 139 \\
\hline Rice & 151 & 132 & 157 & 162 & 221 & 216 & 197 \\
\hline & \multicolumn{7}{|c|}{ (In thousands of hectares) } \\
\hline \multicolumn{8}{|l|}{ Acreage } \\
\hline Cassava & 535 & 552 & 532 & 520 & 551 & 591 & 593 \\
\hline Plantain & 174 & 157 & 164 & 165 & 213 & 227 & 223 \\
\hline Cocoyams & 203 & 196 & 173 & 191 & 203 & 214 & 205 \\
\hline Yams & 227 & 224 & 207 & 219 & 176 & 178 & 187 \\
\hline Maize & 610 & 607 & 637 & 618 & 569 & 665 & 663 \\
\hline Guinea corn & 263 & 307 & 309 & 293 & 335 & 314 & 317 \\
\hline Millet & 209 & 210 & 204 & 208 & 193 & 150 & 187 \\
\hline Rice & 95 & 80 & 77 & 84 & 100 & 105 & 109 \\
\hline & \multicolumn{7}{|c|}{ (In metric tons per hectare) } \\
\hline \multicolumn{8}{|l|}{ Yield } \\
\hline Cassava & 10.7 & 10.3 & 11.2 & 11.6 & 12.0 & 12.0 & 12.1 \\
\hline Plantain & 6.8 & 6.9 & 8.1 & 6.0 & 7.7 & 8.0 & 8.4 \\
\hline Cocoyams & 6.4 & 6.1 & 7.1 & 6.4 & 6.8 & 7.3 & 7.5 \\
\hline Yams & 11.6 & 10.4 & 13.1 & 11.0 & 12.1 & 12.8 & 12.9 \\
\hline Maize & 1.5 & 1.2 & 1.5 & 1.5 & 1.6 & 1.5 & 1.5 \\
\hline Guinea corn & 0.9 & 0.8 & 1.1 & 1.1 & 1.1 & 1.1 & 1.0 \\
\hline Millet & 0.5 & 0.6 & 1.0 & 0.9 & 1.1 & 1.0 & 0.7 \\
\hline Rice & 1.6 & 1.7 & 2.0 & 2.0 & 2.2 & 2.1 & 1.8 \\
\hline
\end{tabular}

Source: Statistical Service, Quarterly Digest of Statistics 
Table 26. Ghana: Production and Exports of Logs, Sawn Timber, Veneer, and Plywood, 1991-97

\begin{tabular}{|c|c|c|c|c|c|c|c|}
\hline & 1991 & 1992 & 1993 & 1994 & 1995 & 1996 & 1997 \\
\hline & \multicolumn{7}{|c|}{ (In thousands of cubic meters) } \\
\hline Logs & 1,229 & 1,318 & 1,682 & 1,681 & 1,194 & 1,166 & 1,170 \\
\hline Exports & 215 & 161 & 496 & 572 & 80 & 2 & 0.4 \\
\hline Sawmill intake & 924 & 916 & 980 & 1026 & 959 & 947 & 969 \\
\hline Veneer/plywood intake & 46 & 54 & 63 & 78 & 97 & 190 & 193 \\
\hline $\begin{array}{l}\text { Unrecorded uses and } \\
\text { changes in stocks }\end{array}$ & 44 & 187 & 143 & 5 & 58 & 27 & 8 \\
\hline Sawn timber & 578 & 549 & 600 & 530 & 580 & 618 & 740 \\
\hline Exports & 183 & 232 & 238 & 259 & 286 & 239 & 279 \\
\hline Local sales & 202 & 200 & 333 & 249 & 270 & 349 & 424 \\
\hline Own use & - & -- & $\ldots$ & $\ldots$ & $\ldots$ & $\ldots$ & \\
\hline $\begin{array}{l}\text { Unrecorded uses and } \\
\text { changes in stocks }\end{array}$ & 193 & 117 & 29 & 22 & 24 & 30 & 37 \\
\hline Veneer & 23 & 26 & 30 & 40 & 51 & 61 & 73 \\
\hline Exports & 20 & 23 & 25 & 35 & 45 & 54 & 65 \\
\hline Local sales & 2 & 2 & 3 & 3 & 4 & 4 & 5 \\
\hline Own use & 1 & 1 & 2 & 2 & 2 & 3 & 3 \\
\hline Changes in stocks & $\ldots$ & $\ldots$ & $\cdots$ & $\ldots$ & $\ldots$ & $\cdots$ & \\
\hline Plywood & 2 & 3 & 3 & 2 & 6 & 37 & 48 \\
\hline Exports & 1 & 2 & 2 & 1 & 4 & 20 & 26 \\
\hline Local sales & 1 & 1 & 1 & 1 & 1 & 14 & 18 \\
\hline Changes in stocks & $\ldots$ & $\ldots$ & $\ldots$ & 0 & 1 & 3 & 4 \\
\hline
\end{tabular}

Sources: Statistical Service; and Ministry of Lands and Natural Resources. 
Table 27. Ghana: Domestic Fish Catch and Imports, 1991-96

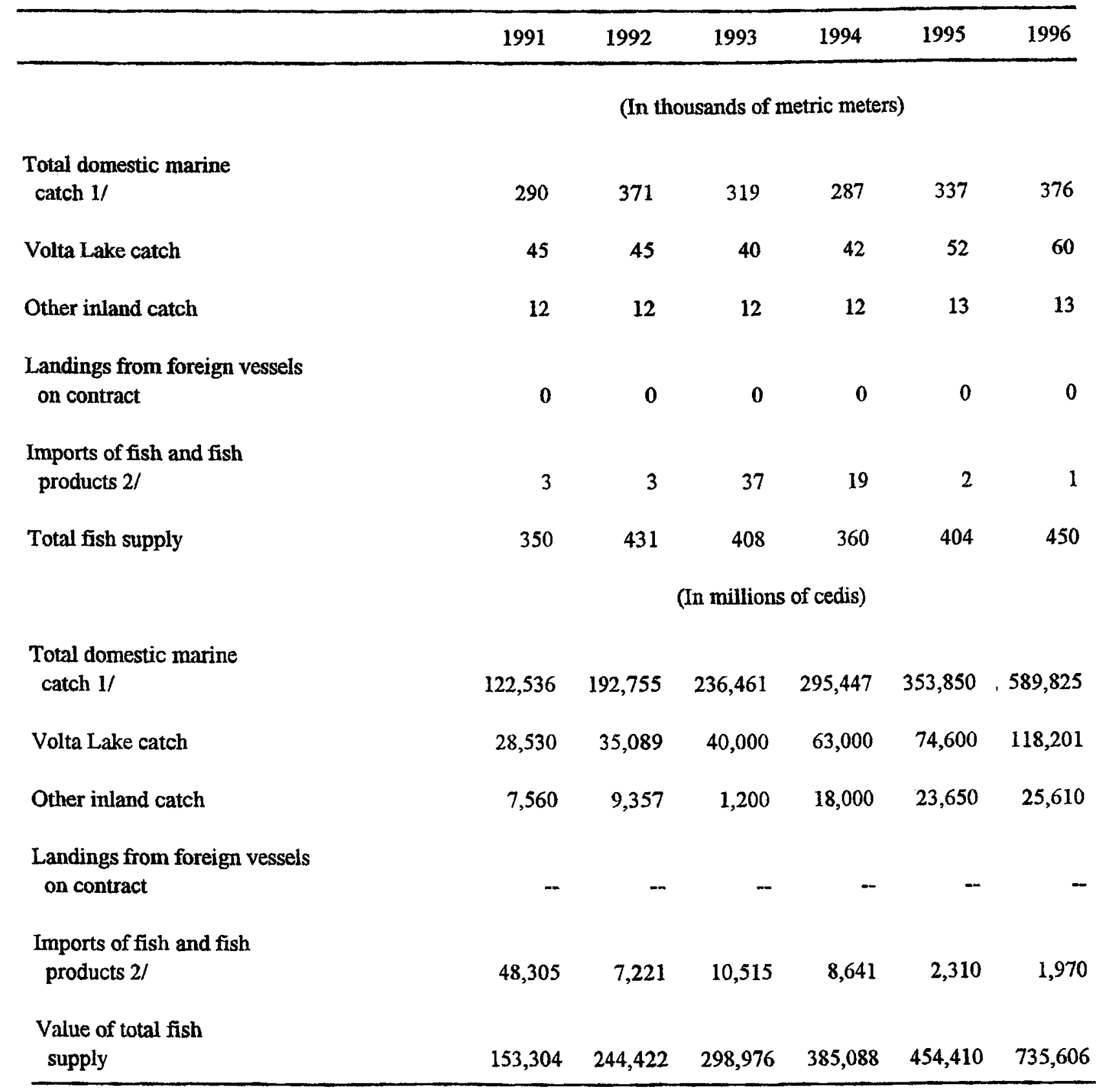

Source: Ministry of Agriculture.

1/ Excluding fish caught by foreign vessels.

2/ Mostly frozen fish. 
Table 28. Ghana: Mineral Production, 1991-97

\begin{tabular}{|c|c|c|c|c|c|c|c|}
\hline & 1991 & 1992 & 1993 & 1994 & 1995 & $19961 /$ & 19971 \\
\hline Value of output & \multicolumn{7}{|c|}{ (In millions of cedis) } \\
\hline Gold & $76,865.4$ & $205,786.3$ & $265,606.6$ & $359,173.5$ & $765,755.1$ & $970,588.5$ & $1,152,464.9$ \\
\hline Diamonds & $4,658.3$ & $8,498.0$ & $9,404.0$ & $19,350.6$ & $15,344.0$ & $23,696.9$ & $24,570.0$ \\
\hline Manganese & $9,333.5$ & $12,811.0$ & $10,185.1$ & $10,720.3$ & $8,076.1$ & $10,463.1$ & $21,820.3$ \\
\hline Bauxite & $6,050.2$ & $9,000.5$ & $8,968.7$ & $8,653.2$ & $12,605.4$ & $13,693.9$ & $20,654.4$ \\
\hline Volume & \multicolumn{7}{|c|}{ (In units specified) } \\
\hline Gold ('000 kg) & 26.1 & 31.4 & 38.6 & 43.3 & 51.3 & 48.3 & 53.5 \\
\hline Diamonds ('000 carats) & 419.4 & 584.5 & 616.0 & 426.1 & 622.7 & 714.3 & 585.5 \\
\hline Manganese ('000 metric tons) & 415.2 & 477.7 & 361.7 & 269.7 & 100.0 & 266.8 & 333.4 \\
\hline Bauxite ('000 metric tons) & 485.1 & 498.1 & 482.5 & 426.1 & 513.0 & 383.4 & 500.7 \\
\hline Unit values & \multicolumn{7}{|c|}{ (In cedis per unit) } \\
\hline Gold (gram) & 5,388 & 6,554 & 6,881 & 8,295 & 14,927 & 20,095 & 21,541 \\
\hline Diamonds (carat) & 11,107 & 14,539 & 15,266 & 26,768 & 24,641 & 33,175 & 39,944 \\
\hline Manganese (metric ton) & 22,477 & 26,818 & 28,159 & 39,749 & 11,867 & 39,217 & 65,447 \\
\hline Bauxite (metric ton) & 12,472 & 17,655 & 18,588 & 20,308 & 24,572 & 35,717 & 41,251 \\
\hline
\end{tabular}

Sources: Statistical Service; and staff estimates.

1/ Estimates. 
Table 29. Ghana: Index of Manufacturing Production, 1991-97

$$
(1977=100)
$$

\begin{tabular}{|c|c|c|c|c|c|c|c|c|}
\hline & Weights & 1991 & 1992 & 1993 & 1994 & 1995 & 1996 & $19971 /$ \\
\hline Food products & 15.00 & 59.3 & 62.8 & 90.3 & 90.8 & 99.6 & 102.5 & 109.3 \\
\hline Beverages & 8.11 & 93.0 & 112.2 & 105.5 & 109.4 & 109.0 & 116.2 & 123.9 \\
\hline Tobacco and tobacco products & 7.75 & 49.6 & 47.1 & 52.2 & 53.0 & 52.0 & 53.1 & 53.1 \\
\hline $\begin{array}{l}\text { Textiles, wearing apparel, } \\
\text { and leather goods }\end{array}$ & 13.71 & 39.1 & 23.7 & 60.2 & 48.0 & 54.8 & 56.1 & 55.5 \\
\hline Sawmill and wood products & 7.22 & 133.6 & 120.2 & 91.9 & 98.2 & 100.2 & 105.3 & 105.0 \\
\hline Paper products and printing & 1.94 & 49.3 & 54.6 & 33.7 & 47.1 & 45.1 & 49.3 & 54.1 \\
\hline Petroleum products & 19.00 & 92.2 & 65.0 & 65.8 & 94.4 & 101.4 & 103.5 & 7.3 \\
\hline $\begin{array}{l}\text { Chemical products other than } \\
\text { petroleum }\end{array}$ & 6.56 & 44.7 & 56.7 & 38.4 & 129.8 & 140.0 & 148.2 & 159.8 \\
\hline $\begin{array}{l}\text { Cement and other nonmetallic } \\
\text { mineral products }\end{array}$ & 2.98 & 125.6 & 177,0 & 206.2 & 217.0 & 258.1 & 258.9 & 241.8 \\
\hline Iron and steel products & 3.25 & $\ldots$ & 356.0 & 392.8 & 541.1 & 581.6 & 584.5 & 590.5 \\
\hline $\begin{array}{l}\text { Nonferrous metal basic } \\
\text { industries }\end{array}$ & 9.62 & 104.6 & 115.8 & 109.9 & 88.8 & 119.8 & 125.6 & 149.9 \\
\hline $\begin{array}{l}\text { Cutlery and other nonferrous } \\
\text { metal products }\end{array}$ & 0.49 & 63.2 & 83.3 & 99.9 & 124.0 & 102.4 & 116.4 & 116.4 \\
\hline $\begin{array}{l}\text { Electrical equipment and } \\
\text { appliances }\end{array}$ & 1.34 & 40.0 & 46.3 & 52.6 & 29.8 & 42.9 & 53.5 & 67.8 \\
\hline $\begin{array}{l}\text { Transport equipment and other } \\
\text { products } \\
\text { Overall index }\end{array}$ & $\begin{array}{r}3.03 \\
100.00\end{array}$ & $\begin{array}{r}\cdots \\
71.3\end{array}$ & $\begin{array}{l}11.0 \\
76.9\end{array}$ & $\begin{aligned} \ldots \\
87.3\end{aligned}$ & 101.2 & 109.9 & $\begin{aligned} \ldots \\
115.0\end{aligned}$ & $\begin{aligned} \cdots \\
101.0\end{aligned}$ \\
\hline $\begin{array}{l}\text { Memorandum items: } \\
\text { Percentage change in } \\
\text { overall index }\end{array}$ & & 12.3 & 7.9 & 13.5 & 15.9 & 8.6 & 4.6 & -12.2 \\
\hline $\begin{array}{l}\text { Average capacity utilization } \\
\text { (in percent) } 2 /\end{array}$ & & 40.5 & 44.5 & 45.7 & $\cdots$ & $\cdots$ & $\ldots$ & $\cdots$ \\
\hline
\end{tabular}

Sources: Statistical Service, Quarterly Digest of Statistics.

1/ Provisional.

2/ For large and medium-scale factories. 
Table 30. Ghana: Generation and Consumption of Electricity, 1989-1997

(In billions of kilowatt-hours)

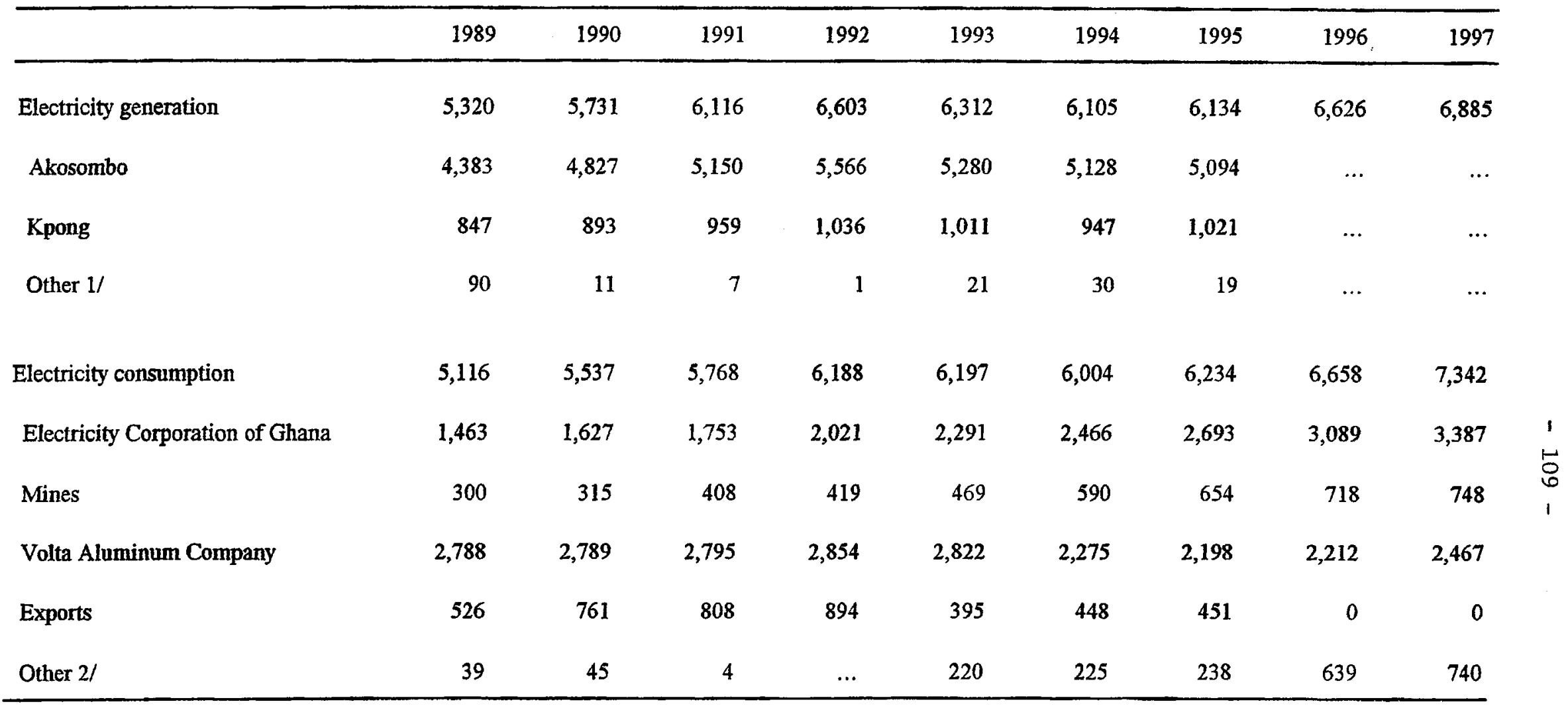

Source: Ministry of Fuel and Power.

1/ Including amounts generated by diesel units operated by the Electricity Corporation of Ghana and mining companies.

2/ Refers to Akosombo Township, Akosombo Textiles, and Aluworks and NED (1993 only). 
Table 31. Ghana: Average Monthly Earnings per Employee, 1980-97 1/

(Cedis per month)

\begin{tabular}{|c|c|c|c|c|c|c|c|c|c|}
\hline & $\begin{array}{c}\text { All } \\
\text { sectors }\end{array}$ & $\begin{array}{l}\text { Agriculture, } \\
\text { forestry, } \\
\text { and fishing }\end{array}$ & $\begin{array}{l}\text { Mining } \\
\text { and } \\
\text { quarrying }\end{array}$ & $\begin{array}{l}\text { Manu- } \\
\text { facturing }\end{array}$ & $\begin{array}{c}\text { Con- } \\
\text { struction }\end{array}$ & $\begin{array}{r}\text { Commerce } \\
\text { cor }\end{array}$ & $\begin{array}{l}\text { nsport, } \\
\text { age, and } \\
\text { anications }\end{array}$ & $\begin{array}{c}\text { Finance } \\
\text { insurance, } \\
\text { etc. }\end{array}$ & $\begin{array}{c}\text { Minimum } \\
\text { wage 2/ }\end{array}$ \\
\hline \multicolumn{10}{|c|}{ (Private sector) } \\
\hline 1980 & 581 & 416 & 676 & 567 & 552 & 803 & 603 & 516 & 5.33 \\
\hline 1981 & 672 & 683 & 785 & 713 & $\ldots$ & ... & 955 & 647 & 12.00 \\
\hline 1982 & 868 & 734 & 1,616 & 841 & 533 & 1,197 & 999 & 949 & 12.00 \\
\hline 1983 & 1,301 & 1,173 & 1,643 & 1,345 & 842 & 1,529 & 1,701 & 962 & $25.003 /$ \\
\hline 1984 & 3,280 & 2,973 & 4,074 & 3,940 & 1,615 & 2,958 & 2,671 & 2,602 & $35.004 /$ \\
\hline 1985 & 4,702 & 3,264 & 5,994 & 5,535 & 3,032 & 4,781 & 6,509 & 7,331 & $70.005 /$ \\
\hline 1986 & 7,956 & 5,454 & 6,480 & 8,453 & 4,970 & 8,240 & 11,846 & 15,179 & 90.00 \\
\hline 1987 & 15,310 & 8,749 & 8,506 & 15,859 & 7,273 & 12,104 & 12,930 & 17,352 & 112.50 \\
\hline 1988 & 18,660 & 13,317 & 14,433 & 21,755 & 8,502 & 17,811 & 22,170 & 22,131 & 146.25 \\
\hline 1989 & 35,356 & 19,077 & 22,488 & 43,067 & 12,567 & 21,695 & 41,466 & 58,497 & 170.00 \\
\hline 1990 & 39,566 & 23,094 & 27,340 & 51,482 & 18,766 & 28,485 & 36,121 & 63,985 & 218.00 \\
\hline 1991 & 37,174 & 18,308 & 39,490 & 31,659 & 30,167 & 29,762 & 60,636 & 100,761 & $460.006 \mathrm{l}$ \\
\hline 1992 & $\ldots$ & $\ldots$ & $\ldots$ & $\ldots$ & $\cdot \quad \ldots$ & $\ldots$ & $\cdots$ & $\ldots$ & $460.006 /$ \\
\hline \multicolumn{10}{|c|}{ (Public sector) } \\
\hline 1980 & 441 & 332 & 612 & 527 & 328 & 417 & 530 & 452 & 5.33 \\
\hline 1981 & 579 & 490 & 862 & 631 & 516 & 481 & 614 & 557 & 12.00 \\
\hline 1982 & 607 & 543 & 863 & 709 & 518 & 577 & 714 & 570 & 12.00 \\
\hline 1983 & 1,071 & 833 & 2,214 & 1,256 & 891 & 859 & 1,014 & 928 & $25.003 /$ \\
\hline 1984 & 2,122 & 2,199 & 3,354 & 2,399 & 1,564 & 1,405 & 2,302 & 2,080 & 35.0041 \\
\hline 1985 & 3,461 & 2,675 & 10,534 & 4,108 & 2,474 & 2,689 & 3,503 & 4,254 & $70.005 /$ \\
\hline 1986 & 7,333 & 5,787 & 12,024 & 9,520 & 5,109 & 5,395 & 10,312 & 7,597 & 90.00 \\
\hline 1987 & 9,324 & 8,269 & 17,200 & 15,505 & 6,923 & 9,528 & $\ldots$ & 13,639 & 112.50 \\
\hline 1988 & 12,738 & 10,379 & 11,331 & 20,047 & 8,836 & 12,393 & 17,802 & 19,098 & 146.25 \\
\hline 1989 & 21,869 & 20,527 & 16,742 & 17,573 & 14,090 & 20,321 & 23,579 & 37,25671 & 170.00 \\
\hline 1990 & 28,037 & 20,798 & 38,827 & 22,266 & 19,406 & 23,605 & 32,211 & $30,4847 f$ & 218.00 \\
\hline 1991 & 34,826 & 39,565 & 26,760 & 44,804 & 23,250 & 30,490 & 37,255 & 45,107 & $460.006 /$ \\
\hline 1992 & $\ldots$ & $\ldots$ & $\ldots$ & $\ldots$ & $\ldots$ & .. & $\cdots$ & $\ldots$ & 460.0061 \\
\hline \multicolumn{10}{|c|}{ (Total economy) } \\
\hline 1984 & 2,287 & 2,298 & 3,370 & 3,441 & 1,573 & 1,843 & 2,321 & $\ldots$ & 33.9641 \\
\hline 1985 & 3,633 & 2,753 & 10,471 & 5,059 & 2,602 & 3,348 & 3,631 & 4,548 & $70.005 /$ \\
\hline 1986 & 7,433 & 5,740 & 11,920 & 8,787 & 5,076 & 6,200 & 10,408 & 8,422 & 90.00 \\
\hline 1987 & 10,524 & 7,955 & 17,017 & 15,216 & 6,882 & 9,483 & $\ldots$ & 13,877 & 112.50 \\
\hline 1988 & 13,805 & 10,594 & 11,523 & 21,411 & 13,465 & 13,923 & 17,948 & 19,374 & 146.25 \\
\hline 1989 & 24,257 & 19,608 & 17,177 & 36,793 & 13,879 & 20,857 & 26,013 & 43,068 & 170.00 \\
\hline 1990 & 30,056 & 20,948 & 38,028 & 45,045 & 19,183 & 25,375 & 32,560 & 33,650 & 218.00 \\
\hline 1991 & 35,212 & 39,231 & 27,417 & 34,226 & 25,738 & 30,689 & 39,119 & 50,016 & $460.006 /$ \\
\hline 1992 & $\ldots$ & $\ldots$ & $\ldots$ & $\ldots$ & $\ldots$ & $\ldots$ & $\ldots$ & $\ldots$ & $460.006 /$ \\
\hline 1993 & $\ldots$ & $\ldots$ & $\ldots$ & $\ldots$ & $\ldots$ & $\ldots$ & $\ldots$ & $\ldots$ & 602.80 \\
\hline 1994 & $\ldots$ & $\cdots$ & $\ldots$ & $\ldots$ & $\cdots$ & $\ldots$ & $\ldots$ & $\ldots$ & 790.00 \\
\hline 1995 & $\ldots$ & $\ldots$ & $\ldots$ & $\ldots$ & $\ldots$ & $\ldots$ & $\ldots$ & $\ldots$ & $1,200.00$ \\
\hline 1996 & $\ldots$ & $\ldots$ & $\ldots$ & $\ldots$ & $\ldots$ & $\ldots$ & $\cdots$ & $\ldots$ & $1,700.00$ \\
\hline 1997 & $\ldots$ & $\ldots$ & $\ldots$ & $\ldots$ & $\ldots$ & $\ldots$ & $\ldots$ & $\ldots$ & $2,000.00$ \\
\hline
\end{tabular}

Source: Statistical Service.

1/ December data for the year indicated.

2/ Cedis per day.

3/ From April 1983.

4/ From April 1984.

5/ From December 1984.

6/ From July 1991.

7/ Excludes allowances and other regularly paid bonuses and honoraria. 
Table 32. Ghana: National Consumer index, 1985-97 (Monthly averages; $1977=100$ )

\begin{tabular}{|c|c|c|c|c|c|c|c|c|c|c|c|}
\hline (weight) & $\begin{array}{l}\text { Overall } \\
\text { index } \\
(100.0)\end{array}$ & $(49.2)$ & $\begin{array}{l}\text { Nonfood } \\
(50.8)\end{array}$ & $\begin{array}{l}\text { Beverages } \\
\text { and } \\
\text { tobacco } \\
(6.2)\end{array}$ & $\begin{array}{c}\text { Clothing } \\
\text { and } \\
\text { footwear } \\
(19.2)\end{array}$ & $\begin{array}{l}\text { Rent, } \\
\text { fuel, } \\
\text { and power } \\
(6.8)\end{array}$ & $\begin{array}{l}\text { Furnish- } \\
\text { ings 1/ } \\
(5.1)\end{array}$ & $\begin{array}{l}\text { Medical } \\
\text { care and } \\
\text { health } \\
(1.8)\end{array}$ & $\begin{array}{l}\text { Transport } \\
\text { and com- } \\
\text { munications } \\
\quad(4.3)\end{array}$ & $\begin{array}{l}\text { Recrea- } \\
\text { tion } 2 f \\
(5.5)\end{array}$ & $\begin{array}{l}\text { Miscel- } \\
\text { laneous 3/ } \\
\text { (1.9) }\end{array}$ \\
\hline 1985 & $3,647.2$ & $2,717.7$ & $4,547.4$ & $4,801.5$ & $4,643.7$ & $3,372.8$ & $5,404.0$ & $4,100.2$ & $4,741.5$ & $4,435.3$ & $4,987.1$ \\
\hline 1986 & $4,543.1$ & $3,268.8$ & $5,777.3$ & $6,369.4$ & $5,732.6$ & $4,807.3$ & $6,829.0$ & $4,754.5$ & $6,364.6$ & $5,317.0$ & $5,917.2$ \\
\hline 1987 & $6,352.0$ & $4,527.1$ & $8,119.4$ & $8,826.8$ & $8,373.7$ & $6,740.6$ & $9,703.9$ & $5,908.9$ & $8,551.8$ & $7,253.9$ & $7,543.9$ \\
\hline 1988 & $8,343.9$ & $6,071.0$ & $10,545.2$ & $11,478.5$ & $10,884.0$ & $9,134.5$ & $12,327.1$ & $7,519.2$ & $11,163.0$ & $9,038.9$ & $10,170.9$ \\
\hline 1989 & $10,449.3$ & $7,593.8$ & $13,214.9$ & $14,619.4$ & $13,469.1$ & $11,421.7$ & $15,034.9$ & $8,580.3$ & $14,551.5$ & $12,015.6$ & $12,433.7$ \\
\hline 1990 & $14,341.5$ & $10,643.8$ & $17,922.8$ & $19,342.5$ & $17,422.5$ & $17,284.9$ & $19,861.4$ & $11,663.7$ & $21,778.1$ & $16,647.8$ & $16,231.4$ \\
\hline 1991 & $16,927.4$ & $11,599.1$ & $22,088.0$ & $22,215.7$ & $20,135.7$ & $24,940.4$ & $22,559.1$ & $14,684.2$ & $30,827.5$ & $21,731.5$ & $18,585.1$ \\
\hline 1992 & $18,629.8$ & $12,800.4$ & $24,275.6$ & $23,486.1$ & $21,875.4$ & $30,069.0$ & $23,869.1$ & $15,627.3$ & $31,500.5$ & $25,185.9$ & $20,747.9$ \\
\hline 1993 & $23,279.7$ & $15,994.6$ & $30,335.4$ & $29,151.3$ & $25,733.4$ & $39,397.7$ & $29,445.6$ & $17,242.6$ & $42,024.8$ & $33,829.6$ & $26,517.8$ \\
\hline 1994 & $29,069.5$ & $20,160.5$ & $37,697.8$ & $35,994.0$ & $32,586.9$ & $46,084.1$ & $37,624.7$ & $19,582.6$ & $49,862.0$ & $45,666.9$ & $32,432.3$ \\
\hline 1995 & $46,354.6$ & $32,660.9$ & $59,617.1$ & $55,025.0$ & $52,277.1$ & $67,336.7$ & $57,613.3$ & $25,778.9$ & $83,463.1$ & $79,041.5$ & $48,387.5$ \\
\hline 1996 & $67,937.8$ & $44,344.9$ & $90,787.6$ & $81,723.5$ & $80,507.6$ & $90,500.2$ & $86,255.4$ & $36,771.7$ & $164,556.9$ & $108,897.4$ & $69,239.6$ \\
\hline 1997 & $86,882.2$ & $53,630.8$ & $119,086.4$ & $107,583.0$ & $101,205.9$ & $122,027.4$ & $105,930.4$ & $44,480.5$ & $229,453.2$ & $151,253.2$ & $89,886.5$ \\
\hline \multicolumn{12}{|l|}{1995} \\
\hline Q1 & $36,591.8$ & $25,506.6$ & $47,327.8$ & $43,641.0$ & $40,839.4$ & $55,423.7$ & $45,625,6$ & $21,721.0$ & $64,332.3$ & $63,759.8$ & $38,729.1$ \\
\hline Q2 & $43,642.7$ & $30,404.8$ & $56,463.6$ & $51,943.0$ & $48,820.0$ & $66,290.0$ & $54,105.4$ & $23,991.4$ & $80,523.8$ & $73,719.5$ & $45,976.1$ \\
\hline Q3 & $50,286.9$ & $35,978.0$ & $64,144.8$ & $58,612.8$ & $56,171.0$ & $70,098.5$ & $61,917.2$ & $27,791.4$ & $92,243.9$ & $86,875.8$ & $52,495.1$ \\
\hline Q4 & $54,897.2$ & $38,754,3$ & $70,532.2$ & $65,903.1$ & $63,278.0$ & $77,534.4$ & $68,804.7$ & $29,611.7$ & $96,752.5$ & $91,810.7$ & $56,249.7$ \\
\hline \multicolumn{12}{|l|}{1996} \\
\hline Q1 & $61,203.8$ & $41,761.7$ & $80,033.8$ & $73,638.4$ & $72,029.4$ & $85,454.7$ & $77,895.4$ & $33,311.9$ & $124,818.3$ & $96,941.5$ & $62,093.2$ \\
\hline$Q^{2}$ & $67,241.8$ & $44,282.5$ & $89,478.1$ & $79,233.1$ & $79,050.5$ & $89,186.1$ & $87,995.7$ & $37,094.9$ & $161,120.2$ & $108,164.7$ & $66,701.1$ \\
\hline $\mathrm{Q} 3$ & $70,098.1$ & $45,019.9$ & $94,386.6$ & $82,768.3$ & $83,996.4$ & $92,545.4$ & $88,808.4$ & $38,012.1$ & 179.722 .7 & $110,432.2$ & $72,686.4$ \\
\hline Q4 & $73,207.3$ & $46,315.8$ & $99,251.9$ & $91,254.2$ & $86,953.5$ & $94,314.5$ & $90,822.3$ & $38,668.0$ & $192,566.4$ & $120,051.3$ & $75,477.8$ \\
\hline \multicolumn{12}{|l|}{1997} \\
\hline $\mathrm{Q} 1$ & $79,808.7$ & $50,174.8$ & $108,509.3$ & $98,912.7$ & $93,751.5$ & $106,542.4$ & $97,039.7$ & $40,469.1$ & $209,938.4$ & $135,361.2$ & $83,961.7$ \\
\hline Q2 & $86,901.1$ & $54,945.6$ & $117,850.1$ & $104,703.2$ & $100,680.6$ & $123,490.8$ & $104,079.4$ & $43,487,3$ & $229,655.4$ & $145,479.3$ & $88,465.8$ \\
\hline$Q^{3}$ & $89,985.1$ & $55,220.5$ & $123,654.7$ & $110,636.8$ & $104,500.5$ & $128,508.6$ & $110,318.6$ & $46,021.5$ & $238,523.6$ & $157,898.6$ & $92,572.3$ \\
\hline Q4 & $90,834.1$ & $54,182.4$ & $126,331.5$ & $116,079.5$ & $1,058,980.9$ & $129,567.7$ & $112,283.7$ & $47,944.1$ & $239,695.2$ & $166,273.9$ & $94,546.4$ \\
\hline \multicolumn{12}{|c|}{$\begin{array}{l}\text { Sources: Statistical Services; and staff estimates. } \\
\text { 1/ Including furniture, fumishings, and housebold } \\
\text { 2/ Including recreation, entertainment, education, } \\
\text { 3/ Including miscellaneous goods and services. }\end{array}$} \\
\hline
\end{tabular}

(CInternational Monetary Fund. Not for Redistribution 
Table 33. Ghana: National Consumer Index, 1998 Q1-Q2 1/

(Monthly averages; September $1977=100$ )

\begin{tabular}{|c|c|c|c|c|c|c|c|c|c|c|c|}
\hline (weight) & $\begin{array}{l}\begin{array}{c}\text { Overall } \\
\text { index }\end{array} \\
(100.0)\end{array}$ & $\begin{array}{l}\text { Food } \\
\text { (51.9) }\end{array}$ & $\begin{array}{l}\text { Nonfood } \\
\text { (48.1) }\end{array}$ & $\begin{array}{c}\text { Beverages } \\
\text { and } \\
\text { tobaceo } \\
(3.6)\end{array}$ & $\begin{array}{c}\text { Clothing } \\
\text { and } \\
\text { footwear } \\
(9.6)\end{array}$ & $\begin{array}{l}\text { Rent, } \\
\text { fuel, } \\
\text { and power } \\
\text { (9.2) }\end{array}$ & $\begin{array}{c}\text { Fumish- } \\
\text { ings 2/ } \\
\text { (7.3) }\end{array}$ & $\begin{array}{c}\text { Medical } \\
\text { care and } \\
\text { health } \\
(4.3)\end{array}$ & $\begin{array}{c}\text { Transport } \\
\text { and com- } \\
\text { munications } \\
\text { (6.5) }\end{array}$ & $\begin{array}{l}\text { Recrea- } \\
\text { tion } 3 / \\
(4.9)\end{array}$ & $\begin{array}{c}\text { Miscel- } \\
\text { laneous 4/ } \\
\text { (2.8) }\end{array}$ \\
\hline \multicolumn{12}{|l|}{1998} \\
\hline Q1 & 106.2 & 108.8 & 104.0 & 102.8 & 104.2 & 106.8 & 103.5 & 99.9 & 102.0 & 101.9 & 109.4 \\
\hline Q2 & 118.2 & 127.4 & 110.1 & 108.2 & 107.5 & 115.8 & 108.1 & 112.9 & 109.1 & 106.4 & 115.3 \\
\hline
\end{tabular}

Sources: Statistical Services; and staff estimates

1/ Revised CPI.

2/ Including fumiture, fumishings, and household equipment and operations.

3/ Including recreation, entertainment, education, and cultural services.

4/ Including miscellaneous goods and services. 
Table 34. Ghana: National Consumer Price Index, 1987-97

\begin{tabular}{|c|c|c|c|c|c|c|c|c|c|c|c|}
\hline (weight) & $\begin{array}{l}\begin{array}{l}\text { Overall } \\
\text { index }\end{array} \\
(100.0)\end{array}$ & $\begin{array}{l}\text { Food } \\
(49.2)\end{array}$ & $\begin{array}{l}\text { Nonfood } \\
(50.8)\end{array}$ & $\begin{array}{l}\text { Beverages } \\
\text { and } \\
\text { tobacco } \\
(6.2)\end{array}$ & $\begin{array}{l}\text { Clothing } \\
\text { and } \\
\text { footwear } \\
(19.2)\end{array}$ & $\begin{array}{c}\text { Rent, } \\
\text { fuel, } \\
\text { and power } \\
(6.8)\end{array}$ & $\begin{array}{c}\text { Fumish- } \\
\text { ings 1/ } \\
(5.1)\end{array}$ & $\begin{array}{c}\text { Medical } \\
\text { care and } \\
\text { health } \\
(1.8)\end{array}$ & $\begin{array}{l}\text { Transport } \\
\text { and commu- } \\
\text { nications } \\
(4.3)\end{array}$ & $\begin{array}{l}\text { Recrea- } \\
\text { tion } 2 / \\
(5.5)\end{array}$ & $\begin{array}{c}\text { Miscel- } \\
\text { laneous 3/ } \\
(1.9)\end{array}$ \\
\hline $\begin{array}{l}1987 \\
1988 \\
1989 \\
1990 \\
1991 \\
1992 \\
1993 \\
1994 \\
1995 \\
1996 \\
1997\end{array}$ & $\begin{array}{l}34.2 \\
26.6 \\
30.5 \\
35.9 \\
10.3 \\
13.3 \\
27.7 \\
34.2 \\
70.8 \\
32.7 \\
20.8\end{array}$ & $\begin{array}{r}35.7 \\
26.5 \\
31.9 \\
32.0 \\
4.6 \\
17.0 \\
26.2 \\
40.2 \\
67.2 \\
20.8 \\
13.9\end{array}$ & $\begin{array}{l}33.4 \\
26.6 \\
29.7 \\
38.1 \\
13.3 \\
11.5 \\
28.4 \\
31.2 \\
72.8 \\
29.0 \\
24.0\end{array}$ & $\begin{array}{r}32.9 \\
26.8 \\
34.9 \\
24.2 \\
10.3 \\
8.2 \\
28.2 \\
32.9 \\
71.4 \\
37.1 \\
22.5\end{array}$ & $\begin{array}{r}33.5 \\
26.4 \\
28.3 \\
24.9 \\
11.0 \\
9.0 \\
23.8 \\
36.4 \\
78.0 \\
32.4 \\
18.6\end{array}$ & $\begin{array}{l}33.5 \\
32.1 \\
31.6 \\
58.2 \\
33.7 \\
16.0 \\
32.9 \\
21.6 \\
56.1 \\
22.8 \\
34.0\end{array}$ & $\begin{array}{r}29.9 \\
22.6 \\
28.4 \\
26.9 \\
8.3 \\
8.1 \\
28.8 \\
36.6 \\
64.0 \\
29.9 \\
21.6\end{array}$ & $\begin{array}{r}29.9 \\
21.7 \\
16.3 \\
39.3 \\
18.5 \\
5.8 \\
11.6 \\
17.2 \\
47.4 \\
28.4 \\
22.4\end{array}$ & $\begin{array}{r}36.6 \\
24.9 \\
27.8 \\
89.4 \\
11.2 \\
3.9 \\
34.9 \\
22.8 \\
86.6 \\
95.1 \\
23.7\end{array}$ & $\begin{array}{r}37.2 \\
26.6 \\
33.5 \\
56.0 \\
6.8 \\
29.4 \\
30.6 \\
40.2 \\
82.5 \\
34.6 \\
31.4\end{array}$ & $\begin{array}{l}30.2 \\
30.4 \\
26.8 \\
24.0 \\
11.4 \\
13.6 \\
34.0 \\
25.9 \\
60.6 \\
33.9 \\
22.4\end{array}$ \\
\hline $\begin{array}{l}1995 \\
\text { January } \\
\text { February } \\
\text { March } \\
\text { April } \\
\text { May } \\
\text { June } \\
\text { July } \\
\text { August } \\
\text { September } \\
\text { October } \\
\text { November } \\
\text { December }\end{array}$ & $\begin{array}{l}35.6 \\
38.4 \\
43.6 \\
49.9 \\
56.1 \\
61.9 \\
67.2 \\
69.9 \\
69.8 \\
69.1 \\
70.2 \\
70.8\end{array}$ & $\begin{array}{l}41.1 \\
43.8 \\
46.5 \\
51.9 \\
57.8 \\
63.8 \\
70.6 \\
72.9 \\
75.0 \\
73.0 \\
70.3 \\
67.9\end{array}$ & $\begin{array}{l}32.8 \\
36.1 \\
42.1 \\
49.0 \\
55.2 \\
60.8 \\
65.4 \\
68.4 \\
67.1 \\
67.1 \\
70.2 \\
72.8\end{array}$ & $\begin{array}{l}30.4 \\
31.8 \\
35.6 \\
42.8 \\
49.6 \\
54.2 \\
59.1 \\
59.1 \\
59.6 \\
62.4 \\
68.4 \\
71.4\end{array}$ & $\begin{array}{l}39.0 \\
40.2 \\
43.4 \\
50.5 \\
57.1 \\
63.7 \\
63.9 \\
68.3 \\
69.8 \\
67.3 \\
71.3 \\
78.0\end{array}$ & $\begin{array}{l}21.0 \\
22.9 \\
37.2 \\
42.6 \\
47.5 \\
48.8 \\
49.9 \\
50.6 \\
52.5 \\
56.2 \\
62.2 \\
56.1\end{array}$ & $\begin{array}{l}33.8 \\
34.8 \\
38.0 \\
42.8 \\
48.3 \\
57.3 \\
58.1 \\
62.1 \\
61.3 \\
61.1 \\
64.9 \\
64.0\end{array}$ & $\begin{array}{l}12.9 \\
14.6 \\
17.1 \\
20.6 \\
24.0 \\
27.9 \\
36.9 \\
41.3 \\
43.8 \\
47.4 \\
41.5 \\
47.4\end{array}$ & $\begin{array}{l}20.7 \\
36.3 \\
49.8 \\
57.5 \\
62.0 \\
70.3 \\
79.8 \\
84.7 \\
85.3 \\
84.8 \\
81.6 \\
86.6\end{array}$ & $\begin{array}{l}46.3 \\
49.8 \\
53.5 \\
62.4 \\
72.3 \\
76.4 \\
93.7 \\
97.2 \\
78.3 \\
78.5 \\
79.6 \\
82.5\end{array}$ & $\begin{array}{l}26.3 \\
28.8 \\
32.4 \\
39.8 \\
46.1 \\
52.0 \\
60.3 \\
59.2 \\
59.1 \\
58.1 \\
59.6 \\
60.6\end{array}$ \\
\hline $\begin{array}{l}1996 \\
\text { January } \\
\text { February } \\
\text { March } \\
\text { April } \\
\text { May } \\
\text { June } \\
\text { July } \\
\text { August } \\
\text { September } \\
\text { October } \\
\text { November } \\
\text { December }\end{array}$ & $\begin{array}{l}69.2 \\
68.0 \\
64.8 \\
60.3 \\
54.2 \\
48.4 \\
42.6 \\
39.2 \\
36.5 \\
34.3 \\
33.2 \\
32.7\end{array}$ & $\begin{array}{l}65.0 \\
65.2 \\
61.2 \\
54.1 \\
45.6 \\
38.3 \\
29.6 \\
24.9 \\
21.1 \\
18.8 \\
19.0 \\
20.8\end{array}$ & $\begin{array}{l}71.4 \\
69.5 \\
66.6 \\
63.4 \\
58.8 \\
53.8 \\
49.7 \\
46.9 \\
45.0 \\
28.5 \\
30.6 \\
29.0\end{array}$ & $\begin{array}{l}73.5 \\
67.8 \\
65.3 \\
58.1 \\
53.7 \\
46.5 \\
42.1 \\
39.7 \\
41.9 \\
39.0 \\
39.5 \\
37.1\end{array}$ & $\begin{array}{l}78.3 \\
75.4 \\
75.5 \\
70.3 \\
61.0 \\
55.5 \\
54.5 \\
48.9 \\
45.5 \\
42.7 \\
37.9 \\
32.4\end{array}$ & $\begin{array}{l}57.5 \\
60.5 \\
45.8 \\
37.6 \\
33.0 \\
33.2 \\
33.3 \\
33.1 \\
29.7 \\
25.5 \\
18.8 \\
22.8\end{array}$ & $\begin{array}{l}68.6 \\
72.4 \\
71.1 \\
72.1 \\
63.9 \\
53.2 \\
49.6 \\
42.8 \\
38.3 \\
34.3 \\
29.8 \\
29.9\end{array}$ & $\begin{array}{l}52.9 \\
50.2 \\
56.8 \\
52.4 \\
62.4 \\
49.2 \\
40.3 \\
36.0 \\
34.2 \\
29.4 \\
34.1 \\
28.4\end{array}$ & $\begin{array}{r}99.5 \\
91.8 \\
91.8 \\
96.3 \\
104.7 \\
99.2 \\
91.8 \\
95.1 \\
97.4 \\
100.0 \\
102.2 \\
95.1\end{array}$ & $\begin{array}{l}55.2 \\
51.7 \\
49.4 \\
50.7 \\
47.7 \\
42.2 \\
30.0 \\
27.0 \\
24.4 \\
24.9 \\
32.5 \\
34.6\end{array}$ & $\begin{array}{l}62.8 \\
59.4 \\
59.0 \\
51.9 \\
39.8 \\
44.0 \\
37.8 \\
38.8 \\
39.0 \\
35.4 \\
32.5 \\
33.3\end{array}$ \\
\hline $\begin{array}{l}1997 \\
\text { January } \\
\text { February } \\
\text { March } \\
\text { April } \\
\text { May } \\
\text { June } \\
\text { July } \\
\text { August } \\
\text { September } \\
\text { October } \\
\text { November } \\
\text { December }\end{array}$ & $\begin{array}{l}31.5 \\
30.6 \\
29.2 \\
29.1 \\
29.6 \\
29.0 \\
29.2 \\
28.2 \\
27.7 \\
27.4 \\
24.2 \\
20.8\end{array}$ & $\begin{array}{l}21.2 \\
19.2 \\
20.1 \\
23.4 \\
24.7 \\
24.2 \\
24.8 \\
22.8 \\
20.3 \\
20.0 \\
17.2 \\
13.9\end{array}$ & $\begin{array}{l}27.3 \\
23.8 \\
19.9 \\
17.6 \\
31.9 \\
31.4 \\
31.2 \\
30.7 \\
31.1 \\
45.3 \\
37.2 \\
33.4\end{array}$ & $\begin{array}{l}34.3 \\
35.4 \\
33.4 \\
33.4 \\
30.5 \\
32.7 \\
33.9 \\
33.8 \\
33.4 \\
33.5 \\
26.1 \\
22.5\end{array}$ & $\begin{array}{l}31.2 \\
31.1 \\
28.2 \\
26.8 \\
29.1 . \\
26.2 \\
25.8 \\
23.7 \\
23.7 \\
24.8 \\
22.1 \\
18.6\end{array}$ & $\begin{array}{l}31.2 \\
31.1 \\
28.2 \\
34.9 \\
41.5 \\
39.0 \\
39.5 \\
37.7 \\
39.4 \\
38.9 \\
37.2 \\
34.0\end{array}$ & $\begin{array}{l}27.6 \\
26.2 \\
21.2 \\
16.3 \\
18.4 \\
20.1 \\
22.3 \\
23.4 \\
27.1 \\
27.2 \\
24.3 \\
21.6\end{array}$ & $\begin{array}{l}21.1 \\
23.9 \\
19.6 \\
21.6 \\
11.7 \\
18.8 \\
20.1 \\
21.2 \\
21.9 \\
24.3 \\
25.4 \\
22.4\end{array}$ & $\begin{array}{l}82.8 \\
68.8 \\
56.1 \\
46.1 \\
39.7 \\
42.1 \\
39.0 \\
30.9 \\
28.7 \\
25.2 \\
24.6 \\
23.7\end{array}$ & $\begin{array}{l}37.5 \\
38.6 \\
42.7 \\
37.4 \\
32.6 \\
33.6 \\
33.6 \\
46.5 \\
48.9 \\
47.7 \\
37.6 \\
31.4\end{array}$ & $\begin{array}{l}33.0 \\
37.8 \\
34.9 \\
32.0 \\
38.1 \\
28.2 \\
28.5 \\
27.1 \\
26.5 \\
25.8 \\
27.8 \\
22.4\end{array}$ \\
\hline
\end{tabular}

1/ Including fumiture, furnishings, and household equipment and operations.

2/ Including recreation, entertainment, education, and cultural services.

3/ Including miscellaneous goods and services. 
Table 35. Ghana: Average Wholesale Prices of Selected

Agricultural Commodities, 1989-97

(In cedis per unit)

\begin{tabular}{lrrrrrrrrrrr}
\hline & $\begin{array}{c}\text { Unit of } \\
\text { measurement }\end{array}$ & 1989 & 1990 & 1991 & 1992 & 1993 & 1994 & 1995 & 1996 & 1997 \\
\hline Maize & $100 \mathrm{~kg}$. & 5,424 & 8,633 & 9,434 & 10,048 & 11,938 & 13,863 & 24,708 & 32,814 & 64,326 \\
Millet & $93 \mathrm{~kg}$. & 10,633 & 10,956 & 14,362 & 14,632 & 17,060 & 18,357 & 30,527 & 42,784 & 69,918 \\
Guinea corn & $109 \mathrm{~kg}$. & 9,415 & 10,603 & 13,404 & 14,544 & 17,169 & 17,918 & 29,757 & 43,210 & 67,156 \\
Rice & $100 \mathrm{~kg}$. & 18,132 & 18,503 & 19,277 & 21,179 & 26,970 & 35,164 & 55,159 & 80,270 & 104,707 \\
Yams & 100 tubers & 23,668 & 30,102 & 29,469 & 29,070 & 43,582 & 53,310 & 82,219 & 87,427 & 142,086 \\
Cocoyams & $91 \mathrm{~kg}$. & 5,354 & 7,984 & 7,680 & 9,117 & 11,725 & 16,017 & 26,679 & 25,301 & 42,306 \\
Cassava & $91 \mathrm{~kg}$. & 2,510 & 4,274 & 4,000 & 4,048 & 5,342 & 5,733 & 9,550 & 10,269 & 15,878 \\
Plantain & $16 \mathrm{~kg}$. & 698 & 1,109 & 887 & 1,069 & 1,698 & 1,940 & 4,160 & 3,693 & 6,538 \\
Cowpeas & $109 \mathrm{~kg}$. & 17,734 & 20,479 & 23,059 & 21,861 & 30,988 & 35,991 & 46,428 & 97,907 & 109,470 \\
Tomatoes & $51 \mathrm{~kg}$. & 4,934 & 6,969 & 11,150 & 13,380 & 24,352 & 14,575 & 25,023 & 34,866 & 56,857 \\
Groundnuts & $82 \mathrm{~kg}$. & 16,275 & 17,205 & 20,670 & 25,973 & 33,114 & 34,576 & 54,346 & 69,025 & 114,775 \\
\hline
\end{tabular}

Source: Ministry of Agriculture. 
Table 36. Ghana: Retail Prices of Major Petroleum Products,

December 1979-February 1998

(In cedis per liter) $1 /$

\begin{tabular}{|c|c|c|c|c|c|c|c|}
\hline $\begin{array}{l}\text { Date of Price } \\
\text { Change }\end{array}$ & $\begin{array}{r}\text { Premium } \\
\text { gasoline }\end{array}$ & $\begin{array}{l}\text { Regular } \\
\text { gasoline }\end{array}$ & Kerosene & Gas oil & ATK 2/ & RFO $3 /$ & LPG 4/ \\
\hline December 1, 1979 & 1.65 & 1.54 & 0.77 & $\ldots$ & $\ldots$ & $\ldots$ & $\ldots$ \\
\hline November 6, 1980 & 2.31 & 2.2 & 1.1 & 1.32 & $\cdots$. & $\ldots$ & 0.18 \\
\hline January 15,1981 & 2.49 & 2.27 & 1.21 & 1.43 & $\ldots$ & $\ldots$ & 0.18 \\
\hline June 18,1981 & 2.86 & 2.64 & 1.98 & 1.12 & $\therefore$ & $\ldots$ & 0.18 \\
\hline September 7, 1981 & 2.71 & 2.49 & 1.87 & 1.1 & $\ldots$ & $\ldots$ & 0.18 \\
\hline October 1,1982 & 2.71 & 2.49 & 1.1 & 1.87 & 1.28 & 0.71 & 0.18 \\
\hline April 22, 1983 & 5.5 & 4.73 & 2.9 & 3.5 & 3.63 & 3.02 & 0.37 \\
\hline October 11,1983 & 7.7 & 6.71 & 4.4 & 5.28 & 5.77 & 3.13 & 0.57 \\
\hline September 13,1984 & 13.2 & 12.32 & 7.7 & 10.12 & 9.9 & 5.9 & 1.58 \\
\hline October 5, 1984 & 18.7 & 17.6 & 10.12 & 15.4 & 14.3 & 9.35 & 2.06 \\
\hline April 19, 1985 & 20.9 & 19.8 & 11 & 17.6 & 15.76 & 10.3 & 2.23 \\
\hline September 9, 1985 & 23.1 & 22 & 12.1 & 18.7 & 17.6 & 10.3 & 1.39 \\
\hline January 16,1986 & 33 & 31.9 & 19.8 & 28.6 & 26.4 & 16.5 & 3.33 \\
\hline March 20, 1986 & 30.8 & 29.7 & 17.6 & 25.3 & 25.3 & 14.3 & 3.33 \\
\hline June 30, 1986 & 33 & 31.9 & 17.6 & 28.6 & 26.4 & 14.3 & 3.33 \\
\hline February 1, 1987 & 41.79 & 39.6 & 24.2 & 36.3 & 37.4 & 26.4 & 4.4 \\
\hline January 16,1988 & 51.69 & 50.59 & 37.4 & 49.49 & 48.39 & 29.92 & 6.6 \\
\hline January 13, 1989 & 60.6 & 59.5 & 41.8 & 55.1 & $\ldots$ & $\ldots$ & 88.18 \\
\hline January 11, 1990 & 79.3 & $\ldots$ & 59.4 & 72.7 & 75.05 & $\ldots$ & 100 \\
\hline March 31, 1990 & 88.1 & $\ldots$ & 66 & 81.4 & 67.13 & $\ldots$ & 100 \\
\hline September 2, 1990 & 133 & $\ldots$ & 100 & 111 & 93.48 & $\ldots$ & 100 \\
\hline November 3, 1990 & 222 & $\ldots$ & 178 & 189 & 180.38 & $\ldots$ & 100 \\
\hline January 3,1991 & 222 & $\cdots$ & 178 & 189 & 180.38 & $\ldots$ & 100 \\
\hline March 29, 1991 & 200 & $\ldots$ & 156 & 166 & 139.32 & $\ldots$ & 100 \\
\hline February 3, 1992 & 200 & $\ldots$ & 156 & 166 & 139.32 & $\ldots$ & 100 \\
\hline September 19,1992 & 222 & $\ldots$ & 156 & 188 & 161.32 & $\ldots$ & 100 \\
\hline January 6,1993 & 355 & $\ldots$ & 250 & 302 & 258 & $\ldots$ & 120 \\
\hline January 17, 1994 & 422 & $\ldots$ & 275 & 360 & $\ldots$ & $\ldots$ & 200 \\
\hline February 2, 1995 & 522 & $\ldots$ & 333 & 450 & $\ldots$ & 162.86 & 275.86 \\
\hline February 2, 1996 & 621.5 & $\ldots$ & 397 & 567 & $\ldots$ & 200.52 & 344 \\
\hline June 7, 1996 & 665.6 & $\ldots$ & 411 & 607.8 & 459.2 & 217.86 & 380 \\
\hline February 1, 1997 & 778.9 & $\ldots$ & 493.2 & 729.5 & 560 & 301.68 & 828.4 \\
\hline January 1, 1998 & 755.6 & $\cdots$ & 493.2 & 729.5 & $\ldots$ & $\ldots$ & 828.40 \\
\hline February 23, 1998 & 744.4 & $\ldots$ & 493.2 & 722.2 & $\ldots$ & $\ldots$ & 828.40 \\
\hline
\end{tabular}

Source: Ministry of Fuel and Power.

1/ Except LPG, which is in cedis $/ \mathrm{kg}$.

2/ Aviation turbine kerosene.

3/ Residual fuel oil.

4/ Liquefied petroleum gas. 
Table 37. Ghana: Central Government Operations and Financing, 1990-97 (In billions of cedis)

\begin{tabular}{|c|c|c|c|c|c|c|c|c|}
\hline & 1990 & 1991 & 1992 & 1993 & 1994 & 1995 & 1996 & 1997 \\
\hline Total revenue and grants & 296.6 & 429.6 & 425.1 & 742.8 & $1,160.2$ & $1,864.7$ & $2,288.6$ & $2,708.9$ \\
\hline Revenue & 239.4 & 354.4 & 333.6 & 578.1 & 975.8 & $1,584.6$ & $1,997.6$ & $2,446.7$ \\
\hline Direct taxes & 55.1 & 62.4 & 62.1 & 110.3 & 170.5 & 275.0 & 433.3 & 606.4 \\
\hline Indirect taxes & 99.5 & 172.8 & 164.2 & 277.5 & 395.8 & 503.7 & 732.4 & 833.4 \\
\hline Trade taxes & 65.0 & 84.3 & 75.5 & 121.4 & 274.8 & 359.9 & 544.9 & 630.2 \\
\hline Nontax revenue & 19.8 & 34.9 & 31.7 & 69.0 & 134.7 & 446.1 & 287.0 & 376.7 \\
\hline Foreign grants & 57.2 & 75.3 & 91.5 & 164.7 & 184.4 & 280.1 & 291.1 & 262.2 \\
\hline Total expenditure and net lending & 341.4 & 463.5 & 689.3 & $1,124.5$ & $1,621.8$ & $2,359.4$ & $3,370.2$ & $4,001.6$ \\
\hline Recurrent expenditure & 206.2 & 273.0 & 400.4 & 694.3 & 929.6 & $1,270.6$ & $1,861.1$ & $2,364.3$ \\
\hline Wages and salaries & 82.3 & 105.6 & 171.1 & 227.6 & 297.1 & 431.0 & 612.6 & 750.6 \\
\hline Goods and services & 45.0 & 60.5 & 69.2 & 141.2 & 170.0 & 190.1 & 242.9 & 283.8 \\
\hline Subsidies and transfers $1 /$ & 51.6 & 64.1 & 99.1 & 190.7 & 232.1 & 320.7 & 426.2 & 412.8 \\
\hline Interest & 27.3 & 42.8 & 61.0 & 134.8 & 230.5 & 328.8 & 579.3 & 917.0 \\
\hline Capital expenditure (total) & 135.2 & 190.5 & 288.9 & 430.2 & 692.2 & $1,088.8$ & $1,509.1$ & $1,637.3$ \\
\hline Capital expenditure (domestic) & 57.8 & 78.6 & 131.3 & 143.3 & 236.2 & 524.1 & 682.3 & 541.8 \\
\hline Development & 48.3 & 67.2 & 119.4 & 135.3 & 227.9 & 508.3 & 573.5 & 536.6 \\
\hline Net lending & 9.5 & 11.4 & 11.9 & 8.0 & 8.3 & 15.8 & 108.8 & 5.2 \\
\hline Capital expenditure (foreign) & 77.4 & 111.9 & 157.6 & 286.9 & 456.0 & 564.8 & 826.8 & $1,095.5$ \\
\hline Surplus or deficit (-) & -44.8 & -33.9 & -264.2 & -381.7 & 461.6 & -494.7 & $-1,081.6$ & $-1,292.7$ \\
\hline Domestic arrears (net change) & 0.0 & 0.0 & 21.0 & 16.0 & 9.0 & 81.0 & -11.7 & -84.0 \\
\hline Divestiture proceeds & 0.0 & 0.0 & 0.0 & 79.5 & 255.3 & 106.2 & 143.5 & 105.7 \\
\hline Financing & 44.6 & 33.9 & 243.2 & 286.2 & 197.3 & 307.5 & 949.0 & $1,271.0$ \\
\hline Foreign (net) & 72.6 & 85.6 & 99.1 & 240.9 & 236.2 & 335.8 & 418.0 & 508.8 \\
\hline Borrowing & 106.3 & 124.9 & 141.8 & 306.9 & 351.1 & 530.0 & 855.1 & 980.5 \\
\hline Repayments & -33.7 & -39.3 & -42.8 & -66.1 & -115.0 & -194.2 & -437.1 & -471.7 \\
\hline Domestic (net) & -28.0 & -51.7 & 144.2 & 45.4 & -38.8 & -28.3 & 531.0 & 762.2 \\
\hline Banking system & -20.8 & -50.7 & 102.5 & -22.1 & -44.3 & .66 .5 & 226.4 & 527.9 \\
\hline Other & -7.2 & -1.1 & 41.7 & 67.5 & 5.5 & 38.2 & 304.6 & 234.2 \\
\hline \multicolumn{9}{|c|}{ (In percent of GDP) } \\
\hline Total revenue and grants & 15.4 & 17.7 & 15.2 & 20.2 & 23.4 & 25.1 & 20.2 & 19.2 \\
\hline Of which: tax revenue & 11.4 & 13.2 & 10.8 & 13.9 & 17.0 & 15.3 & 15.1 & 14.7 \\
\hline Total expenditure and net lending & 17.8 & 19.1 & 24.6 & 30.6 & 32.8 & 31.8 & 29.7 & 28.4 \\
\hline Surplus or deficit $(-)$ & -2.3 & -1.4 & -9.4 & -10.4 & -9.3 & -6.7 & -9.5 & -9.2 \\
\hline Domestic primary balance $2 /$ & 0.1 & 1.9 & -4.9 & -3.4 & 0.8 & 1.6 & 0.3 & 3.2 \\
\hline Current savings $3 /$ & 1.7 & 3.4 & -2.4 & -3.2 & 0.9 & 4.2 & 1.2 & 0.6 \\
\hline
\end{tabular}

Sources: Data provided by the Ghanaian authorities; and staff estimates.

1/ Includes pensions to government employees.

2/ Defined as total revenue minus noninterest domestic expenditure.

3/ Defined as total revenue minus recurrent expenditure. 


$$
\text { - } 117 \text { - }
$$

Table 38. Ghana: Central Government Revenue and Grants, 1990-97

(In billions of cedis)

\begin{tabular}{|c|c|c|c|c|c|c|c|c|}
\hline & 1990 & 1991 & 1992 & 1993 & 1994 & 1995 & 1996 & 1997 \\
\hline Total revenue and grants & 296.6 & 429.6 & 425.1 & 742.8 & $1,160.2$ & $1,864.7$ & $2,288.6$ & $2,708.9$ \\
\hline Tax revenue & 219.7 & 319.5 & 301.8 & 509.2 & 841.1 & $1,138.5$ & $1,710.6$ & $2,070.0$ \\
\hline Direct taxes & 55.1 & 62.4 & 62.1 & 110.3 & 170.5 & 275.0 & 433.3 & 606.4 \\
\hline Individual & 17.4 & 18.7 & 21.1 & 44.3 & 62.3 & 80.8 & 131.1 & 225.1 \\
\hline Personal & 10.8 & 11.7 & 15.7 & 37.0 & 51.5 & 65.4 & 110.5 & 194.9 \\
\hline Self-employed & 6.6 & 7.0 & 5.4 & 7.3 & 10.9 & 15.4 & 20.6 & 30.2 \\
\hline Corporate & 34.0 & 39.9 & 34.5 & 54.3 & 89.5 & 157.2 & 242.3 & 293.1 \\
\hline Other & 3.7 & 3.8 & 6.5 & 11.7 & 18.7 & 37.0 & 59.9 & 88.3 \\
\hline Indirect taxes & 99.5 & 172.8 & 164.2 & 277.5 & 395.8 & 503.7 & 732.4 & 833.4 \\
\hline Sales tax & 50.7 & 64.5 & 66.4 & 94.3 & 144.3 & 210.1 & 329.6 & 407.4 \\
\hline Sales tax on domestic goods & 22.9 & 29.6 & $\mathbf{3 1 . 0}$ & 39.7 & 57.5 & 69.9 & 172.2 & 198.0 \\
\hline Sales taxes on imports & 27.8 & 34.9 & 35.4 & 54.6 & 86.8 & 140.1 & 157.4 & 209.4 \\
\hline Petroleum & 25.4 & 78.8 & 70.3 & 151.9 & 201.7 & 224.0 & 290.2 & 314.3 \\
\hline Excise & 23.4 & 29.5 & 27.5 & 31.2 & 49.8 & .69 .6 & 112.6 & 111.6 \\
\hline Trade taxes & 65.0 & 84.3 & 75.5 & 121.4 & 274.8 & 359.9 & 544.9 & 630.2 \\
\hline Import taxes & 37.8 & 48.1 & 55.2 & 85.6 & 128.7 & 202.6 & 267.2 & 364.3 \\
\hline Custöms duties & 34.5 & 43.5 & 49.5 & 72.1 & 106.1 & 162.5 & 214.2 & 277.2 \\
\hline Special tax & 2.5 & 3.7 & 5.3 & 7.6 & 5.0 & 6.4 & 11.2 & 16.6 \\
\hline Other import charges & 0.8 & 0.9 & 0.3 & 5.9 & 17.6 & 33.8 & 41.7 & 70.5 \\
\hline Export duty - cocoa & 27.2 & 36.2 & 20.4 & 35.7 & 146.2 & 157.2 & 277.7 & 265.9 \\
\hline Nontax revenue & 19.8 & 34.9 & 31.7 & 69.0 & 134.7 & 446.1 & 287.0 & 376.7 \\
\hline Grants & 57.2 & 75.3 & 91.5 & 164.7 & 184.4 & 280.1 & 291.1 & 262.2 \\
\hline Program grants & 27.8 & 36.3 & 32.7 & 66.6 & 49.5 & 93.8 & 78.4 & 64.2 \\
\hline Project grants & 29.4 & 39.0 & 58.8 & 98.1 & 134.9 & 186.3 & 212.7 & 198.0 \\
\hline & \multicolumn{8}{|c|}{ (In percent of GDP) } \\
\hline Direct taxes & 2.9 & 2.6 & 2.2 & 3.0 & 3.4 & 3.7 & 3.8 & 4.3 \\
\hline Indirect taxes & 5.2 & 7.1 & 5.9 & 7.6 & 8.0 & 6.8 & 6.5 & 5.9 \\
\hline Trade taxes & 3.4 & 3.5 & 2.7 & 3.3 & 5.6 & 4.9 & 4.8 & 4.5 \\
\hline Nontax revenue & 1.0 & 1.4 & 1.1 & 1.9 & 2.7 & 6.0 & 2.5 & 2.7 \\
\hline Grants & 3.0 & 3.1 & 3.3 & 4.5 & 3.7 & 3.8 & 2.6 & 1.9 \\
\hline Total revenue and grants & 15.4 & 17.7 & 15.2 & 20.2 & 23.4 & 25.1 & 20.2 & 19.2 \\
\hline
\end{tabular}

Source: Ministry of Finance 
Table 39. Ohana: Economic Classification of Central Government Expenditure and Net Lending, 1990-97 (In billions of cedis)

\begin{tabular}{|c|c|c|c|c|c|c|c|c|}
\hline & 1990 & 1991 & 1992 & 1993 & 1994 & 1995 & 1996 & 1997 \\
\hline Total expenditure and net lending & 341.4 & 463.5 & 689.3 & $1,124.5$ & $1,621.8$ & $2,359.4$ & $3,370.2$ & $4,001.6$ \\
\hline Current expenditure & 206.2 & 273.0 & 400.4 & 694.3 & 929.6 & $1,270.6$ & $1,861.1$ & $2,364.3$ \\
\hline Noninterest expenditure & 178.9 & 230.2 & 339.4 & 559.5 & 699.1 & 941.9 & $1,281.8$ & $1,447.3$ \\
\hline Wages and salaries & 82.3 & 105.6 & 171.1 & 227.6 & 297.1 & 431.0 & 612.6 & 750.6 \\
\hline Goods and services & 45.0 & 60.5 & 69.2 & 141.2 & 170.0 & 190.1 & 242.9 & 283.8 \\
\hline Items $2-5$ & 42.7 & 55.5 & 67.1 & 94.2 & 142.3 & 157.3 & 242.9 & 283.5 \\
\hline Other goods and services & 2.3 & 5.0 & 2.1 & 47.0 & 27.7 & 32.8 & 0.0 & 0.3 \\
\hline Subventions & 26.9 & 33.6 & 41.0 & 139.9 & 94.8 & 135.0 & 239.0 & 210.8 \\
\hline Transfers to households & 24.7 & 30.5 & 58.0 & 50.8 & 137.2 & 185.7 & 187.2 & 202.0 \\
\hline Pensions & 7.4 & 9.2 & 13.6 & $\ldots$ & 29.7 & 58.1 & 67.0 & 76.9 \\
\hline Gratuities & 3.5 & 4.3 & 5.0 & $\ldots$ & 7.1 & 28.6 & 38.7 & 54.7 \\
\hline Social security & 5.8 & 7.7 & 12.3 & $\ldots$ & 36.5 & 47.6 & 54.9 & 66.5 \\
\hline End-of-service benefits & 0.0 & 0.0 & 19.9 & 32.8 & 27.7 & 31.3 & 10.0 & 0.0 \\
\hline Other benefits & 8.0 & 9.3 & 7.2 & 18.0 & 36.3 & 20.1 & 16.6 & 4.0 \\
\hline Interest payments & 27.3 & 42.8 & 61.0 & 134.8 & 230.5 & 328.8 & 579.3 & 917.0 \\
\hline Domestic & 17.5 & 29.6 & 34.9 & 94.3 & 166.4 & 232.9 & 434.5 & 645.0 \\
\hline External & 9.8 & 13.2 & 26.1 & 40.4 & 64.0 & 95.8 & 144.8 & 272.0 \\
\hline Capital expenditure & 135.2 & 190.5 & 288.9 & 430.2 & 692.2 & $1,088.8$ & $1,509.1$ & $1,637.3$ \\
\hline Capital expenditure (domestic) & 57.8 & 78.6 & 131.3 & 143.3 & 236.2 & 524.1 & 682.3 & 541.8 \\
\hline Development & 48.3 & 67.2 & 119.4 & 135.3 & 227.9 & 508.3 & 573.5 & 536.6 \\
\hline Net lending & 9.5 & 11.4 & 11.9 & 8.0 & 8.3 & 15.8 & 108.8 & 5.2 \\
\hline Capital expenditure (foreign) & 77.4 & 111.9 & 157.6 & 286.9 & 456.0 & 564.8 & 826.8 & $1,095.5$ \\
\hline Change in arrears (net) & 0.0 & 0.0 & 21.0 & 16.0 & 9.0 & 81.0 & -11.7 & -84.0 \\
\hline & \multicolumn{8}{|c|}{ (In percent of GDP) } \\
\hline Current expenditure & 10.7 & 11.2 & 14.3 & 18.9 & 18.8 & 17.1 & 16.4 & 16.8 \\
\hline Wages and salaries & 4.3 & 4.3 & 6.1 & 6.2 & 6.0 & 5.8 & 5.4 & 5.3 \\
\hline Expenditure on goods and services & 2.3 & 2.5 & 2.5 & 3.8 & 3.4 & 2.6 & 2.1 & 2.0 \\
\hline Subventions & 1.4 & 1.4 & 1.5 & 3.8 & 1.9 & 1.8 & 2.1 & 1.5 \\
\hline Transfers to houșeholds & 1.3 & 1.3 & 2.1 & 1.4 & 2.8 & 2.5 & 1.7 & 1.4 \\
\hline $\begin{array}{l}\text { Interest payments } \\
\text { Capital expenditure and net lending }\end{array}$ & 7.4 & $\begin{array}{l}1.8 \\
7.8\end{array}$ & $\begin{aligned} 2.2 \\
10.3\end{aligned}$ & $\begin{array}{r}3.7 \\
11.7\end{array}$ & $\begin{array}{r}4.7 \\
14.0\end{array}$ & $\begin{array}{r}4.4 \\
14.7\end{array}$ & $\begin{aligned} 5.1 \\
13.3\end{aligned}$ & $\begin{array}{r}6.5 \\
11.6\end{array}$ \\
\hline Total expenditure and net lending & 17.8 & 19.1 & 24.6 & 30.6 & 32.8 & 31.8 & 29.7 & 28.4 \\
\hline
\end{tabular}

Source: Ministry of Finance 
Table 40. Ghana: Functional Classification of Central Government Expenditure, 1990-95 (In billions of cedis)

\begin{tabular}{|c|c|c|c|c|c|c|}
\hline & 1990 & 1991 & 1992 & 1993 & 1994 & 1995 \\
\hline Total expenditure & 254.5 & 340.3 & 498.8 & 813.5 & $1,156.3$ & $1,284.2$ \\
\hline General public services & 49.5 & 41.7 & 58.5 & 83.9 & 145.4 & 93.6 \\
\hline Defense & 9.0 & 15.2 & 23.2 & 39.5 & 30.9 & 34.5 \\
\hline Public order and safety & 0.0 & 17.2 & 21.5 & 30.8 & 23.9 & 42.9 \\
\hline Education & 64.8 & 78.8 & 118.4 & 179.2 & 207.6 & 258.7 \\
\hline Health & 25.7 & 28.7 & 39.5 & 56.6 & 58.6 & 73.6 \\
\hline Social security and welfare & 18.4 & 23.9 & 34.6 & 57.8 & 112.3 & 138.8 \\
\hline Social security and assistance & 13.8 & 21.2 & 30.9 & 51.9 & 99.0 & $\ldots$ \\
\hline Welfare & 4.6 & 2.7 & 3.7 & 5.8 & 13.3 & $\ldots$ \\
\hline Housing and community amenities & 6.6 & 7.5 & 8.6 & 12.4 & 16.8 & 48.7 \\
\hline Other community and social services & 6.9 & 7.8 & 7.0 & 10.1 & 20.6 & ... \\
\hline Economic services & 38.3 & 54.8 & 82.7 & 129.7 & 137.3 & 199.3 \\
\hline Agriculture, forestry, and fishing & 10.4 & 12.4 & 19.8 & 28.4 & 26.8 & 18.5 \\
\hline Mining, manufacturing, and construction & 2.6 & 3.2 & 7.7 & 11.0 & 18.5 & 24.6 \\
\hline Electricity, gas, steam, and water & 1.0 & 1.1 & 4.9 & 7.0 & 12.8 & 21.5 \\
\hline Roads & 16.1 & 28.2 & 42.6 & 72.2 & 75.5 & 116.7 \\
\hline Other transport and communications & 3.2 & 4.3 & 5.1 & 7.3 & $\ldots$ & $\ldots$ \\
\hline Other economic services & 4.8 & 5.6 & 2.6 & 3.8 & 3.7 & 18.0 \\
\hline Interest on public debt & 27.3 & 42.8 & 61.0 & 134.8 & 230.1 & 328.8 \\
\hline Other purpose & 0.0 & 12.6 & 16.7 & 27.9 & 108.8 & 13.9 \\
\hline \multirow[t]{2}{*}{ Special efficiency } & 8.0 & 9.3 & 27.1 & 50.8 & 64.0 & 51.4 \\
\hline & \multicolumn{5}{|c|}{ (In percent of GDP) } & \\
\hline Education & 3.4 & 3.2 & 4.2 & 4.9 & 4.2 & 3.5 \\
\hline Health & 1.3 & 1.2 & 1.4 & 1.5 & 1.2 & 1.0 \\
\hline Defense & 0.5 & 0.6 & 0.8 & 1.1 & 0.6 & 0.5 \\
\hline Social security and welfare & 1.0 & 1.0 & 1.2 & 1.6 & 2.3 & 1.9 \\
\hline Economic services & 2.0 & 2.3 & 3.0 & 3.5 & 2.6 & 1.8 \\
\hline Total expenditure & 13.2 & 14.0 & 17.8 & 22.1 & 23.2 & 16.5 \\
\hline
\end{tabular}

Source: Ministry of Finance

1/ Reported on a cash basis, excluding net lending and unallocable outlays. 
Table 41: Ghana: Distribution of Outstanding Central Government Domestic Debt, 1990-97

(In millions of cedis; end of period)

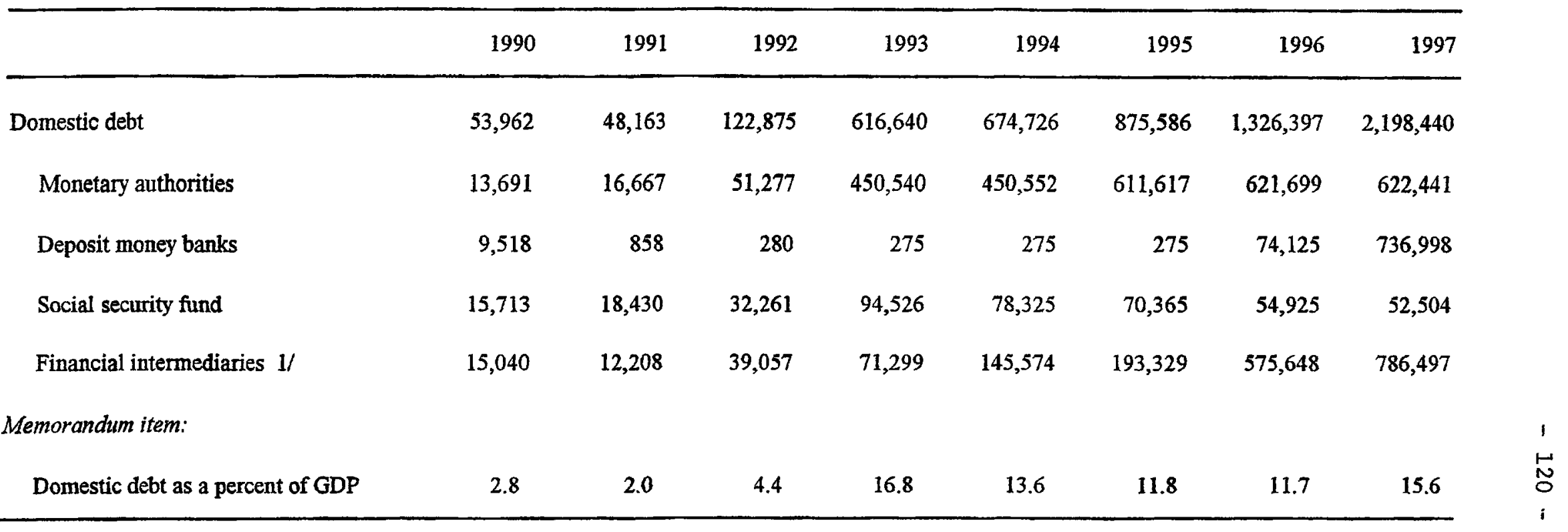

Source: Bank of Ghana

1/ Total deht held bv financial intermediaries and the nonfinancial sector. 
Table 42. Ghana: Operations of the Social Security and National Investment Trust, 1990-96 (In millions of cedis)

\begin{tabular}{|c|c|c|c|c|c|c|c|}
\hline & 1990 & 1991 & 1992 & 1993 & 1994 & 1995 & 1996 \\
\hline Contributions $1 /$ & 17,356 & 20,657 & 32,361 & 86,100 & 83,352 & 115,685 & 170,062 \\
\hline From central government & 8,045 & 10,507 & 12,085 & 54,030 & 39,820 & 54,698 & 76,272 \\
\hline From others & 9,311 & 10,149 & 20,085 & 32,070 & 43,532 & 60,988 & 93,790 \\
\hline Property income & 6,712 & 8,954 & 10,287 & 18,850 & 27,345 & 38,604 & 79,577 \\
\hline From central government stock & 5,981 & 7,208 & 7,783 & 13,473 & 20,679 & 15,283 & 29,331 \\
\hline Other & 731 & 1,746 & 2,505 & 5,377 & 6,665 & 23,321 & 50,246 \\
\hline Total revenue & 24,068 & 29,611 & 42,648 & 104,950 & 110,697 & 154,290 & 249,639 \\
\hline Administrative expenditures & 3,562 & 4,999 & 6,948 & 9,933 & 17,766 & 20,299 & 30,500 \\
\hline Wages and salaries & 1,205 & 2,307 & 3,467 & 4,957 & 9,769 & 9,314 & 12,294 \\
\hline Other & 2,358 & 2,692 & 3,481 & 4,977 & 7,896 & 10,985 & 18,206 \\
\hline Transfers to households & 957 & 787 & 1,449 & 3,321 & 81,242 & 13,545 & 20,800 \\
\hline Superannuation benefits/pensions & 857 & 502 & 550 & 704 & 1,129 & 2,004 & 2,483 \\
\hline Other $2 /$ & 100 & 285 & 899 & 2,618 & 6,995 & 11,541 & 18,317 \\
\hline Acquisition of fixed capital assets $3 /$ & 13,133 & 17,676 & 11,851 & 18,904 & 24,722 & 79,748 & 75,086 \\
\hline Total expenditure & 17,652 & 23,461 & 20,247 & 32,158 & 50,612 & 113,592 & 126,386 \\
\hline Surplus & 6,416 & 6,150 & 22,401 & 72,792 & 60,085 & 40,698 & 123,253 \\
\hline Financing & $-6,416$ & $-6,150$ & $-22,401$ & $.72,792$ & $-60,085$ & $-40,698$ & $-123,253$ \\
\hline Acquisition of central government securities & $-3,689$ & $-2,717$ & $-13,831$ & $-62,264$ & 16,200 & 7,960 & 15,440 \\
\hline Short-term deposits & -12 & $-1,650$ & $-1,889$ & 1,128 & $-14,485$ & 20,608 & 284 \\
\hline Other 4/ & $-1,471$ & 2,426 & $-1,942$ & $-10,477$ & $-67,010$ & $-132,768$ & $-8,327$ \\
\hline Unidentified & $-1,244$ & $-4,209$ & $-4,739$ & $-1,179$ & 5,210 & 63,502 & $-130,650$ \\
\hline \multicolumn{8}{|l|}{ Memorandum item: } \\
\hline Interest accruing to members' accounts & 1,378 & $\cdots$ & $\ldots$ & ... & $\cdots$ & $\cdots$ & $\cdots$ \\
\hline
\end{tabular}

Source: Social Security and National Insurance Trust.

1/ Combined employer/employee contributions from the sector shown.

2/ Emigration, death, survivor, disability, sickness, and unemployment benefits.

3/ Acquisition of offices, workers' accomodations, and real estate developments for leasing.

4/ Includes loans to the Bank for Housing and Construction and State House Corporation, as well as investment in an equipment leasing company. 
Table 43. Ghana: Summary of Financial Operations of Major State-Owned Enterprises, 1990-97

(In millions of cedis)

\begin{tabular}{|c|c|c|c|c|c|c|c|c|}
\hline & 1990 & 1991 & 1992 & 1993 & 1994 & 1995 & 1996 & 1997 \\
\hline \multicolumn{9}{|l|}{ Ilectricity Corporation of Ghana } \\
\hline Revenues & 11,081 & 14,466 & 24,458 & 46,530 & 59,831 & 103,826 & 114,704 & 139,433 \\
\hline Costs & 10,604 & 17,202 & 25,826 & 36,305 & 52,078 & 115,916 & 151,065 & 191,358 \\
\hline Of which: wages and salaries & 1,029 & $\ldots$ & $\ldots$ & 4,414 & 4,611 & 7,577 & 11,767 & 15,825 \\
\hline Gross profit & 477 & $-2,736$ & $-1,368$ & 10,225 & 7,753 & $-12,090$ & $-12,090$ & $-51,925$ \\
\hline Tax paid & $\ldots$ & $\ldots$ & $\ldots$ & $\ldots$ & $\ldots$ & $\ldots$ & $\ldots$ & $\ldots$ \\
\hline Dividend payments & $\ldots$ & $\ldots$ & $\cdots$ & $\cdots$ & $\ldots$ & $\ldots$ & $\cdots$ & $\ldots$ \\
\hline Subvention receipts & $\cdots$ & $\ldots$ & $\cdots$ & $\ldots$ & $\ldots$ & $\ldots$ & $\ldots$ & $\ldots$ \\
\hline Net lending receipts & $\ldots$ & $\ldots$ & $\ldots$ & 8,264 & 13,654 & 7,839 & 31,297 & 28,025 \\
\hline Investment & 480 & 480 & 480 & 36,789 & 31,590 & 35,594 & 80,891 & 66,851 \\
\hline Foreign financing of investment & $\cdots$ & $\cdots$ & $\cdots$ & 18,309 & 16,868 & 15,839 & 21,261 & 46,653 \\
\hline \multicolumn{9}{|l|}{ Ghana Airways Corporation } \\
\hline Revenues & 18,274 & 25,576 & 30,248 & 41,000 & 65,206 & 101,408 & 101,679 & 128,220 \\
\hline Costs & 19,138 & 25,008 & 29,982 & 43,132 & 66,402 & 102,987 & 155,261 & 206,662 \\
\hline Of which: wages and salaries & $\ldots$ & $\ldots$ & 1,138 & 3,946 & 4,675 & 6,080 & 12,959 & 16,090 \\
\hline Gross profit & 136 & 568 & 266 & $-2,132$ & $-1,196$ & $-1,579$ & $-26,666$ & $-9,905$ \\
\hline Tax paid & 264 & 60 & 70 & $\ldots$ & $\ldots$ & $\ldots$ & 30 & 57 \\
\hline Dividend payments & 336 & $\cdots$ & $\ldots$ & $\ldots$ & $\cdots$ & $\cdots$ & $\cdots$ & $\ldots$ \\
\hline Subvention receipts & $\cdots$ & $\cdots$ & ... & $\cdots$ & $\cdots$ & $\cdots$ & $\cdots$ & $\ldots$ \\
\hline Net lending receipts & $\ldots$ & $\cdots$ & $\ldots$ & $\cdots$ & $\cdots$ & $\ldots$ & $\ldots$ & $\ldots$ \\
\hline Investment & 464 & 137 & 223,886 & 180 & 199 & 91 & 91 & 91 \\
\hline Foreign financing of investment & $\ldots$ & $\ldots$ & $\ldots$ & 0 & 0 & 0 & $\mathbf{0}$ & 0 \\
\hline \multicolumn{9}{|c|}{ Ghana Cocoa Board (Cocoa Division) 1/ } \\
\hline Revenues & 100,207 & 107,599 & 63,000 & 134,760 & 184,784 & 360,806 & $\ldots$ & $\ldots$ \\
\hline Costs & 89,479 & 106,662 & 60,000 & 140,388 & 187,191 & 360,806 & $\ldots$ & $\ldots$ \\
\hline Of which: wages and salaries & $\ldots$ & $\ldots$ & 290 & $\ldots$ & 58,252 & $\ldots$ & $\cdots$ & ... \\
\hline Gross profit & 10,728 & 937 & 3,000 & $-5,629$ & $-2,408$ & $\cdots$ &.$\cdot$ & $\ldots$ \\
\hline Tax paid & $\ldots$ & $\ldots$ & 945 & ... & $\ldots$ & $\cdots$ & $\cdots$ & $\cdots$ \\
\hline Dividend payments & $\cdots$ & $\ldots$ & 100 & $\ldots$ & $\cdots$ & $\cdots$ & $\cdots$ & $\cdots$ \\
\hline Subvention receipts & $\cdots$ & $\cdots$ & $\cdots$ & $\ldots$ & $\cdots$ & $\cdots$ & $\cdots$ & $\cdots$ \\
\hline Net lending receipts & $\ldots$ & $\ldots$ & $\ldots$ & $\ldots$ & $\cdots$ & $\cdots$ & $\cdots$ & $\cdots$ \\
\hline Investment & $\ldots$ & 223,886 & 110 & 223,886 & $\cdots$ & $\cdots$ & $\cdots$ & $\cdots$ \\
\hline Foreign financing of investment & $\cdots$ & $\ldots$ & $\cdots$ & $\cdots$ & $\cdots$ & $\cdots$ & $\cdots$ & $\cdots$ \\
\hline \multicolumn{9}{|l|}{ Ghana Oil Company Limited } \\
\hline Revenues & 29,568 & 48,208 & $\ldots$ & 76,107 & 95,006 & 110,633 & 156,284 & 217,170 \\
\hline Costs & 28,777 & 46,756 & $\ldots$ & 76,085 & 94,844 & 110,406 & 155,959 & 216,839 \\
\hline Of which: wages and salaries & 233 & $\ldots$ & & 964 & 1,095 & 1,395 & 1,921 & 3,141 \\
\hline Gross profit & 791 & 1,452 & $\ldots$ & 325 & 571 & 695 & 1,218 & 1,356 \\
\hline Tax paid & 224 & 378 & $\ldots$ & 309 & 406 & 472 & 673 & 728 \\
\hline Dividend payments & 15 & 100 & $\ldots$ & 0 & 104 & 104 & 142 & 190 \\
\hline Subvention receipts & $\ldots$ & $\ldots$ & & $\ldots$ & $\cdots$ & $\cdots$ & $\cdots$ & $\cdots$ \\
\hline Net lending receipts & $\ldots$ & $\cdots$ & & $\ldots$ & $\ldots$ & $\cdots$ & $\cdots$ & $\cdots$ \\
\hline Investment & 110 & 110 & & 109 & 109 & 110 & 110 & 110 \\
\hline Foreign financing of investment & $\ldots$ & $\ldots$ & $\cdots$ & 20,885 & 13,840 & 14,201 & 16,626 & 27,934 \\
\hline
\end{tabular}

Source: Ministry of Finance 
Table 43. Ghana: Summary of Financial Operations of Major State-Owned Enterprises, 1990-96 (continued)

(In millions of cedis)

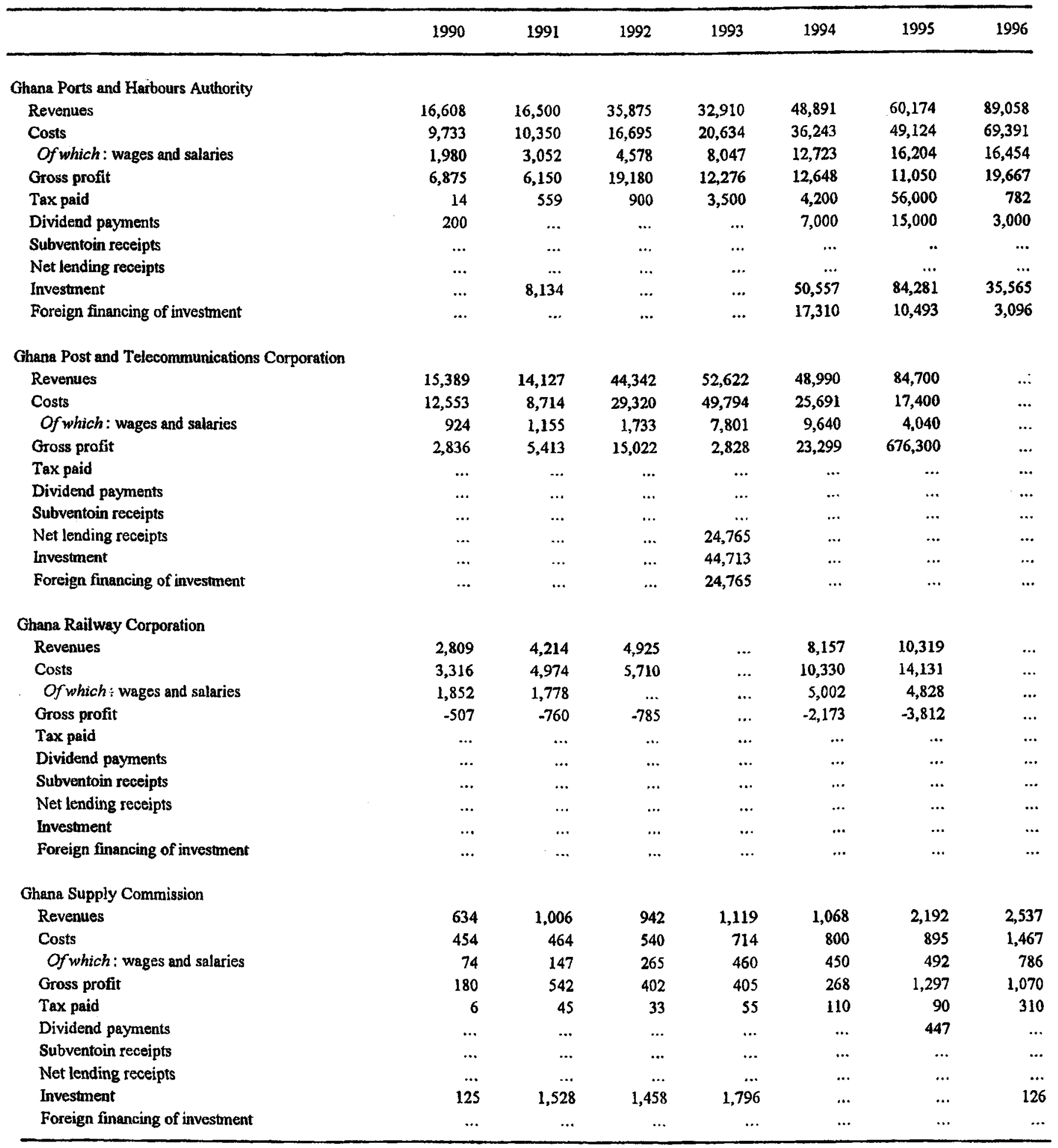


Table 43. Ghana: Summary of Financial Operations of Major State-Owned Enterprises, $1990-96$ (continued)

(In millions of cedis)

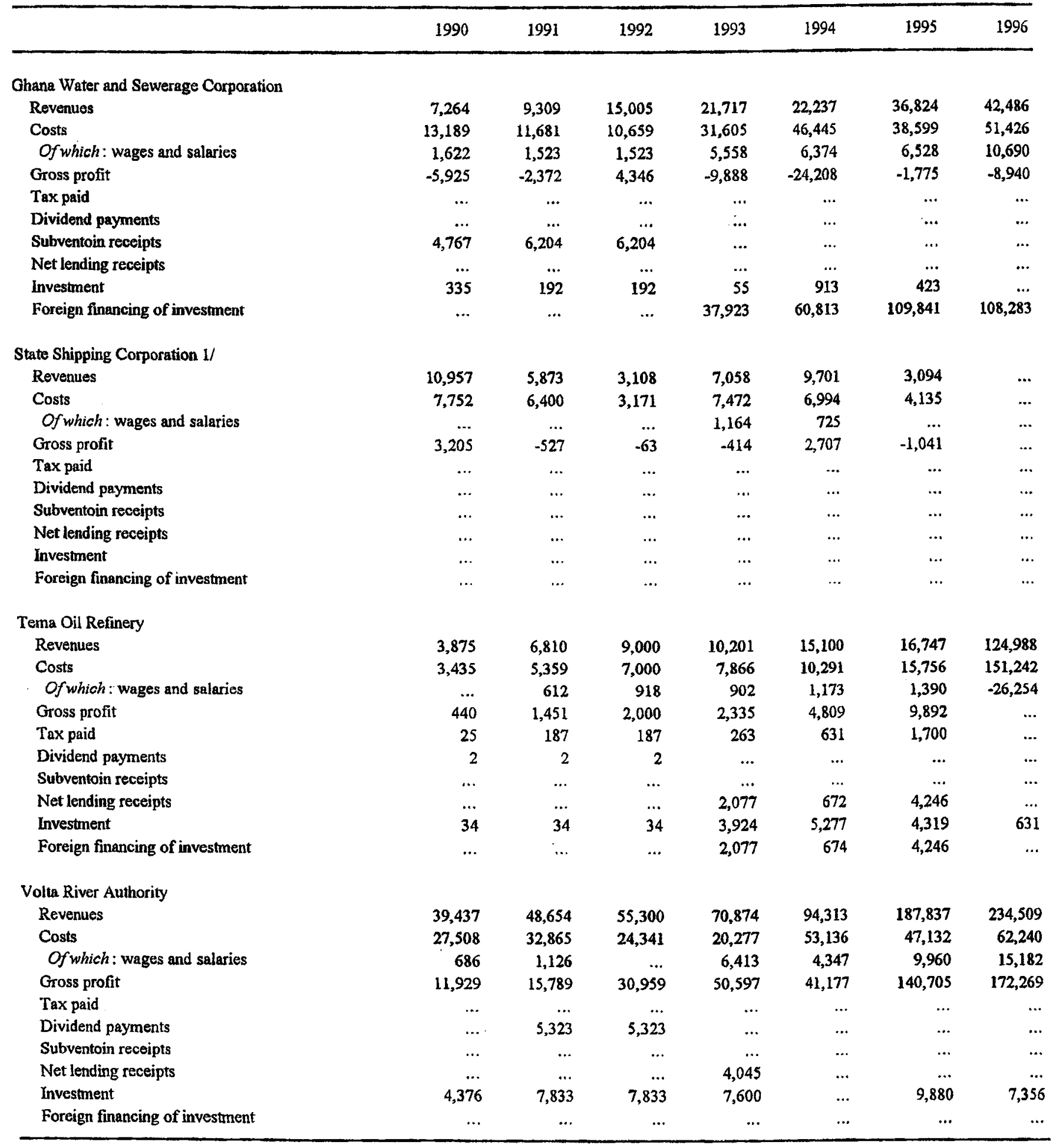

1/ Liquidated in 1996 
Table 43. Ghana: Summary of Financial Operations of Major State-Owned Enterprises, 1990-96 (concluded)

(In millions of cedis)

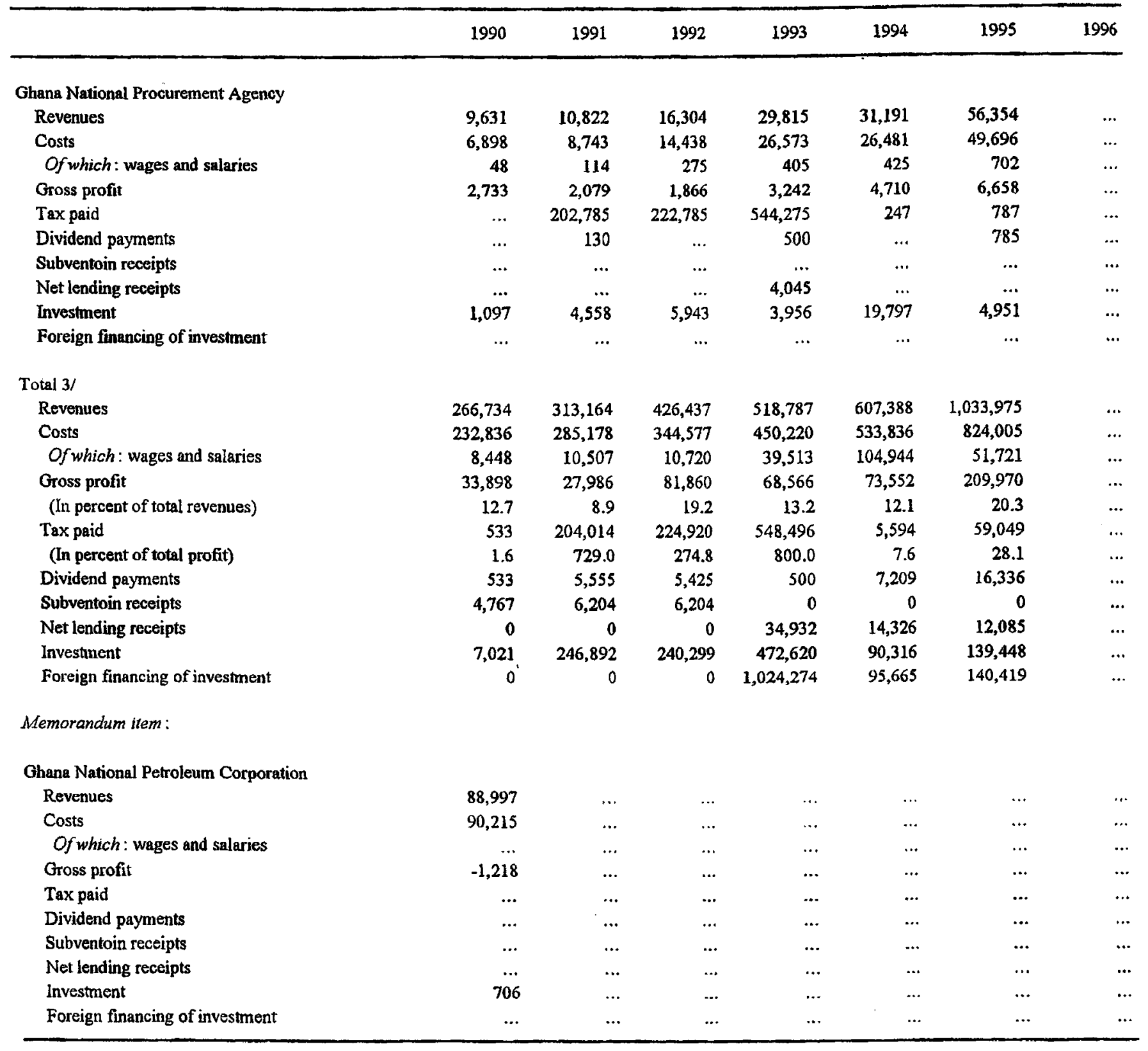

Source: State Enterprise Commission; and staff estimates.

1/ Cocoa Board figures are staff estimates based on annual crop year accounts ending September 30.

2/ Cocoa Board revenues are net of export duty paid on cocoa.

3/ Excludes Ghana Railway Corporation in 1993 and Ghana Airways Corporation in 1994. 
Table 44. Ghana: Public Investment Program, 1994-97 1/ (In millions of cedis)

\begin{tabular}{|c|c|c|c|c|c|c|c|c|}
\hline & \multicolumn{2}{|c|}{$\begin{array}{c}1994 \\
\text { Actual } \\
\end{array}$} & \multicolumn{2}{|c|}{$\begin{array}{c}1995 \\
\text { Actual } \\
\end{array}$} & \multicolumn{2}{|c|}{$\begin{array}{c}1996 \\
\text { Actual } \\
\end{array}$} & \multicolumn{2}{|c|}{$\frac{1997}{\text { Provisional }}$} \\
\hline & $\begin{array}{c}\text { Investment } \\
\text { by sector }\end{array}$ & $\begin{array}{l}\text { Percentage } \\
\text { distribution }\end{array}$ & $\begin{array}{r}\text { Investment } \\
\text { by sector }\end{array}$ & $\begin{array}{r}\text { Percentage } \\
\text { distribution }\end{array}$ & $\begin{array}{r}\text { Investment } \\
\text { by sector }\end{array}$ & $\begin{array}{l}\text { Percentage } \\
\text { distribution }\end{array}$ & $\begin{array}{r}\text { Investment } \\
\text { by sector }\end{array}$ & $\begin{array}{r}\text { Percentage } \\
\text { distribution }\end{array}$ \\
\hline Directly productive sectors & 43.6 & 8.2 & 67.8 & 8.8 & 98.8 & 6.0 & 160.3 & 15.2 \\
\hline Agriculture & 9.4 & 1.8 & 50.5 & 6.5 & 69.4 & 4.2 & 138.1 & 13.1 \\
\hline Industry & 1.1 & 0.2 & 1.2 & 0.2 & 5.8 & 0.4 & 11.4 & 1.1 \\
\hline Mining and forestry & 33.1 & 6.3 & 16.1 & 2.1 & 23.6 & 1.4 & 10.8 & 1.0 \\
\hline Economic infrastructure & 383.6 & 72.5 & 549.8 & 71.3 & $1,103.2$ & 67.0 & 625.9 & 59.5 \\
\hline Water & 96.3 & 18.2 & 99.0 & 12.8 & 91.3 & 5.5 & 15.3 & 1.5 \\
\hline Transport and communication & 65.2 & 12.3 & 59.4 & 7.7 & 72.4 & 4.4 & 18.4 & 1.7 \\
\hline Energy & 57.6 & 10.9 & 154.3 & 20.0 & 362.8 & 22.0 & 302.8 & 28.8 \\
\hline Roads and highways & 150.5 & 28.5 & 222.7 & 28.9 & 521.6 & 31.7 & 275.9 & 26.2 \\
\hline Works and housing & 14.1 & 2.7 & 14.5 & 1.9 & 55.1 & 3.3 & 13.5 & 1.3 \\
\hline Social and administrative sectors & 98.7 & 18.7 & 152.5 & 19.8 & 440.8 & 26.7 & 264.0 & 25.1 \\
\hline Education & 58.2 & 11.0 & 83.3 & 10.8 & 80.3 & 4.9 & 72.9 & 6.9 \\
\hline Health & 26.8 & 5.1 & 48.5 & 6.3 & 139.8 & 8.5 & 170.6 & 16.2 \\
\hline Local gov't and community development & 2.5 & 0.5 & 9.3 & 1.2 & 188.3 & 11.4 & 20.5 & 1.9 \\
\hline PAMSCAD $2 /$ & 0.4 & 0.1 & 0.5 & 0.1 & 0.3 & 0.0 & 0.0 & 0.0 \\
\hline Other & 10.7 & 2.0 & 10.9 & 1.4 & 32.1 & 1.9 & $\ldots$ & $\ldots$ \\
\hline Culture & 2.9 & 0.5 & 1.5 & 0.2 & 5.0 & 0.3 & 2.5 & 0.2 \\
\hline Total & 528.8 & 100.0 & 771.6 & 100.0 & $1,647.8$ & 100.0 & $1,052.7$ & 100.0 \\
\hline
\end{tabular}

Source: Data provided by the Ghanaian authorities.

${ }^{1}$ Formulated on the basis of a $1600 /$ US $\$ 1$ exchange rate (end-April 1996) for foreign sources of funding.

${ }^{2}$ Program of Actions to Mitigate the Social Costs of Adjustment. 
Table 45. Ghana: Monetary Survey, 1994-98

(In billions of cedis, unless otherwise specified; end of period)

\begin{tabular}{|c|c|c|c|c|c|}
\hline & $\frac{1994}{\text { Dec. }}$ & $\frac{1995}{\text { Dec. }}$ & $\frac{1996}{\text { Dec. }}$ & $\frac{1997}{\text { Dec. }}$ & $\frac{1998}{\text { June }}$ \\
\hline \multicolumn{6}{|l|}{ Bank of Ghana } \\
\hline $\begin{array}{l}\text { Net foreign assets } \\
\text { (in millions of US, dollars) }\end{array}$ & -225 & 51 & 28 & 92 & 147 \\
\hline Net domestic assets & $\begin{array}{r}-214 \\
686\end{array}$ & $\begin{array}{r}35 \\
572\end{array}$ & $\begin{array}{r}16 \\
871\end{array}$ & $\begin{array}{r}41 \\
1111\end{array}$ & $\begin{array}{r}63 \\
974\end{array}$ \\
\hline Claims on government (net) & 175 & 114 & 289 & 134 & -167 \\
\hline Claims on deposit money banks & 7 & 8 & 9 & 33 & 11 \\
\hline Claims on nonbank sector (including public enterprises) & 149 & 189 & 146 & 76 & 13 \\
\hline Bank of Ghana bills (-) & -479 & -657 & -518 & -195 & .26 \\
\hline Other items net; assets + & 836 & 917 & 945 & 1062 & 1143 \\
\hline Reserve money (RM) & 461 & 623 & 899 & 1203 & 1122 \\
\hline Currency outside banks & 369 & 546 & 721 & 982 & 837 \\
\hline Bank reserves & 89 & 69 & 169 & 212 & 273 \\
\hline Nonbank deposits & 4 & 8 & 10 & 9 & 13 \\
\hline \multicolumn{6}{|l|}{ Deposit money banks $1 /$} \\
\hline Net foreign assets & 393 & 409 & 610 & 720 & 535 \\
\hline Reserves & 89 & 107 & 201 & 219 & 258 \\
\hline Cash & 23 & 39 & 46 & 58 & 48 \\
\hline Deposits from Bank of Ghana & 65 & 67 & 154 & 162 & 210 \\
\hline Bank of Ghana bills & 369 & 564 & 475 & 178 & 13 \\
\hline Credit from Bank of Ghana & -20 & -18 & -29 & -44 & -50 \\
\hline Domestic credit & 234 & 362 & 699 & 1936 & 2759 \\
\hline Claims on government (net) & -69 & -76 & -39 & 635 & 1120 \\
\hline Claims & 0 & 0 & 90 & 681 & 1175 \\
\hline Deposits & 69 & 76 & 129 & 46 & 55 \\
\hline Claims on private sector $2 l$ & 303 & 438 & 738 & 1301 & 1638 \\
\hline Of which: In foreign currency & 13 & 47 & 90 & 331 & 508 \\
\hline Other items net; assets + & -267 & -331 & 329 & -679 & -866 \\
\hline Total deposits & 798 & 1093 & 1627 & 2330 & 2648 \\
\hline \multicolumn{6}{|l|}{ Monetary Survey } \\
\hline Net foreign assets & 168 & 460 & 638 & 812 & 682 \\
\hline Net domestic assets & 1003 & 1188 & 1719 & 2508 & 2816 \\
\hline Domestic credit & 557 & 666 & 1134 & 2146 & 2605 \\
\hline Claims on government (net) & 106 & 39 & 249 & 769 & 954 \\
\hline Claims on private sector $1 /$ & 452 & 627 & 885 & 1377 & 1651 \\
\hline Bank of Ghana bills held by nonbanks & -37 & -33 & -37 & -17 & -13 \\
\hline Other items net; assets + & 483 & 555 & 622 & 379 & 224 \\
\hline Broad money (M2) 3/ & 1170 & 1648 & 2358 & 3320 & 3498 \\
\hline Currrency & 369 & 546 & 721 & 982 & 837 \\
\hline Deposits & 802 & 1101 & 1637 & 2339 & 2661 \\
\hline Of which: foreign currency deposits & 203 & 318 & 531 & 729 & 721 \\
\hline \multicolumn{6}{|l|}{ Memorandum Item: } \\
\hline Broad money (12-month change in percnet) & 53.00 & 40.80 & 39.70 & 40.80 & 28.10 \\
\hline Excluding foreign currency deposits (cedi M2) & 46.20 & 37.40 & 37.40 & 41.90 & 34.20 \\
\hline Reserve money (12-month change in percent) & 78.90 & 35.10 & 44.30 & 33.80 & 29.30 \\
\hline Currency/M2 ratio & 0.32 & 0.33 & 0.31 & 0.30 & 0.24 \\
\hline Velocity (GDP/average of M2) & 5.50 & 5.59 & 5.56 & 4.95 & \\
\hline Reserve money multiplier (M2/RM) & 2.54 & 2.64 & 2.62 & 2.76 & 3.12 \\
\hline
\end{tabular}

Sources: Ghanaian authorities; and Fund staff estimates and projections.

1/ From December 1996, the coverage was increased from 11 to 17 banks.

2/ Including public enterprises

3/ Newly defined broad money includes all foreign currency deposits held in commercial banks. 
Table 46. Ghana: Monetary Authorities, 1994-1998

(In billions of cedis)

\begin{tabular}{|c|c|c|c|c|c|}
\hline & 1994 & 1995 & 1996 & 1997 & 1998 \\
\hline & $\overline{\text { Dec. }}$ & $\overline{\text { Dec. }}$ & Dec. & Dec. & June \\
\hline Net foreign assets & -225.3 & 50.9 & 28.3 & 92.5 & 147.3 \\
\hline (In millions of U.S. dollars) & -214.0 & 35.1 & 16.2 & 41.1 & 63.4 \\
\hline Net domestic assets & 686.5 & 572.2 & .870 .9 & $1,110.6$ & 974.3 \\
\hline Claims on government (net) & 174.5 & 114.4 & 288.7 & 133.7 & -166.8 \\
\hline Claims on government & 492.6 & 608.7 & 613.2 & 772.1 & 649.0 \\
\hline Treasury bills & 2.9 & 4.2 & 10.3 & 13.4 & 42.7 \\
\hline Ghana stocks & 12.8 & 17.1 & 12.1 & 14.3 & 15.6 \\
\hline Government overdrafts & 42.3 & 152.9 & 0.0 & 0.0 & 0.0 \\
\hline Long-term government stocks & 434.6 & 434.6 & 590.7 & 590.7 & 590.7 \\
\hline Government deposits & 318.1 & 494.3 & 324.5 & 484.7 & 815.8 \\
\hline Claims on deposit money banks & 6.7 & 8.3 & 9.4 & 33.0 & 11.1 \\
\hline \multicolumn{6}{|l|}{ Claims on nonbank secctor } \\
\hline (including public enterprises) & 148.8 & 189.1 & 146.5 & 76.5 & 12.8 \\
\hline Claims on public enterprises & 148.8 & 151.9 & 135.8 & 71.9 & 6.3 \\
\hline $\begin{array}{l}\text { Of which: claims on Cocoa Board } \\
\text { claims on Ghana National }\end{array}$ & 0.2 & 0.0 & 0.0 & 0.0 & 0.0 \\
\hline Petroleum Corporation & $\ldots$ & $\ldots$ & 128.0 & 62.6 & 0.0 \\
\hline Claims on private sector & 0.0 & 0.0 & 0.0 & 0.0 & 0.0 \\
\hline Claims on other financial institutions & 0.0 & 37.2 & 10.7 & 4.6 & 6.5 \\
\hline Bank of Ghana bills (-) & -479.5 & -656.8 & -518.2 & -194.9 & -25.7 \\
\hline Held by banks & -442.7 & -623.9 & -481.5 & -178.4 & -13.1 \\
\hline Held by nonbanks & -36.8 & -32.9 & -36.7 & -16.5 & -12.6 \\
\hline Other items net (assets + ) & 836.1 & 917.1 & 944.6 & $1,062.3$ & $1,143.0$ \\
\hline Reserve money & 461.3 & 623.1 & 899.2 & $1,203.1$ & $1,121.6$ \\
\hline Currency outside banks & 368.8 & 546.3 & 720.0 & 981.8 & 836.5 \\
\hline Bank reserves & 88.6 & 68.9 & 168.6 & 212.4 & 272.5 \\
\hline Cash & 23.3 & 39.2 & 43.4 & 57.5 & 48.3 \\
\hline Deposits & 65.3 & 29.7 & 125.4 & 154.8 & 224.2 \\
\hline Required reserves & 29.7 & 38.8 & 109.6 & 186.4 & 211.9 \\
\hline Excess reserves & 35.5 & -9.0 & 15.7 & -35.6 & 12.3 \\
\hline Nonbank deposits & 3.9 & 7.9 & 9.6 & 8.9 & 12.6 \\
\hline \multicolumn{6}{|l|}{ Memorandum item: } \\
\hline Exchange rate (cedis/US\$) & $1,052.6$ & $1,449.3$ & $1,740.4$ & $2,250.4$ & $2,323.0$ \\
\hline
\end{tabular}

Source: Bank of Ghana 
Table 47. Ghana: Deposit Money Banks, 1994-1998 1/

(In billions of cedis)

\begin{tabular}{|c|c|c|c|c|c|}
\hline & 1994 & 1995 & 1996 & 1997 & 1998 \\
\hline & Dec. & Dec. & Dec. & Dec. & \\
\hline Net foreign assets & 392.6 & 409.0 & 610.1 & 719.7 & 534.5 \\
\hline (In millions of US dollars) & 373.0 & 282.2 & 350.5 & 319.8 & 230.1 \\
\hline Reserves & 88.7 & 106.7 & 201.3 & 219.2 & 258.0 \\
\hline Cash & 23.3 & 39.2 & 46.3 & 57.6 & 48.3 \\
\hline Deposits with Bank of Ghana & 65.4 & 67.5 & 154.9 & 161.7 & 209.7 \\
\hline Bank of Ghana bills & 369.4 & 564.1 & 475.3 & 178.4 & 13.1 \\
\hline Credit from Bank of Ghana & -19.8 & -17.6 & -29.4 & -44.4 & -50.3 \\
\hline Domestic credit & 233.9 & 362.1 & 698.9 & $1,935.8$ & $2,758.7$ \\
\hline Claims on Government (net) & -68.9 & -75.7 & 39.5 & 635.1 & $1,120.4$ \\
\hline Claims & 0.3 & 0.3 & 89.2 & 681.1 & $1,175.4$ \\
\hline Deposits & 69.2 & 76.0 & 128.7 & 46.0 & 55.0 \\
\hline \multicolumn{6}{|l|}{ Claims on nonbank private sector } \\
\hline (including public enterprise) & 302.8 & 437.8 & 738.3 & $1,300.6$ & $1,638.3$ \\
\hline Claims on public enterprises & 21.8 & 36.4 & 48.3 & 56.7 & 226.1 \\
\hline Cocoa financing & 7.8 & 8.1 & 9.1 & 87.3 & 25.4 \\
\hline Credit to private sector & 273.3 & 393.3 & 680.9 & $1,156.6$ & $1,386.8$ \\
\hline of which : In foreign currency & 13.1 & 46.7 & 90.0 & 331.0 & 508.0 \\
\hline (in millions of U.S. dollars) & $\ldots$ & $\ldots$ & 51.7 & 147.1 & 218.7 \\
\hline Other items net (assets + ) & -267.1 & -330.8 & 328.8 & -678.9 & -865.5 \\
\hline Total deposits & 797.8 & $1,093.3$ & $1,627.3$ & $2,329.7$ & $2,648.5$ \\
\hline Demand deposits & 320.9 & 371.1 & 502.2 & 776.5 & 934.4 \\
\hline Savings and time deposits & 273.8 & 404.3 & 594.0 & 823.8 & 992.8 \\
\hline Foreign currency deposits & 203.1 & 318.0 & 531.1 & 729.3 & 721.3 \\
\hline (in millions of U.S. dollars) & 192.9 & 219.4 & 305.2 & 324.1 & 310.5 \\
\hline \multicolumn{6}{|l|}{ Memorandum item: } \\
\hline Exchange rate (cedis/US\$) & $1,052.6$ & $1,449.3$ & $1,740.4$ & $2,250.4$ & $2,323.0$ \\
\hline
\end{tabular}

Source: Bank of Ghana

1/ In 1996, the coverage was increased from 11 to 17 banks. 
Table 48. Ghana: Distribution of Bank Loans and Advances

to Public Institutions and the Private Sector, 1991-97

\begin{tabular}{|c|c|c|c|c|c|c|c|}
\hline & 1991 & 1992 & 1993 & 1994 & 1995 & 1996 & 1997 \\
\hline & \multicolumn{7}{|c|}{ (In billions of cedis; end of period) } \\
\hline Agriculture, forestry & & & & & & & \\
\hline and fishing $1 /$ & 12.4 & 14.7 & 17.3 & 24.4 & 42.1 & 79.7 & 154.2 \\
\hline Mining and quarrying & 1.2 & 2.5 & 3.2 & 5.4 & 6.5 & 29.0 & 66.3 \\
\hline Manufacturing & 23.0 & 37.9 & 51.2 & 86.6 & 129.3 & 227.1 & 295.8 \\
\hline Construction & 14.4 & 27.0 & 32.8 & 43.6 & 50.8 & 72.2 & 131.0 \\
\hline Electricity, gas, and water & 1.6 & 3.4 & 5.8 & 6.2 & 6.3 & 14.3 & 20.8 \\
\hline Commerce & 25.9 & 44.5 & 66.1 & 89.3 & 137.2 & 199.1 & 432.6 \\
\hline Imports & 5.9 & 12.5 & 14.9 & 18.9 & 23.6 & 34.5 & 58.8 \\
\hline Exports & 4.7 & 9.0 & 12.3 & 20.0 & 44.6 & 58.5 & 51.4 \\
\hline Domestic 2/ & 15.2 & 23.0 & 38.8 & 50.4 & 69.0 & 106.1 & 322.4 \\
\hline \multicolumn{8}{|l|}{ Transport, storage, and } \\
\hline communications & 5.3 & 5.6 & 6.9 & 8.3 & 8.0 & 13.7 & 21.5 \\
\hline Services & 7.2 & 11.0 & 13.8 & 18.6 & 33.2 & 68.3 & 121.2 \\
\hline Miscellaneous & 2.9 & 4.6 & 10.1 & 12.9 & 19.2 & 29.0 & 50.5 \\
\hline \multirow[t]{2}{*}{ Total } & 93.9 & 151.3 & 207.1 & 295.2 & 432.5 & 732.4 & $1,293.8$ \\
\hline & \multicolumn{7}{|c|}{ (Shares in total; in percent) } \\
\hline $\begin{array}{l}\text { Agriculture, forestry, } \\
\text { and fishing } 1 /\end{array}$ & 13.2 & 9.7 & 8.4 & 8.3 & 9.7 & 10.9 & 11.9 \\
\hline Mining and quarrying & 1.3 & 1.6 & 1.5 & 1.8 & 1.5 & 4.0 & 5.1 \\
\hline Manufacturing & 24.5 & 25.1 & 24.7 & 29.3 & 29.9 & 31.0 & 22.9 \\
\hline Construction & 15.3 & 17.9 & 15.8 & 14.8 & 11.7 & 9.9 & 10.1 \\
\hline Electricity, gas, and water & 1.7 & 2.3 & 2.8 & 2.1 & 1.5 & 2.0 & 1.6 \\
\hline Commerce & 27.6 & 29.4 & 31.9 & 30.3 & 31.7 & 27.2 & 33.4 \\
\hline Imports & 6.3 & 8.3 & 7.2 & 6.4 & 5.5 & 4.7 & 4.5 \\
\hline Exports & 5.0 & 5.9 & 5.9 & 6.8 & 10.3 & 8.0 & 4.0 \\
\hline Domestic & 16.2 & 15.2 & 18.7 & 17.1 & 16.0 & 14.5 & 24.9 \\
\hline \multicolumn{8}{|l|}{ Transport, storage, and } \\
\hline communications & 5.7 & 3.7 & 3.3 & 2.8 & 1.8 & 1.9 & 1.7 \\
\hline Services & 7.6 & 7.3 & 6.7 & 6.3 & 7.7 & 9.3 & 9.4 \\
\hline Miscellaneous & 3.1 & 3.0 & 4.9 & 4.4 & 4.4 & 4.0 & 3.9 \\
\hline \multirow[t]{2}{*}{ Total } & 100.0 & 100.0 & 100.0 & 100.0 & 100.0 & 100.0 & 100.0 \\
\hline & \multicolumn{7}{|c|}{ (Annual percentage changes) } \\
\hline $\begin{array}{l}\text { Agriculture, forestry, } \\
\text { and fishing } 1 /\end{array}$ & 2.2 & 18.4 & 17.3 & 41.5 & 72.4 & 89.2 & 93.4 \\
\hline Mining and quarrying & 12.6 & 111.5 & 28.8 & 69.5 & 21.1 & 345.8 & 128.6 \\
\hline Manufacturing & 0.6 & 64.8 & 34.9 & 69.1 & 49.3 & 75.7 & 30.2 \\
\hline Construction & 35.9 & 87.9 & 21.2 & 33.0 & 16.5 & 42.2 & 81.4 \\
\hline Electricity, gas, and water & 451.9 & 116.7 & 70.5 & 5.5 & 1.6 & 128.4 & 45.7 \\
\hline Commerce & 61.6 & 71.8 & 48.6 & 35.2 & 53.6 & 45.2 & 117.3 \\
\hline Imports & 43.5 & 110.7 & 19.2 & 26.6 & 24.7 & 46.5 & 70.4 \\
\hline Exports & 40.2 & 89.2 & 37.8 & 62.0 & 122.9 & 31.2 & -12.1 \\
\hline Domestic $2 /$ & 78.9 & 51.2 & 68.8 & 29.9 & 36.9 & 53.8 & 203.8 \\
\hline \multicolumn{8}{|l|}{ Transport, storage, and } \\
\hline communications & 20.2 & 5.1 & 22.7 & 21.3 & -3.4 & 69.8 & 57.1 \\
\hline Services & 13.5 & 54.0 & 24.7 & 35.2 & 78.7 & 105.6 & 77.4 \\
\hline Miscellaneous & 9.2 & 57.8 & 120.3 & 27.1 & 48.9 & 51.1 & 74.1 \\
\hline Total & 22.9 & 61.1 & 36.9 & 42.6 & 46.5 & 69.3 & 76.7 \\
\hline
\end{tabular}

Source: Bank of Ghana.

1/ Excludes loans and advances to the Cocoa Board. 2/ Includes loans and advances to the Cocoa Board. 


$$
-131-
$$

Table 49. Ghana: Reserve Ratios of Commeroial Banks, 1992-98; June (End-of-period figures, in billions of cedis)

\begin{tabular}{|c|c|c|c|c|c|c|c|c|c|c|c|}
\hline & \multirow{4}{*}{$\begin{array}{l}\text { Deposits } \\
\text { subject to } \\
\text { reserve } \\
\text { ratios }\end{array}$} & \multicolumn{3}{|c|}{ Actual reserves } & \multicolumn{7}{|c|}{ Reserve ratios } \\
\hline & & \multirow[t]{3}{*}{ Cash } & \multirow{3}{*}{$\begin{array}{l}\text { Other } \\
\text { assets } 1 /\end{array}$} & \multirow[t]{3}{*}{ Total } & \multicolumn{3}{|c|}{ Cash } & \multicolumn{2}{|c|}{ Other assets $1 /$} & \multicolumn{2}{|c|}{ Total } \\
\hline & & & & & \multicolumn{2}{|c|}{ Minimum } & \multirow{2}{*}{ Actual } & \multirow[t]{2}{*}{ Minimum } & \multirow[t]{2}{*}{ Actual } & \multirow[t]{2}{*}{ Actual } & \multirow[t]{2}{*}{ Excess } \\
\hline & & & & & Demand $2 /$ & Time $3 /$ & & & & & \\
\hline \multicolumn{12}{|l|}{1992} \\
\hline March & 260.6 & 51.9 & 98.9 & 150.7 & 18.0 & 18.0 & 19.9 & 24.0 & 37.9 & 57.8 & 15.8 \\
\hline June & 280.4 & 58.4 & 113.4 & 181.8 & 18.0 & 18.0 & 20.8 & 24.0 & 40.4 & 61.2 & 24.9 \\
\hline September & 304.6 & 60.7 & 136.2 & 196.9 & 18.0 & 18.0 & 19.9 & 24.0 & 44.7 & 64.6 & 23.5 \\
\hline December & 344.3 & 69.9 & 140.8 & 218.7 & 18.0 & 18.0 & 20.3 & 24.0 & 40.9 & 63.5 & 21.5 \\
\hline \multicolumn{12}{|l|}{1993} \\
\hline March & 350.1 & 57.8 & 181.2 & 239.0 & 10.0 & 10.0 & 16.5 & 32.0 & 51.8 & 68.3 & 26.3 \\
\hline June & 362.4 & 45.2 & 209.3 & 254.5 & 10.0 & 10.0 & 12.5 & 47.0 & 57.7 & 70.2 & 13.2 \\
\hline September & 381.9 & 46.3 & 220.6 & 267.0 & 10.0 & 10.0 & 12.1 & 47.0 & 57.8 & 69.9 & 12.9 \\
\hline December & 418.7 & 38.7 & 264.4 & 303.1 & 5.0 & 5.0 & 9.3 & 52.0 & 63.1 & 72.4 & 15.4 \\
\hline \multicolumn{12}{|l|}{1994} \\
\hline March & 440.1 & 35.5 & 297.9 & 333.4 & 5.0 & 5.0 & 7.9 & 52.0 & 66.5 & 74.4 & 17.4 \\
\hline June & 507.2 & 42.8 & 341.7 & 384.5 & 5.0 & 5.0 & 8.4 & 52.0 & 67.4 & 75.8 & 18.8 \\
\hline September & 546.0 & 47.1 & 364.4 & 411.5 & 5.0 & 5.0 & 8.6 & 52.0 & 66.7 & 75.4 & 10.4 \\
\hline December & 614.4 & 53.6 & 437.7 & 401.4 & 5.0 & 5.0 & 8.7 & 52.0 & 71.2 & 80.0 & 23.0 \\
\hline \multicolumn{12}{|l|}{1995} \\
\hline March & 654.1 & 60.0 & 437.7 & 505.7 & 5.0 & 5.0 & 10.4 & 52.0 & 66.9 & 77.3 & 20.3 \\
\hline June & 720.2 & 72.3 & 447.6 & 519.9 & 5.0 & 6.0 & 10.0 & 52.0 & 62.1 & 72.2 & 15.2 \\
\hline September & 836.4 & 78.1 & 427.4 & 505.5 & 5.0 & 5.0 & 9.3 & $\$ 2.0$ & 51.1 & 60.4 & 3.4 \\
\hline December & 954.4 & 109.1 & 468.2 & 577.3 & 5.0 & 5.0 & 11.4 & 52.0 & 49.1 & 60.5 & 3.5 \\
\hline \multicolumn{12}{|l|}{1996} \\
\hline March & 996.9 & 100.1 & 500.0 & 600.1 & 5.0 & $\ldots$ & 10.0 & 52.0 & 50.2 & 60.2 & 3.2 \\
\hline June 4/ & 1121.0 & 97.6 & 707.0 & 803.5 & 5.0 & $\ldots$ & 8.7 & $\$ 2.0$ & 63.0 & 53.9 & -3.1 \\
\hline September & 1221.6 & 110.8 & 542.0 & 652.8 & 5.0 & $\ldots$ & 9.1 & 52.0 & 44.4 & 53.4 & -3.6 \\
\hline December & 1311.8 & 152.8 & 626.3 & 779.0 & 10.0 & $\ldots$ & 11.6 & $\$ 2.0$ & 47.7 & 62.5 & 5.5 \\
\hline \multicolumn{12}{|l|}{1997} \\
\hline March & 1376.4 & 180.2 & 722.3 & 902.5 & 5.0 & 5.0 & 13.1 & 47.0 & 52.5 & 65.6 & 13.6 \\
\hline June & 2154.7 & 172.6 & 1161.1 & 1333.7 & 4.0 & 4.0 & 8.0 & 35.0 & 53.9 & 61.9 & 22.9 \\
\hline September & 2264.6 & 197.9 & 973.8 & 1171.7 & 4.0 & 4.0 & 8.0 & 35.0 & 43.0 & 51.7 & 12.7 \\
\hline December & 2319.4 & 273.5 & 1120.4 & 1393.9 & 4.0 & 4.0 & 11.8 & 35.0 & 48.3 & 60.1 & 21.1 \\
\hline \multicolumn{12}{|l|}{1998} \\
\hline March & 2526.2 & 250.8 & 1325.9 & 1576.8 & 4.0 & 4.0 & 9.9 & 35.0 & 52.5 & 62.4 & 23.4 \\
\hline June & 2679.7 & 281.9 & 1419.9 & 1701.8 & 4.0 & 4.0 & 10.5 & 35.0 & 53.0 & 63.5 & 24.5 \\
\hline
\end{tabular}

Sources: Bank of Ghana; and staff estimates.

1/ Comprises treasury bills, government securities, Bank of Ghana bills, cocoa bills, and grain cotton bills, and export finance bills.

2/ Cash reserve requirements on demand deposits.

3/ Cash reserve requirements on time and savings deposits.

4/ From June 1996, First Atlantice and Metro Allied have been added. 
Table 50, Ghana: Interest Rate Structure of Banks, September 1995-June 1998

(In percent per annum)

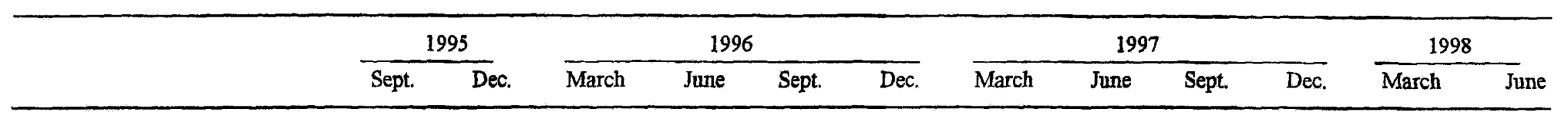

Money market rates $1 /$

Bank of Ghana instruments

91-day
180-day
1-year
2-year

Treasury bills (91-day)

Bank of Ghana rediscount rate

\begin{tabular}{|c|c|c|c|c|c|c|c|c|c|c|c|}
\hline 39.00 & 40.50 & 40.99 & 41.46 & 42.59 & 42.76 & 42.80 & 42.80 & 42.80 & 42.48 & 39.50 & 35.24 \\
\hline 32.00 & 33.00 & 33.47 & 35.83 & 35.83 & 36.00 & 38.60 & 38.60 & 38.60 & 38.60 & 38.60 & 38.60 \\
\hline 36.00 & 39.00 & 39.36 & 39.86 & 40.30 & 42.52 & 42.79 & 42.79 & 42.79 & 42.80 & 39.50 & 35.24 \\
\hline 33.00 & 33.00 & 33.00 & 33.50 & 33.50 & 33.50 & 33.50 & 33.50 & 33.50 & 33.50 & 33.50 & 33.50 \\
\hline 39.00 & 40.50 & 40.99 & 41.63 & 42.59 & 42.76 & 42.80 & 42.80 & 42.80 & 42.48 & 39.50 & 35.24 \\
\hline 45.00 & 45.00 & 45.00 & 45.00 & 45.00 & 45.00 & 45.00 & 45.00 & 45.00 & 45.00 & 45.00 & 45.00 \\
\hline
\end{tabular}

Commercial bank rates $2 /$

\begin{tabular}{|c|c|c|c|c|c|c|c|c|c|c|c|c|}
\hline Demand deposits & 7.17 & 6.35 & 6.35 & 6.50 & 6.50 & 6.50 & 7.21 & 7.21 & 6.69 & 6.69 & 8.75 & 8.50 \\
\hline Savings deposits & 21.69 & 25.75 & 27,69 & 27.52 & 27.53 & 27.25 & 27.50 & 27.50 & 27.50 & 27.68 & 27.25 & 24.00 \\
\hline \multicolumn{13}{|l|}{ Time deposits } \\
\hline 3-month & 28.38 & 32.90 & 34.15 & 34.32 & 34.32 & 35.62 & 35.68 & 35.68 & 35.93 & 36.21 & 32.00 & 32.88 \\
\hline 6-month & 29.16 & 31.65 & 33.64 & 33.83 & 33.83 & 35.33 & 35.55 & 35.55 & 35.89 & 36.04 & 36.25 & 34.13 \\
\hline 12-month & 29.77 & 32.40 & 34.91 & 34.92 & 35.00 & 34.79 & 34.92 & 34.92 & 35.04 & 35.00 & 33.75 & 31.25 \\
\hline 24-month & 30.83 & 31.33 & 35.25 & 35.25 & 35.25 & 31.25 & 31.25 & 31.25 & 28.83 & 27.17 & 29.50 & 27.00 \\
\hline Certificates of deposit & 24.46 & 29.89 & 32.46 & 32.30 & 32.30 & 33.10 & 33.10 & 33.10 & 33.50 & 32.60 & 31.00 & 29.25 \\
\hline \multicolumn{13}{|l|}{ Lending rates } \\
\hline Agriculture & 33.65 & 38.66 & 38.65 & 38.96 & 39.50 & 40.73 & 41.52 & 41.52 & 42.22 & 42.22 & 42.00 & 41.75 \\
\hline Export trade & 33.25 & 38.54 & 39.65 & 39.64 & 40.39 & 41.88 & 42.48 & 42.48 & 42.88 & 42.88 & 42.00 & 41.75 \\
\hline Manufacturing & 35.21 & 40.33 & 41.57 & 41.61 & 41.86 & 43.55 & 43.92 & 43.92 & 44.22 & 44.22 & 44.00 & 43.75 \\
\hline Mining and quarrying & 36.30 & 41.01 & 41.60 & 42.17 & 41.83 & 43.23 & 44.07 & 44.07 & 44,39 & 44.39 & 42.00 & 41.75 \\
\hline Construction & 36.52 & 41.58 & 42.06 & 42.41 & 42.52 & 44.36 & 44.70 & 44.70 & 45.00 & 45.00 & 45.25 & 43.75 \\
\hline Other sectors & 36.30 & 41.79 & 42.71 & 43.05 & 43.30 & 45.32 & 45.82 & 45.82 & 46.35 & 46.35 & 46.25 & 45.25 \\
\hline
\end{tabular}

Source: Bank of Ghana.

1/ Discount rates on financial instruments; end-period data.

2) Weighted average of monthly lending and deposit rates. 


$$
-133-
$$

Table 51. Ghana: Balance of Payments, 1990-97

(In millions of U.S. dollars)

\begin{tabular}{|c|c|c|c|c|c|}
\hline & 1993 & 1994 & 1995 & 1996 & 1997 \\
\hline Exports f.o.b. & $1,063.6$ & $1,226.8$ & $1,431,2$ & $1,570.1$ & $1,489.9$ \\
\hline Cocoa & 285.9 & 320.2 & 389.5 & 551.6 & 470.0 \\
\hline Other & 777.7 & 906.6 & $1,041.7$ & $1,045.4$ & $1,019.9$ \\
\hline Imports f.o.b. & $-1,728.0$ & $-1,579.9$ & $-1,687.2$ & $-1,931.0$ & $-2,128.2$ \\
\hline Oil & -153.6 & -171.1 & -191.0 & -253.1 & -233.9 \\
\hline Non-oil & $-1,574,4$ & $-1,408.8$ & $-1,496.2$ & $-1,677.9$ & $-1,894.3$ \\
\hline Trade balance & -664.4 & -353.1 & -256.0 & -360.9 & -638.3 \\
\hline Services (net) & -412.1 & -383.5 & -409.3 & -442.2 & -478.2 \\
\hline Freight and insurance & -123.9 & -106.9 & -116.4 & -99.2 & -151.3 \\
\hline Investment income (net) & -112.3 & -110.9 & -129.8 & -139.7 & -130.1 \\
\hline Other services & -175.9 & -165.7 & -163.1 & -203.3 & -196.8 \\
\hline Unrequited transfers (net) & 517.4 & 471.8 & 523.2 & 481.7 & 519.6 \\
\hline Official & 256.2 & 200.8 & 260.0 & 205.7 & 159.7 \\
\hline Private & 261.2 & 271.0 & 263.2 & 276.1 & 359.9 \\
\hline Current account balance & -559.0 & -265.0 & -142.0 & -321.0 & -594.0 \\
\hline Capital account balance & 630.1 & 478.8 & 432.0 & 279.0 & 540.0 \\
\hline Official capital (net) & 370.2 & 295.3 & 170.0 & 358.0 & 499.0 \\
\hline Long-term loans & 462.8 & 312.1 & 322.3 & 309.3 & 415.7 \\
\hline Inflows & 508.7 & 369.4 & 397.1 & 385.9 & 489.7 \\
\hline Amortization & -45.9 & -57.3 & -74.7 & -76.6 & -74.0 \\
\hline Medium-term loans & -92.6 & -16.8 & -152.0 & 49.0 & 83.7 \\
\hline Inflows & 124.0 & 113.2 & 103.6 & 175.4 & 239.8 \\
\hline Amortization & -216.6 & -130.0 & -256.0 & -127.0 & -156.1 \\
\hline Trust fund & 0.0 & 0.0 & 0.0 & 0.0 & 0.0 \\
\hline Private capital (net) & 106.3 & 205.8 & 259.0 & 70.0 & 92.0 \\
\hline Direct investments & 25.0 & 30.0 & 35.0 & 20.0 & 36.0 \\
\hline Other & 81.3 & 175.8 & 224.0 & 50.0 & 56.0 \\
\hline Short-term capital (net) & 153.6 & -22.3 & 62.4 & -149.0 & -52.0 \\
\hline Errors and omissions & -30.0 & -50.0 & -6.0 & 28.0 & 79.0 \\
\hline Overall balance & 41.2 & 163.8 & 284.0 & -14.0 & 25.0 \\
\hline Financing & -41.2 & -163.8 & -249.1 & 14.0 & -24.9 \\
\hline $\mathrm{IMF}($ net) & -1.5 & -82.8 & -65.3 & -85.6 & -165.7 \\
\hline Payments arrears & 0.0 & 0.0 & 0.0 & 0.0 & 0.0 \\
\hline Bilateral balances & 12.5 & 3.2 & 3.0 & -0.4 & 0.2 \\
\hline Other & -52.2 & .84 .2 & -186.8 & 100.0 & 140.6 \\
\hline
\end{tabular}

Sources: Bank of Ghana; and Fund staff estimates. 
Table 52. Ghana: External Trade Indices, 1990-97

\begin{tabular}{|c|c|c|c|c|c|c|c|c|}
\hline \\
\hline & 1990 & 1991 & 1992 & 1993 & 1994 & 1995 & 1996 & 1997 \\
\hline \multicolumn{9}{|l|}{ Exports } \\
\hline Price index & 90.0 & 88.0 & 83.2 & 73.7 & 84.1 & 97.8 & 95.4 & 91.2 \\
\hline Percentage change & 3.3 & -2.2 & -5.5 & -11.4 & 14.1 & 16.3 & -2.4 & -4.4 \\
\hline Volume index & 157.5 & 179.3 & 187.4 & 228.2 & 230.8 & 231.5 & 260.4 & 258.8 \\
\hline Percentage change & 7.4 & 13.8 & 4.5 & 21.7 & 1.1 & 0.3 & 12.4 & -0.6 \\
\hline Value index & 141.8 & 157.8 & 156.0 & 168.2 & 194.0 & 226.3 & 248.4 & 236.0 \\
\hline Percentage change & 10.9 & 11.2 & -1.2 & 7.8 & 15.3 & 16.6 & 9.8 & -5.0 \\
\hline \multicolumn{9}{|l|}{ Imports } \\
\hline Price index & 126.8 & 124.1 & 127.3 & 127.0 & 140.0 & 151.8 & 152.8 & 148.0 \\
\hline Percentage change & 11.6 & -2.2 & 2.6 & -0.2 & 10.2 & 8.4 & 0.7 & -3.1 \\
\hline Volume index & 141.5 & 158.3 & 170.4 & 202.6 & 168.1 & 165.5 & 188.3 & 214.2 \\
\hline Percentage change & 7.3 & 11.9 & 7.7 & 18.9 & -17.0 & -1.5 & 13.8 & 13.7 \\
\hline Value index & 179.5 & 196.4 & 217.0 & 257.4 & 235.3 & 251.3 & 287.7 & 317.0 \\
\hline Percentage change & 19.8 & 9.4 & 10.5 & 18.6 & -8.6 & 6.8 & 14.5 & 10.2 \\
\hline Terms of trade & 71.0 & 70.9 & 65.4 & 58.0 & 60.0 & 64.4 & 62.5 & 61.6 \\
\hline Percentage change & -7.5 & -0.1 & -7.9 & -11.2 & 3.4 & 7.3 & -3.0 & -1.4 \\
\hline
\end{tabular}

Sources: Data provided by Ghanaian authorities; and Fund staff estimates.

1/ Price and value indices are in terms of U.S. dollars. 
Table 53. Ghana: Value, Volume, and Unit Price of Exports, 1990-97

(In millions of U.S. dollars unless otherwise noted)

\begin{tabular}{|c|c|c|c|c|c|c|c|c|}
\hline & 1990 & 1991 & 1992 & 1993 & 1994 & 1995 & 1996 & 1997 \\
\hline Cocoa beans & 323.8 & 313.4 & 276.8 & 250.5 & 295.0 & 361.1 & 479.6 & 384.8 \\
\hline Volume (metric tons) & 247,380 & 243,040 & 223,774 & 263,665 & 238,269 & 237,262 & 349,067 & 261,251 \\
\hline Unit value (\$/ton) & 1,309 & 1,290 & 1,237 & 950 & 1,238 & 1,522 & 1,375 & 1,473 \\
\hline Cocoa products & 36.8 & 33.1 & 25.6 & 35.4 & 25.2 & 28.4 & 72.2 & 85.2 \\
\hline Volume (metric tons) & 20,756 & 21,745 & 19,328 & 22,839 & 14,050 & 13,864 & 45,382 & 532,656 \\
\hline Unit value (\$/ton) & 1,773 & 1,521 & 1,327 & 1,550 & 1,795 & 2,050 & 1,592 & 1,600 \\
\hline Sheanuts & 1.3 & 0.2 & 0.7 & 1.0 & 0.8 & 0.8 & 4.5 & 6.7 \\
\hline Volume (metric tons) & 4,171 & 600 & 3,115 & 3,444 & 3,000 & 3,000 & 21,467 & 32,018 \\
\hline Value (\$/ton) & 316 & 335 & 212 & 278 & 260 & 260 & 209 & 210 \\
\hline Coffee & 0.6 & 0.4 & 0.9 & 1.0 & 1.2 & 1.2 & 1.4 & 3.6 \\
\hline Volume (metric tons) & 680 & 825 & 1,908 & 1,679 & 2,040 & 2,000 & 869 & 3,144 \\
\hline Unit value (\$/ton) & 853 & 505 & 493 & 590 & 602 & 602 & 1,631 & 1,145 \\
\hline Timber and timber products & 118.0 & 124.2 & 113.9 & 147.4 & 165.4 & 190.6 & 146.9 & 172.0 \\
\hline Volume (cubic meters) & 370,000 & 393,598 & 406,662 & 727,813 & 780,000 & 590,000 & 364,771 & 442,017 \\
\hline Unit value ( $\$ / \mathrm{cu}$. meter) & 319 & 316 & 280 & 203 & 212 & 323 & 402.6 & 389.1 \\
\hline Gold & 201.7 & 304.4 & 343.4 & 434.0 & 548.6 & 647.2 & 612.4 & 579.2 \\
\hline Volume (fine ounces) & 526,361 & 834,986 & 995,377 & $1,210,473$ & $1,435,415$ & $1,689,470$ & $1,584,378 \quad 1$ & $1,747,018$ \\
\hline Unit value (\$/ounce) & 383 & 365 & 345 & 358 & 382 & 383 & 386.5 & 331.5 \\
\hline Diamonds & 16.5 & 19.2 & 19.3 & 17.3 & 20.4 & 14.8 & 13.4 & 11.4 \\
\hline Volume (carats) & 636,371 & 663,390 & 690,408 & 552,854 & 717,419 & 645,100 & 634,192 & 562,651 \\
\hline Unit value (\$/carat) & 26 & 29 & 28 & 31 & 28 & 23 & 21.2 & 20.2 \\
\hline Bauxite & 10.0 & 8.6 & 9.5 & 8.4 & 9.5 & 10.4 & 8.5 & 10.8 \\
\hline Volume (metric tons) & 368,629 & 320,313 & 399,155 & 364,642 & 451,802 & 526,335 & 383,612 & 536,732 \\
\hline Unit value $(\$ /$ ton) & 27 & 27 & 24 & 23 & 21 & 20 & 22.1 & 20.1 \\
\hline Manganese & 14.2 & 20.2 & 16.4 & 13.9 & 9.6 & 6.4 & 7.1 & 11.6 \\
\hline Volume (metric tons) & 255,310 & 281,195 & 285,055 & 309,122 & 245,256 & 200,000 & 229,227 & 355,232 \\
\hline Unit value (\$/ton) & 56 & 72 & 58 & 45 & 39 & 32 & 31.1 & 32.5 \\
\hline Residual oil & 28.6 & 19.7 & 19.2 & 14.2 & 17.7 & 17.3 & 22.1 & $\ldots$ \\
\hline Volume (metric tons) & 227,472 & 205,442 & 187,930 & 140,588 & 194,068 & 156,007 & 196,100 & $\ldots$ \\
\hline Unit value (\$/ton) & 126 & 96 & 102 & 101 & 91 & 111.2 & 112.8 & ... \\
\hline Electricity & 88.5 & 96.0 & 95.6 & 69.1 & 56.4 & 53.1 & 58.2 & 67.6 \\
\hline Volume (million KWH) & 3,556 & 3,610 & 3,763 & 3,236 & 2,712 & 2,456 & 2,573 & 2,887 \\
\hline Unit value $(\$ / 000 \mathrm{KWH})$ & 25 & 27 & 25 & 21 & 21 & 22 & 23 & 23.4 \\
\hline Other & 56.7 & 58.1 & 64.9 & 71.7 & 77.0 & 100.0 & 144.0 & 157.1 \\
\hline
\end{tabular}

Source: Bank of Ghana. 
Table 54. Ghana: Direction of Trade, 1991-97 (In percent)

\begin{tabular}{|c|c|c|c|c|c|c|c|c|c|c|c|c|c|c|}
\hline & \multicolumn{7}{|c|}{ Exports } & \multicolumn{7}{|c|}{ Imports } \\
\hline & 1991 & 1992 & 1993 & 1994 & 1995 & 1996 & 1997 & 1991 & 1992 & 1993 & 1994 & 1995 & 1996 & 1997 \\
\hline Industrial countries & 92.4 & 77.4 & 71.0 & 72.4 & 71.2 & 68.2 & 64.0 & 84.0 & 64.6 & 61.4 & 59.5 & 57.5 & 61.5 & 59.8 \\
\hline France & 1.0 & 1.6 & 5.1 & 5.8 & 7.8 & 7.5 & 6.7 & 1.2 & 3.1 & 4.8 & 3.6 & 3.5 & 4.0 & 4.9 \\
\hline \multicolumn{15}{|l|}{ Germany, Federal } \\
\hline Republic of & 45.2 & 6.5 & 15.7 & 14.8 & 11.9 & 9.1 & 9.2 & 5.5 & 9.0 & 5.7 & 5.6 & 7.6 & 5.4 & 6.0 \\
\hline Italy & 0.6 & 1.5 & 3.2 & 5.2 & 3.6 & 8.5 & 3.0 & 1.4 & 5.9 & 2.9 & 8.0 & 3.5 & 7.2 & 3.8 \\
\hline Japan & 3.2 & 1.8 & 4.6 & 3.8 & 4.0 & 3.9 & 4.5 & 3.7 & 6.6 & 4.0 & 6.8 & 4.0 & 3.4 & 2.6 \\
\hline Netherlands & 16.4 & 4.8 & 3.7 & 4.7 & 3.4 & 2.5 & 7.4 & 47.2 & 3.2 & 4.5 & 4.1 & 5.0 & 3.0 & 3.9 \\
\hline United Kingdom & 17.7 & 9.6 & 8.6 & 13.0 & 14.6 & 15.8 & 11.7 & 11.9 & 17.2 & 17.4 & 15.8 & 16.4 & 16.3 & 15.2 \\
\hline United States & 1.3 & 2.6 & 17.5 & 12.6 & 11.4 & 9.6 & 8.4 & 8.2 & 10.2 & 11.6 & 6.7 & 6.8 & 10.2 & 10.5 \\
\hline Other & 7.0 & 49.1 & 12.7 & 12.4 & 14.5 & 11.2 & 13.1 & 4.9 & 9.3 & 10.5 & 9.0 & 10.6 & 12.0 & 12.9 \\
\hline Other European & 0.6 & 1.5 & 1.0 & 1.3 & 2.1 & 2.5 & 3.8 & 1.2 & 1.6 & 0.2 & 1.1 & 1.1 & 1.1 & 1.3 \\
\hline Rest of the world & 7.0 & 21.2 & 28.1 & 26.3 & 26.7 & 29.3 & 32.2 & 14.9 & 33.8 & 38.4 & 39.3 & 41.4 & 37.5 & 38.9 \\
\hline
\end{tabular}

Source: IMF, Direction of Trade Statistics Yearbook. 1997. 
Table 55. Ghana: Services and Transfers Account, 1992-97

(In millions of U.S. dollars)

\begin{tabular}{|c|c|c|c|c|c|c|c|c|c|c|}
\hline & \multicolumn{2}{|c|}{1993} & \multicolumn{2}{|c|}{1994} & \multicolumn{2}{|c|}{1995} & \multicolumn{2}{|c|}{1996} & \multicolumn{2}{|c|}{1997} \\
\hline & Credit & Debit & Credit & Debit & Credit & Debit & Credit & Debit & Credit & Debit \\
\hline Total services and transfers & 688.3 & -582.9 & 646.6 & -558.3 & 703.2 & -588.9 & 678.2 & -638.6 & 721.2 & -679.8 \\
\hline Total services & 156.3 & -568.3 & 159.3 & -542.8 & 164.3 & -573.2 & 180.3 & -622.4 & 191.6 & -669.8 \\
\hline Freight and merchandise insurance & 36.4 & -160.3 & 37.1 & -144.0 & 37.9 & -154.0 & 39.6 & 187.6 & 41.3 & -193.2 \\
\hline Other transportation & 45.9 & -68.3 & 46.8 & -69.7 & 47.8 & -71.1 & 48.1 & -74.2 & 50.2 & -77.6 \\
\hline Travel & 10.6 & -19.7 & 10.8 & -20.1 & 11.0 & -20.5 & 12.7 & -22.4 & 14.6 & -23.4 \\
\hline Investment income & 11.6 & -123.9 & 11.8 & -122.7 & 13.7 & -143.5 & 23.5 & -163.1 & 267 & -158.1 \\
\hline IMF charges & 0.0 & -17.8 & 0.0 & -14.8 & 0.0 & -11.1 & 0.0 & -7.2 & 0.0 & -5.1 \\
\hline Interest medium term loans & 0.0 & -26.9 & 0.0 & -30.7 & 0.0 & -39.7 & 0.0 & -45.8 & 0.0 & 49.5 \\
\hline Interest long term loans & 0.0 & -60.1 & 0.0 & -59.0 & 0.0 & -71.6 & 0.0 & -72.6 & 0.0 & -67.7 \\
\hline Other official interest payments & 0.0 & -8.2 & 0.0 & -2.8 & 0.0 & -1.3 & 0.0 & -7.0 & 0.0 & -4.1 \\
\hline Private suppliers' credits & 0.0 & 0.0 & 0.0 & 0.0 & 0.0 & 0.0 & 0.0 & 0.0 & 0.0 & 0.0 \\
\hline Banking loans & 0.0 & -1.7 & 0.0 & -4.8 & 0.0 & -9.2 & 0.0 & -18.6 & 0.0 & -17.8 \\
\hline Profit and dividends & 0.0 & -9.2 & 0.0 & -10.6 & 0.0 & -10.6 & 0.0 & -11.7 & 0.0 & -12.7 \\
\hline Government (n.i.e.) & 11.3 & -113.3 & 11.5 & -101.8 & 11.8 & -98.7 & 12.4 & -92.8 & 13,0 & -117.0 \\
\hline Other services & 40.5 & -82.8 & 41.3 & -84.5 & 42.1 & -86.1 & 44.0 & -93.9 & 45.8 & -99.1 \\
\hline Total transfers & 532.0 & -14.6 & 487.3 & -15.5 & 538.9 & -15.7 & 497.9 & -16.2 & 529.6 & -10.0 \\
\hline Official & 265.3 & -9.1 & 210.8 & -10.0 & 270.0 & -10.0 & 215.6 & $-10,0$ & 169.7 & -10.0 \\
\hline Private & 266.7 & -5.5 & 276.5 & -5.5 & 268.9 & -5.7 & 282.3 & -6.2 & 359.9 & 0.0 \\
\hline
\end{tabular}

Sources: Bank of Ghana; and Fund staff estimates. 
Table 56. Ghana: Clearing Accounts Under Bilateral Payments Agreements, June 1992-December 1997

\begin{tabular}{|c|c|c|c|c|c|c|c|c|c|c|c|c|c|}
\hline & \multicolumn{2}{|c|}{1992} & & \multicolumn{2}{|c|}{1993} & \multicolumn{2}{|c|}{1994} & \multicolumn{2}{|c|}{1995} & \multicolumn{2}{|c|}{1996} & \multicolumn{2}{|c|}{1997} \\
\hline & June & Dec. & 1/ & June & Dec. & June & Dec. & June & Dec. & June & Dec. & June & Dec. \\
\hline \multicolumn{14}{|l|}{ Active account (millions } \\
\hline of U.S. dollars) $2 /$ & 38.6 & 33.1 & & 25.8 & 20.8 & 17.5 & 17.5 & 26 & 14.6 & 14.6 & 14.9 & 14.9 & 14.8 \\
\hline Bulgaria & 8.6 & 8.6 & & 8.6 & 8.6 & 8.6 & 8.6 & 8.6 & 8.6 & 8.6 & 8.6 & 8.6 & 8.6 \\
\hline China & 0.6 & 0 & & 0 & 0 & 0 & 0 & 0 & 0 & $\mathbf{0}$ & 0 & 0 & 0 \\
\hline Cuba & 21.9 & 17.3 & & 12.9 & 8.5 & 5.3 & 5.5 & 5.5 & 5.4 & 5.4 & 5.7 & 5.7 & 5.6 \\
\hline German Dem. Rep. 3/ & -8.5 & -8.5 & & -8.5 & -8.5 & -8.5 & -8.5 & 0 & 0 & 0 & 0 & 0 & 0 \\
\hline Romania & 10.1 & 10.3 & & 11.4 & 11.4 & 11.3 & 11.3 & 11.3 & 0 & 0 & 0 & 0 & 0 \\
\hline Yugoslavia & 0.7 & 0.8 & & 0.6 & 0.6 & 0.6 & 0.4 & 0.4 & 0.4 & 0.4 & 0.4 & 0.4 & 0.4 \\
\hline Poland & 0 & 0 & & 0 & 0 & 0 & 0 & 0 & 0 & 0 & 0 & 0 & 0 \\
\hline U.S.S.R. & 0.1 & 0.1 & & 0.1 & 0.1 & 0.1 & 0.1 & 0.1 & 0.1 & 0.1 & 0.1 & 0.1 & 0.1 \\
\hline Czechoslovakia & 0.8 & 0.8 & & 0.4 & 0 & 0 & 0 & 0 & 0 & 0 & 0 & 0 & 0 \\
\hline Hungary & 1.6 & 0.7 & & 0.3 & 0.1 & 0.1 & 0.1 & 0.1 & 0.1 & 0.1 & 0.1 & 0.1 & 0.1 \\
\hline \multicolumn{14}{|l|}{ Inactive accounts (millions } \\
\hline of cedis) $4 /$ & 191.7 & 191.7 & & 191.7 & 191.7 & 191.7 & 191.7 & 191.7 & 191.7 & 191.7 & 191.7 & 191.7 & 191.7 \\
\hline China & 38.7 & 38.7 & & 38.7 & 38.7 & 38.7 & 38.7 & 38.7 & 38.7 & 38.7 & 38.7 & 38.7 & 38.7 \\
\hline Egypt & 0.9 & 0.9 & & 0.9 & 0.9 & 0.9 & 0.9 & 0.9 & 0.9 & 0.9 & 0.9 & 0.9 & 0.9 \\
\hline Others & 152.1 & 152.1 & & 152.1 & 152.1 & 152.1 & 152.1 & 152.1 & 152.1 & 152.1 & 152.1 & 152.1 & 152.1 \\
\hline
\end{tabular}

Source: Ghanaian authorities.

1/ Revised position after GDR account reconciliation.

2/ Minus (positive) sign indicates net debit (credit) position of Ghana.

3/ The GDR accounts were reconciled in 1992, taking effect from December 1991. The 1992 flow, therefore, used the revised 1991 December position for consistency with end-1992 position. Similalrly, the 1991 flow takes into account the unreconciled position of December 1991 compared with December 1990.

4/ The changes are mainly due to exchange rate fluctuations. 
Table 57. Ghana: External Public Debt and Debt Service, 1991-97 (In millions of U.S. dollars)

\begin{tabular}{lrrrrr}
\hline & 1993 & 1994 & 1995 & 1996 & 1997 \\
\hline & & & & & \\
Long and medium-term debt 1/ & $4,508.30$ & $4,841.30$ & $5,035.60$ & $5,597.70$ & $6,156.30$ \\
Bilateral loans & $1,292.70$ & $1,302.00$ & $1,399.60$ & $1,483.70$ & $1,655.00$ \\
Multilateral loans & $3,215.60$ & $3,539.30$ & $3,636.00$ & $4,114.00$ & $4,501.30$ \\
& & & & & \\
IMF & 738.00 & 686.90 & 661.80 & 547.90 & 353.60 \\
Ofwhich: & & & & & \\
Tranche Policies/CFF & 159.40 & 127.40 & 115.10 & 85.70 & 33.80 \\
Trust Fund/SAF/ESAF & 578.70 & 559.60 & 546.70 & 462.20 & 319.80 \\
Short-term loans 2/ & 197.00 & 175.00 & 178.00 & 28.00 & 40.00 \\
Total external debt & $5,443.50$ & $5,703.10$ & $5,874.90$ & $6,173.90$ & $6,549.90$ \\
& & & & & \\
Debt service payments & & & & & \\
Principal & 329.10 & 270.10 & 438.20 & 328.40 & 396.00 \\
Medium term & 216.60 & 130.00 & 255.50 & 126.50 & 156.00 \\
Long term & 45.90 & 57.30 & 74.70 & 76.60 & 74.00 \\
IMF repurchases & 66.60 & 82.80 & 108.00 & 125.30 & 165.70 \\
Interest & 102.70 & 105.90 & 127.80 & 144.30 & 140.00 \\
Medium-term & 28.60 & 35.50 & 45.10 & 61.10 & 65.00 \\
Long-term & 60.10 & 59.00 & 71.60 & 72.60 & 68.00 \\
IMF charges 3/ & 14.00 & 11.40 & 11.10 & 10.60 & 7.00 \\
Total & & & & & \\
Including IMF & 431.80 & 376.00 & 566.00 & 472.70 & 536.00 \\
Excluding IMF & 351.20 & 281.80 & 446.90 & 336.80 & 363.30 \\
\hline ( & & & & &
\end{tabular}

Sources: Data provided by the Ghanaian authorities; and staff estimates.

1/ Including medium-term debt owed by the Bank of Ghana to foreign commercial banks.

2/ Consists of short-term oil credits, Cocoa Board debt, and Bank of Ghana debt.

3/ Excluding SDR charges. 
Table 58. Ghana: Classification of Subvented Agencies

\section{Category 1}

1.

2.

3.

4.

5.

6.

7.

8.

9.

10.

11.

12.

13.

14.

15.

16.

17.

18.

19.

20.

21.

22.

23.

24.

25 .

26.

27.

28.

29.

30.

31.

32.

33.

34.

35 .

36.

37.
To be wholly subvented

Forestry Commission

Ghana Airways Authority

National Council for Tertiary Education

Immigration Service

Prisons Service

Fire Service

Police Service

Serious Fraud Service

General Legal Council

Law Reform Commission

Council for Law Reporting

Prices and Incomes Board

National Population Council

Statistical Service

Fisheries Commission

Ghana Veterinary Council

Environmental Protection Agency

National Accreditation Board

National Board of Prof. And Tech.

Examination

Divestiture Implementation Committee

Customs Excise and Preventive Service

Internal Revenue Service

Land Commission

Minerals Commission

National Commission on Children

NCWD

Ghana FAO Representative

National Raod Safety

Commission of Human Rights

National Electoral Commission

National Commission on Culture

National Commission for Civic Education

National Service Secretariat

Narcotics Control Board

Public Tribunals

Legal Aid Board 
Table 58. Ghana: Classification of Subvented Agencies (continued)

\section{Category 2}

1.

2.

3.

4.

5.

6.

7.

8.

9.

10.

11.

12.

13.

14.

15.

16.

17.

18.

19.

20.

21.

22.

23.

24.

25.

26.

27 .

28.

29.

30.

31 .

32.

33.

34.

35.

36.

37.

38.

39.

40.
To be partially subvented

Grains and Legumes Development Board

Irrigation Development Authority

Forestry Research Institute

Ghana Export Promotion Council

Ghana Tourist Board

Ghana Standards Board

NBSSI

Secretariat (CSIR)

Crops Research Institute

Animal Research Institute

Soil Research Institute

Soil Research Centre

Building and Roads Research Institute

Food Research Institute

Institute of Aquatic Biology

Industrial Research Institute

Water Resources Research Institute

Oil Palm Research Institute

Scientific Instrumentation Centre

Nyakpala Agricultural Research Institute

Ghana Grains Development Project

Technology Transfer Centre

Plant Genetic Research

Government Technical Training Centre

Ghana Library Board

University of Ghana

University of Science and Technology

School of Administration

University of Cape Coast

Institute of African Studies

Institute of Stat. Soc. Econ-Res. (ISSR)

Institute of Adult Education

College of Arts UST

University of Ghana Medical School

Volta Basin Research Institute

University Research Stations

Regional Institute Population Studies

School of Medical Science (UST)

School of Agriculture (Cape Coast)

Ministry of Energy - Technical Division 
Table 58. Ghana: Classification of Subvented Agencies (continued)

Categroy 2

41.

42.

43.

44.

45.

46.

47.

48.

49.

50 .

51.

52.

53.

54.

55.

56.

57.

58.

59.

60.

61.

62.

63.

64.

65.

66.

67.

68.

69.

70.

71.

72.

73.

74.

75 .

76.

77.

78.

79.

80.
To be partially subvented (continued)

State Enterprises Commission

Boadi Cattle Project (UST)

Noguchi Memorial Institute

Technical Cons. Centre (UST)

Ghana Research Appr. Tech. Ind. Sch. (GRATIS)

Science Technology Policy Research Institute

Accra Polytechnic

Cape Coast Polytechnic

Takoradi Polytechnic

Kumasi Polytechnic

Tamale Polytechnic

Distance Education

University College of Education

St. John's Ambulance Brigade

Scientific Research into Plant Medicine

Jachie Training Centre

Jirapa Orphanage

Abor Research Centre

Ghana National Comm. - Local (UNESCO)

West African Examinations Council - Local

West African Examinations Council - International

Ghana National Commission - UNESCO (International)

School of Engineering (UST)

Institute of Renewable Natural Resources (UST)

School of Performing Arts

Ghana Institute of Languages

Institute of Professional Studies

University of Development Studies

University of Ghana (London)

Dental School

National Sports Council

National Youth Organising Committee

National Sports College (Winneba)

Pharmacy Board

Medical and Dental Council

Christian Health Association

MDPI

National Vocational Training School

School of Social Work

Ashanti Mampong Babies Home 
Table 58. Ghana: Classification of Subvented Agencies (continued)

\section{Category 2}

81.

82.

83.

84.

85 .

86.

87.

88.

89.

90.

91.

92.

93.

94.

95.

96.

97.

98.

99.

100.

\section{Category 3}

1.

2.

3.

4.

5.

6.

7.

8.

9.

10.

11.

12.

\section{Category 4}

1.

2.

3.
To be partially subvented (continued)

GIMPA

Ghana Atomic Energy Commission

Ghana News Agency

Ghana Institute of Journalism

National Film and TV Institute

Legon Centre for Inst. Affairs

Veterans Association of Ghana

Ghana Armed Forces Staff College

National Symphony Orchestra

Abibigroma

Museums and Monuments

Ghana Dance Ensemble

W.E.B. de Bois Memorial Centre

Kwame Mkrumah National Park

School of Communication Studies

Ghana Investment Centre

School of Mines - Kumasi

School of Mines - Tarkwa

Nurses and Midwives Council

Regional Maritime Academy

To be commercialized

Ghana Railway Corporation

Ghana University Press

Institute of Chartered Accountant

International Students Hostel

Land Valuation Board

HOTCAT

Land Title Registry

Ghana Broadcasting Corporation

Ghana News Agency (Ghana)

Ghana News Agency (London)

National Theatre

Ghana Dance Ensemble

To be closed down or privatized

Development and Application Intermediate Technology

Ghana National ATLAS Project

Ghana National Science and Technology 
Table 58. Ghana: Classification of Subvented Agencies (concluded)

\section{Category 4}

4.

5.

6.

7.

8.

9.

10.

11.

12.

13.

14.

15.

16.

17.

18.

19.

20.

21.

22.

23.

24.

25.
To be closed down or commercialized (continued)

Public Servant Housing Loans Board

Technical Services Centre

National Teacher Training Council

Institute for Educational Plan and Administration

Education Commission

Integrated Commission for Centres Employment Skills

Ghana Science Education

Ghana Academy of Arts and Science

Encyclopedia Africana Project

Organisation of Trade Union Unity

Opportunities Industrialisation Centre

Ghana Co-operative Council

Ghana Co-operative College

Local Government Training School

National Association of Local Authorities

Armed Forces Sports Control Board

Pan African Writers Association

All African Students Union

Ghana Book Development Council

Confiscated Assets Committee

Armed Forces School

National Revenue Secretariat 